University of Louisville ThinkIR: The University of Louisville's Institutional Repository

Electronic Theses and Dissertations

$5-2016$

\title{
"Puritan hypocrisy" and "conservative Catholicity" : how Roman Catholic clergy in the border states interpreted the U.S. Civil War.
}

Carl C. Creason

University of Louisville

Follow this and additional works at: https://ir.library.louisville.edu/etd

Part of the Catholic Studies Commons, $\underline{\text { Cultural History Commons, History of Religion }}$ Commons, Intellectual History Commons, Religious Thought, Theology and Philosophy of Religion Commons, and the United States History Commons

\section{Recommended Citation}

Creason, Carl C., "'Puritan hypocrisy" and "conservative Catholicity" : how Roman Catholic clergy in the border states interpreted the U.S. Civil War." (2016). Electronic Theses and Dissertations. Paper 2430.

https://doi.org/10.18297/etd/2430

This Master's Thesis is brought to you for free and open access by ThinkIR: The University of Louisville's Institutional Repository. It has been accepted for inclusion in Electronic Theses and Dissertations by an authorized administrator of ThinkIR: The University of Louisville's Institutional Repository. This title appears here courtesy of the author, who has retained all other copyrights. For more information, please contact thinkir@louisville.edu. 
"PURITAN HYPOCRISY" AND “CONSERVATIVE CATHOLICITY": HOW ROMAN CATHOLIC CLERGY IN THE BORDER STATES INTERPRETED THE U.S. CIVIL WAR

\author{
By \\ Carl C. Creason \\ B.A., Murray State University, 2011

\begin{abstract}
A Thesis
Submitted to the Faculty of the

College of Arts and Sciences of the University of Louisville

in Partial Fulfillment of the Requirements

for the Degree of
\end{abstract} \\ Master of Arts \\ in History \\ Department of History \\ University of Louisville \\ Louisville, Kentucky
}

May 2016 
Copyright 2016 by Carl C. Creason

All rights reserved 



\title{
"PURITAN HYPOCRISY" AND "CONSERVATIVE CATHOLICITY": HOW ROMAN CATHOLIC CLERGY IN THE BORDER STATES INTERPRETED THE U.S. CIVIL WAR
}

\author{
By \\ Carl C. Creason \\ B.A., Murray State University, 2011 \\ A Thesis Approved on
}

April 14, 2016

by the following Thesis Committee:

Dr. Thomas C. Mackey

Dr. A. Glenn Crothers

Dr. Jasmine Farrier 


\section{DEDICATION}

This thesis is dedicated to my grandmother,

$$
\text { Mrs. Nina Letanosky (1941-2013), }
$$

a fellow bookworm, student of history, unbelievable cook, and best friend. 


\section{ACKNOWLEDGEMENTS}

As many historians have noted, no piece of scholarship constitutes the work of a single individual. Having read many acknowledgement sections during my undergraduate and graduate careers, I finally have the opportunity to write my own and thank everyone who has helped me achieve my academic goals. Although graduate students spend much of their time alone writing in an empty apartment, reading in a silent nook in the library, or researching at an archives, they rely on advisors, friends, and family for guidance, support, and an escape from the intellectual grind. While earning my M.A. in United States History at the University of Louisville, Dr. Thomas C. Mackey remained the ideal advisor. Always in his office or at the computer responding to emails, Dr. Mackey never hesitated to answer questions, read drafts of my work, write recommendation letters for scholarships, or to chat about history, historiography, the academy, politics, or life after graduate school. I owe Dr. Mackey my sincerest gratitude for guiding me through the process of writing this thesis and for improving its arguments and prose along the way. In addition to Dr. Mackey, I thank Dr. A. Glenn Crothers for encouraging me to pursue the topic and for agreeing to serve as the second reader on my thesis committee. Dr. Jasmine Farrier also deserves recognition for serving as the third reader and for agreeing to join the committee late during the semester.

I also want to thank other members of the University of Louisville Department of History, especially those who served on the Graduate Committee and awarded me a Graduate Teaching Assistantship during the 2014-2015 and 2015-2016 academic years. 
The GTA position afforded me the opportunity to gain post-secondary teaching experience as well as provided a generous stipend that allowed me to focus on research and writing. Furthermore, I want to recognize Drs. Malissa Taylor and John McLeod, both of whom accepted me as a teaching assistant and served as valuable mentors. As I have learned during the final weeks of my graduate career, the reading, research, and writing components of the M.A. degree often constitute the "easy parts" of the process. Completing paperwork, organizing committees and defense dates, and formatting the thesis to the required style have produced several "hiccups and headaches." Fortunately for me and my classmates, Dr. Daniel Krebs, Director of Graduate Studies, and Lee Keeling, Senior Program Assistant, offered timely and invaluable assistance throughout the process. In fact, I doubt any department has a more efficient and accommodating administrative duo than the Department of History. Robin Carroll and Lee Keeling have been remarkable in helping me allocate funding for research trips and ensuring that I adhered to all required deadlines during the last two years. I also thank Lee for her "motherly" attributes and regular treats. In addition to the faculty and staff in the department, members of my cohort—especially Hannah O'Daniel[s], Benjamin Gies, and Eric Brumfield — helped make my experience worthwhile and enjoyable. Together we learned much about history and historiography, engaged in thought-provoking political discussions, and shared an inordinate number of laughs but not enough beers.

I would not have succeeded at the University of Louisville without the guidance and tutelage I received while earning my B.A. in History at Murray State University. Drs. Duane Bolin and James Humphreys, and Mr. Ted F. Belue have and continue to be great friends, teachers, and mentors. In particular, Dr. Humphreys encouraged me to 
pursue graduate studies in History, seek publication opportunities, and present papers at academic conferences. I thank him for his guidance and for helping me "build a C.V." before beginning graduate work. In writing this thesis, I have relied on several professionals outside of the academy, particularly staff members at The Filson Historical Society, the Kentucky Historical Society, the University of Notre Dame Archives, and the Associated Archives at St. Mary's Seminary and University in Baltimore, Maryland. I extend a special token of gratitude to Joe Smith (UNDA) and Alison Foley (AAB) for all the copies and scans of documents. Furthermore, I want to thank the staff of University of Louisville's Ekstrom Library, especially the ILL Department, and Rena Schergen, Archivist at the Archdiocese of St. Louis, for arranging a special loan integral to this thesis.

Finally, I want to recognize those who have offered me the most support during my academic career. I can state without equivocation that I could not have earned my undergraduate or graduate degrees without the sacrifices made by my mother, Janet Creason. She has been a constant source of love, encouragement, and support throughout my life, and I cannot thank her enough. I love you, mom. Furthermore, my sister, Courtney Creason, has always supported my goals in higher education and provided an important escape from academics to discuss college sports. Undoubtedly the most important male role model in my life, my grandfather, Louis Letanosky, instilled in me the importance of hard work and family loyalty. This thesis is dedicated to his late wife and my grandmother, Nina Letanosky, who nurtured my interest in history, taught me important life lessons, and kept my stomach filled with delicious meals during the formative years of my life. As of April 15, 2016, Kellie Money and I have been in a 
relationship for five years. After meeting during our undergraduate careers at Murray State, we have remained study-buddies, travel companions, fellow foodies, and best friends. I have learned much from her and have become a better student and person due to her presence in my life. I look forward to our future together and to nailing our shoes to "The Shoe Tree" in Murray. I also want to thank her immediate family-Lee, Linda, and Elizabeth—who accepted me into their home as a "son" and "brother."

As a final point, all errors, mistakes, and omissions are my own; however, I hope there are not many. 


\section{ABSTRACT \\ "PURITAN HYPOCRISY” AND “CONSERVATIVE CATHOLICITY": HOW ROMAN CATHOLIC CLERGY IN THE BORDER STATES INTERPRETED THE U.S. CIVIL WAR \\ Carl C. Creason}

April 14, 2016

This thesis analyzes how Roman Catholic clergy in the Border States-Missouri, Kentucky, and Maryland - interpreted the United States Civil War. Overall, it argues that prelates and priests from the region viewed the war through a religious lens informed by their Catholic worldview. Influenced by their experiences with anti-Catholicism and nativism as well as the arguments of the Catholic apologist movement, the clergy interpreted the war as a product of the ill-effects of Protestantism in the country. In response, the clergy argued that if more Americans had practiced Catholicism then the war could and would have been avoided. Furthermore, this thesis illustrates how the interconnectedness of the anti-Catholic and antislavery movements shaped the clergy's interpretations of the war and the political parties of the era. By analyzing how the clergy responded to the election of 1860 , the secession crisis, the debate over slavery, and civil liberties disputes during the war, this thesis underscores the clergy's belief that Protestantism created fanatical leaders, sectional division, and national instability, while Catholicism preserved law, order, and morality in society. 


\section{TABLE OF CONTENTS}

PAGE

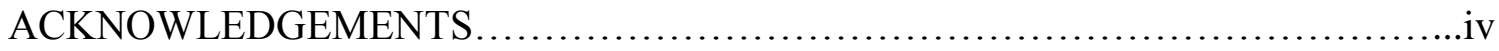

ABSTRACT .....................................................................viii

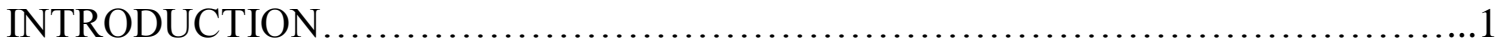

CHAPTER I

A Historiographical Review of American Catholicism during the Civil War

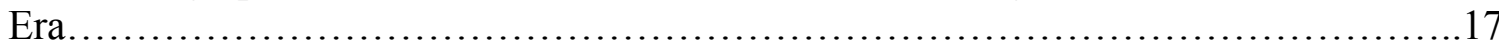

CHAPTER II

An Era of Anti-Catholics and Apologists: Setting the Stage for a Religious Interpretation of the Civil War...................................................................

\section{CHAPTER III}

"The whole world seems to be getting out of joint": The Catholic Response to the Election of 1860, the Secession Movement, and the Start of the Civil War in the Border

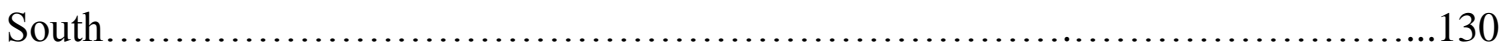

\section{CHAPTER IV}

"Such is the state of things, nothing should be attempted against the laws": Border State

Clergy and the Debate Over Slavery, Abolitionism, and Wartime Emancipation.

\section{CHAPTER V}

The "obvious infringement of religious liberty": Roman Catholic Understandings of the Separation of Church and State in the Civil War Border South.........................236

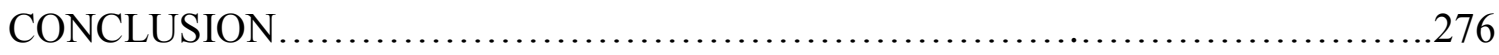

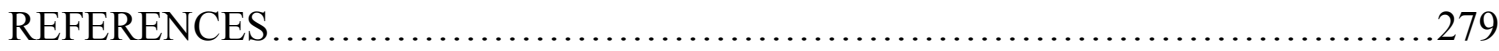

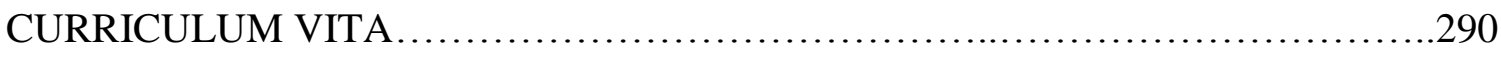




\section{INTRODUCTION}

Writing in his diocesan journal on the first day of January 1863, Bishop Martin John Spalding offered his assessment of the Emancipation Proclamation. A Roman Catholic cleric from Louisville, Kentucky, Spalding wrote the following about President Abraham Lincoln's executive order:

While our brethren are thus slaughtered in hecatombs, Ab. Lincoln cooly issues his Emancipation Proclamation, letting loose from three to four millions of halfcivilized Africans to murder their Masters \& Mistresses! And all this under the pretense of philanthropy! ${ }^{1}$

Spalding's statements mirrored the opinions of most white Kentuckians, Unionists in the

Border States, ${ }^{2}$ northern Democrats, and residents of the South at the time. Slaveholding interests and, more importantly, a dedication to safeguarding the antebellum racial order of white supremacy led most Americans- except for northern Republicans and some Union soldiers - to denounce Lincoln's proclamation. During the first two years of the Civil War, many whites in the North and Border States, regardless of party affiliation,

${ }^{1}$ Journal of Martin John Spalding, Bishop of Louisville, April 8, 1860-March 27, 1864 (transcript), Box 10, Folder 9, Archdiocese of Louisville Records (hereafter CDBL), University of Notre Dame Archives, Notre Dame, IN (hereafter UNDA), January 1, 1863, p. 44. Peter E. Hogan transcribed the journal in April 1950 and provided a copy to the University of Notre Dame Archives. The original diocesan journal is located in the Department of Archives and Manuscripts, Mullen Memorial Library, Catholic University of America, Washington, DC. The transcript will be cited hereafter as (Spalding Journal, CDBL, UNDA).

2 This thesis will employ interchangeably the terms "Border States" and "Border South" in reference to the region comprised of the states of Missouri, Kentucky, and Maryland. 
supported a war for the restoration of the Union. However, to these individuals, the issuance of the Emancipation Proclamation meant that the Lincoln administration had transformed the war into a contest that would not only suppress the Confederate rebellion but also end slavery, thereby disrupting the antebellum status quo. ${ }^{3}$

Therefore, the first two lines of Spalding's polemic indicate that the bishop concurred with the opinions of other Lincoln opponents, noting that the Emancipation Proclamation would foment lawlessness and lead to a race war between whites and blacks in the South. As a Catholic slaveholding bishop born and reared in Kentucky, Spalding's entry suggests that he espoused the attitudes, anxieties, and value judgements of most white southerners in nineteenth-century America. However, the remaining lines in his passage illustrate how Spalding's interpretation of the document involved much more than just concerns about slaveholding, the racial order of the South, or violence in

\footnotetext{
${ }^{3}$ For a general history of the social and political context of the Civil War era, see: James M. McPherson, Battle Cry of Freedom: The Civil War Era (New York: Oxford University Press, 1988). For more information about the impact of and reaction to the issuance of the Emancipation Proclamation, see: Allen C. Guelzo, Lincoln's Emancipation Proclamation: The End of Slavery in America (New York: Simon \& Schuster, 2004); Eric Foner, The Fiery Trial: Abraham Lincoln and American Slavery (New York: W. W. Norton, 2010), 206-289; Louis P. Masur, Lincoln's Hundred Days: The Emancipation Proclamation and the War for the Union (Cambridge, MA: The Belknap Press of Harvard University Press, 2012). For more information about the course of the Civil War in the Border States or Border South, see: William W. Freehling, The South vs. The South: How Anti-Confederate Southerners Shaped the Course of the Civil War (New York: Oxford University Press, 2001); Anne E. Marshall, Creating a Confederate Kentucky: The Lost Cause and Civil War Memory in a Border State (Chapel Hill: The University of North Carolina Press, 2010); William C. Harris, Lincoln and the Border States: Preserving the Union (Lawrence: University Press of Kansas, 2011); Aaron Astor, Rebels on the Border: Civil War, Emancipation, and the Reconstruction of Kentucky and Missouri (Baton Rouge: Louisiana State University Press, 2012); Christopher Phillips, The Civil War in the Border South (Santa Barbara, CA: Praeger, 2013); Gary R. Matthews, More American than Southern: Kentucky, Slavery, and the War for an American Ideology, 1828-1861 (Knoxville: The University of Tennessee Press, 2014).
} 
the region. In fact, the bishop's arguments in the second half of his entry differentiate him from the majority of wartime critics of the Emancipation Proclamation and elucidate Spalding's perception of the entire war. In Spalding's opinion, Lincoln's proclamation represented the adverse effects of Protestantism on American society, politics, and culture. The Catholic prelate deemed the Emancipation Proclamation an example of "Puritan hypocrisy [which had] never exhibited itself in a more horrible or detestable" form. ${ }^{4}$ Spalding linked Lincoln's proclamation with other matters of contention between the bishop and his religious adversaries. As the Catholic leader asserted in his journal:

Puritanism, with its preachers \& Common Schools, has at length ruined the Country, as we all foresaw \& predicted it would. May God grant that at length the eyes of America may be opened to its wickedness, \& may see that their only salvation is to be found in Conservative Catholicity: This may be the result of this unhallowed war, thus, in God's Providence, bringing good out of evil. ${ }^{5}$

Spalding not only identified himself as a southern slaveholder but, more

importantly to him, he was a member of the Catholic hierarchy in the United States. The bishop's invective against the Emancipation Proclamation drew from his detestation of Protestantism, particularly New England evangelicalism or what Spalding commonly called Puritanism. In his diocesan journal, Spalding not only attacked Protestantism but he also championed Catholicism, suggesting that adherence to the Church's teachings and principles would have alleviated national problems. Furthermore, the bishop anticipated that more Americans would convert to Catholicism after they realized that Protestantism had driven the nation to civil war, a conflict that Spalding expected to devolve into social insurrection due to the president's executive order.

\footnotetext{
${ }^{4}$ Spalding Journal, CDBL, UNDA, January 1, 1863, p. 44.

${ }^{5}$ Ibid.
} 
Overall, the second half of Spalding's passage illustrates how the bishop interpreted the Civil War through a religious lens informed by his Catholic worldview. Along with other Catholic clergy from the slaveholding Border States, Spalding associated the Republican Party, the Lincoln administration, and the Union war effort with northern Protestantism. During the antebellum period, many northern evangelicals endorsed both the antislavery and anti-Catholic movements; thus, Catholics proved the religious and political antagonists of northern Protestants, who believed that the spread of slavery and Catholicism threatened American values. As Catholic immigration to the United States increased during the decades before the war, Church clergy witnessed a surge in nativist and anti-Catholic sentiments, particularly in the creation of the American or Know Nothing Party. For Bishop Spalding, Archbishops Peter Richard Kenrick of St. Louis and Francis Patrick Kenrick of Baltimore, as well as other Catholic clergy in the United States, defending Church teachings, protecting Catholic institutions, safeguarding the interests of Catholic immigrants, continuing the Church's ministry, and converting Americans to the faith constituted their primary concerns during the era of the Civil War. Furthermore, in addition to defending and promoting Catholicism, many of the clergy developed their own prejudices, most commonly in the form of anti-Protestant rhetoric. Leading Catholic apologists, such as Spalding, defended the teachings and legacy of the Roman Catholic Church while simultaneously attacking Protestant sects, particularly those most hostile to the Church. Thus, by the start of the Civil War, American Catholic clergy had developed a pattern of engaging the political, social, and legal issues of the period by defending and championing Catholicism and arguing that an adherence to Protestantism had created national problems. 
Drawing from an assortment of primary documents, including private

correspondences and diocesan journals, this thesis examines the ways in which Catholic clergy in Missouri, Kentucky, and Maryland interpreted the Civil War. ${ }^{6}$ Underscoring how the conflict between Protestants and Catholics shaped the clergy's perspective of the era, this thesis argues that the clergy interpreted the war foremost through a religious lens and demonstrates how their faith — Catholicism—informed their interpretations of the conflict. Catholic clergy focused on how the war affected the status, permanency, and ministry of the American Church, and also analyzed the war-and its related issuesbased on their own Church doctrine and Catholic worldview. At the same time, the clergy often argued that Catholicism offered alternative recourses for dealing with national issues like slavery that Protestantism could not resolve. Members of the Catholic hierarchy also asserted that the Civil War represented a failure of Protestantism, suggesting that secession and the war could and would have been avoided if the majority

\footnotetext{
${ }^{6}$ Most of the previous works about American Catholics during the Civil War focused on the contents of Catholic newspapers and the clergy's public declarations, such as pastoral letters. Although this thesis incorporates the contents of some of those sources, it relies primarily on the clergy's personal writings, such as letters and diocesan journals. Due to the author's inability to read Latin or Italian at this time, this thesis relies exclusively on the contents of the clergy's correspondences and diocesan journals written in English, unless a translated copy of the documents were included with the original sources. Furthermore, most of the wartime correspondences of Peter Richard Kenrick, archbishop of St. Louis, were destroyed by his successor, Archbishop John Joseph Kain. For more information, see: F. G. Holweck, "Historical Archives of the Archdiocese of St. Louis," St. Louis Catholic Historical Review 1 (October 1918): 24-39. Due to the destruction of many of Peter Richard Kenrick's letters, this thesis concentrates largely on the Catholic sees of Louisville, KY and Baltimore, MD during the war. Lastly, this thesis centers on Bishop Martin John Spalding's tenure in Kentucky, rather than his time as archbishop of Baltimore. Although the Vatican transferred Spalding to the See of Baltimore in 1864, following the death of Francis Patrick Kenrick, this thesis analyzes primarily his writings as bishop of Louisville. Overall, the thesis reflects archival research conducted at the University of Notre Dame Archives in Notre Dame, IN and the Associated Archives at St. Mary's Seminary and University in Baltimore, MD.
} 
of Americans had subscribed to the Catholic faith. Furthermore, this thesis contends that the interconnectedness of the antislavery and anti-Catholic movements led most Church clergy in the region to consider members of the Republican Party and supporters of the Union war effort to be anti-Catholic. As a result, Border State clergy, such as Spalding and the Kenricks, opposed many of the wartime policies of the Lincoln administration because they associated the president and his supporters with anti-Catholicism. In a region where loyalties remained divided throughout the war, Border State Catholic clergy shared a political alliance with northern Democrats and Confederates; however, unlike Democrats who denounced the Republican Party for partisan reasons and Confederates who opposed the party's antislavery policies, Catholic clergy disparaged the party of Lincoln because of its affiliation with anti-Catholicism.

In large part, this thesis mirrors the arguments and methodology employed by James Hitchcock in his article "Race, Religion, and Rebellion: Hilary Tucker and the Civil War." Hitchcock's work analyzed the wartime diary of Father Hilary Tucker, assistant rector of the cathedral in the Diocese of Boston. Born and reared in Perryville, Missouri, Tucker attended seminary at St. Mary of the Barrens near Perryville and studied in Rome at the College of the Propaganda. After graduation, he returned to the United States to serve as a pastor in the Diocese of Chicago before being transferred to Boston. By the start of the Civil War, Tucker served in a diocese comprised of individuals with starkly different social values and customs than his own. ${ }^{7}$ Due to his background as a Catholic from Missouri, "Tucker associated abolitionism with a Protestant fanaticism which was the seed of the Know Nothings and other anti-Catholic

\footnotetext{
${ }^{7}$ James Hitchcock, "Race, Religion, and Rebellion: Hilary Tucker and the Civil War,” The Catholic Historical Review 80 (July 1994): 497-499.
} 
movements." ${ }^{\prime 8}$ This association caused Tucker to interpret the Civil War as a "religious conflict, a terrible moral deformity begotten by a perverted religion." ${ }^{9}$ According to Hitchcock, Tucker believed that "the fanatical spirit of abolitionism" caused the war, and the Catholic priest attributed abolitionism to northern Protestantism, which Tucker argued was a "straight line" derivative of Puritanism and Calvinism. ${ }^{10}$ Thus, in Tucker's opinion, the Union war effort represented the interests of northern Protestants-who denounced both Catholics and slaveholders—causing him to look upon the war and the Republican Party "with untempered loathing."

Tucker's brother, Father Louis Tucker, also served as a parish priest; however, Louis remained in Missouri during the war and maintained correspondence with his sibling. In letters dated during the fall of 1864 , Louis Tucker wrote disdainfully about required loyalty oaths for clergy in Missouri, which the priest attributed to the efforts of Missouri's Radical Republican government. ${ }^{12}$ Following the war, Tucker returned to his native state, where he uncovered evidence of the destruction of Catholic institutions at the hands of the Union Army. Tucker's diary reported "the depredations of the Union troops, who had left the marks of cannon balls on St. Michael's church and rectory"; the northern soldiers also committed sacrilegious acts, such as profaning the Blessed Sacrament. ${ }^{13}$ The wartime letters written by his brother and his own experiences in Missouri in 1866 only helped to solidify Hilary Tucker's belief that the Republican Party and the Union war effort harbored anti-Catholic sentiments. According to Hitchcock, Tucker never

\footnotetext{
${ }^{8}$ Ibid., 499.

9 Ibid., 502.

${ }^{10}$ Ibid.

11 Ibid.

${ }^{12}$ Ibid., 511-513.

${ }^{13}$ Ibid., 510.
} 
abandoned his religious interpretation of the war. His final entries in 1867 continued "to view the conflict as entirely the fault of a depraved Yankee Puritanism." ${ }^{14}$ Ultimately, this thesis supports the arguments made by Hitchcock because it shows how other Catholic clergy interpreted the war through a religious lens. Similar to Tucker, Bishop Spalding, the Kenricks, and other prelates and priests in the Border States associated northern abolitionists, the Lincoln administration, and the Union war effort with antiCatholicism. Furthermore, Border State Catholic officials opposed many of the wartime policies enacted by federal and state governments, such as required loyalty oaths for clergy, because they argued that the requirements infringed on religious and civil liberties and violated the separation of church and state. Finally, clergy in the Border States also charged that the Union Army targeted Catholic institutions and committed sacrilegious acts because supporters of the war sought to undermine the American Church.

In large part, Catholic clergy like Hilary Tucker perceived of the Civil War as a religious conflict due to the "interpretative framework" of prelates and priests. ${ }^{15}$ In addition to the work of Hitchcock, this thesis draws from the scholarship of Judith Conrad Wimmer, who produced a dissertation in 1979 that analyzed how American Catholics interpreted the war. According to Wimmer, the apologist movement ${ }^{16}$ proved the greatest influence on the interpretative framework of Church leaders during the era. "The themes developed in that apologetic," wrote Wimmer, "were put to use to explain

\footnotetext{
${ }^{14}$ Ibid., 517.

${ }^{15}$ Judith Conrad Wimmer, "American Catholic Interpretations of the Civil War," PhD dissertation, Drew University, 1979, 325.

${ }^{16} \mathrm{~A}$ term used to describe the intellectual movement spearheaded by Catholic clergy and lay leaders from the nineteenth century that defended the Church and its teachings against Protestant and secular critics. In addition to defending their faith, Catholic apologists also attacked Protestantism and argued that its principles led to the world's political, social, and economic problems.
} 
the divisions in the nation ... The civil conflict clearly indicated that the nation was threatened by Protestant principles. These principles were not conducive to civil liberty in the context of an ordered society." 17 At the same time, however, clergy argued that "Catholic principles ... alone could assure such liberty" and would prevent any political divisions within the nation. ${ }^{18}$ In addition to the apologist movement, Wimmer analyzed other influences on the interpretative framework of the clergy, showing how theological differences with Protestants, the legacy of the European Church, and the immigrant experience impacted Catholic perceptions of the Civil War. As Wimmer explained:

Interpretations of the war offered by Protestant preachers and theologians involved the application of biblical and theological themes to the nation, really a dialogue with and development of a theology of the nation begun in the earliest days of American history. The primary categories used by the American Catholics were drawn from their European heritage and their experience as an immigrant or minority church in this country; not so much a theology of the nation as a theology of the Church. Since the time of the Reformation, the Church had been developing an apologetic which emphasized the value of Catholic culture and principles for the life of any civilized nation. This apologetic made clear that whatever good was to be found in a society-liberty, culture, etc.- - was due to the influence of Catholicism. ${ }^{19}$

According to Wimmer, Catholic principles "were preeminently conservative: a centralized authority, respect for law and the authority of the Constitution." ${ }^{, 20}$ In fact, most scholars who have written about nineteenth-century American Catholicism have too often dismissed Catholic leaders, their interpretative framework, or their principles as simply being "conservative." For example, David Walker Howe, a highly regarded historian of the antebellum period, wrote that the "Roman Catholic Church in the United States adopted a position not far removed from that of southern evangelical

\footnotetext{
${ }^{17}$ Wimmer, 325.

${ }^{18}$ Ibid.

${ }^{19}$ Ibid., 342.

${ }^{20}$ Ibid., 325.
} 
Protestantism - if anything, more conservative." ${ }^{21}$ In explaining the Church's position toward slavery, Howe noted that Catholic teachings "sanctioned the institution [slavery] so long as masters permitted slaves to marry and receive religious instruction ... Their religion honored the spiritual discipline of patient suffering and submission more than Protestantism did ... Sometimes individuals had to sacrifice for the sake of public order or community welfare, even to the point of accepting enslavement." ${ }^{22}$ Other historians, however, have suggested that describing American Catholicism during the era as just "conservative" proves problematic because it fails to take the Church's teachings and its leaders seriously. As Catholic historian W. Jason Wallace explained:

Catholic opinion about slavery was conservative if "conservative" means opposing the social vision of northern evangelicals. This does not mean that the American Catholic Church lacked a social vision. Rather, it suggests that any attempt to understand the American Catholic social vision in the decades leading up to the Civil War must wrestle with what the contours of a conservative tradition look like. The fact that many twentieth-century historians have chosen to dismiss antebellum Catholicism as conservative, and therefore hostile to democratic reform, is an indication of just how successful northern evangelicals were in encouraging the notion that Catholicism stood outside the boundaries of political liberalism. ${ }^{23}$

This thesis follows the lead of historians like Wallace who strive to evaluate critically the opinions, visions, principles, and interpretations of Catholics during the era. Regarding the topic of this thesis, Wallace's arguments help explain why Catholic prelates like Spalding opposed the policies of Lincoln and the Union war effort. By understanding and appreciating the intellectual framework of nineteenth-century Catholic

${ }^{21}$ David Walker Howe, What Hath God Wrought: The Transformation of America, 1815-1848 (New York: Oxford University Press, 2007), 479.

${ }^{22}$ Ibid.

${ }^{23}$ W. Jason Wallace, Catholics, Slaveholders, and the Dilemma of American Evangelicalism, 1835-1860 (Notre Dame, IN: University of Notre Dame Press, 2010), 145 . 
leaders, it becomes clear that Spalding denounced Lincoln and his policies because he maintained a contrasting social vision or worldview compared to the president's, a difference that the Louisville bishop would have ascribed to religious dissimilarities. Rather than dismissing Spalding as a conservative slaveholder from Kentucky, this thesis considers how his religious beliefs - along with those of his fellow Border State clergyshaped Catholic interpretations of the war. In doing so, this thesis sheds light on an alternative perspective of the war and the various issues related to the conflict. The historiography of the Civil War era has focused on the experiences and religious perspectives of three groups: the white Protestant North, the white Protestant South, and African Americans. Aside from the work on the Irish-American laity who served in the Union Army, few scholars have analyzed American Catholics during the war, especially how Catholic theology and dogma informed the ways in which clergy interpreted the conflict.

Finally, the thesis adds to growing scholarship on the religious history of the Civil War, particularly the recent work on the Border States completed by Luke E. Harlow. In Religion, Race, and the Making of Confederate Kentucky,1830-1880, Harlow argued that the majority of Kentuckians adopted a post-war Confederate identity due to the establishment of proslavery religion in the state during the antebellum period. Focusing on the three largest denominations in the state-Baptists, Methodists, and Presbyterians-Harlow showed how the state's connection with the southern branches of evangelical Protestantism influenced Kentucky's course of action before, during, and after the war. According to Harlow, evangelicals believed that northern abolitionists proved the greatest threat to the nation because they remained "hell-bent on tearing down 
the most basic foundations of Christian America: its faith, its unity, and its racial stratification, all of which the slavery system secured." ${ }^{24}$ With a population that constituted seventy-percent of the state, white evangelical Protestants supported a policy of neutrality during the early months of 1861 because they shared a commitment to the slave system and principles of white supremacy with their coreligionists in the seceded states. Ultimately, the state legislature voted to abandon neutrality and keep Kentucky in the Union; nevertheless, following 1862, federal policies-including the issuance of the Emancipation Proclamation and the enlistment of African Americans in the Union Army_-initiated a loyalty shift in Kentucky. As a result, by as early as 1863 , white evangelicals from Kentucky began to unite with their coreligionists from the Confederacy to preserve the antebellum racial order. ${ }^{25}$ Thus, the effects of the Emancipation Proclamation and the enlistment of African American troops in the state convinced the majority of evangelicals in Kentucky to adopt Confederate religion during the post-war period, thereby aligning socially and politically the once loyal state with those that had seceded. As Harlow showed throughout his work, religion played a fundamental role in preserving slavery in antebellum Kentucky, maintaining unionism during the sectional crisis and first two years of the war, initiating the state's loyalty shift after 1862, and aligning Kentucky with the Lost Cause during the postwar period. In the end, Harlow determined that "Conservative [evangelical Protestant] religion made Confederate Kentucky."26

${ }^{24}$ Luke E. Harlow, Religion, Race, and the Making of Confederate Kentucky, 1830-1880 (New York: Cambridge University Press, 2014), 109.

${ }^{25}$ Ibid., 158-184.

${ }^{26}$ Ibid., 223. 
Harlow's work proves significant to this thesis because it illustrates how religion played a central role in determining the opinions, sympathies, and interpretations of Border State residents during the war. Similar to Harlow's claim that an adherence to southern evangelical Protestantism shaped how the majority of Kentuckians viewed the war, this thesis contends that the religious beliefs and principles of Catholic clergy in the Border South influenced how they interpreted the conflict. Within the last decade, the Border States have received significant attention from Civil War scholars. Much of this work has focused on the politically divided populaces within each state, shedding light on the various factors that determined individual allegiances. In addition to the various political, economic, or social determinants, this thesis joins Harlow's work in arguing that religion played a fundamental role in shaping the opinions and sympathies of Missourians, Kentuckians, and Marylanders during the Civil War era.

Divided into five chapters, this thesis begins with a historiographical review of scholarship about American Catholicism and Civil War-era religion. The chapter discusses the state of scholarship on the Roman Catholic Church in the United States during the nineteenth century, examining the various arguments that have been made about the Church and indicating how this thesis adds to the study of Catholicism and religion overall during the Civil War. Furthermore, by examining a range of scholarship about American Catholicism during the period, the first chapter outlines the various factors that shaped the interpretative framework of clergy at the time of the war. The chapter argues that to understand how Border State prelates and priests interpreted the Civil War one must appreciate the changes that occurred within the American and European churches during the period as well as consider how the religious contention 
between Catholics and Protestants impacted the clergy's perceptions of the conflict. Lastly, the chapter analyzes how recent scholars have upended the perception of the American Church as a monolith during the war, showing how Catholic opinion varied across the United States by region and ethnic background.

The second chapter establishes the social, political, and religious contexts within the Border States before the war. In particular, the chapter focuses on the state of Catholicism within each of the three episcopal sees that this thesis surveys: Baltimore, Louisville, and St. Louis. The chapter provides a concise history of the Archdioceses of Baltimore and St. Louis and the Diocese of Louisville, explaining how the Church grew in each bishopric before the war. The chapter also examines the backgrounds of the archbishop or bishop of each Border State see—Bishop Martin John Spalding of Louisville and Archbishops Francis Patrick Kenrick of Baltimore and Peter Richard Kenrick of St. Louis — in order to illustrate how their experiences as Catholic leaders during the antebellum period influenced their interpretations of the war. In particular, the prelates' encounters with anti-Catholicism or nativism—such as the Louisville election riot of 1855-helped fuel the Catholic apologist movement and foment anti-Protestant feelings among the clergy. Overall, the chapter demonstrates that by the start of the war the religious leaders in each of the three Border States associated the Republican Party with anti-Catholicism, believed that northern abolitionists were responsible for the sectional crisis, and argued that Catholicism offered a resolution to national issues.

The third chapter explores the period from the election of 1860 through the first months of the war. In doing so, the chapter analyzes how the Border State clergy responded to the election of Lincoln, the secession crisis, and the commencement of 
fighting in their dioceses. Although most clergy in the region hoped for the election of northern Democratic candidate Stephen Douglas in 1860, none of the prelates or priests supported secession in reaction to Lincoln's victory. In fact, the clergy argued that Catholic officials should remove themselves from national politics, suggesting that the invasion of Protestantism into the political process - in both the North and the Southhad created the national crisis. Border State clergy hoped for the preservation of the Union and supported policies of neutrality to avoid having their respective dioceses drawn into the war. However, once the fighting began, the clergy promoted peace and sought to continue the ministry of their Church despite the calamities of civil war, though some anticipated that the clergy would ultimately have to choose sides in the contest.

The fourth chapter examines the American Church's relationship with slavery, particularly the way in which Border State Catholic leaders defended the institution as a "legitimate human relation that could be maintained justly." ${ }^{27}$ The chapter explores the private correspondences and published works — theological and theoretical—authored by Border State clergy on the issue. Overall, the clergy endorsed a gradual emancipation plan, arguing that the Catholic Church offered a viable alternative for dealing with the institution, one which would have prevented secession and civil war. Overall, the fourth chapter offers scholars an alternative perception of the dilemma over American slavery during the era. Compared to the division within mainstream Protestantism—which pitted those who believed that the Bible condemned slavery against those who believed that scripture condoned human bondage — Catholic clergy offered a unique perspective that has not received as much attention from historians. Finally, the fifth chapter analyzes the

\footnotetext{
${ }^{27}$ Wallace, 119.
} 
concerns that Border State clergy had with civil liberties issues during the war. Prelates and priests from the region considered required loyalty oaths for clergy, the confiscation and destruction of Church property, and forced conscription of clergy in their dioceses to be actions that violated the separation of church and state, a concept the clerics valued for the protection of their religion in a Protestant-dominated society. Most importantly, many of the clergy argued that the violations of the separation of church and state derived from a perceived anti-Catholic sentiment associated with members of the Union war effort.

Overall, this thesis argues that the religious affiliation of Border State residentsparticularly Roman Catholic clergy in Missouri, Kentucky, and Maryland—influenced their interpretations of the war. Furthermore, the thesis demonstrates that the contention between Protestants and Catholics during the antebellum period influenced wartime sympathies. Due to the interconnectedness of the antislavery and anti-Catholic movements as well as the Republican Party's connection with former nativist groups, such as the Know-Nothings, Catholic leaders from the Border South considered the Republican Party and the Union war effort to be anti-Catholic. Finally, this thesis provides an alternative perspective of the Civil War era, one that has not received much attention from scholars. Few historians have analyzed how Catholic clergy interpreted the war or considered how one's faith—especially Catholicism—shaped individual understandings of slavery, secession, civil war, or civil liberties disputes. 


\section{CHAPTER I}

\section{A HISTORIOGRAPHICAL REVIEW OF AMERICAN CATHOLICISM DURING THE CIVIL WAR ERA}

In Battle Cry of Freedom: The Civil War Era, James McPherson's 1988 seminal work on the era of the American Civil War, the author dedicated twenty-five pages of his 862-page tome to the study of American Catholicism. In particular, McPherson focused on the impact of German and Irish immigration to the United States during the final three decades before the war. As McPherson explained, by 1854, Protestant fears of a heightened Catholic presence and influence in the nation led to the rise of nativist and anti-Catholic sentiments and the emergence of new political parties, specifically the Know-Nothings. Furthermore, McPherson described how anti-Catholicism linked several of the social reform movements— such as temperance and abolitionismchampioned by northern evangelicals during the antebellum period. McPherson limited his coverage of Catholicism during the war years to a few pages about the role of Archbishop John Hughes of New York, the enlistment of Irish Catholics in the Union Army, their role in the New York City draft riots, and the prevalence of Copperhead sentiment among northern and Border State Catholics. ${ }^{28}$ Despite the limited analysis of Catholicism in Battle Cry of Freedom, McPherson did not overlook or dismiss an extensive historiography of the topic. In fact, his synthesis reflected accurately the state

28 James M. McPherson, Battle Cry of Freedom: The Civil War Era (New York: Oxford University Press, 1988), 7, 30-33, 131-137, 142, 156, 223, 493-494, 507, 606611. 
of Civil War-era scholarship during the late-1980s, when few historians expressed an interest in the study of religion during the war. However, since the publication of Battle Cry of Freedom, Civil War historians and American religious historians have underscored the relationship between organized religion, individual faith, and providential thinking, and the social, political, and military histories of the war. Works by Mark Noll, Robert J. Miller, George C. Rable, David Goldfield, and Timothy Wesley, among others, have covered an array of topics related to the intersection of American religion and Civil War-era politics. As these works have shown, northerners and southerners discussed the war from pulpits, in prayer meetings, and through the religious press; likewise, references to scripture, testaments of faith, and individual understandings of divine providence appeared within political documents, soldiers' letters, and homefront ruminations. ${ }^{29}$

Nonetheless, much of the recent historiography on the religious history of the Civil War has concentrated on American Protestants. Most authors have limited their

${ }^{29}$ This thesis discusses the arguments and analyses of most of the following works within the body of the historiographical review. For more information on the religious history of the Civil War, see: C. C. Goen, Broken Churches, Broken Nation: Denominational Schisms and the Coming of the American Civil War (Macon, GA: Mercer University Press, 1985); Gardiner Shattuck, Jr., A Shield and a Hiding Place: The Religious Life of the Civil War Armies (Macon, GA: Mercer University Press, 1987); Randall M. Miller and Harry S. Stout, eds., Religion and the American Civil War (New York: Oxford University Press, 1998); Steven E. Woodworth, While God is Marching On: The Religious World of Civil War Soldiers (Lawrence: University of Kansas Press, 2001); Mark A. Noll, The Civil War as a Theological Crisis (Chapel Hill: The University of North Carolina Press, 2006); Robert J. Miller, Both Prayed to the Same God: Religion and Faith in the American Civil War (Lanham, MD: Lexington Books, 2007); George C. Rable, God's Almost Chosen Peoples: A Religious History of the American Civil War (Chapel Hill: The University of North Carolina Press, 2010); David Goldfield, America Aflame: How the Civil War Created a Nation (New York: Bloomsburg Press, 2011); Timothy L. Wesley, The Politics of Faith during the Civil War (Baton Rouge: Louisiana State University Press, 2013). 
analyses of American Catholicism during the war to a single chapter or a few pages within each chapter of their monographs. Although members of the Church represented a minority group in a Protestant-dominated society, Catholics comprised approximately ten percent of the overall population and represented one of the largest denominations in the nation in 1860 . Thus, Catholics constituted a sizeable—and rapidly growing—segment of the American populace at the start of the war. The marginal treatment of American Catholicism in histories of the Civil War has likely resulted not from a perceived lack of importance of the Church during the period but rather from the lack of cohesion between American Catholic historians and Civil War historians. In fact, much of the history of American Catholicism has been written by members—often clergy—of the Church, and few scholars outside the field of American Catholic history, particularly Civil War historians, have demonstrated much interest in the experiences of American Catholics, save the Irish who fought for the Union Army. Although his words were written to reflect the entire scope of United States historiography, John Ellis's assertion that the "familiar interpretation of [American] history" has been "narrowly Protestant" proves particularly true for the study of the Civil War. ${ }^{30}$

Despite the dearth of attention given to American Catholicism in studies that cover the years 1860 to 1865 , Early Republic and antebellum historiographies include several works that examine the growth of the Church in the United States, as well as analyze how Protestants reacted to the expansion of American Catholicism. In fact, the history of Catholicism in the United States during the Civil War era incorporates and integrates a broad variety of subjects and fields related to nineteenth-century

${ }^{30}$ John Tracy Ellis, American Catholicism, second edition (Chicago: The University of Chicago Press, 1969), $\mathrm{x}$. 
historiography. In addition to the study of a particular religious group, historians of nineteenth-century Catholicism have contributed to scholarship on immigration, American ethnic studies, identity formation and citizenship, antebellum politics and policymaking, and issues related to religious tolerance and the separation of church and state. Much of the historiography, however, has treated the subject of Catholicism through the lens of American Protestantism, failing to consider the various American Catholic interpretations of events during the periods before, during, and after the war.

To understand how American Catholics interpreted the Civil War, one must consider the developments in both the American Catholic Church and Roman Catholicism overall during the nineteenth century, as well as maintain an appreciation for the context of the American Catholic Church in a Protestant-dominated society that witnessed sectional strife over slavery, secession, and civil war. As John T. McGreevy elucidated, the American Catholic perspective during the Civil War era was defined by an "interplay" between Catholic and mainstream Protestant ideas about the future of the nation. ${ }^{31}$ As a result, historians must "capture two traditions in motion, not one: to explore American ideas about Catholicism along with the predispositions (at times blinders) framing the mental landscape of American Catholics" due to their experiences in a culturally Protestant environment. ${ }^{32}$ Furthermore, historians interested in American Catholicism during the Civil War era must be mindful that a single Catholic interpretation of the war did not exist; rather than a monolithic Catholic voice, several opinions, viewpoints, and interpretations emerged among Church members. Therefore,

${ }^{31}$ John T. McGreevy, Catholicism and American Freedom (New York: W.W. Norton \& Company, 2003), 14.

32 Ibid., 14-15. 
the study of American Catholicism during the Civil War era involves a combination of the historiography of the Church — both in the United States and abroad—and the historiography of religion during the antebellum and Civil War periods. At the same time, scholars must underscore how Catholic opinion varied during the era based one's place of residence, ethnicity, and social class.

\section{General Catholic Histories}

John Tracy Ellis published one of the first modern histories of American Catholicism, which placed the history of the American Church within the context of United States history from the colonial period to the mid-twentieth century. Ellis described how Church members constituted a minority of the overall population in antebellum American. Nonetheless, its population grew during the 1840s and 1850s due to Irish and German immigration. The rise in the immigrant Church population led to conflict between Protestants and Church leaders over several issues, particularly the use of the King James Bible in public schools. Controversies erupted in northern cities, such as Philadelphia and New York, over Catholic students being forced to use the King James Bible and recite Protestant prayers in school. Many Catholic leaders responded by requesting public funds to construct Catholic schools where Catholic students could be educated by Church members and receive a sound Catholic education. As Ellis noted, controversies over education coincided with other movements, such as temperance, to produce a rise in nativist and anti-Catholic prejudices in the North. By the time the Civil War began, Catholics had encountered increased resistance from northern Protestants, who organized the Know Nothing Party on an anti-immigrant platform. ${ }^{33}$ Ellis dedicated

\footnotetext{
${ }^{33}$ Ellis, 63-86.
} 
twenty-two pages to the period from 1852 to the 1870 s, in which he argued foremost that the "spiritual and organizational union [of American Catholicism] was never in jeopardy" compared to American Protestantism. ${ }^{34}$ Although Catholics fought on both sides during the war and Church officials supported opposing governments, Ellis contended that the war never produced the same level of crisis as it did within Protestant America. The Church never condemned slavery; therefore, controversies over what the Bible said about slavery did not divide American Catholics. In fact, Ellis stated that the southern clergy strove to improve the condition of African Americans by offering educational opportunities for some blacks. Nonetheless, the "combination of anti-abolitionism and anti-Catholicism" in the South prevented the Catholic Church from providing anything more than the most basic educational and religious instruction for African Americans. ${ }^{35}$ If the Church attempted anything more, American Catholics risked attack and persecution from southern Protestants for threatening the social order of the antebellum South. Regarding the politics of the war, Ellis sought to cast the American Church as maintaining a neutral position, refusing to endorse either the Union or the Confederacy. Instead, clergy encouraged nonintervention, peace, and a quick end to the war, while allowing the laity to form their own opinions and choose their own course of action during the conflict. And even those clerics, such as Archbishop John Hughes of New York and Bishop Patrick Lynch of Charleston, who supported their respective governments did so in a "dignified dispute," which "contrasted favorably with the

\footnotetext{
34 Ibid., 93.

35 Ibid., 92.
} 
conduct of certain Protestant ministers like Henry Ward Beecher and others who ... dishonor[ed] the pulpit by their fanatical outbursts about the war."36

Prior to the 1960s, most Catholic historians offered narratives of the war similar to Ellis's analysis of the American Church from 1860 to 1865 , in which scholars emphasized the "neutral" position of the Church and the American clergy's "apolitical" stance during the war. Most American Church historians produced diocesan histories or biographical studies of major Catholic clerics that did not engage with the contemporary historiographical movements or trends in the study of the Civil War era. The diocesan or biographical works on American Catholicism treated the war only in terms of how the conflict affected local communities, parishes, dioceses, or Catholic leaders. Furthermore, these works contended that the war erupted due to divisions within Protestant America and argued that the American Church should remain blameless for inciting secession or civil war. Similar to Ellis's history of American Catholicism, most works prior to the 1960s argued that American Catholics were silent, aloof, or neutral during the sectional crisis and the war, choosing only to speak out to promote peace. ${ }^{37}$

Judith Conrad Wimmer, however, authored the first important study of the American Church during the Civil War that challenged directly many of the arguments made by previous scholars. Instead of positing that only a minority of the American hierarchy espoused a political position during the war, Wimmer demonstrated that in fact "very few American Catholics maintained a neutral position in both their public and

\footnotetext{
36 Ibid., 98.
}

37 Judith Conrad Wimmer, "American Catholic Interpretations of the Civil War," PhD dissertation, Drew University, 1979, 16-89. 
private lives. ${ }^{38}$ Although the politics of slavery did not sunder the Church during the antebellum period, secession produced divisions among both American clergy and laity, despite the official declarations of neutrality issued by the Church. Wimmer's study, which involved an examination of Catholics in both sections, explored numerous homilies, circulars, lectures, and pastoral letters produced by leading clergy during the war to demonstrate that "American Catholic spokesmen in the North and the South took political positions." 39 As Wimmer explained, the clergy "articulated" their positions "with intelligence and sophistication," and responded to the war in both political and theological ways. ${ }^{40}$ Furthermore, clerics in both the Union and the Confederacy "raised flags over their churches, blessed their flags and occasionally even their cannon." ${ }^{41}$

Despite the political divisiveness within the American Church, Catholic leaders across the nation shared in their providential interpretations of the war. Between 1861 and 1865 , clergy spoke about the hand of providence "working through the tragedy of human bloodshed, to bring new life to the nation." ${ }^{\text {42 }}$ Unlike many Protestant clergy who often portrayed the war as punishment for the national sin of slavery, Catholic leaders viewed the war as "chastisement of sins, but these were sins often unrelated to the war itself[:] . . pride, boastfulness, materialism and forgetfulness of God. ${ }^{, 43}$ Thus, Catholic leaders - except for a select few in the North—often spoke about the war creating a new nation, but their visions did not compare to those of northern Protestants who often spoke
38 Ibid., 15.
39 Ibid., 10.
${ }^{40}$ Ibid.
${ }^{41}$ Ibid.
${ }^{42}$ Ibid.
${ }^{43}$ Ibid., 278. 
about a new nation without slavery. ${ }^{44}$ Overall, the Civil War offered Catholics the opportunity to compare their principles with Protestantism. According to Wimmer, Catholic clerics may have supported opposing armies and governments during the war but they united in a defense of Catholic principles by charging that Protestantism had incited the conflict. In addition to perceiving the war as purification for "evil and corruption," Catholic clergy also believed that the war would prove to the American populace that they needed to adopt Catholic principles. ${ }^{45}$

Published in 1981, James Hennesey's American Catholics: A History of the Roman Catholic Community in the United States offered a similar narrative of the American Church during the war. In keeping with Wimmer's conclusions, Hennesey argued that secession forced Catholics to align with their regional governments. Northern Catholics became patriotic for the Union by denouncing the attack on Fort Sumter, and southern Catholics fell in line with the Confederacy by defending slavery and the right to secede. For example, Hennesey juxtaposed the responses of Archbishop John Hughes of New York who flew the American flag above his cathedral and supported conscription with Bishop John Quinlan of Mobile who stated: "“While regretting the dismemberment of the great Republic ... we [southern Catholics] would not purchase Union at the expense of Justice." "46 Hennesey also described the response of Catholics in the Border States as "mixed," due to the presence of a large immigrant population who often enlisted in the Union Army combined with a native-born slaveholding population who supported a policy of neutrality while denouncing

${ }^{44}$ Ibid., 234-279.

45 Ibid., 276, 280-330.

${ }^{46}$ James Hennesey, American Catholics: A History of the Roman Catholic Community in the United States (New York: Oxford University Press, 1981), 151. 
abolitionism. ${ }^{47}$ Even the majority of Catholics in the North opposed the immediate emancipation of slaves, in part because leaders in the American Church had articulated a theological defense of slavery during the antebellum period. In his moral theology textbook, which remained "standard fare in American seminaries," Archbishop Francis Patrick Kenrick “'regret[ted]' that there were so many slaves, whose liberty and education were so restricted," yet he also "emphasi[zed] ... that the law must be obeyed to avoid chaos." ${ }^{\text {"48 }}$ Rather than challenging American laws that permitted slavery in the South, Kenrick insisted that lay Catholics remain moral masters and urged fellow Catholic clergy to ensure that slaves received the sacraments of baptism, communion, confirmation, and marriage. ${ }^{49}$

Choosing to employ a bottom-up approach to American Church history, recent works by Jay P. Dolan and James M. O'Toole examined the experiences of the Catholic laity in the United States. Regarding the antebellum and Civil War years, Dolan and O'Toole underscored the urbanization of the Church that began during the 1840s. For example, the diocesan see in Kentucky moved from Bardstown — which had served as the center of Catholicism in the state since 1808 - to Louisville in 1841 in order to serve the growing immigrant Catholic population in the city. ${ }^{50}$ The advent of nativism and antiCatholicism paralleled the urbanization and growth of the American Church. Although most of the convent burnings and anti-Catholic riots occurred in the North, towns in the

${ }^{47}$ Ibid., 152-155.

48 Ibid., 146.

${ }^{49}$ Ibid., 144-147.

${ }^{50}$ Jay P. Dolan, The American Catholic Experience: A History from Colonial Times to the Present (New York: Doubleday \& Company, 1985), 161; James M. O'Toole, The Faithful: A History of Catholics in America (Cambridge, MA: Belknap Press, 2008), 95-119. 
South, Midwest, and California also witnessed their own violent outbursts. ${ }^{51}$ The contentious relationship between Protestants and Catholics, according to Dolan, represented a clash of cultures during the antebellum period, when the Protestant majority expressed concern about the success of the American democratic experiment. Thus, the growing Catholic population-which most Protestants believed subscribed to an antidemocratic religion - "threatened the homogeneity of the Anglo-Saxon Protestant culture of the United States." ${ }^{52}$ While defending themselves against the rise of anti-Catholicism, American Catholics underwent their own religious revival during the 1840s and 1850s, as many Church members demonstrated a turn toward devotional Catholicism. ${ }^{53}$ As Dolan explained, "Coloring the Catholic view of sin was an attitude toward the world or secular society that was quite negative." $" 54$ Anti-Catholic riots and poor conditions in many American cities served as evidence to Catholics that the world had become a wicked, sinful place. Devotional Catholicism attributed the wickedness of the secular to Protestantism, thereby instilling in most antebellum American Catholics a "strong antiProtestant tone."55 "In trying to understand why devotional Catholicism was so popular," wrote Dolan, "certain social and psychological reasons should be noted . . Catholics experienced a good deal of ethnic and religious discrimination. Yet, religious discrimination worked both ways, with the anti-Protestant tone of devotional Catholicism

${ }^{51}$ Dolan, The American Catholic Experience, 201-202; O’Toole, 87-90.

${ }^{52}$ Dolan, The American Catholic Experience, 201.

${ }^{53}$ Dolan, The American Catholic Experience, 228-238; O’Toole, 124-129.

${ }^{54}$ Dolan, The American Catholic Experience, 228.

${ }^{55}$ Ibid. 
only serving to widen the chasm that divided Catholics and Protestants" in the decades before the Civil War. ${ }^{56}$

In Catholicism and American Freedom, John T. McGreevy placed the Catholic revival and other developments within the universal Church during the nineteenth century within an American context, showing how events in Europe influenced American Catholic perceptions of politics and society in the United States. As McGreevy explained, "Catholic intellectuals in the United States influenced by the revival defined themselves against dominant ideas of freedom ... Opposition to liberal notions of autonomy informed Catholic hostility to immediate slave emancipation, nonsectarian education, and laissez-faire economics."57 At the same time, within the broader transAtlantic world, anti-Catholicism became synonymous with liberty, as European revolutionaries sought to overthrow the political powers of Pope Pius IX and American Protestants strove to suppress Catholic influence in their nation. Because American Protestants considered Catholicism the antithesis of liberal democracy, they crafted national histories that excluded Catholic contributions during the colonial and Early Republic periods. Rather than accepting the anti-Catholic-laden Protestant interpretations, Catholic clergy and lay leaders commenced an apologist movement during the mid-nineteenth century. Led by Bishop Martin John Spalding of Louisville, Catholic apologists crafted their own counter narratives that placed Catholic contributions at the forefront. For example, Spalding "claimed trial by jury, habeas corpus, and fair taxation for Catholics." 58
56 Ibid., 238.
${ }^{57}$ McGreevy, 13.
${ }^{58}$ Ibid., 19-37. 
The ecclesiastical division that developed between ultramontanes and Gallicanists (or Catholic liberals) in the European Church also influenced the worldview of antebellum American Catholics. Largely affiliated with Jesuit principles, ultramontanes placed emphasis on the authority of the pope. Conversely, Gallicanists challenged the pope's temporal powers, some even going so far as to express anti-papal sympathies. Although McGreevy argued that the "division between liberal and ultramontane Catholics was never as clear in the United States as in France and Germany," American Catholic prelates expressed opposing opinions regarding the pope's authority, particularly concerning the dogma of papal infallibility. ${ }^{59}$ However, American Catholics shared an understanding of what constituted freedom, and, as McGreevy explained, the Catholic definition differed from Protestant understandings. Rather than adhering to the views of non-Catholic liberals, like John Stuart Mill, who "understood freedom as an autonomous self, exempt from external constraint," Catholics "saw moral choice and personal development as inseparable from virtues nurtured in families and churches." ${ }^{, 60}$ Catholics believed that free individuals required a moral authority—-the Church—- to inform and guide them to make proper choices. Whereas Protestants placed an emphasis on individual autonomy, Catholics held steadfast to the notion that freedom for freedom's sake — the liberty to act without a higher authority directing appropriate behavior—would result in disorder and instability. "Erroneous understandings of freedom," Catholics argued, "threatened the foundations of society." divergent understandings of freedom influenced Catholic and Protestant interpretations of

\footnotetext{
${ }^{59}$ Ibid., 29-30, 84, 103.

${ }^{60}$ Ibid., 36.

${ }^{61}$ Ibid., 37.
} 
the major issues affecting mid-nineteenth-century America: the state of public education, the separation of church and state, and the expansion of slavery. ${ }^{62}$

\section{Historiography of Nineteenth-Century American Anti-Catholicism}

According to distinguished historian Martin Marty, the roots of American antiCatholicism can be traced to the Reformation period in Europe. As he explained in Pilgrims in Their Own Land: 500 Years of Religion in America, the battle between European Catholics and Protestants, which began in the sixteenth century, spilled over into the New World. Marty argued that the "exploring and settlement of North America" during the seventeenth and eighteen centuries reflected "the battles over faith that divided Europe."63 As French and Spanish Catholics acquired land in the northern and southern sections of North America respectively, English and Dutch Protestants settled in the New England and the Chesapeake regions. Catholics arrived in Maryland and enjoyed early success in the colony; however, the ascension of William and Mary to the English throne in 1689 led to the suppression of Catholics. By 1701, Marylanders had established the Church of England in the colony and created new laws that restricted the civil liberties of Catholics. ${ }^{64}$ Although Catholic privileges waned under the new regime, the Church maintained its presence in the colony and oversaw Catholic missions into the West following American independence. From Maryland, Catholics moved into Kentucky and other territories to establish churches, seminaries, and convents. Parallel to the Catholic missionary expansion, Protestant sects—particularly the newly formed evangelical denominations - witnessed increased growth during the period of the Second Great

${ }^{62}$ Ibid., 36-90.

${ }^{63}$ Martin Marty, Pilgrims in Their Own Land: 500 Years of Religion in America (New York: Little Brown, 1984), 42.

${ }^{64}$ Ibid., 53-89. 
Awakening. As Americans claimed lands and settled in the West during the earlynineteenth century, the competition between Catholicism and Protestantism intensified, as both groups sought to supplant the other in the region and increase their church populations. As Marty demonstrated, religious conflicts that developed in sixteenthcentury Europe shaped the contention between Catholics and Protestants in the United States. The confrontation only deepened during the three decades before the Civil War as scores of Irish and German immigrants arrived on American shores. ${ }^{65}$

In 1938, Ray Allen Billington authored the first significant work that analyzed the Protestant response to European-Catholic immigration to the United States during the antebellum period. Titled The Protestant Crusade, 1800-1860: A Study of the Origins of American Nativism, Billington's work argued that xenophobia and anti-Catholicism proved successful social movements that garnered abundant support among American Protestants during the first half of the nineteenth century. However, the movement failed as an organized political party, which experienced only a few years of success during the mid-1850s, particularly at the local and state levels. Although a period of religious toleration existed in the United States following the Revolution, heightened levels of immigration, according to Billington, led to the rise of anti-Catholic sentiment. Protestants considered Irish and German immigrants, as well as French Jesuit missionaries, the shock troops of the pope, who sought to entrench Pius IX's influence in American society and politics. ${ }^{66}$ Billington attributed events such as the burning of the Ursuline convent in Charlestown, Massachusetts in 1834 to the "sensationalism"

${ }^{65}$ Ibid., 169-188.

${ }^{66}$ Ray Allen Billington, The Protestant Crusade, 1800-1860: A Study of the Origins of American Nativism (New York: Macmillan Company, 1938), 1-47. 
promulgated by leading evangelicals, such as Lyman Beecher. ${ }^{67}$ Protestant preachers and publishers extended anti-Catholic polemics from the pulpit and in the mainstream press throughout the 1830s and 1840s, which produced a widespread anti-Catholic and antiimmigrant grassroots movement in the United States. ${ }^{68}$

By the mid-1840s, several towns and communities—-particularly in the North and Old Midwest — had organized their own local nativist societies. According to Billington, the spread of evangelical Protestantism helped to link the various local groups around a national movement, regardless of denomination or sect, which sought to suppress immigrant and Catholic influence in the nation. ${ }^{69}$ Although the movement was started by upper and middle-class Protestants, by the 1850s working-class citizens had joined the cause, leading to an increase in urban riots and anti-Catholic demonstrations. As Billington explained, Americans from all social classes came to believe that "the influx of aliens threatened their established social structure, endangered the nation's economic welfare, and spelled doom for the existing government system." ${ }^{, 70}$ Thus, political nativism offered "protection from the social, political, and economic evils which seemed inevitably linked with the immigrant invasion.."71 As a result, beginning in 1854, members of the Know Nothing Party ascended to political power in states located in the North and Border South. Although the Know-Nothings "professed vehement enmity for immigrants," Billington argued that at the core of their movement remained a "hatred of
67 Ibid., 67.
68 Ibid., 85-160.
${ }^{69}$ Ibid., 168-209.
${ }^{70}$ Ibid., 322.
71 Ibid. 
Catholicism." ${ }^{72}$ The 1854 Kansas-Nebraska Act and the controversy over the expansion of slavery, which led to the demise of the Whig Party, opened the door for the emergence of the Know-Nothings. However, as Billington explained, the slavery issue also proved the "death knell" for the Know-Nothings, who failed to sustain a national party focused solely on a nativist or anti-Catholic platform. ${ }^{73}$

More recent works, including Tyler Anbinder's Nativism and Slavery: The Northern Know Nothings and the Politics of the 1850s, have offered improved analyses of the rise and fall of the party. Similar to Billington, Anbinder showed how the Know Nothing Party failed as both an antislavery and anti-Catholic party, due to the contention between northern and southern members over the party's official stance about slavery. Developed as a party for evangelicals in the urban North, the Know-Nothings garnered members who opposed a wide variety of issues. In addition to resisting immigration and the expansion of Catholicism, the Know Nothing Party gained support from those who opposed the sale and consumption of alcohol, the creation of parochial schools, and the passage of the Kansas-Nebraska Act of 1854. Anbinder also demonstrated that the Know Nothing Party offered antislavery advocates a political home, in large part because many Protestants believed that the Catholic Church supported the extension of slavery. Antiimmigrant sentiment intensified during the 1840s and 1850s, according to Anbinder, because the type of Irish and German immigrant differed from the one who had traveled to the United States in previous decades. The potato blight of 1845 led to economic and social decline in Ireland, forcing droves of poor, unskilled, and Catholic immigrants to flee the country for the United States. The impoverished and overtly Catholic refugees

\footnotetext{
72 Ibid., 386.

73 Ibid., 430.
} 
who arrived in American ports after 1845 proved the primary concern for Protestant nativists who worried about the immigrants' impact on the society and economy of the United States. $^{74}$

Anbinder demonstrated that the Know-Nothings underwent two waves as a political party. After emerging on the political scene in the summer of 1854 and until 1856, the Know-Nothings focused on an anti-immigrant and anti-Catholic platform. Anbinder identified the following as the "six basic tenets" of the first wave of the party: the United States was a Protestant nation; Catholicism was not compatible with American values; Catholics manipulated the American political process by bloc voting; immigrants contributed to fraudulent voting; the American party system and professional politicians were corrupt; and the United States should adopt laws that limited the extension of slavery and alcohol consumption. ${ }^{75}$ With this platform, the Know-Nothings won elections in several northern and midwestern states, such as Massachusetts, New York, Pennsylvania, Ohio, and Indiana. However, factionalism, specifically differences among members regarding the expansion of slavery, prevented the Know-Nothings from becoming a successful nationalized party. During 1856 and 1857—-the party's final two years-members adopted a pro-Union platform that avoided the slavery question. ${ }^{76}$ By this point, the American Party (the term used by Anbinder to refer to the second wave of Know-Nothings) recognized that most of the "radical anti-slavery and temperance advocates" had left for the Republican Party; therefore, members endorsed a platform that "would attract an entirely new constituency, one that placed perpetuation of the

74 Tyler Anbinder, Nativism and Slavery: The Northern Know Nothings and the Politics of the 1850s (New York: Oxford University Press, 1992), 3-51.

${ }^{75}$ Ibid., 104-106.

${ }^{76}$ Ibid., 127-193. 
Union above all other issues. ${ }^{, 77}$ Following the 1856 presidential election, support for the Know Nothing or American Party was limited to the Border States. In time, the party's focus on unionism gave rise to the Constitutional Union Party of $1860 .^{78}$ Although the "slavery issue contributed to the Know Nothings' speedy demise," sentiments of the party's original platform—nativism and anti-Catholicism—did not expire but were adopted by members of the Republican Party, many of whom had been former KnowNothings. ${ }^{79}$

The pervasiveness of anti-Catholicism in antebellum America constituted the focus of immigration historian Jon Gjerde's Catholicism and the Shaping of NineteenthCentury America. In his final manuscript, completed and edited by S. Deborah Kang, Gjerde explained the story of "America's encounter with Catholicism" as a "conversation"—often bitterly disputed—between Protestants and Catholics. ${ }^{80}$ In doing so, Gjerde showed how the contestation between Protestants and Catholics proved central to the formation of American society and government. Religious conflict, according to Gjerde, helped "buil[d] a nation" because it forced Americans to grapple with issues of religious tolerance, ethnic pluralism, the appropriate relationship between church and state, changing gender roles during the antebellum period, and the state of the American economy and education system. ${ }^{81}$

During the nineteenth century, Protestants and Catholics faced "conundrum[s]," or what Gjerde referred to as the political and social challenges that each religious group

${ }^{77}$ Ibid., 195.

${ }^{78}$ Ibid., 246-278.

${ }^{79}$ Ibid., xiii.

${ }^{80}$ Jon Gjerde, Catholicism and the Shaping of Nineteenth-Century America, edited by S. Deborah Kang (New York: Cambridge University Press, 2012), i.

${ }^{81}$ Ibid., viii. 
faced as they sought to remain homogenous in a rapidly growing pluralistic nation. ${ }^{82}$ As Catholics and Protestants formed their own unique visions for antebellum America, both groups had to "balance their commitments to religious freedom with their convictions that their religion was vital to the state and nation. ${ }^{.83}$ The Protestant conundrum involved the toleration of a perceived oppressive and repressive religion they viewed as incompatible with American values, such as republicanism and an individual's right of conscience. Protestants believed they had founded a Protestant nation that would prove successful only if the United States remained a foil to Catholic Europe. Due to concerns about the influence of Catholicism in the young republic, the Founding Fathers, according to Gjerde, espoused the separation of church and state because "the Roman Catholic Church was the exemplar of the dangers of the established church." ${ }^{84}$ Nevertheless, the majority of Protestants believed that "the separation of church and state did not mean ... that there should be a separation of the nation from Protestant Christianity." ${ }^{85}$ Furthermore, as the level of Catholic immigration to the United States increased during the nineteenth century, Protestants began to question the extent of religious freedom. In order to protect religious freedom (for Protestant Christians), most Americans argued that Catholicism proved the exception to religious tolerance in the United States because a growing Catholic populace threatened Protestant America. As Gjerde explained, the Protestant conundrum was clear: "if toleration were extended too

${ }^{82}$ Ibid., 26, 67, 91.

${ }^{83}$ Ibid., $\mathrm{x}$.

${ }^{84}$ Ibid., 47.

${ }^{85}$ Ibid., 57. 
far, it might ultimately lead to its own demise and authoritarianism and despotism would return. .86

Catholics responded by underscoring the hypocrisy of Protestants, who delivered anti-Catholic harangues while championing religious freedom and tolerance. Ultimately, Catholics refused to accept the Protestant argument that "[i]ntolerance [proved necessary] for the sake of tolerance. ${ }^{, 87}$ Not only did they reject Protestant charges about the Church's incompatibility with American values, Catholic officials and publishers also attacked Protestantism. For example, Bishop Martin John Spalding argued that the growth of Protestantism had transformed the United States into a " "paradise of infidels"” by giving rise to far too many -isms: “'Universalism, Unitarianism, Fourierism, Parkerism, [and] Transcendentalism." ${ }^{88}$ Spalding and other Catholic apologists claimed that the level of religious freedom in the United States had led to social and political disorder because the growth of Protestantism had eroded a shared orthodoxy and consensus among the nation's populace. Even though Catholics constructed effective defenses of their religion and underscored the problems associated with Protestantism, Church members faced their own unique dilemma. According to Gjerde, the Catholic conundrum constituted the following: "how [could] the Church be pluralistic and liberal, on the one hand, and particularistic on the other [?] ${ }^{\prime 89}$ For the Catholic Church to survive and grow in the United States, Church officials recognized that the institution would have to adapt to American society; nonetheless, clergy proved unwilling to abandon Church traditions, customs, and doctrine in order to assimilate into Protestant-dominated
${ }^{86}$ Ibid.
${ }^{87}$ Ibid., 58.
88 Ibid., 79.
${ }^{89}$ Ibid., 91. 
America. As Gjerde explained, the Catholic conundrum only intensified as Irish and German immigration increased and anti-Catholic politics strengthened during the decades before the Civil War. ${ }^{90}$

According to Gjerde, the exchanges that occurred between Protestants and Catholics centered on three primary issues of debate: the school, the family, and the economy. According to Protestants, schools inculcated American values and produced an educated youth that would ensure the success of liberal democracy in the United States. Contemplating whether or not they should accommodate Catholic teachings in public schools, Protestants asked the following: "If conscience, tolerance, and freedom were Protestant virtues, how could the nation be sustained if youth were neither instructed in them nor permitted to utilize them?"91 Most Protestants answered by arguing that only the King James Bible would be allowed in schools and that all students would be required to recite the Protestant Ten Commandments. Catholics called foul, reminding Protestants about religious tolerance and the separation of church and state (in this case state-funded schools). ${ }^{92}$

Protestants and Catholics also possessed alternative perceptions of the nineteenthcentury family: Protestants viewed the family as a private haven that protected their faith from the vice-ridden world, and Catholics treated the family as a small unit within their larger religious organization. According to Gjerde, Protestants and Catholics critiqued their adversary's perception of the family as a way of attacking their religion. For example, Protestants authored invectives about the "prisonlike convent, the celibate
${ }^{90}$ Ibid., 61-95.
91 Ibid., 172.
92 Ibid., 138-175. 
priest, and the secretive confessional" to charge that the Church oppressed women, undermined procreation, and authorized inappropriate intermediaries to intervene as heads of households. ${ }^{93}$ Likewise, Catholics argued that Protestantism had given birth to increased "individualism, materialism, and fanaticism" which eroded "parental power" and poisoned the "American home." ${ }^{94}$ According to Gjerde, Protestant efforts to undermine Catholic education and the Church's perception of the family led to Catholic "pillorization" during the nineteenth century, which included the development of a Catholic parochial school system and religious orphanages. ${ }^{95}$ Using Catholic Mexico as a contemporary nineteenth-century example, Protestants charged that the Catholic Church had a history of impeding the economic progress of nations. Furthermore, Protestants, especially northern proponents of free labor, argued that the Church's position toward slavery meant that Catholics conspired with the Slave Power to spread the institution into the West. On the other hand, Catholics criticized American free-market capitalism for giving birth to "wage slavery," which, they argued, impoverished a number of Catholic immigrant laborers in the urban North. ${ }^{96}$ Rather than allowing the American economy to promulgate increasing levels of materialism and greed, Catholics proposed a "corporate ideal that mitigated against individual excesses in the polity and economy." ${ }^{97}$ And, as Gjerde explained, Catholic appeals to corporatism "complemented the arguments of proslavery ideologues who set the master-slave relationship in a context of other societal

\footnotetext{
93 Ibid., 184.

${ }^{94}$ Ibid., 218.

95 Ibid.

96 Ibid., 223.

97 Ibid., 244.
} 
arrangements of reciprocal inequality."98 As a result, the economic viewpoints of Catholics and proslavery apologists aligned in opposition to those of the reform-minded northern Protestants, who Catholics and southerners deemed too self-righteous and fanatical.

In addition to Gjerde, W. Jason Wallace has also underscored the political "[a]lignment" that developed between American Catholics - in both the North and the South—and southern proslavery apologists. ${ }^{99}$ Although Catholics and Protestant slaveholders disagreed about theological questions, the two groups possessed a common political and social adversary: northern evangelicals. Throughout the first half of the nineteenth century, northern evangelical ministers, activists, and publishers charged that both Catholics and slaveholders endangered "American values."100 These arguments reached a wide audience during the period because they often appeared within the religious press. Invectives against Catholicism and slavery were often printed on the same pages or within the same volumes of several Protestant periodicals because both were considered forms of captivity — either physical or mental — that related to life in preReformation Europe. Evangelicals attributed the problems of Europe to the power of the Catholic Church, which they viewed as an oppressive religious, social, and political regime. According to northern evangelicals, Old World forms of oppression had reemerged in the United States in the form of slavery in the South. ${ }^{101}$ Evangelical publishers typically "compared the immoral authoritarianism of the Catholic priest to the

98 Ibid., 251.

${ }^{99}$ W. Jason Wallace, Catholics, Slaveholders, and the Dilemma of American Evangelicalism, 1835-1860 (Notre Dame, IN: University of Notre Dame Press, 2010), 2. 100 Ibid., 1.

101 Ibid., 71-88. 
immoral authoritarianism of the slaveholder. Both were portrayed by the press as brutal, lecherous, and most importantly, un-American."102

According to Wallace, the period from 1835 to 1860 constituted a "historical moment" for northern evangelicals, the majority of whom believed that God had ordained them to direct the proper course of American society and government. ${ }^{103}$ Considering Catholicism and slavery both repressive and oppressive, northern evangelicals enacted "crusades" against the two in hopes of eliminating both from the United States. ${ }^{104}$ In doing so, northern evangelicals applied theology to politics, believing that "religion [specifically evangelical Protestantism] was indispensable to the progress of the young country" and that Protestantism provided an appropriate "moral conscience" for the nation. ${ }^{105}$ As a result, a "powerful sectional ideology" developed in the North, specifically among New Englanders, that identified Catholics and slaveholders as individuals who threatened the future of Christian America. For northern Protestants, however, their specific religious and regional ideology created two particular dilemmas within American evangelicalism. The first involved Catholicism and its place (if any) within the nation. While as Americans they championed religious freedom and tolerance, most northern Protestants considered Catholicism incompatible with American political and social values. As a result, many evangelicals argued that Catholicism proved the exception to religious tolerance in the United States because its existence directly threated American democracy. Slavery constituted the second dilemma because it prevented a unified American evangelical vision for the United States. Northern and
102 Ibid., 4.
103 Ibid., 18.
104 Ibid., 13.
105 Ibid., 17, 2. 
southern evangelicals "did not share the same vision of liberty and equality," causing many of the mainstream evangelical denominations - such as the Baptists and Methodists - to divide into proslavery and antislavery factions during the antebellum period. ${ }^{106}$ As Wallace explained, “[d]espite efforts to define the young country as a Christian nation united in its commitment to Protestant ideals, northern evangelicals could not reconcile the place of Catholics or slaveholders in their narrative." 107

Wallace also analyzed American Catholic responses to the anti-Catholic and antislavery movements. As Wallace explained, historians have been too quick to dismiss the Church as "too conservative"” when analyzing Catholic opinions about slavery and religious tolerance during the period. ${ }^{108}$ Rather than describing the Church in simple or vague terms, Wallace took the Catholic position toward slavery and the Church's defense of its own doctrine and historical record seriously. Regarding the dispute over slavery, Catholic officials sought foremost to keep the Church out of the national controversy. In fact, the majority of American Catholics denounced both abolitionists and secessionists as Protestant fanatics that threatened the Union. Although the Vatican never offered an official pro- or antislavery position, the Church maintained a theological tradition on slavery that viewed the institution as "a legitimate human relation that could be maintained justly." ${ }^{109}$ For example, Bishop John England of Charleston, South Carolina cited the teachings of Thomas Aquinas to argue that slavery was "praeter naturam, a justifiable addition to nature ... grounded in human reason and designed to serve the
${ }^{106}$ Ibid., 3.
107 Ibid.
${ }^{108}$ Ibid., 144.
109 Ibid., 119. 
general welfare of all." ${ }^{\prime 10}$ And Bishop Francis Patrick Kenrick of Philadelphia, Pennsylvania stated that slavery evolved from "the disorder generated by sin," thus "[b]ecause sin altered the original state of freedom in which people were created, perfect freedom could never again be attained through either political or social manipulation." Although England and Kenrick offered defenses of slavery, both Catholic clergy argued that the Church should provide slaveholders with the proper framework for how to serve as moral, Catholic masters. ${ }^{112}$ Overall, Wallace underscored the interconnectedness of the anti-Catholic and antislavery movements during the antebellum period, and showed that religious — and not just regional or sectional—contention proved central to the political and social debates that occurred in the United States before the Civil War.

As Wallace and other antebellum-era historians have noted, the period of Manifest Destiny represented American Protestant beliefs about a perceived ordination from God to spread their religious, social, and political institutions across North America. In Missionaries of Republicanism: A Religious History of the Mexican-American War, John C. Pinheiro showed how Protestant Americans justified the conflict as means of not only spreading Protestantism but, more importantly, eliminating Catholicism from the continent. As Pinheiro explained, "Anti-Catholic rhetoric constituted an integral piece of nearly every major argument for or against the war and was so universally accepted among whites that recruiters, politicians, diplomats, journalists, soldiers, evangelical activists, abolitionists, and pacifists used it."113 Pinheiro also demonstrated that the era of

${ }^{110}$ Ibid., 123.

111 Ibid., 125.

112 Ibid., 119-126.

113 John C. Pinheiro, Missionaries of Republicans: A Religious History of the Mexican-American War (New York: Oxford University, 2014), 1-2. 
the Mexican-American War constituted a period of identity formation in the United States. By the early decades of the nineteenth-century, most Americans believed that the United States represented "all of those things that Mexico was not: free, Protestant, republican, and prosperous." ${ }^{114}$ Using Mexico as a foil, most white Americans embraced Anglo-Saxonism as the central feature of their national identity because, as Pinheiro explained, they believed that Anglo-Saxonism had given birth to "Protestantism and republicanism—religion and government for free men." ${ }^{\prime 15}$ Nonetheless, AngloSaxonism did not equate to "whiteness" during the nineteenth century because most Protestant Americans believed that white Catholics lacked the ability to both conceive of and participate in free government. As Pinheiro explained, racial distinctiveness at the time of the Mexican-American War "was not starkly between white and black. Rather, it was more of a complex web that prevented white unanimity about race solely because of religion." "116 However, according to Pinheiro, the Mexican-American War made it "even easier" for white Protestants to formulate a national identity that excluded Catholics, because "Mexicans were not only Catholic but non-white in color and non-English in ancestry."117

Protestants invested in the extension of slavery welcomed the war as an opportunity to expand the institution and to eliminate Catholicism in North America. Although they expressed more nativist — and similarly anti-Catholic — sentiment than Democrats, Whigs did not support the annexation of Texas, deeming it "either too
${ }^{114}$ Ibid., 3.
115 Ibid., 2.
${ }^{116}$ Ibid., 9.
117 Ibid., 10. 
Mexican [Catholic] or too black."118 Whigs also opposed "“Mr. Polk's War"” because many party members viewed it as part of a plan devised by southerners to extend slavery. ${ }^{119}$ Members of the Native American Party, the forerunner of the KnowNothings, both opposed the war and criticized the Polk administration for allegedly favoring Catholics. Although the Native Americans condemned the Whigs and Democrats for being too lenient on immigration, they supported the annexation of Texas - thereby allowing millions of foreign Catholic immigrants into the United States - in order to spread Protestantism in the West. As Pinheiro explained, Native Americans interpreted the war foremost as an attack against Catholicism, and used the religious themes of the conflict to attack political enemies. ${ }^{120}$

For northern evangelicals, the majority of whom were Whigs, the MexicanAmerican War proved a theological and political conundrum because it thrust upon them the following dilemma: "Which, then, was the greater threat to the Gospel and purity of the American republic: slavery or Catholicism?"121 Although northern evangelicals welcomed a war that would eliminate Catholicism, they opposed the expansion of slavery in the United States. According to Pinheiro, by 1848 the majority of northern evangelicals had adopted a "moderate stance between ardently pro-war and anti-war views," choosing instead to concentrate on the potential missionary work that could be accomplished in the West. ${ }^{122}$ Due to heightened anti-Catholic sentiment during the war,

\footnotetext{
118 Ibid., 43.

${ }^{119}$ Ibid., 8.

${ }^{120}$ Ibid., 36-66.

${ }^{121}$ Ibid., 8.

122 Ibid., 12.
} 
most northern evangelicals viewed its conclusion in a more positive light because it

opened the door for the spread of Protestantism in the nation. ${ }^{123}$

\section{Cultural and Literary Anti-Catholicism before the Civil War}

According to many cultural and literary scholars, the anti-Catholic sentiment that pervaded nineteenth-century society was popularized, developed, and dispensed by American authors, journalists, and publishers. Jenny Franchot's Roads to Rome: The Antebellum Protestant Encounter with Catholicism offered the first substantial analysis of American anti-Catholic literature during the decades before the Civil War. Examining an assortment of works produced in the United States during the first half of the nineteenthcentury, Franchot argued that "anti-Catholicism operated as an imaginative category of discourse through which antebellum American writers of popular and elite fictional and historical texts indirectly voiced the tensions and limitations of mainstream Protestant culture." ${ }^{24}$ The height of anti-Catholicism erupted at a time when Americans grappled with uncertainty about the success of their democratic experiment. As Franchot explained, Protestants believed that liberal democracy would only succeed in the United States if the country remained free of Catholic or papal influences. Pre-Reformation Europe represented the pinnacle of the Church's power, and Protestant authors indicated that concerns about the United States devolving into a nation with an established Catholic Church proved the greatest influence on their writings. As Franchot explained, Protestants authored tales about lewd priests, sexualized nuns, conspiratorial Jesuits, and

${ }^{123}$ Ibid., 128-152.

${ }^{124}$ Jenny Franchot, Roads to Rome: The Antebellum Protestant Encounter with Catholicism (Berkeley: University of California Press, 1994), xvii. 
the atrocities of the Inquisition as a means of defining what Protestant-American culture and society was not. ${ }^{125}$

Furthermore, America's earliest historians, such as Francis Parkman and William Prescott, crafted anti-Catholic narratives of the nation's founding. Arguing that the United States developed as a beacon of Protestantism, Parkman and Prescott portrayed the Catholic Church as the colonists' primary adversary which had driven them from Europe. Thus, anti-Catholicism formed the original national identity for AngloAmericans because it unified all colonists during the earliest stages of American history. Interestingly, Parkman and Prescott attributed any aspect of success or progress in the development of the United State to Protestantism. For example, Prescott's Conquest of Mexico (1844) portrayed Hernán Cortés as a Protestant and the Aztecs (Mexica) as a people who practiced Catholicism. In Prescott's account of the fall of the Aztec Empire, Cortés defeated the natives and claimed their land in order to spread Protestantism in North America. ${ }^{126}$ Overall, Franchot showed how antebellum writers utilized antiCatholicism as a way of identifying the United States as a Protestant nation that served as a foil to Catholic Europe. Similarly, anti-Catholic writers championed Protestantism while simultaneously portraying Catholics as the primary obstacle of progress.

According to Susan M. Griffin, fiction proved "the appropriate form for religious controversy" in nineteenth-century America and Great Britain. ${ }^{127}$ Antebellum Americans and Britons read popular works such as Maria Monk's Awful Disclosures of the Hotel Dieu Nunnery (1836) and Charles Frothingham's Six Hours in a Convent: or The Stolen

${ }^{125}$ Ibid., xx-xxiii, 16-34, 113-175.

126 Ibid., 36-82.

${ }^{127}$ Susan M. Griffin, Anti-Catholicism and Nineteenth-Century Fiction (New York: Cambridge University Press, 2004), 2. 
Nuns! (1854), which told tales about the kidnapping, imprisonment, torture, and rape of Protestant women and children at the hands of Catholic officials. Furthermore, many of these works described a Vatican-led conspiracy designed to overthrow the government of the United States and replace it with a despotic regime led by the pope. Although Griffin noted that "not ... every or even most Protestant readers believed that sensational nativist fictions represented Roman Catholicism with scrupulous fidelity," she demonstrated that the tales reflected Protestant concerns about the "cultural, political, and legal issues of the day." "128 Not only did the popular anti-Catholic fictions serve to challenge Catholic theology, but they also constituted a means for Protestant self-identification. As Griffin explained, when anti-Catholics published their works they were "defining, defending, and criticizing - Protestant America and Britain." "129 Thus, the popularity of anti-Catholic fiction not only served to attack the Church, but the pervasiveness of these tales also represented "an integral and shaping part of cultural controversy" in antebellum America. ${ }^{130}$

According to Elizabeth Fenton, much of the cultural contention developed from concerns about the breakdown of a homogenous Protestant society due to Catholic immigration and the growth of the American Church. Fearing Catholic absolutism, Protestants and other non-Catholics believed that an increased presence of the Church during the developmental stages of the United States threatened the realization of liberal democracy. Protestants considered their religious denominations far more accommodating and conducive to pluralism than Catholicism; therefore, non-Catholic

\footnotetext{
${ }^{128}$ Ibid., 13, 3.

129 Ibid., 17.

130 Ibid., 26.
} 
leaders sought to counter Catholic absolutism in order to preserve a Protestant society. As a result, they championed "religious pluralism and its corresponding 'right of conscience'- two highly prized features of liberal democracy," which Fenton argued “drew their force from anti-Catholicism." ${ }^{131}$ Fenton's work Religious Liberties: AntiCatholicism and Liberal Democracy in Nineteenth-Century U.S. Literature and Culture demonstrated the integral role of anti-Catholic sentiment in the formation of American society and government. Fenton explained why "antebellum Anglo-Protestants could simultaneously tout their commitment to egalitarianism and mount campaigns to disenfranchise their Catholic neighbors." ${ }^{.132}$ During the Early Republic period, nonCatholic leaders established the concepts of religious tolerance and the separation of church and state in order to ensure that the Catholic hierarchy would not have undue influence in the formation of America. According to Fenton, America's Founding generation considered the development of these concepts possible because the overwhelming majority of political leaders had not joined the Catholic Church. Thus, they believed that religious tolerance developed in the United States because the United States was not a Catholic nation. ${ }^{133}$

By the early decades of the nineteenth-century, the settlement of the West drew the attention of Protestant leaders. Evangelicals warned about the possibility of losing the West to the Catholic Church, thereby preventing the growth of Protestantism and solidifying the future of the United States as a Catholic nation. As Fenton explained,

${ }^{131}$ Elizabeth Fenton, Religious Liberties: Anti-Catholicism and Liberal Democracy in Nineteenth-Century U.S. Literature and Culture (New York: Oxford University Press, 2011), 4.

132 Ibid., 9.

133 Ibid., 18-35. 
Lyman Beecher's A Plea for the West (1835), which stated that "the religious and political destiny of our nation is to be decided" in the region west of the Mississippi River, grew in popularity and galvanized much of the evangelical population around a perceived threat of Catholicism. ${ }^{134}$ A Presbyterian minister from New England, Beecher argued that the future success of the United States required that Americans prevent the spread of Roman Catholicism, because Beecher considered the religion "the most skillful, powerful, dreadful system of corruption to those who wield it and of debasement and slavery to those who live under it, which ever spread darkness and desolation over the earth." ${ }^{135}$ Fenton linked Beecher's work to the rise of nativism in the United States because Beecher referred to a European threat rather than the growth of the American Catholic Church. Beecher's greatest fear was not the American or "Protestantized" Catholic who had been born and reared in a nation of liberal democracy but the foreign Catholic who had been exposed to the absolutism or "popery" of the European Church. ${ }^{136}$ Fenton also described how many of the anti-Catholic fictional works analyzed by Franchot and Griffin blended with Beecher's writings to cultivate the intense antiimmigrant and anti-Catholic environment that defined much of the late-1830s, 1840s, and 1850s in the United States. As Fenton argued:

[Beecher's] Plea brings to light the ways in which nativist writing of the $1830 \mathrm{~s}$ drew on an already extant body of U.S. fiction to give force to its anti-Catholic arguments. Beecher's Plea and writings like it did not suddenly spring up in response to immigration. Rather, nativist discourse grew out of a narrative tradition ... which presented Catholicism as the test case for emerging and expanding U.S. liberal democracy. ${ }^{137}$ $1835), 11$.

${ }^{134}$ Lyman Beecher, A Plea for the West (Cincinnati, OH: Truman and Smith,

135 Ibid., 142.

${ }^{136}$ Fenton, 52-56.

137 Ibid., 53. 
Many nineteenth-century historians have argued that Harriet Beecher Stowe authored the single most important book in antebellum America. Most historians consider Uncle Tom's Cabin foremost an assault against slavery and the social order of the Old South. However, Tracy Fessenden argued that "the novel routinely credited with abolishing slavery relied for at least part of its force on anxieties surrounding religious conversion."138 Similar to Franchot and Griffin, Fessenden argued that Protestants employed anti-Catholic themes as a way of defining the other in antebellum America. However, in Uncle Tom 's Cabin, Stowe, a white evangelical born in Connecticut, portrayed "others" as not only Catholics but also African Americans and southerners. Fessenden stated that "religious otherness [had] become a secular vocabulary [for] racial otherness," because "Occasionally in Uncle Tom's Cabin ... the same habits of description will accommodate slaveholders as easily as slaves, as though Catholic, Southern, and African modes of the exotic and erotically charged were equally useful for setting against a white New England Protestantism marked by industry, thrift, and emotional reserve."139 Thus, Fessenden proclaimed that evangelical abolitionists-like Stowe-sought not only to free the slaves but to Protestantize and assimilate them into New England culture. By alluding to a connection between Catholicism and southern society, Uncle Tom's Cabin underscored the perceived interconnectedness of emancipation (freedom) and evangelization among Protestants in nineteenth-century America. $^{140}$

138 Tracy Fessenden, Culture and Redemption: Religion, the Secular, and American Literature (Princeton, NJ: Princeton University Press, 2007), 111.

${ }^{139}$ Ibid., 113-114.

140 Ibid. 


\section{$\underline{\text { Southern Catholicism during the Nineteenth Century }}$}

Despite the pervasiveness of anti-Catholicism among northern evangelicals, like Stowe, recent studies of the Old South have depicted a more congenial relationship between Catholics and Protestants. In fact, the American Church grew out of the South, having its roots in colonial Maryland as well as a longstanding presence in French Louisiana. Prior to the influx of European Catholic immigrants in the North, the American Church was concentrated in the Upper South states of Maryland and Kentucky, as well as along the Gulf Coast. From these regions, Catholic settlers and missionaries expanded into areas of the West and throughout the Deep South to establish churches, seminaries, convents, schools, and, eventually, new dioceses. ${ }^{141}$ Published as a collection of essays in 1983, Catholics in the Old South provided the first book-length study of the Church in the southern states, where evangelical Protestantism dominated religion, society, and culture. According to Randall Miller, the southern Church proceeded cautiously-in comparison to the militant-Catholicism employed by Irish Catholics in the North—as to not incite conflict with their Protestant brethren. Furthermore, Miller contended that Catholicism integrated well with evangelical Protestantism in the Old South because "[i]nsomuch as Southern culture respected the family, ascriptive authority, and the ethic of honor, the Catholic Church did not enter a wholly alien society."142 However, the Church's relationship with slavery proved most important in marking the assimilation of Catholicism in the region. As Miller explained, Catholics proclaimed "the

${ }^{141}$ Randall Miller and Jon Wakelyn, eds., Catholics in the Old South, second edition (Macon, GA: Mercer University Press, 1999), 53-76.

${ }^{142}$ Ibid., 7. 
rightness of slavery, the litmus test of Southerness," in large part because "the Catholic Church was a slaveholding church, inextricably bound up in managing slave property."143

James M. Woods echoed many of the arguments made by Miller and the other contributors to Catholics in the Old South in his more recent synthesis of the Catholic Church in the region. In A History of the Catholic Church in the American South, 15131900, Woods located the history of the Church within the context of southern society by showing not only how Protestants responded to the growth of Catholicism but also how southern Catholics grappled with the prominent issues the plagued many nineteenthcentury Americans: immigration, reform movements, and the political disputes over slavery, to name a few. Woods also noted how the center of American Catholicism started to shift around the mid-1840s from its original location in Maryland to New York. This transition continued throughout much of the middle decades of the nineteenthcentury as European immigrants came to account for the bulk of the Catholic population in the United States. Although most of the Irish and German Catholics settled in the areas of the urban North, manufacturing cities in the Upper South, such as St. Louis, Louisville, and Baltimore, as well as port cities in the Deep South, such as Savannah, also experienced an increase in Catholic immigration. As a result, the Know Nothing or American Party not only gained popularity in the North but also experienced a brief period of success in the South. ${ }^{144}$ According to Woods, the "Know-Nothing uproar deeply affected southern Catholics and their status in the region," causing many of the

143 Ibid., 8.

144 James M. Woods, A History of the Catholic Church in the American South (Gainesville: University Press of Florida, 2011), xi-xv, 250-275. 
native and foreign-born Church members to join the Democratic Party during the antebellum period. $^{145}$

Regarding the Church hierarchy, Woods argued that the majority avoided direct political confrontation with southern Know-Nothing politicians, choosing instead to defend their faith through religious publications — rather than the political stump — and to focus on the growth of their churches or dioceses. ${ }^{146}$ Much like the Know Nothing Party in the North, as explained in Anbinder's work, the controversy over slavery limited the success of the party in the South. By the 1860 presidential election, most KnowNothings in the Deep South had fallen in line behind southern Democratic candidate John C. Breckinridge, who ran a proslavery campaign, and most Know-Nothings in the Upper or Border South chose to support John Bell, presidential hopeful for the Constitutional Union Party. Because Catholics had found a political home with the Democratic Party, many in the Deep South supported Breckinridge, while those in the Border States - most of whom were immigrant voters - cast their ballots for Stephen Douglas and the northern Democratic ticket. ${ }^{147}$ Although slavery divided the Democratic Party and the nation as a whole, Woods argued that the institution "did not destroy the unity of the American Catholic Church" because "Catholics did not see slavery as something intrinsically evil." ${ }^{\prime 48}$ Although slavery did not divide the American Church, secession and war led Catholics from the North and the South to support their respective wartime governments. In the South, the Church's position toward slavery meant that several clergy rallied alongside Confederate politicians who attacked abolitionists as northern fanatics and
145 Ibid., 274.
146 Ibid., 274-285.
147 Ibid., 285-288.
${ }^{148}$ Ibid., 288. 
blamed them for driving the nation to war. Furthermore, many southern clergy openly supported secession and justified Confederate independence. More important than their public support for secession, all the southern clergy, save Archbishop Kenrick of Baltimore, chose not to openly denounce disunion, even if that meant remaining silent or choosing only to speak about a peaceful resolution to the crisis. And even Kenrick, who supported the Union, continued to oppose abolition. ${ }^{149}$ The Church's position toward slavery is best articulated by Confederate Vice President Alexander Stephens who reminded his Protestant brethren that "the Catholic Church had 'never warred against us or our peculiar institutions." "150 As Stephens explained, Catholics posed no threat to southern society because their faith and Church doctrine allowed for the continuation of slavery.

In addition to a shared consensus about slavery, Catholics and Protestants in the Old South also collaborated in areas of education, health care, and institutional growth. Claiming that "tolerance and cooperation, more than violence and animosity, marked Catholic-Protestant relations in the antebellum South," Andrew H. M. Stern showed how the two religious groups lived, healed, educated, worshipped, and ruled together. ${ }^{151}$ Stern argued that because the South obtained fewer Catholic immigrants during the antebellum period than the North southern Protestants did not feel as threated by the Church in their region. Although episodes of violence between Catholics and nativists erupted in the South before the Civil War, Stern contended that far fewer incidents occurred in the

${ }^{149}$ Ibid., 286-295.

${ }^{150}$ Miller, eds., Catholics in the Old South, 17.

${ }^{151}$ Andrew H. M. Stern, Southern Cross, Southern Crucifix: Catholic-Protestant Relations in the Old South (Tuscaloosa: The University of Alabama Press, 2012), 2. 
region than in New England. ${ }^{152}$ Instead of leading violent demonstrations against Catholics, southern Protestants welcomed the Church because it helped fill a void in southern health care and education. As Stern explained, Catholics constructed hospitals and orphanages throughout the South, which would have been unavailable to southern residents without the efforts of Church officials and women religious. Although they provided services to both Catholics and Protestants, the Catholics who operated the hospitals and orphanages did not proselytize to their Protestant neighbors. ${ }^{153}$ As a result, Catholic schools throughout the South, particularly in Kentucky, welcomed prominent members of the Protestant population, including Jefferson Davis. ${ }^{154}$ According to Stern, the contributions of Catholic health care workers and educators created a positive perception of Catholicism and helped to integrate the Church within southern society, even encouraging some Protestant leaders to financially support the development of new Catholic institutions. ${ }^{155}$

\section{Catholicism in the Early American West}

Although Catholics and Protestants may have enjoyed an amiable relationship in areas of the Deep South, Luke J. Ritter's recent dissertation about the pervasiveness of anti-Catholicism in the antebellum West (Kentucky, Missouri, Ohio, and Illinois) portrayed a more contested relationship between the two religious groups. By focusing on a subregion of the Old South—the Border West—Ritter's work challenged the principal arguments about the cooperative and congenial bond between Catholics and Protestants in the region. Ritter showed that instead of a monolith Catholic-Protestant
152 Ibid., 19-36.
153 Ibid., 43-66.
154 Ibid., 70-107.
155 Ibid., 109-131. 
relationship in the South the level of cooperation differed based on the social and political contexts of the various subregions of the South. According to Ritter, nativism and antiCatholicism were inextricably linked in the areas of the antebellum Border West (Kentucky and Missouri), where levels of Catholic immigration were the highest in the South during the decades before the Civil War. The highly concentrated immigrant populations in Border South cities, such as Louisville and St. Louis, threatened the political and social power of the Protestant majority, who sought to maintain the status quo in the region. Protestants believed that immigrants brought "papal" or "popish" qualities of European absolutism to the United States, which threatened to undermine democracy and individual autonomy in the nation. Thus, from an antebellum Protestant perspective, nativism and anti-Catholicism became synonymous with American nationalism because most Protestants in the Border West believed that barring immigrants and Catholics from becoming citizens would ensure the preservation of democracy and freedom. ${ }^{156}$ The "nativist use of anti-Catholicism for political agendas," argued Ritter, "reflected a shift in the relationship between politics and religion: from an inclusive 'religious civility,' in which various Protestant denominational groups prided themselves on their pluralism and independence from government, to an exclusive 'civil religion' where Protestant Americans came to regard Catholics—and European immigrants who seemed to share 'Catholic' customs—as unfit for citizenship.",157

${ }^{156}$ Luke J. Ritter, “Anti-Catholic America: Nativism and Religious Freedom in the Antebellum West," PhD dissertation, Saint Louis University, 2014, 1-34. The citations included in this historiographical essay were drawn from a manuscript version of the dissertation.

157 Ibid., 16. 
Although Ritter focused on the significance of immigration in the growth of the American Church, John R. Dichtl explored the role of Catholic missionaries, Church officials, and women religious in expanding Catholicism into the West following the American Revolution. The decades immediately following independence until the $1820 \mathrm{~s}$ represented a period of religious tolerance in the United States, largely because Catholics posed no social or political threat as a small minority of the population. Although small in numbers, the Church looked to grow by establishing new churches and welcoming new converts into the fold. According to Dichtl, Catholic officials felt encouraged by the period of religious acceptance during the Early Republic and looked to establish a presence in the West. ${ }^{158}$ As the Church expanded into the trans-Appalachian region, priests played a particularly important role, serving as community leaders, protectors of the faith, and financial administrators for the Church. ${ }^{159}$ Nonetheless, some priests brought scandal to the Church, tainting the image of Catholicism for their Protestant neighbors. Issues with corrupt priests as well as problems with trusteeism led to a centralization of power within the American Church. As the American Church appeared more like the European Church, rather than the democratized Protestant denominations, Catholics in the West came under increased scrutiny from not only their Protestant neighbors but also the laity who challenged the power of the American hierarchy. Despite these setbacks, the American episcopate abandoned its attempt at an

${ }^{158}$ John R. Dichtl, Frontiers of Faith: Bringing Catholicism to the West in the Early Republic (Lexington: The University Press of Kentucky, 2008), 1-18.

${ }^{159}$ Ibid., 19-48. 
"Americanized" Catholicism and embraced a centralized structure in order to reestablish order and secure stability for the Church's development in the United States. ${ }^{160}$

Dichtl described the growth of the Church during the Early Republic as occurring parallel to the expansion of evangelical Protestantism in the region. Although Catholics experienced early tolerance from their Protestant neighbors, the centralization and success of the American Church in establishing churches, schools, convents, and seminaries led to some concern, suspicion, and a sense of competition among Protestants by the 1830s. Protestants who encountered the Church often claimed that they were both amazed and disturbed by Catholic customs, rituals, and orthodoxy. For example, John Brown, a Presbyterian law student, noted that he "“was struck with astonishment and horror"” yet "'still greater was [his] surprise"” when he attended his first Catholic mass in Louisville. ${ }^{161}$ Recalling his experience when he entered the church, Brown wrote that “"the first thing that struck my eyes was an awful representation of the mangled body of Christ on the Cross." "162 Essentially, the immediate period of tolerance opened the door for the Catholic Church to establish itself in the West, which zealous Church officials, missionary priests, and women religious took advantage of to construct Catholic institutions throughout the trans-Appalachian region. As Dichtl noted, "[d]uring the first forty years of the Catholic Church's movement westward, cautious optimism gave way to a more assured sense of progress and freedom to be distinctively Catholic." ${ }^{\prime 63}$ The Church's growth and success, however, raised the concerns of many American Protestants in the region who began to question the place of Catholicism in the United
${ }^{160}$ Ibid., 49-85.
161 Ibid., 88.
162 Ibid.
${ }^{163}$ Ibid., 174. 
States. Nonetheless, the Church had successfully established itself in the areas of Kentucky, Missouri, and the greater Ohio Valley so that by the 1830s "western Catholics [were prepared] to respond to the surge of anti-Catholic animosity welling up" in the region. ${ }^{164}$

Unlike Ritter and Dichtl, Margaret C. DePalma downplayed the religious contestation between Catholics and Protestants in the antebellum West, arguing instead that "on the whole the relationship was amiable and cooperative."165 DePalma grounded her thesis in an examination of four early American clergy-Archbishop John Carroll of Baltimore, Father Stephen T. Badin of Kentucky, Bishop Edward Dominic Fenwick of Cincinnati, and Archbishop John Baptist Purcell of Cincinnati-all of whom DePalma described as Catholic officials who "walked a fine line between American republicanism and traditional European Catholicism." According to DePalma, the personalities of the four clergy made it possible for Catholics and Protestants to cooperate and develop their respective religious groups alongside one another in the West from 1793 to 1883.

Interestingly, DePalma used much of her book to describe how Protestant concerns about the influence of Catholicism in the nation increased following 1830; nonetheless, she contended that instances when Protestants offered financial support to the Churchinstead of nativist riots - more appropriately defined the relationship between the two religious groups. ${ }^{167}$ Furthermore, DePalma argued that the four Catholic clergy believed that the majority of Protestants in the West would accept their religion and that only a

${ }^{164}$ Ibid., 175.

${ }^{165}$ Margaret C. DePalma, Dialogue on the Frontier: Catholic and Protestant Relations, 1793-1883 (Kent, OH: The Kent State University Press, 2004), xi.

166 Ibid., Xv.

${ }^{167}$ Ibid., 51-52, 141-151. 
minority of the population truly promulgated anti-Catholic sentiments. For example, DePalma argued the following about Archbishop Purcell's tenure in Cincinnati-a city that witnessed intense anti-Catholic demonstrations during the middle decades of the nineteenth century:

Throughout his episcopacy, Purcell displayed a conciliatory attitude toward Protestants and an unwavering belief that the majority of non-Catholics were reasonable people who would accept his church into the larger community. Thus he avoided controversy whenever possible and usually sought a quieter, more diplomatic way to resolve the issues that divided the two sects. ${ }^{168}$

Not only the attitudes of the clergy but also the fact that Catholicism was " present at the creation"" of the West meant that Protestants did not consider the Church "a foreign element."169 According to DePalma, the violent nativist and anti-Catholic demonstrations that riddled New England occurred because the established Protestant populace opposed Catholic immigrants who arrived from Ireland and the German states. Thus, DePalma argued that because Catholics and Protestants settled in the West at the same time they avoided intense and prolonged periods of violence and religious confrontation. ${ }^{170}$ In his study of French Catholic missionaries in the trans-Appalachian West, Michael Pasquier demonstrated that Catholics who settled in frontier Kentucky and Mississippi understood that learning how to survive through assimilation into a Protestant-dominated country proved necessary for the perseveration of the Church in the United States. Unlike the Anglo-Catholics who had resided in Maryland since the colonial period, the French missionary priests encountered not only an intensely Protestant culture but also an entirely new environment on the antebellum frontier.

\footnotetext{
168 Ibid., 89.

169 Ibid., xiv-Xv.

${ }^{170}$ Ibid.
} 
Pasquier's study analyzed how the French priests dealt with their missionary experiences in the early American West, noting that many of them expected a "success story on par with the romanticized tales of saints and martyrs of the colonial past" only to experience "physical, emotional, and material distress." ${ }^{171}$ According to Pasquier, many of the French missionaries dealt with the frustrations of life on the frontier by sharing their experiences with fellow clergy in the United States and abroad. The "confrères" offered "guidance, reassurance, and affection" as the missionaries dealt with scandalous clergy, stubborn laity, and a hostile Protestant population who often questioned their faith and Church doctrine. ${ }^{172}$ In addition to the support of confrères, the priests found comfort in understanding their adverse experiences as part of devotional Catholicism. Attaining popularity among Church officials in the early-nineteenth century, devotional Catholicism viewed "suffering as a source of strength."

As the missionaries carried the Church into the western and southern frontiers, the French priests and other Catholic clergy adapted to the established social, political, and cultural contexts. Pasquier argued that it is important for historians to think about the establishment of Catholicism in the United States as a "lived religion"” rather than a monolithic experience for the entire country that merely involved the transference of Roman Catholic doctrine and dogma to the New World. ${ }^{174}$ As he explained, scholars must:

recognize the unsettled, unscripted, and unofficial thoughts and actions of French missionary priests as they attempted to create a settled, scripted, and official

${ }^{171}$ Michael Pasquier, French Missionaries and the Roman Catholic Priesthood in the United States, 1789-1870 (New York: Oxford University Press, 2010), 59.

${ }^{172}$ Ibid., 46, 58-87.

173 Ibid., 73-82.

${ }^{174}$ Ibid., 7. 
Catholic way of life. In other words, it is important to portray priests less as perfect representatives of a static Catholic Church and more as contributors to a common Catholic culture composed of lay and ecclesiastical persons with varying degrees of cultural capital. ${ }^{175}$

Part of the "lived religion" of French priests who established the Church in the antebellum South was slavery. Although antislavery sentiments gained support within the European Church during the antebellum period, the southern clergy defended slavery because the French priests "identified themselves as both foreign missionaries bent upon the Catholic evangelization of a non-Catholic nation and pastoral protectors of a southern way of life."176 The French missionaries not only accepted slavery but they also participated in the institution by purchasing slaves to perform tasks, such as the construction of churches, seminaries, convents, and schools. Furthermore, the French priests denounced abolitionism as a product of northern Protestantism that threatened the order and stability of the nation. According to Pasquier, the priests' insistence on the maintenance of both "southern social order" and "a Catholic order . . . ensured that most French missionaries did not challenge the fundamental belief that slavery could be good for society if implemented properly."177 In fact, "the more French missionaries acted according to their understanding of Catholicism," argued Pasquier, "the more many of them identified with southern culture and defended the institution of slavery." 178

\section{Catholicism and American Slavery}

Prior to Pasquier's work on Catholic missionaries, Madeleine Hooke Rice authored the first significant work on the American Church and slavery. Published in
175 Ibid.
176 Ibid., 170.
177 Ibid., 187.
178 Ibid. 
1944, American Catholic Opinion in the Slavery Controversy offered an apologetic portrayal of the Church because she argued that slaves received better treatment in Catholic countries and colonies compared to those in non-Catholic regions. Regarding the political scene before the Civil War, Rice claimed that the American Church denounced abolitionism, choosing instead to promote a plan for gradual emancipation. Although Rice applauded the Church for their treatment of slaves, the author showed no sympathy for American clergy who, she believed, failed to face the moral questions of slavery during the Civil War. Rice charged that slavery promulgated racial inequality, which she considered "contrary to the teaching of Catholicism and deserving of condemnation as a moral wrong." ${ }^{179}$ Thirty years after the publication of Rice's work, Maria Caravaglios authored The American Catholic Church and the Negro Problem in the XVIII-XIX Centuries. Similar to Rice's conclusions, Caravaglios noted how the majority of Catholics in both the North and the South condemned abolitionism; however, secession caused an internal rift within the American Church as clergy and laity supported opposing sides during the war. Regarding the American Church's support of African Americans, Caravaglios argued that Catholic officials lacked the necessary resources to properly minister to slave populations in the South. Catholic missionaries and women religious also encountered intense resistance from their Protestant neighbors, the majority of whom opposed the education of African Americans. Caravaglios also

${ }^{179}$ Madeleine Hooke Rice, American Catholic Opinion in the Slavery Controversy (New York: Columbia University Press, 1944); Wimmer, 73. 
claimed that members of the Church exhibited their own racial prejudices, which the author attributed to the social contexts of nineteenth-century America. ${ }^{180}$

A historian of United States history from the Ludwig Maximilian University in Munich, Germany, Michael Hochgeschwender has published the most recent and comprehensive analysis of the American Church's relationship with slavery. In his work, Hochgeschwender demonstrated that "Catholics, whether priests and bishops or laity, were never as concerned about questions of race and slavery in themselves as they were about how race and slavery affected their integration into American society." Ultimately, Hochgeschwender argued that American Catholics—both native-born and immigrant-interpreted and responded to the antebellum crisis over slavery in ways they believed would positively influence the Church's integration into nineteenth-century America. As Hochgeschwender explained, American Catholics opposed the abolitionist movement because of its connection to northern evangelical Protestants. Catholic antiabolitionism — or anti-reform in general—served the purpose of defending the Church against a Protestant populace who argued that Catholics could and should not be American citizens. Hochgeschwender also explained why Catholics supported overwhelmingly the Democratic Party. Democrats not only courted immigrant voters, but the party also opposed the Whig, Know Nothing, and Republican Parties - the three

${ }^{180}$ Maria Genoino Caravaglios, The American Catholic Church and the Negro Problem in the XVIII-XIX Centuries (Charleston, SC: published by Ernest L. Unterkoefler, 1974).

${ }^{181}$ Mark Noll, review of Wahrheit, Einheit, Ordnung: Die Sklavenfrage und der amerikanische Katholizismus 1835-1870, by Michael Hochgeschwender, Theologische Literaturzeitung 133 (2008): 834; Michael Hochgeschwender, Wahrheit, Einheit, Ordnung: Die Sklavenfrage und der amerikanische Katholizismus 1835-1870 (Paderborn: Ferdinand Schöningen, 2006). Due to the author's inability to read German at this time, this thesis relies exclusively on the contents of Noll's review 
parties which were affiliated with antislavery and anti-Catholic platforms during the antebellum, Civil War, and Reconstruction periods. Furthermore, specifically for German and Irish Catholics in the United States, anti-abolitionism proved synonymous with anti-European reform. By 1860, Irish-Americans opposed the Republican Party because of its antislavery politics, which the Irish associated with British abolitionism; and many German Catholics in the United States disparaged the party of Lincoln because it contained members who supported the 1848 liberal revolutions in Europe. ${ }^{182}$ Overall, the American Church opposed the Republican Party and its predecessors during the Civil War era because the Church's "main goals" during the period included the preservation of "Wahrheit, Einheit, [and] Ordnung"- truth, unity, and order. ${ }^{183}$

\section{The Religious History of the Civil War}

Although several works have explored how different religious groups_including both Catholics and Protestants - viewed slavery during the antebellum period, only a few studies have analyzed how the various religious groups interpreted and grappled with secession and civil war. In fact, the first monograph focusing specifically on the study of religion during the war years appeared in 1998. Edited by American religious historians Randall Miller, Harry S. Stout, and Charles Reagan Wilson, Religion and the American Civil War provided a collection of sixteen essays that spanned a range of topics, including the division of the Protestant sects in the 1840s, the role of ministers during the war, the development of a wartime religious press, the effects of war on the faith of women, and the emergence of a Lost Cause "civil religion" in the post-war South. Overall, the collection sought to demonstrate that "religion stood at the center of the

\footnotetext{
${ }^{182}$ Noll, review of Wahrheit, Einheit, Ordnung, 834-836.
}

${ }^{183}$ Ibid., 835. 
American Civil War experience," despite the fact that most scholars had previously ignored its role in the conflict. ${ }^{184}$

Of the sixteen essays, only Randall Miller's article dealt specifically with American Catholics, and he focused on the 145,000 Irish laity who enlisted in the Union Army. Miller underscored a transition in the sentiment of the northern Irish, who rallied behind the Union cause in 1861 only to oppose the war during its last three years. As Miller explained, the "turning point" came in September 1862 following the Battle of Antietam, when President Abraham Lincoln issued his preliminary Emancipation Proclamation. ${ }^{185}$ Many of the northern Irish had initially enlisted to fight against the South because they understood the British to be Confederate sympathizers, and as Miller explained, "to be anti-British was to be Catholic."186 As long as the war was being fought solely for the preservation of the Union, the Irish could justify their enlistment in the Union Army as not only a way to undermine the British but also to demonstrate loyalty to their adopted country. However, once the war involved emancipation and the enlistment of African American soldiers, Irish-American support for the war waned.

"The redefinition of the war in 1862-1863," which included emancipation combined with conscription, "created a sense of betrayal that fueled the Irish Catholics' doubt about the need to serve." 187

Nine years after Religion and the American Civil War, Robert J. Miller published a work similar in organization and content. Essentially, Miller provided historians and

${ }^{184}$ Randall M. Miller, Harry S. Stout, and Charles Reagan Wilson, Religion and the American Civil War (New York: Oxford University Press, 1998), 4.

${ }^{185}$ Ibid., 277.

186 Ibid., 273.

187 Ibid., 281. 
the general public with an updated and more manageable version of the collection of essays edited by Randall Miller, Stout, and Wilson. Nonetheless, Robert J. Miller's Both Prayed to the Same God: Religion and Faith in the American Civil War made some original and important contributions to the historiography. Rather than including only one chapter about Catholics during the war, Miller's work integrated the religious group throughout each theme that he discussed. In addition to describing the contributions of Irish Union soldiers, Miller examined the wartime experiences of Catholic chaplains from both armies. The American Church struggled throughout the war with providing enough chaplains to serve Catholics soldiers, who, unlike their Protestant counterparts, required the regular distribution of holy sacraments, such as communion and penance. ${ }^{188}$ Miller also discussed the contributions of Catholic women religious, who served as wartime nurses and provided care for both Union and Confederate soldiers. Miller suggested that the services of Catholic nuns may have helped break down many of the anti-Catholic prejudices that Protestants expressed before the war. As he explained, "perhaps only one group of religious people achieved such hard-earned, deeply appreciated respect from soldiers and officials of both sides as Roman Catholic nuns."189 More recent studies of Catholics during the war have parroted Miller's conclusions. For example, William B Kurtz argued that the role of Catholic women religious constituted the Church's "most

${ }^{188}$ Robert J. Miller, Both Prayed to the Same God: Religion and Faith in the American Civil War (Lanham, MD: Lexington Books, 2007), 31-40, 97-120.

${ }^{189}$ Ibid., 91, 85-93. 
positive and meaningful [contribution] for changing non-Catholics' views about their religion during the war." 190

In 2006, Mark Noll authored The Civil War as a Theological Crisis, which proved an expanded version of his essay in Religion and the American Civil War. According to Noll, the "political standoff that led to war" in April 1861 "was matched by an interpretive standoff' between those who believed that the Bible condemned slavery and those who claimed that scripture condoned the institution. ${ }^{191}$ Noll's work suggested that because "[n]o common meaning [about slavery] could be discovered in the Bible" the sectional crisis intensified leading the nation to civil war. ${ }^{192}$ In addition to a failed consensus on what the Bible said about slavery, Americans also diverged on their understandings of divine providence. As Noll demonstrated, many Americans in the North and the South went to war in 1861 believing that God had ordained their cause as just and righteous. And as the war continued, Americans turned to providence in order to make sense of the mounting human and environmental carnage. Nonetheless, Noll argued that providential thinking also proved a casualty of the war because many Americans turned toward a more secular or pragmatic approach to law and society during the post-war period. ${ }^{193}$

Although much of Noll's work dealt with evangelical Americans, noting that "American religion was still mostly Protestant" in the 1860 s, the author included a

${ }^{190}$ William B. Kurtz, "Roman-Catholic Americans in the North and Border States during the Era of the American Civil War," PhD dissertation, University of Virginia, 2012, 14.

${ }^{191}$ Mark A. Noll, The Civil War as a Theological Crisis (Chapel Hill: The University of North Carolina Press, 2006), 4.

192 Ibid., 4, 31-50.

193 Ibid., 75-94. 
chapter about the wartime perspectives of Catholics—both American and European. ${ }^{194}$ Stating the importance of understanding the Catholic viewpoint(s) during the era, Noll remarked: "Catholic engagement with issues like the Bible and slavery is particularly instructive for the more general state of theology because Catholics were able to raise possibilities beyond the imagination of American Protestants. ${ }^{195}$ Noll's analysis of how Catholic intellectuals, both lay leaders and Church officials, viewed slavery, emancipation, secession, and civil war demonstrated that an additional perspective of the era existed, albeit one that developed outside of the mainstream Protestant consensus. Unfortunately for scholars interested in the American Church, Noll's chapter focused primarily on foreign Catholic interpretations because the author claimed that American Catholic assessments of the war were not "as fully developed as Catholic commentary from abroad." ${ }^{\text {196 }}$ Although European Catholics were divided between liberals—who supported antislavery measures - and conservatives — who questioned "the supposed virtues of modern society"- both groups concluded that the war had been spawned by the fallacies of Protestantism. ${ }^{197}$ As Noll explained, European Catholics believed that "a Protestant heritage [had] left Americans without a trusted arbitrator who could adjudicate such differences of opinion [about slavery]. ${ }^{, 198}$ Although members of the European Church agreed that the "Bible was certainly the true and authoritative word of God," they argued that "without the magisterium of the Roman Catholic Church to guide
${ }^{194}$ Ibid., 11.
195 Ibid., 125.
196 Ibid.
197 Ibid., 138.
${ }^{198}$ Ibid., 155. 
interpretation of the Bible, Americans were doomed to suffer the ill effects of excess democracy, excess republicanism, and excess Protestant individualism.”199

Interestingly, David Goldfield's recent history of the Civil War era expounded arguments similar to those coined by European Catholics in the 1860s. Referring to the war as "America's greatest failure," Goldfield argued that "the invasion of evangelical Christianity into the political debate" during the antebellum period made compromise between northerners and southerners impossible and led the nation to civil war. ${ }^{200}$ According to Goldfield, "evangelical doctrine" taught that the interpretation of scripture remained the "right and responsibility" of each individual; nonetheless, this proved particularly dangerous if Americans applied the "religious standard . . to politics" because that made "each person a law unto himself."201 Thus, Goldfield explained the Civil War as a product of the schism within American evangelical Christianity. Northern evangelicals sought to purify the nation by eliminating slavery, which they interpreted as a moral evil condemned by the Bible; and southern evangelicals considered their northern counterparts religious fanatics who distorted scripture because they believed that God had ordained the institution of slavery and African American subordination. Members of both sections perceived their interpretations of scripture as right, just, and the word of God. Thus, as Goldfield explained, "Evangelical Christianity polarized political debate . . poisoned the democratic process," and eroded the center, allowing "[religious] extremists on both sides" to gain popularity. ${ }^{202}$

199 Ibid.

${ }^{200}$ David Goldfield, America Aflame: How the Civil War Created a Nation (New York: Bloomsbury Press, 2011), 3.

${ }^{201}$ Ibid., 7.

202 Ibid., 3, 7. 
American Catholics also assumed an important place in Goldfield's analysis of the period. Before slaveholders became the targets of northern evangelicals, demonstrations occurred throughout the North that branded Catholics as the group that threatened the future of American society. Similar to W. Jason Wallace's work, Goldfield demonstrated the interconnectedness of the anti-Catholic and antislavery movements following the $1830 \mathrm{~s}$, as northern evangelicals portrayed them as the "Two Despotisms" within the United States. ${ }^{203}$ By the start of the war, American Catholics perceived the Republican Party as anti-Catholic because many of its members not only subscribed to evangelical Christianity but had belonged to the Know Nothing Party during the mid-1850s. According to Goldfield, some supporters of the Union cause "felt than once the Union won the war against slavery, the next conflict would be against the Roman Catholic population." ${ }^{204}$ Many Republicans and Union soldiers believed that “"Catholics, like slaveholders, were opponents of American values; in fact, [many considered Catholics] . . . the next thing to Slavery." 205

To date, George C. Rable has authored the definitive work on religion during the Civil War, in which he argued that:

[the] Civil War had in fact been the "holiest" war in American history. Never before and likely never again would so many ministers, churches, and ordinary people turn not only to their Bibles but to their own faith to explain everything from the meanings of individual deaths, to the results of battles, to the outcomes of the war itself. ${ }^{206}$

203 Ibid., 151.

${ }^{204}$ Ibid., 293.

205 Ibid.

${ }^{206}$ George C. Rable, God's Almost Chosen Peoples: A Religious History of the American Civil War (Chapel Hill: The University of North Carolina Press, 2010), 397. 
As Rable explained, Civil War-era politicians, soldiers, and civilians interpreted the war through a religious lens because they lived in an intensely Protestant world. Beginning in the early-nineteenth century, the Second Great Awakening created a social and cultural context in which "religion deeply influenced" Americans' understandings of their lives and their environment. ${ }^{207}$ During the antebellum and Civil War periods, religion pervaded essentially every aspect of American society, including political debates. Thus, when the question over the expansion of slavery thrust the nation into a political crisis during the 1850s, politicians, religious leaders, and laymen utilized the Bible and their faiths to either criticize or vindicate human bondage. ${ }^{208}$ Nevertheless, Rable argued, this proved to be a "problem" because "[r]eligious faith offered no solution to these issues [slavery], or at least no solution that could win support across racial and sectional lines."209

Although a reliance on faith and scripture had undoubtedly contributed to disunion and war, most Americans did not denounce their religious beliefs after April 1861. Conversely, northerners and southerners turned to faith and a trust in providence to help them make sense of the conflict. As Rable demonstrated, many of the letters that soldiers wrote home to family members, friends, and loved ones described how they understood victory, defeat, starvation, or imprisonment as products of divine will. As the war continued, many soldiers grew closer to God as evidenced by the camp revivals that occurred from late 1862 until the end of the war. Nevertheless, some-particularly those

\footnotetext{
${ }^{207}$ Ibid., 12.

208 Ibid., 11-50.

209 Ibid., 21.
} 
in the Confederacy who experienced defeat during the war-turned away from their faith and expressed antipathy toward religion overall. ${ }^{210}$

Furthermore, references to Catholicism can be found throughout Rable's work, as he analyzed the experiences of the laity who fought during the war, chaplains who accompanied Catholic units into battle, and members of the American hierarchy who struggled to keep their religious institutions operational amidst the calamities of the national crisis. Similar to Robert J. Miller and Kurtz, Rable argued that the services of Catholic nuns tempered the anti-Catholic sentiments held by the majority of American Protestants. In addition to the work of women religious, Catholic chaplains also provided religious and emotional comfort to soldiers of both faiths, despite their struggles to obtain the necessary resources for their ministry. As Rable explained, Catholic chaplains often crafted makeshift altars and utilized whatever items that they could obtain in order to hold religious services for their soldier congregations. ${ }^{211}$ Regarding the politics of waremancipation, conscription, and civil liberties issues—Rable showed how American Catholics did not maintain a monolithic perspective. Although nearly all Catholics in the South and Border States opposed Republican policies, Church clerics and laity in the North took a variety of stances about the issues. Archbishop John Hughes of New York and Archbishop John Baptist Purcell of Cincinnati openly endorsed emancipation and conscription, while the majority of the northern Irish laity opposed the policies of the Lincoln administration. Rable also described many of the challenges faced by members of the American hierarchy. In addition to suffering from a shortage of chaplains and women religious to serve Catholic soldiers and displaced slaves, archbishops and bishops

\footnotetext{
${ }^{210}$ Ibid., 51-68, 185-239, 299-334.

211 Ibid., 120-131, 169-170, 211-213.
} 
also dealt with the demands of military leaders who were stationed in their dioceses. For example, Bishop Augustin Verot of Savannah protested the construction of a Union defensive line that ran through a Catholic cemetery in the city. Verot petitioned United States Secretary of War Edwin Stanton, who ordered the defensive line rerouted after a lengthy exchange of letters with Verot. ${ }^{212}$

Since the publication of Rable's important work, Timothy Wesley has contributed a volume about the issues related to political ministers during the war. Although the works by Noll, Miller, and Rable showed how political preaching played a prominent role in bringing about the sectional crisis, secession, and war, the authors did not fully explore how political preaching influenced the years after Fort Sumter. However, Wesley's The Politics of Faith during the Civil War analyzed the role of political ministers — both Catholic and Protestant—-following the spring of 1861. According to Wesley, ministers served as community leaders during the nineteenth century; therefore, congregations expected their pastors or priests to help guide them through the conflict. Not only did the laity desire spiritual and political guidance but they also anticipated that their religious leaders would reassure them that their cause was righteous and the work of God. ${ }^{213}$ Although he dedicated one chapter to Confederate ministers, most of The Politics of Faith during the Civil War examined the experiences of religious leaders in the North, where opposition to the war proved a major concern for ardent Unionists. Wesley noted that most northern ministers supported the Union cause; however, several priests and pastors who refused to fly the American flag from their churches or failed to

212 Ibid., 191-198, 226-331, 265-266, 323-328.

213 Timothy L. Wesley, The Politics of Faith during the Civil War (Baton Rouge: Louisiana State University Press, 2013), 8-42. 
follow through with loyalty oaths raised the suspicions of the federal government and, often times, their own congregations. During the war, federal forces arrested some northern ministers who they suspected of disloyalty. As Wesley explained, most of those whom the Union Army imprisoned supported the Democratic Party and publicly denounced Lincoln and his pro-war policies. Wesley also described how several congregations practiced self-policing by removing ministers whom they suspected of treasonous activity. According to Wesley, ministers who refused to display patriotic banners or publicly denounce secession not only raised questions about their own loyalty but also that of their congregations; as a result, many laymen refused to take the risk of their own arrest and either forced their religious leaders to adhere to a pro-war stance or removed them from their positions. ${ }^{214}$

As Wesley demonstrated, the war proved a particular conundrum for ministers who subscribed to apolitical preaching. Pastors and priests who endorsed neutrality often drew the attention of the Union Army. This remained a problem throughout the war in the Border States, where loyalties were divided and anyone who did not proclaim unconditional support for the Union was often perceived to be a Confederate sympathizer. Referred to as separate-spherists, apolitical ministers believed in the complete separation of religion and politics. Separate-spherits contended that they dealt only with the spiritual, thus they should remain uninvolved with any secular or political issues, dilemmas, or controversies. In addition to separate-spherits, Wesley noted that many Civil War-era clerics adhered to the policy of separate-duty ministry. Separateduty ministers believed that they should opine about the moral issues of the war, such as

${ }^{214}$ Ibid., 43-91. 
slavery, but contended that their opinions did not constitute public endorsement of a particular political party or cause. Finally, separate-component preachers argued that the religious, moral, and political issues of the war could not be separated. According to Wesley, most separate-component clerics adhered to a millennial perspective of the war. As a result, separate-component ministers, like Henry Ward Beecher, believed they should support the Union war effort in order to eliminate slavery — a moral evil—-from the nation. ${ }^{215}$

\section{American Catholics and the Civil War}

Although all of the works about religion during the Civil War published since 1998 have included some analysis of American Catholics, only a few book-length works have been published that focus solely on the American Church — in both the North and the South-during the war. In addition to Wimmer's dissertation, Benjamin J. Blied's Catholics and the Civil War served as the first and remains the only comprehensive published work on the subject. In Catholics and the Civil War, Blied covered a wide array of topics, including the state of Catholicism in the nation prior to the Civil War, the Church's stance toward slavery and abolitionism, the wartime opinions of bishops in the North and the South, the viewpoints of the American-Catholic press during the conflict, Union and Confederate diplomatic relations with Europe and the Vatican, and the charitable work of Catholics during the war.

Similar to the arguments made by Church historians during the first half of the twentieth century, Blied contended that American Catholics attempted to remove themselves from the political crisis during the antebellum period. Furthermore, Blied

215 Ibid., 93-121. 
suggested that Protestantism had divided the nation and led Americans to secession and war in 1861. Regarding the Catholic position toward slavery, Blied posited that although "the abolition movement may be characterized as a good cause . . . It was furthered by revolutionary characters, radical thought, and illegal activity. [Therefore,] Catholics could not associate themselves with such a movement."216 According to Blied, "Catholics [had] always disliked slavery," but the Church supported a plan for gradual emancipation rather than the abolitionists' design for an immediate end to the institution. ${ }^{217}$ Furthermore, Blied contended that the environment in which Catholics lived proved critical to the development of individual opinions, sympathies, and interpretations once the war began. Although the American Catholic Church did not divide into northern and southern branches, Catholics held varying opinions about slavery, disagreed on the constitutionality of secession, and fought for opposing armies during the war. According to Blied, Catholics in both the North and the South deemed it important to demonstrate patriotism and allegiance to their respective causes because Catholic loyalty to the United States had been questioned by Protestants throughout the antebellum period. Although the majority of Catholics in the North supported the Union and those in the South backed the Confederacy, the Church escaped division because "in her [the Church's] eyes the problems of the day were insignificant compared to the eternal values."218 Essentially, Catholics considered the issues of slavery, secession, and the war to be political or secular concerns that could not and should not interfere with

${ }^{216}$ Benjamin J. Blied, Catholics and the Civil War (Milwaukee, WI: privately published, 1945), 34 .

217 Ibid., 21.

218 Ibid., 69. 
"their devotion to the Church." ${ }^{219}$ Catholics and the Civil War also underscored the charitable work performed by members of the Church. Specifically, Blied noted three ways in which Catholics offered charity to soldiers: the service of chaplains, the publication of religious literature, and the medical care of women religious in military hospitals. According to Blied, the charitable work of Catholics proved more righteous than the contributions of Protestants because Catholics provided services to members of all faiths. As the author explained: "From the standpoint of charity the work of the Catholic sisterhoods stands out even more boldly if it is remembered that they served Catholics and Protestants alike despite the lurid calumnies about convents which were so popular before the war."220

In addition to Blied's book, Robert J. Murphy and Robert Emmett Curran have authored article-length analyses about the American and European Catholic Churches during the Civil War. Published in 1928, Murphy's article was primarily concerned with justifying the American Church's position toward slavery during the nineteenth century. According to the author, Catholics had tolerated slavery throughout Church history; therefore, neither American nor European Catholics deemed emancipation during the Civil War necessary or beneficial to the African American population. Murphy argued that Catholic anti-abolitionism created a political alliance between the American Church and the Democratic Party, which allowed Church members to combat political nativism. According to Murphy, the American Church maintained a silent or aloof posture once the secession crisis and war began because Catholics concentrated on staving off anti-

\footnotetext{
219 Ibid.

${ }^{220}$ Ibid., 117.
} 
Catholic prejudices and growing the Church during the period. ${ }^{221}$ Robert E. Curran's more recent article showed how Catholic opinions in Europe shifted from openly proUnion in 1861 to anti-war after 1863. As war broke out in the United States in the spring of 1861, Pope Pius IX faced attacks by Italian nationalists who sought to unite Italy and overthrow the pope's temporal powers. According to Curran, Rome's experience "with its own insurrection" led Pope Pius IX and other officials of the Holy See to sympathize with the Union "in affirming the right of self-defense against rebellion."222 In fact, the Vatican hoped the Union would quickly restore order within the United States so that the country could serve as an ally to the Holy See in its war against liberal revolutionaries. However, as the war entered its third year, Lincoln's Emancipation Proclamation signaled to the Holy See that the North had abandoned a war for the restoration of the Union. After 1863, Pope Pius IX and his officials considered the Union war effort the work of radical liberals who supported "slaves murdering defenseless women and children in the Deep South."223 As Curran explained, the "very government that had justified its call for volunteers on the grounds of putting down an insurrection now appeared to be consorting in servile insurrection ... The North's commitment to abolish slavery seemed then, from Rome, to be cynically self-serving and hypocritical.",224 Beginning in the fall of 1862, the attitudes of the Holy See shifted from a pro-Union stance to sympathy for the Confederacy, largely because Vatican officials believed that

${ }^{221}$ Robert Joseph Murphy, "The Catholic Church in the United States during the Civil War Period: 1852-1866," Records of the American Catholic Historical Society 39 (December 1928): 271-346; Wimmer, 64-66.

${ }^{222}$ Robert Emmett Curran, Shaping American Catholicism: Maryland and New York, 1805-1915 (Washington, DC: Catholic University of America Press, 2012), 103.

223 Ibid., 104.

224 Ibid. 
"the Confederates, once they gained independence, would work out a peaceful solution to the issue [of slavery]" and restore order in the United States. ${ }^{225}$

Max Longley has authored the most recent monograph about the American Church in the North during the Civil War. Titled For the Union and the Catholic Church: Four Converts in the Civil War, Longley's book examined the lives of William and Sylvester Rosecrans, James Healy, and Orestes Brownson—four individuals who joined the Catholic Church during the antebellum period and assumed important positions in the North during the Civil War. Much of Longley's analysis dealt with the pre-war period, describing how the four converts grappled with the intensely antiCatholic context of mid-nineteenth century America. Because the four converts came from different backgrounds and entered different professions, Longley was able to explore various themes and elements of American Catholicism in his work. After graduating from West Point, William Rosecrans joined the Catholic Church in 1845. During the Civil War, he ascended to the rank of major general in the Union Army and commanded forces in the western theater of the war. Through his analysis of William Rosecrans, Longley examined the experiences of Catholic soldiers during the war and explored how Rosecrans's faith influenced his interpretation of the conflict. Unlike most northern Catholic soldiers, Rosecrans proved both devoutly Catholic and a supporter of emancipation and the Lincoln government. ${ }^{226}$ Sylvester Rosecrans shared his brother's wartime sympathies. As a priest in the Archdiocese of Cincinnati, Sylvester Rosecrans aided his metropolitan, Archbishop John Baptist Purcell, and his brother and editor of the

225 Ibid.

${ }^{226}$ Max Longley, For the Union and the Catholic Church: Four Converts in the Civil War (Jefferson, NC: McFarland Publishing, 2015), 21-27, 203-230. 
Catholic Telegraph, Father Edward Purcell, in promoting emancipation and a Union victory in the war. Prior to being ordained a priest, Sylvester Rosecrans attended seminary in Rome. Longley used Rosecrans's experiences in Europe as a lens through which to explore how American Catholics interpreted the European revolutions of 1848. While living in Rome, Rosecrans witnessed attacks led by Italian nationalists who forced Pope Pius IX to flee to Naples in 1848. Rosecrans and other American Catholics united in support of the pope, while Protestants in the United States backed the revolutionaries. $^{227}$

The experiences of James Healy allowed Longley to analyze the Church's relationship with race and slavery. The son of a planter and slave from Georgia, James Healy converted to Catholicism after being educated at Holy Cross College in Boston. According to Longley, Healy's father brought James and his siblings to Boston because Georgia law deemed the children "bastards." 228 As a wealthy planter, Michael Healy could afford to educate his children in the North. After graduating from Holy Cross College, James Healy wanted to join the Society of Jesus (Jesuits); however, according to canon law "only men born in lawful wedlock could be ordained as priests." 229 No official record existed to indicate that Healy's parents—a slaveholder and his slave—-had been married in the Church. Although Georgia law prohibited marriage between whites and blacks, the "racial difference" between Healy's parents "was not a problem in the eyes of the Church. ${ }^{230}$ In fact, the Church often recognized informal marriages between mixedrace couples as a way of ensuring that the Church did not come under scrutiny from the

${ }^{227}$ Ibid., 28-47, 168-183.

${ }^{228}$ Ibid., 50.

${ }^{229}$ Ibid., 63.

${ }^{230}$ Ibid., 64. 
white community for allowing an ordained priest to officiate an interracial union. James Healy convinced Bishop Fitzpatrick of Boston that his parents had married, and the cleric granted Healy permission to enter the seminary. ${ }^{231}$ Longley dedicated much of his volume to an analysis of Orestes Brownson, the newspaper editor who had been a Universalist, Unitarian, and Transcendalist before converting to Catholicism. Similar to the Rosecranses, Brownson proved an ardent Unionist throughout the war, recommending emancipation, supporting the arrest of disloyal citizens, and endorsing conscription. Interestingly, Longley utilized the viewpoints of Brownson to underscore the difference in ultramontanism and Gallicanism within the American Church. According to Longley, Brownson proved an ultramontane because he argued in his Quarterly Review that the pope should have additional authority in temporal affairs. Furthermore, Brownson wrote numerous articles advocating that the United States become a Catholic nation, because he believed the problems of the antebellum period could be resolved if all Americans received the spiritual guidance of the Church. Although a member of the laity, Brownson's ultramontane sentiments drew the attention of several members of the American hierarchy. Archbishops John Baptist Purcell and other American Gallicanists thought Brownson's editorials brought unwarranted attention on the Church and incited anti-Catholic sentiments during the pre-war period. ${ }^{232}$ Irish-American Catholics during the Civil War

No ethnic group contributed more to the growing population of the American Church during the Civil War era than the Irish. As the Irish arrived in the United States from Europe during the decades before the war, they maintained communication with

\footnotetext{
231 Ibid., 50-64.

${ }^{232}$ Ibid., 65-79, 85-100, 122-144, 156-167, 233-236.
} 
their brethren in Europe and continued to be informed and concerned about European and trans-Atlantic politics. In fact, one of the first works to evaluate the Irish involvement during the Civil War focused on the dissimilarity between American-Irish and EuropeanIrish viewpoints. Although the majority of Irish-Americans fought for the Union, European-Irish overwhelmingly sympathized with the Confederacy. According to Joseph M. Hernon's Celts, Catholics and Copperheads: Ireland Views the American Civil War, leading European-Irish conservatives identified with the planter elites of the Confederacy, and viewed the South's struggle against the Union as synonymous with Ireland's struggle for independence from Great Britain. Although Hernon showed that initial support during the war divided the American- and European-Irish, the two groups unified in opposition to the Lincoln administration after 1863. The majority of Irish on both sides of the Atlantic opposed Lincoln's Emancipation Proclamation; thus, American-Irish support for the Union waned once the war involved not only the preservation of the Union but also emancipation. ${ }^{233}$ A more recent examination of the Irish in a trans-Atlantic context revealed the interconnectedness of the antislavery and Irish repeal movements during the 1840s. According to Angela F. Murphy, members of repeal associations in Ireland and the United States considered endorsing both a revocation of the Act of Union and abolition; however, American-Irish proved unwilling to support the antislavery movement. As Murphy explained, the Irish distrusted abolitionists because of their association with anti-Catholicism, and over time the British

${ }^{233}$ Joseph M. Hernon, Jr., Celts, Catholics and Copperheads: Ireland Views the American Civil War (Columbus: Ohio State University Press, 1968). 
association with abolitionism led the majority of Irish in the United States and Europe to view Irish repeal and anti-abolitionism as symbiotic movements. ${ }^{234}$

Much of the recent scholarship about Catholicism during the Civil War has focused on the Irish laity who fought for the Union. Scholars have analyzed how the military service of Irish Catholics affected their assimilation into American society, as well as explored the views of Irish-Americans toward secession and emancipation. Several historians have underscored the prejudice Irish-Americans demonstrated against blacks, fearing that if emancipation transpired they would have to compete with newly freed African Americans for employment. However, rather than focusing on the racist attitudes that many Irish-Americans exhibited toward African Americans or the class conflict that developed between the two groups, Christian G. Samito argued that the Irish and blacks in the United States shared a common struggle to expand concepts of citizenship during the Civil War period. According to Samito, both groups utilized their military service as evidence that they should be included alongside white, native-born Americans as citizens of the United States. In particular, Samito contended that the Irish used narratives of their bravery and loyalty in the Union Army to combat nativist and anti-Catholic sentiments that remained prevalent in the antebellum, Civil War, and postwar periods. $^{235}$ In addition to using the conflict as an opportunity to obtain citizenship, the Irish, according to Brian Danver, considered participation in the Civil War as a way

${ }^{234}$ Angela F. Murphy, American Slavery, Irish Freedom: Abolition, Immigrant Citizenship, and the Transatlantic Movement for Irish Repeal (Baton Rouge: Louisiana State University Press, 2010).

${ }^{235}$ Christian G. Samito, Becoming American Under Fire: Irish Americans, African Americans, and the Politics of Citizenship during the Civil War Era (Ithaca, NY: Cornell University Press, 2009). 
of achieving "the American Dream of upward mobility."236 In his study of Irish soldiers, Danver explored the struggles they experienced arriving to and settling in the United States, their hardships in combat, and their frustrations about conscription and the changing course of the war, which were best exhibited during the New York City draft riots of 1863. Similar to Samito, Danver indicated that Irish-Americans considered their service in battle as sacrifices worthy of obtaining equality and eliminating ethnic and religious prejudices in nineteenth-century America. As Danver explained, "the Civil War is often remembered as the conflict to end slavery;" however, "a close analysis of Irish participation reveals that the struggle embodied much more."237

Although loyal Irish-Americans expected their wartime efforts to eradicate nativism and religious prejudices in the nation, anti-Catholic and anti-Irish sentiments continued during and after the war in the North. William B. Kurtz's recent dissertation on Catholics in the Union during the Civil War analyzed the effect that Catholic participation in the war had on combatting nativism and anti-Catholicism. Although several Irish-Catholic units demonstrated bravery and fought gallantly for the Union, the combat experiences of Catholic soldiers failed to remove xenophobic and anti-Catholic opinions held by the native-born Protestant populace. According to Kurtz, exploits of anti-war Catholics — many of whom were northern Irish — who resisted the draft, opposed emancipation, and chided the Lincoln administration trumped any efforts made by loyal Irish-Americans to help procure a Union victory. Because a unified pro-war Catholic

${ }^{236}$ Brian Danver, "The Fight for the American Dream: Irish-Americans and the Civil War," MA thesis, Georgetown University, 2014, ii.

${ }^{237}$ Ibid., 5. 
opinion never existed in the North, Protestant Americans continued to question the loyalty of American Catholics. ${ }^{238}$

In contrast to Kurtz's analysis of the American-Catholic experience in the North, David T. Gleeson's recent work on the Irish in the Confederacy argued that the Civil War helped usher in Irish assimilation into southern society. Gleeson's work explored the southern Irish experience from their participation in the 1860 presidential election through their contributions during the Lost Cause movement. The majority of southern Irish was located in the Border State cities of Baltimore, Louisville, and St. Louis and supported Democratic candidate Stephen Douglas during the presidential election; thus, most Irish in the South proved reluctant secessionists during the Civil War. Similar to their native-born Protestant brethren, the Irish in the Deep South supported secession following Lincoln's election. However, the Irish in the Upper and Border Souths opposed immediate disunion because they worried about its impact on their economic security as poor white laborers. As Gleeson explained, few Irish owned slaves, but they believed that slavery benefitted them socially and economically as an immigrant-Catholic population attempting to survive in a Protestant-dominated nation. The Republican Party's association with the antislavery and anti-Catholic movements led some Irish in the Border States and the majority of Irish in the Upper and Lower Souths to support the Confederacy. ${ }^{239}$ Furthermore, Gleeson argued that defending their adopted home proved the primary motivation for Irish enlistment in the Confederate military and those who

${ }^{238}$ Kurtz, "Roman-Catholic Americans in the North and Border States," 314-375.

${ }^{239}$ David T. Gleeson, The Green and the Gray: The Irish in the Confederate States of America (Chapel Hill: The University of North Carolina Press, 2013), 10-59. For example, Gleeson approximated that between 500 and 1,000 Irish from Kentucky supported the Confederacy (55-59). 
enlisted wanted to demonstrate bravery in order to challenge any questions about Irish or Catholic loyalty. ${ }^{240}$ Gleeson also showed how Catholic clergy assumed an important role in advocating southern Irish participation in the Confederacy. The Church did not officially condemn slavery, which became widely known among the Irish in the South due to the "Catechism "for the use of Catholics in the Confederate States of America", written by Bishop Augustin Verot of Savannah, Georgia. ${ }^{241}$ Clergy like Verot and Bishop Patrick Lynch of Charleston, South Carolina not only offered southern Irish clarification that their support of the Confederacy did not go against Church teachings about slavery, but many southern clerics also openly supported secession and labored to procure a Confederate victory. According to Gleeson, the efforts of "Irish Catholic bishops, priests, and nuns, as well as some prominent lay spokesmen, left an impression of Irish loyalty to the cause greater than it actually was."242 Compared to Irish Catholics in the North, who failed to demonstrate unified support for the Union war effort, southern Irish Catholics appeared fully committed to Confederate independence due to the efforts of their religious and community leaders. Ultimately, however, the post-war efforts of Irish southerners, who resisted Radical Republican policies and African American assimilation into southern society, "helped seal their position as full members of the 'Solid South.", 243 Irish southerners joined Confederate veterans associations, helped erect Confederate monuments across the South, and contributed to Lost Cause literature,

\footnotetext{
${ }^{240}$ Ibid., 69-111.

241 Ibid., 153.

242 Ibid., 150.

${ }^{243}$ Ibid., 187.
} 
thereby demonstrating that the southern Irish "commemoration of the war was more important that their actual participation in it." 244

\section{$\underline{\text { Conclusion }}$}

Undoubtedly, the history of the American Catholic Church during the Civil War era incorporates scholarship from a variety of academic fields: American and European Church history, immigration and ethnic studies, nineteenth-century literary and cultural studies, antebellum political history, and the religious history of the Civil War. Although only a few book-length works have analyzed exclusively the Church during the period, a number of scholars have included the history of American Catholics in their studies. In doing so, these historians have underscored a number of important themes. First, American Catholics dealt with religious prejudice from the early colonial period until well after the Civil War. Although the degree of anti-Catholic sentiment varied by region and social context, all American Catholics were impacted and influenced by religious hostility between members of the Church and Protestants. Second, historians have demonstrated the interconnectedness of the anti-Catholic and antislavery movements. Because northern evangelical preachers and politicians often constructed their sermons and platforms around the elimination of the "twin evils" of antebellum America, American Catholics found themselves in opposition to both anti-Catholicism and abolitionism. Thus, the majority of American Catholics - from the North and the South — supported the Democratic Party during the antebellum, Civil War, and Reconstruction periods.

${ }^{244}$ Ibid. 
Third, American Catholics were also shaped by developments within the European Church. French missionaries brought a European-Catholic understanding of the world to the antebellum West—which created both unexpected disappointment and opened the way for their assimilation into southern society. Likewise, the nationalist revolutions in Europe during the late 1840s galvanized much of the American hierarchy behind Pope Pius IX and in opposition to liberal reforms not only abroad but in the United States. As a result, attacks against the Church in Europe shaped American Catholic thoughts about how their own society and government should operate. Finally, scholarship that began during the second-half of the twentieth century has worked to upend the perception of the American Church as a monolith during the Civil War era. Although the Church may have assumed an apolitical stance toward slavery and proclaimed neutrality during the war, its members - both clergy and laity — maintained their own, often conflicting, opinions about social and political issues and supported opposing sides during the war. Wimmer's important dissertation demonstrated the variety of American Catholic opinions and interpretations of the Civil War. Although she focused on Church hierarchy, her work stands as a guideline for how scholars interested in American Catholics during the era should approach the topic. As the historiography demonstrated, American Catholics interpreted the Civil War based on understandings of their own faith and Church teachings, the social and cultural pressures of the region in which they lived, their need to survive as either immigrants or members of a religious minority in an intensely nativist and Protestant nation, and in response to the reactionary developments within the universal Church against trans-Atlantic liberalism during the nineteenth century. 


\section{CHAPTER II}

\section{AN ERA OF ANTI-CATHOLICS AND APOLOGISTS: SETTING THE STAGE FOR A RELIGIOUS INTERPRETATION OF THE CIVIL WAR}

"Indeed, whoever is a Catholic," wrote Francis Patrick Kenrick, "is not without

the fear of death ... especially the priests, and, most of all, the Bishop."245 Serving at the time as bishop of the Diocese of Philadelphia, Kenrick wrote to his brother, Peter Richard Kenrick, to inform him about the "threats of murder" and rumors that "rioters would make an attack upon the church of St. Philip" and other Catholic institutions in the city. $^{246}$ During the summer of 1844 , nativist and anti-Catholic riots erupted in Philadelphia due to disputes over which version of the Bible and Ten Commandmentseither the Catholic or the Protestant-would be used in public schools. The Philadelphia riots, which took place during first week of May and July 1844, proved the culmination of nativist fears about the growing Irish Catholic population in the city as well as the perceived threat of Catholicism or "popery" in America. ${ }^{247}$ As Kenrick explained to his brother, "They [the marching mob] carried the American flag before them. All day they had kept the flag raised bearing the placard, a lie, that the Irish and Papists had trampled

${ }^{245}$ Francis Patrick Kenrick to Peter Richard Kenrick, July 10, 1844, in The Kenrick-Frenaye Correspondence: Letters Chiefly of Francis Patrick Kenrick and Marc Antony Frenaye, 1830-1862, edited by F. E. T. (Philadelphia, PA: Wickersham Printing Company, 1920), 195.

246 Ibid.

${ }^{247}$ For more information about the Philadelphia riots of 1844, see: Ray Allen Billington, The Protestant Crusade, 1800-1860: A Study of the Origins of American Nativism (New York: Macmillan Company, 1938), 222-230; Jon Gjerde, Catholicism and the Shaping of Nineteenth-Century America, edited by S. Deborah Kang (New York: Cambridge University Press, 2012), 1-7. 
on it. They shouted threats of death to the Irish."248 In all, the anti-Catholic riots in Philadelphia during the summer of 1844 produced over a dozen deaths and numerous wounded citizens, displaced many Catholic families, and destroyed or burned several Catholic churches and Irish businesses. ${ }^{249}$

A similar event occurred on election day, April 5, 1852, in St. Louis, where nativists and immigrant voters clashed in the streets of the city. Nativists took control of the polls in several German neighborhoods, the mayor summoned the militia to disperse the mobs, and at least one family member of the city's nativist coalition was murdered. ${ }^{250}$ Although it remains unclear which group - the nativists or Germans - initiated the riot, historian Luke J. Ritter argued that "It did not matter; the St. Louis Election Riot of 1852 polarized the political atmosphere of St. Louis between those who blamed the nativists for the political violence and those who blamed immigrants."251 Two years later, election-day violence occurred once more in St. Louis, this time between members of the Know Nothing Party and German and Irish voters. A three-day riot ensued after an "Irish boy stabbed an American in the stomach and a crowd chased him into the Irish district of the city." ${ }^{, 252}$ The Know-Nothing mob, which gained as many as 5,000 rioters, targeted immigrant pubs and Catholic churches in the city, inflicting "hundreds of thousands of dollars of damage on German and Irish businesses and homes" and causing at least ten

${ }^{248}$ Francis Patrick Kenrick to Peter Richard Kenrick, June 2, 1844 [?], in The Kenrick-Frenaye Correspondence, 189-190.

${ }^{249}$ Billington, 222-230; Gjerde, 1-7.

${ }^{250}$ Luke J. Ritter, “Anti-Catholic America: Nativism and Religious Freedom in the Antebellum West," PhD dissertation, Saint Louis University, 2014, 115-121. The citations included in this thesis were drawn from a manuscript version of the dissertation.

${ }^{251}$ Ibid., 122.

252 Ibid. 
deaths. ${ }^{253}$ Although the nativist rioters targeted all immigrants, despite a number of Freethinking and Protestant Germans in the city, Ritter argued that the St. Louis Election Riot of 1854 "retained the quintessentially anti-Catholic character of the nativist movement" in Missouri. ${ }^{254}$

A year after the August 1854 Know-Nothing riot in St. Louis, Bishop Martin John Spalding experienced a comparable event in Louisville. On election day, August 6, 1855, Know-Nothings took control of the polls in the city and an anti-Catholic mob descended upon Spalding's cathedral. The Know-Nothing rioters threatened to burn down the Cathedral of the Assumption because they believed that Church officials had stored weapons inside. In an attempt to restore order and prevent an attack on his church, Spalding penned the following note to John Barbee, mayor of Louisville:

Mr. Mayor, a howling mob is now at my doors. The police either cannot or will not protect us. Here are the keys of the Cathedral. If it be destroyed or damaged to any degree, I shall call the city to account before the bar of justice in yonder Court House and I shall call you to account before the eyes of all civilized men. ${ }^{255}$

Although the cathedral did not suffer damages, nativists burned property in an area known as “Quinn's Row,” where German and Irish tenants resided. Rioters also damaged St. Patrick's Church, one of the Irish-Catholic parishes in Louisville, as well as destroyed Ambrewster's Brewery. ${ }^{256}$ A few days following the violent event - referred to as the Louisville "Bloody Monday" Riot—Bishop Spalding wrote to Francis Patrick Kenrick, then serving as the archbishop of Baltimore:

${ }^{253}$ Ibid.

254 Ibid., 123.

${ }^{255}$ Martin John Spalding quoted in Philip Wayne Kennedy, "Bishop M. J. Spalding and the Know-Nothing Movement in Kentucky," MA thesis, Marquette University, 1957, 42-43.

${ }^{256}$ Ibid., 43-44. 
We have just passed through a reign of terror, surpassed only by the Philadelphia riots. Nearly a hundred poor Irish and Germans have been butchered or burned and some twenty houses have been fired and burnt to the ground. The city authorities, all Know-Nothings, looked calmly on, and they are now endeavoring to lay this blame on the Catholics. ${ }^{257}$

The Philadelphia Riots of 1844, the two St. Louis Election Riots in the 1850s, and the Louisville "Bloody Monday" Riot of 1855 illustrate the political, religious, social, and cultural contexts that Border State Catholic clergy experienced before the Civil War. As the accounts from the 1840 s and 1850 s indicate, Catholics experienced an intense wave of anti-Catholic and nativist sentiment that developed from clashes over the state of public schools, heightened levels of German and Irish immigration to the United States, alcohol consumption and production in urban areas, and partisan politics. Non-Catholic Anglo-Americans feared the influence of immigrants in the United States because they associated life in the Old World with the power and influence of the Catholic Church. During the various nativists riots of the antebellum period, Know-Nothings and other xenophobic groups targeted Catholic and non-Catholic immigrants; however, in doing so, the nativists referred to both groups as espousing "popish," "papal," or "Roman" characteristics. As one historian explained, "Protestant Americans came to regard Catholics — and European immigrants who seemed to share 'Catholic' customs — as unfit for citizenship" and a threat to American values, such as republicanism and an

${ }^{257}$ Martin John Spalding quoted in Ibid., 45-46. According to one historian, Spalding "overestimated the number of victims. Little more than twenty bodies were counted, three-fourths of them foreign-born, the rest natives." For more information, see: Thomas W. Spalding, Martin John Spalding: American Churchman (Washington, DC: The Catholic University of America Press, 1973), 72n65. For more information about the Louisville "Bloody Monday" Riot, see: Agnes Geraldine McGann, Nativism in Kentucky to 1860 (Washington, DC: The Catholic University of America, 1944); Emmet V. Mittlebeeler, "The Aftermath of Louisville's Bloody Monday Election Riot of 1855," Filson History Quarterly 66 (April 1992): 197-219; Ritter, 125-128. 
individual's right of conscience. ${ }^{258}$ Nativist groups targeted Catholic churches, convents and schools, breweries and pubs, and immigrant housing because they all represented the influence of the Roman Catholic Church in the United States. Furthermore, the public schoolhouse proved an arena of contention between Protestants and Catholics because both groups sought to safeguard their respective religious teachings and cultural values. Nativists charged that immigrants who refused to accept a Protestant education undermined the future of America because Old World Catholicism exemplified religious, political, and economic despotism. At the same time, Church leaders in the United States sought to protect the faith of immigrants, arguing that policies which required the use of the King James Bible and the Protestant Ten Commandments in public schools infringed upon the religious liberty of Catholics. Ultimately, most of the disputes between Protestants and Catholics involved partisan politics, as the Democratic Party lobbied for the interests of immigrants. Championing a nativist and anti-Catholic platform, the American or Know Nothing Party emerged during the 1850s to challenge the policies of the Democrats, thereby pitting Protestants against Catholics along partisan lines. ${ }^{259}$

Within this political, religious, social, and cultural landscape, the American Church grew during the prewar period and experienced its own challenges or "crises"as one Catholic historian labeled them- that involved much more than just defending the faith and its followers against nativist and anti-Catholic attacks. ${ }^{260}$ The character and culture of the American Church transitioned during the antebellum period due to the

${ }^{258}$ Ritter, 16.

${ }^{259}$ For more information about the politics of nativism and anti-Catholicism during the antebellum period, see: Tyler Anbinder, Nativism and Slavery: The Northern Know Nothings and the Politics of the 1850s (New York: Oxford University Press, 1992).

${ }^{260}$ Patrick W. Carey, Catholics in America: A History (Westport, CT: Praeger, 2004), 27. 
effects of immigration, administrative decisions made by the American and European hierarchies, and the emergence of new movements within the broader Church. According to Catholic historian Patrick W. Carey, prior to the Civil War, the American Church transitioned in the following three ways: "numerically from one of the smaller American religious communities to the largest single denomination; culturally from an Anglo-American community to a predominantly immigrant community; and religiously from a simple home-centered spirituality to an emotional, highly organized, and ostentatious devotional spirituality that was parish centered." ${ }^{261}$ Due to these changes, American clergy faced issues related to trusteeism, the allocation of resources to serve growing congregations, the blending of various ethnic backgrounds into one cohesive American Catholic unit, and the defense of the Church against nativist and anti-Catholic assaults.

This chapter analyzes the antebellum experiences of Francis Patrick Kenrick, Peter Richard Kenrick, and Martin John Spalding. Furthermore, it illustrates how the political, religious, social, and cultural contexts of the Border States as well as the developments within the American Church shaped the clergy's interpretations of the Civil War. ${ }^{262}$ By exploring the clergy's experiences with nativism, anti-Catholicism, public school debates, trusteeism issues, partisan politics, and their own apologist movement, a clearer picture of the interpretative framework of the clergy emerges. The

261 Ibid.

${ }^{262}$ Although this thesis examines only the backgrounds and experiences of these three prelates, it considers them representative of the experiences of other clergy in their dioceses, states, and region. For example, this thesis contends that the experiences of Martin John Spalding of Louisville reflect what other Kentucky clergy encountered before the Civil War. Thus, it argues that the way in which Spalding's experiences influenced his interpretation of the Civil War occurred among other Border State clergy. 
chapter argues that the backgrounds, experiences, education, and beliefs of Border State clergy during the antebellum period proved critical in shaping how the prelates and priests interpreted the Civil War. This chapter begins with a concise history of the Archdioceses of Baltimore and St. Louis and the Diocese of Louisville, explaining how the Church developed in each bishopric before the war. The subsections will also examine the backgrounds of the archbishop or bishop who served as leader of each respective diocese during the war. In addition to an examination of the Border State sees and their leaders, the chapter analyzes some of the major issues that all three leaders faced during the antebellum period and explains how these factors influenced the interpretative framework of the clergy. Finally, the chapter ends with a section that explains how and why the clergy came to associate the Republican Party with antiCatholicism. Due to the interconnectedness of the antislavery and anti-Catholic movements, Church leaders considered the Republican Party to be the party of northern Protestants, a group that had opposed both slaveholders and Catholics. As the issue over the spread of slavery trumped concerns about immigration and Catholicism in the national political scene, the Know Nothing Party lost support. Former Know-Nothings in the North joined the Republican Party thereby creating the perception among Catholic clergy that the party of Lincoln represented anti-Catholicism. Thus, by the start of the war, the religious leaders in each of the three Border States associated the Republican Party with anti-Catholicism, believed that abolitionists should be held responsible for the sectional crisis, and argued that Catholicism offered a resolution to national issues. The Archdiocese of Baltimore and Francis Patrick Kenrick 
With roots embedded during the colonial period, the See of Baltimore and the origin of Roman Catholicism in the United States date to the seventeenth century, when European Catholics first settled in present-day Maryland. Established in November 1789, the Diocese of Baltimore became the first episcopal see in the United States. In April 1808, Pope Pius VII elevated Baltimore to the rank of a metropolitan see or archdiocese, solidifying its ecclesiastical influence and jurisdiction in the United States, which lasted until the second half of the nineteenth century. ${ }^{263}$ Compared to other dioceses in the Border States, Baltimore felt the impact of immigration on the development of the Church more than Louisville or St. Louis. As Catholic historian Thomas W. Spalding explained, prior to the Civil War, the Archdiocese of Baltimore transitioned from its original "Maryland tradition" to an "immigrant tradition," which came to represent the tradition of most dioceses that developed during the nineteenthcentury. ${ }^{264}$ Established by Baltimore's original prelate, John Carroll, and other AngloCatholics in the state, the Maryland tradition espoused principles of the separation of church and state, religious liberty, and autonomy from the Holy See. Members of the Society of Saint Sulpice, who established St. Mary's Seminary and University in 1791 in Baltimore, played an important role in supporting the Maryland tradition, for the Sulpicians adhered to Gallicanism, a belief system established among French clergy that sought to limit the pope's temporal authority. In essence, the Maryland Catholic tradition meshed well with Enlightenment ideas and the republican form of government adopted

${ }^{263}$ Ibid., 1-25; Thomas W. Spalding, The Premier See: A History of the Archdiocese of Baltimore, 1789-1994 (Baltimore, MD: The John Hopkins University Press, 1995), 17-65.

${ }^{264}$ Spalding, The Premier See, 17. 
by the Founding Fathers. ${ }^{265}$ During his tenure as bishop, Carroll created a "“republican blueprint" for the American Church, which was most recognizable in his support of the trustee system. ${ }^{266}$ The trustee system or trusteeism established lay ownership of churches and other Catholic institutions in the diocese, a practice that Carroll deemed in accordance with American laws and democratic principles. However, contention between trustees and the diocesan leadership as well as a turn toward ultramontane practices weakened the trustee system. In particular, Carroll's successor, Archbishop Leonard Neale, worked to upend trusteeism, which experienced a major setback during the final year of Archbishop James Whitfield's episcopacy. In March 1833, the Maryland Assembly enacted a measure that allowed Church property to be transferred from trustees to clergy. Beginning in 1834 with the tenure of Archbishop Samuel Eccleston, most Church property came under the control of the archbishop. ${ }^{267}$

In addition to the abandonment of the trustee system, the Maryland tradition gave way to the immigrant tradition under the leadership of Eccleston. As Catholic immigrants arrived in Maryland during the first half of the nineteenth century, the state's original Anglo-Catholics resisted the transition of the Church, vowing to maintain the structure established under Archbishop Carroll. However, Eccleston embraced the arrival of new Catholics to Maryland's shore, and in doing so, "preside[d] over the transition of the Catholic Church in the oldest archdiocese from a small, respected, and integrated

${ }^{265}$ Ibid., 21-31, 66-89. For information about the difference in Gallicanism and ultramontanism, see: Carey, 21-22, 53; John T. McGreevy, Catholicism and American Freedom: A History (New York: W. W. Norton, 2003), 12-13, 26-27, 67, 78.

${ }^{266}$ Spalding, The Premier See, 19-20.

${ }^{267}$ Ibid., 19-20, 68-69, 116-117, 141. 
minority into an immigrant church counting a variety of institutions."268 Nevertheless, most of the Catholic immigrants who settled in the Archdiocese of Baltimore were impoverished and unskilled. According to one historian, "immigrant growth brought problems" to Baltimore and other parts of the state because most Marylanders attributed the rise in "violence, pauperism, crime, and disease" to the newly arrived Catholics. ${ }^{269}$

As a result, Church leadership in the Archdiocese of Baltimore encountered two distinct problems during the final decades before the Civil War. One involved the loss of power and influence among the Anglo-Catholics, who relinquished much of the property they once held under the trustee system to the archbishop. The second issue related to the arrival of a large number of immigrant Catholics, which tainted the Protestant perception of the Church. As members of the Baltimore aristocracy, Anglo-Catholics held prominent positions in Maryland politics and society, casting the Church's influence in a positive light. However, the immigrants represented the worst of Catholicism-violence, crime, and poverty—which Protestants in Maryland considered the characteristics that defined the European Church. Non-Catholics could accept and respect the Maryland tradition of Catholicism - republican practices, Gallican principles, and parishioners of Anglo stock—because it seemed more "American" than Old World Catholicism. However, the combination of the abandonment of the trustee system and the ill-effects of heightened immigration led to a rise in nativist and anti-Catholic sentiment in Maryland — an issue that plagued the Catholic leadership in Baltimore before, during, and after the Civil War. ${ }^{270}$

${ }^{268}$ Ibid., 131.
${ }^{269}$ Ibid., 133.
${ }^{270}$ Ibid., 123-153. 
Installed as the sixth archbishop of Baltimore in October 1851, Francis Patrick Kenrick inherited an archdiocese that had transitioned to an immigrant Church. Kenrick dealt with the effects of that transition during the years before the Civil War, experiences which influenced his interpretation of the conflict. Born in Dublin, Ireland in 1797, Kenrick spent the first twenty-four years of his life in Europe, studying for the priesthood in Ireland and Rome. ${ }^{271}$ According to a biographer of Kenrick, the prelate dealt with anti-Catholicism throughout his life, for he was born into an environment of "intensified persecution" of Irish Catholics where Protestants often called for "the downfall of [the] Pope and Popery." ${ }^{272}$ Early in his life, Kenrick established a defensive posture against those who attacked the Church as well as a commitment to the interests of fellow Irish Catholics. These qualities remained with him when he traveled to Rome in 1815 to study at the College of the Propaganda, and in 1821 when Roman authorities transferred him to the Diocese of Bardstown in Kentucky to assist in the growth of the Church in the United States. After Kenrick arrived in Kentucky, Bishop Benedict Joseph Flaget, the leader of the Diocese of Bardstown, directed the Irish priest to serve as chair of the seminary in Bardstown, where he remained for nine years. During his time in Rome, Kenrick obtained the reputation of being a sound scholar, theologian, and Catholic apologist. ${ }^{273}$ One Catholic historian described him as one of the "most important thinkers ... of the

${ }^{271}$ Ibid., 154; John J. O'Shea, The Two Kenricks: Baltimore and St. Louis (Philadelphia, PA: John J. McVey, 1904), 7-21.

${ }^{272}$ O'Shea, 7, 20.

${ }^{273}$ Ibid., 21-41; Spalding, Martin John Spalding, 8-10. 
American Catholic episcopate" and "the Church's foremost American theologian of the nineteenth century.",274

Kenrick made an immediate impact within the Diocese of Bardstown by leading the fight against anti-Catholicism in Kentucky. He authored a series of apologist tracts that defended Catholic doctrine and dogma against charges made by Protestant circuitriding ministers in the state. During 1826 and 1827, Kenrick engaged in a series of theological debates with Protestant leaders, including the president of the Danville Presbyterian College, in which he defended Catholic principles and teachings. ${ }^{275}$ Kenrick's time in Kentucky ended in 1830, when Church authorities transferred him to the Diocese of Philadelphia to resolve issues with the trustee system. On June 6, 1830, Flaget consecrated Kenrick coadjutor bishop of Philadelphia, a diocese in which the relationship between the laity and Church hierarchy suffered the most from trusteeism disputes. At the time of Kenrick's transfer, lay leaders in several Catholic sees-Mobile, Richmond, New Orleans, and Baltimore — resisted the efforts of Church clergy to obtain property titles held by trustees. While other members of the hierarchy failed to seize ownership of property from the laity, Kenrick resolved the issue in Philadelphia, putting an end to trusteeism in the diocese. ${ }^{276}$ "It is Dr. Kenrick," argued one historian, "that the Church in the United States owes its emancipation from the strangulating system of

${ }^{274}$ Leon A. LeBuffe, "Tensions in American Catholicism, 1820-1870: An Intellectual History," PhD dissertation, The Catholic University of America, 1973, 2, 113.

275 O'Shea, 41; Spalding, Martin John Spalding, 8; Clyde F. Crews, An American Holy Land: A History of the Archdiocese of Louisville (Wilmington, DE: Michael Glazier, Inc., 1987), 100; Martin John Spalding, Sketches of the Early Catholic Missions of Kentucky; From Their Commencement in 1787, to the Jubilee of 1826-7 (Louisville, KY: B. J. Webb \& Brother, 1844), 292-293.

${ }^{276}$ O'Shea, 45-49, 68-81. 
trustee dictatorship." ${ }^{277}$ Kenrick's dedication to upending the trustee system-a key feature of Archbishop Carroll's Maryland tradition that supported a democratic American Church—derived from the prelate's ultramontane beliefs and ideas about the proper role of clergy. As an ultramontane, Kenrick "was completely devoted to Rome" and “believed that securing the Church's authority was the overriding goal of Church personnel." ${ }^{278}$ In fact, Kenrick's transfer to the Diocese of Philadelphia represented the shift from a Gallican-based American episcopacy to the emergence of a new group of bishops in the United States who "devoted themselves to standardizing the liturgy according to Roman rites, wrestling property and authority away from lay parish trustees, and fostering such Roman-approved devotions as devotion to the Sacred Heart and the rosary.",279

Following the death of Bishop Henry Conwell on April 22, 1842, Kenrick became the third bishop of the Diocese of Philadelphia. The new prelate vowed to grow the Church in the region and attend to the needs of his parishioners. Kenrick added more priests and oversaw the construction of more churches in the diocese. He also continued to contribute to the Catholic Herald, which Kenrick introduced in 1833 to serve as Philadelphia's diocesan periodical. Articles published in the Catholic Herald elucidated and expounded on Catholic theology, doctrine, and dogma as well as defended the Church against Protestant critics. In the winter of 1842, Kenrick wrote the Controllers of the Public Schools in Philadelphia to contest the required use of the Protestant Bible and Ten Commandments among Catholic students in the city. Kenrick argued that the

${ }^{277}$ Ibid., 74.
${ }^{278}$ LeBuffe, 117.
${ }^{279}$ McGreevy, 26. 
constraint undermined the religious liberty of Catholics and violated the separation of church and state. By challenging the Protestant majority in Philadelphia, Kenrick initiated a religious and political conflict that produced the Philadelphia riots of 1844 . Nativists and anti-Catholic protestors damaged Church property and attacked Irish Catholic citizens in the city. As Kenrick sought to protect the interests of the Church and fellow Irish immigrants, nativist and Protestant leaders demonstrated their concerns about a growing Catholic or papal influence in the country. ${ }^{280}$

In August 1851, Roman officials transferred Kenrick to the See of Baltimore and elevated him to the position of apostolic delegate of the United States thereby granting Kenrick authority over the entire American episcopate. Following the death of Samuel Eccleston, Kenrick became the sixth archbishop of Baltimore, a diocese plagued with many of the same issues as Philadelphia, particularly an intense rivalry between nativists and immigrant Catholics. ${ }^{281}$ Two years after his arrival, Kenrick led a movement in support of Catholic schools in Baltimore. In a May 1853 petition issued to the Baltimore City Council, Kenrick wrote the following:

we maintain that the civil power has no authority either directly from the Creator, or mediately through the people, to interfere with any man in regard to his religious opinions, so long as those opinions do not interfere with the peace and good order of society. The Catholics of Baltimore have at great cost, and without aid from the civic authorities, erected buildings and otherwise provided for the education of their children. We compel no man to contribute to our schools, or to entrust his children to our care; and we ask of the civil authorities that we shall not be compelled to contribute to the support of schools which we do not use and cannot approve. ${ }^{282}$

${ }^{280}$ O'Shea, 120-138.

${ }^{281}$ Ibid., 160-178; Spalding, The Premier See, 153-174.

${ }^{282}$ Petition of Archbishop Francis Patrick Kenrick, May 17, 1853, (copy of the original), filed in box 28-A-1/29-Y-140, Associated Archives at St. Mary's Seminary and University, Baltimore, $\mathrm{MD}$ (hereafter $\mathrm{AAB}$ ). The original petition is located in the Baltimore City Archives, Baltimore, MD. 
Similar to his efforts in Philadelphia, Kenrick defended the interests of the Catholic Church and its institutions against non-Catholic interference. As the contention between Protestants and Catholics continued to intensify over education, Archbishop Gaetano Bendini, a Roman official of Pope Pius IX, arrived in the United States in the summer of 1853. The pope directed Bendini to visit various sees in order to report on the state of the American Church and to oversee diplomatic relations between the United States and the Vatican. Regardless of his true intentions, Bendini's visit symbolized the underlying concern of most Protestants and nativists at the time: Pope Pius IX and the European Church sought to impose its influence and authority over the United States. In the minds of most Protestants, the combined increase in Catholic immigration to the United States, the growth of the American Church during the nineteenth century, and the arrival of Archbishop Bendini meant that Catholicism had become too prominent in the country, and, if not checked, the United States might become a puppet state of the Church. In each city that Bendini visited, Alessandro Gavazzi, a former clergyman turned Catholic critic, delivered harangues against the Church, incited anti-Catholic riots, and, in time, forced the archbishop to suspend his American tour. ${ }^{283}$

Bendini's visit proved the lynchpin for the rise of political nativism and antiCatholicism in the United States. Although both sentiments had been prominent and interconnected culturally throughout the antebellum period, the emergence of the American or Know Nothing Party in 1855 marked an official political movement against

${ }^{283}$ O'Shea, 180-189; Spalding, The Premier See, 172-173; Spalding, Martin John Spalding, 68-69; Carey, 34-35. For a detailed example of how Bendini's arrival led to political anti-Catholicism, see: Andrew Mach, “"The Name of Freeman is Better Than Jesuit': Anti-Catholicism, Republican Ideology, and Cincinnati Political Culture, 18531854," Ohio Valley History 15 (Winter 2015): 3-21. 
both immigrant and native-born Catholics. Prior to the emergence of the Know Nothings, some Anglo-Catholics had joined nativist organizations in Maryland and Washington, D.C. in an effort to resist the transition toward the immigrant Church. ${ }^{284}$ However, the rise of the Know Nothing Party pushed nearly all Catholics-regardless of ethnicity or social class—into the Democratic Party. As one historian explained, "No longer would Catholic Maryland divide between wealthy Whigs [Anglo-Catholics] and working-class Democrats [immigrant Catholics]. A sense of solidarity anchored both in the Democratic Party." ${ }^{285}$ Unfortunately for Catholics, the Know-Nothings gained power in Maryland, obtaining a majority in the state legislature in 1855 as well as the governorship in 1857. Furthermore, Know Nothings maintained control of the city government in Baltimore until 1860. In addition to their political achievements, Know Nothings also succeeded in disseminating nativist and anti-Catholic literature during the final years before the Civil War. ${ }^{286}$ For example, in 1856, Anna Ella Carroll of Maryland published The Great American Battle: Or the Contest Between Christianity and Political Romanism to support the campaign of Millard Fillmore, the Know-Nothing candidate for president that year. Despite being a relative of Archbishop John Carroll, the author converted to Protestantism, deeming its principles and institutions the cornerstone of

${ }^{284}$ For more information about nativism and anti-Catholicism in antebellum Maryland and Washington, DC, see: William W. Warner, At Peace With All Their Neighbors: Catholics and Catholicism in the National Capital, 1787-1860 (Washington, DC: Georgetown University Press, 1994), 192-229. Warner argued that Know-Nothings in the nation's capital differed from their counterparts in other regions of the United States because they did not blend the issues of immigration and religion. According to Warner, the Anglo-Catholics around Washington, DC avoided many of the anti-Catholic demonstrations that plagued their religious brethren in the North and Border States because members of the Church had contributed so much to the city's early success.

${ }^{285}$ Spalding, The Premier See, 174.

${ }^{286}$ Ibid., 173-175. 
"liberty and the free government of the United States." 287 Carroll authored the book to "foster and invigorate" the "Protestant spirit," to encourage:

all who are born in this Protestant land of liberty, and who enjoy, untrammeled by Papal tyranny and priestcraft, the light of science and of Bible truth, to welcome every publication calculated to spread information, dissipate the clouds of mental and moral darkness, and [to] restore the poor, blinded Papists, in bondage to priestcraft, to their native, original right of freedom of conscience-freedom of Bible Republican independence. ${ }^{288}$

Although Carroll differentiated between Catholicism itself and "the system of Popery," taking issue with the latter, The Great American Battle underscored all of the main censures that Protestants offered about the Church and its leaders. ${ }^{289}$

At the height of Know-Nothingism in the United States, Bishop John Timon of Buffalo, New York wrote to Kenrick to suggest that the archbishop release a statement from "the Catholics of Baltimore to their Fellow Citizens throughout the Union.",290 Timon proposed that the "Appeal" detail "in mild but clear terms, the various outrages, insults, and threats, that have injured some, and made others feel that their property and even their lives were in continual danger."291 As archbishop of Baltimore, Kenrick led the American Church through the high watermark of anti-Catholicism and nativism before the Civil War. In Philadelphia and Baltimore, he experienced firsthand riots that destroyed Church property and targeted members of his diocese. Furthermore, Kenrick witnessed the rise of political anti-Catholicism as members of the Know Nothing Party obtained power in Maryland, and the archbishop felt the impact of xenophobic and anti-

${ }^{287}$ Anna Ella Carroll, The Great American Battle: Or the Contest Between

Christianity and Political Romanism (New York: Miller, Orton, \& Mulligan, 1856), vi. 288 Ibid., viii.

289 Ibid., X.

${ }^{290}$ John Timon to Francis Patrick Kenrick, November 17, 1857, 31-S-0, AAB.

${ }^{291}$ Ibid. 
Catholic publications. Kenrick responded to these tribulations by defending the Church, its institutions, its theology, doctrine, and dogma, and its native-born and immigrant followers. Although the Church hierarchy urged American clergy to avoid politics, Kenrick and other prelates recognized the Democratic Party as the pro-Catholic party. As a result, Kenrick and fellow clergy associated the political opponents of the Democratsthe Americans, Know-Nothings, and Republicans - with anti-Catholicism. Thus, aligning with the interests of the Democrats and opposing their political adversaries served as a way for Kenrick and other Border State clergy to defend the American Church and Catholics in their dioceses.

\section{The Diocese of Louisville and Martin John Spalding}

In 1821, when Kenrick arrived in Kentucky, the Diocese of Bardstown entered its thirteenth year. ${ }^{292}$ Having been educated in Rome, Kenrick brought knowledge and prestige to the young diocese. He contributed to the education of new clergy and helped to establish a Catholic intellectual community in Kentucky. Due to the efforts of Kenrick and other Church officials, until 1841, the Diocese of Bardstown served as the epicenter of Catholicism in the antebellum West. From central Kentucky, Catholicism spread throughout the state, beyond the borders of Kentucky, and across nineteenth-century America. As the Church grew during the antebellum period, the clergy in Kentucky faced some of the same challenges as those experienced by their colleagues in Maryland. The trustee system, the changing demographics of the Church, and the lack of resources to minister to and care for the growing congregations created challenges for Kentucky prelates and priests. Furthermore, the rise in nativism and anti-Catholicism fashioned an

292 O'Shea, 38-40; Spalding, Martin John Spalding, 8. Some sources claim that Kenrick arrived in Kentucky in 1823. For more information, see: Crews, 83. 
environment of panic and concern in the Diocese of Louisville. During the years leading up to the Civil War, the clergy in Kentucky developed a temperament that involved both the defense of the Church and a disdain for Protestantism.

In 1808, Bardstown, Kentucky—dubbed the "American Holy Land"-became the first inland Catholic diocese in the United States. ${ }^{293}$ Although most of the diocese's original laity had been born in the United States, the first clergy in Kentucky had been born in Europe. Fathers Stephen Theodore Badin — considered the founder of Kentucky Catholicism—John Baptist David, Guy Ignatius Chabrat, Peter Joseph Lavialle, and Bishop Benedict Joseph Flaget came to Kentucky from France. Arriving in the United States during the late-eighteenth and early-nineteenth centuries, the French clergy as well as Father Charles Nerinckx of Belgium fled the political and religious turmoil caused by the French Revolution. ${ }^{294}$ In fact, one Catholic historian wondered "what Kentucky Catholicism would have been like had there been no French Revolution." ${ }^{295}$ Having experienced the persecution of the Church in Europe, the foreign-born clergy who founded the Diocese of Bardstown sought to suppress any "radical [or] free-thinking attitudes" among their flocks. ${ }^{296}$ However, asserting authority over the laity and maintaining order within the diocese during its earliest years proved difficult because frontier Kentuckians espoused Jeffersonian beliefs. In many ways, the original laity of the Diocese of Bardstown expected the Church to be structured similar to the Maryland

${ }^{293}$ Crews, 23. According to Thomas C. Kelly, former archbishop of Louisville, Bishop Benedict Joseph Flaget first coined the term "Holy Land" to refer to the area around Bardstown, KY.

${ }^{294}$ Ibid., 28-58; Thomas W. Spalding, "The Maryland Catholic Diaspora," U. S. Catholic Historian 8 (Summer 1989): 163-171.

${ }^{295}$ Crews, 58.

296 Ibid., 47. 
tradition, which mirrored Jeffersonian principles that called for a weak central power. However, the clergy sought to establish their authority regarding matters of the Church and feared that liberal ideologies - like those championed by the French revolutionaries and the Jeffersonians - would influence adversely the laity and lead to a breakdown in the Catholic hierarchy. ${ }^{297}$

Similar to the course of events in the Sees of Baltimore and Philadelphia, disputes regarding the trustee system pitted clergy against the laity in Kentucky. For example, in 1807 , members of a congregation in Scott County attempted to sell a portion of land without consulting Badin or Flaget. The Bardstown hierarchy contested the sale, leading to a public debate between Flaget and the laity. Although one of the Scott County trustees claimed that he had obtained permission to sell the land from Bishop Carroll of Baltimore, Flaget obtained title to the property and kept the tract in the diocese. Disputes over the control of Church property also caused problems between members of the hierarchy. In 1812, Badin and Flaget disagreed about who should hold title to a number of landholdings in the diocese. Ultimately, the debate poisoned the relationship between the two clergy, prompting Badin to leave Kentucky. ${ }^{298}$ According to Catholic historian John R. Dichtl, trusteeism issues and infighting among clergy over property titles harmed the perception of the Catholic Church among Protestants. Clergy who seized property from trustees evidenced that even the American Church was a despotic regime, one that sought to consolidate power and property away from the laity and into the hands of the episcopate. However, most prelates believed that they should hold title to the property and viewed those who resisted the policy as potential threats to the stability and structure
297 Ibid., 45-51.
${ }^{298}$ Ibid., 66-67, 79. 
of the American Church. Ultimately, trustee disputes in the United States forced the American hierarchy to increase control over the laity in an effort to prevent disorder. However, the clergy's efforts contrasted with republican principles, thereby contributing to the Protestant perception that Catholicism was incompatible with American political, social, and cultural values. ${ }^{299}$

Although trustee disputes caused problems for the Church, the Diocese of Bardstown experienced tremendous growth during the Early Republic and antebellum periods. Under the leadership of Flaget, who served as the first bishop in Kentucky, the Diocese of Bardstown added new churches, seminaries, and convents. Orders of women religious - such as the Sisters of Loretto at the Foot of the Cross and the Sisters of Charity of Nazareth - as well as the Jesuits, Xaverians, and Trappists opened schools in the state, enrolling both Protestant and Catholics students. Similar to events in Maryland before the Civil War, the Church in Kentucky felt the impact of Irish and German immigration to the United States. Most of the immigrant Catholics settled in either Covington or Louisville, two developing port cities located along the Ohio River. Between 1840 and 1850, Louisville's population doubled, increasing from approximately 21,000 to over 43,000 inhabitants. Of the roughly 43,000, the Irish and Germans accounted for more than one third of the city's total population. In response to the growing Catholic population in the city, in 1841, members of the Church hierarchy transferred the diocesan see in Kentucky from Bardstown to Louisville. ${ }^{300}$

${ }^{299}$ John R. Dichtl, Frontiers of Faith: Bringing Catholicism to the West in the Early Republic (Lexington: The University Press of Kentucky, 2008), 49-86. ${ }^{300}$ Crews, 57-109. 
Flaget remained the bishop for nine years in Louisville, dying in February 1850 after months of medical complications. Having been appointed coadjutor bishop of the Diocese of Louisville in 1848, Martin John Spalding replaced Flaget to become the second bishop of the diocese. Similar to the experiences of Francis Patrick Kenrick, Spalding became diocesan leader at a time when the Church experienced the evolutionary effects of immigration. As the Catholic population in Kentucky increased, Spalding faced new challenges, such as the rise of nativism and anti-Catholicism in his diocese. The prelate's background and education in Rome inspired Spalding to become one of the leading Catholic apologists and defenders of the Church during the antebellum period. Ultimately, the bishop's encounters with anti-Catholicism and his role as an apologist shaped his interpretation of the Civil War. ${ }^{301}$

Born May 23, 1810, in Rolling Fork, Kentucky, Spalding lived near Bardstown for the first twenty years of his life. He attended St. Mary's College and St. Joseph's Seminary near Bardstown, where Spalding developed a close relationship with Francis Patrick Kenrick. According to one historian, Kenrick's efforts as an apologist influenced Spalding throughout his religious career. In 1830, Spalding traveled to Rome to study at the College of the Propaganda, where he excelled as a student of theology and canon law. After being ordained a priest in August 1834, Spalding returned to Bardstown to serve as president of St. Joseph's College. In 1836, Spalding launched The Catholic Advocate, the official publication for the Diocese of Bardstown. True to its title, the periodical published articles that "advocated" the principles of the Catholic Church; thus, Spalding established himself early on as an important religious scholar and Catholic apologist.

${ }^{301}$ Spalding, Martin John Spalding, 46-60. 
Following his resignation as president of St. Joseph's, Spalding served as a circuit-riding priest for eleven parishes near Lexington. However, in 1841 when the see moved to Louisville, Spalding accompanied Flaget to serve as his secretary and vicar general. During the seven-year period before becoming coadjutor bishop, Spalding dedicated his time to scholarly pursuits. In addition to giving lectures at the Louisville cathedral about Catholic theology, doctrine, and dogma, Spalding authored three important books during the 1840s, all of which heralded the Church and attacked Protestantism. ${ }^{302}$

In particular, Spalding's D'Aubigné's "History of the Great Reformation in Germany and Switzerland" Reviewed brought the priest national attention and designated him one of the foremost apologists in the American Church. In the work, Spalding disputed the claim that the Reformation brought liberty and prosperity to Europe. In fact, Spalding charged that the:

Reformation ... had disastrous effects upon doctrine, morals, and worship alike. An endless maze of contradictions and absurdities had been spawned by the "hundred-headed hydra" of Protestantism, and moral decay gripped those countries where salutary Catholic discipline had been cast off ... . Far from promoting civil liberty, the Protestant revolt had produced despotism, debts, standing armies, taxes, and a tighter union of church and state. Far from being an impetus to art and letters, the Reformation had destroyed, deadened, or diverted all literary and artistic impulses. ${ }^{303}$

Some of Spalding's other works focused on the impact of Protestantism in the United

States. According to Spalding, Protestant sects in Kentucky "often came into collision,

${ }^{302}$ Ibid., 1-46, 89-120; Crews, 104-105. Martin John Spalding, D'Aubigné's "History of the Great Reformation in Germany and Switzerland" Reviewed (Baltimore, MD: John Murphy Co., 1844); Martin John Spalding, Sketches of the Early Catholic Missions of Kentucky; From Their Commencement in 1787, to the Jubilee of 1826-7 (Louisville, KY: B. J. Webb \& Brother, 1844); Martin John Spalding, General Evidences of Catholicity: Being the Substance of a Course of Lectures Lately Delivered in the Cathedral of St. Louis, Louisville (Louisville, KY: B. J. Webb and Brother, 1847). ${ }^{303}$ Spalding, Martin John Spalding, 95. 
not only with each other, but with the Catholic church." ${ }^{304}$ Despite the competition and theological differences between the Baptists, Methodists, and Presbyterians, "they united in the principle of hatred of the Catholic religion." ${ }^{305}$ Not only did Spalding take offense to instances of anti-Catholicism in the region, but the priest also outlined what he considered to be the errors and issues related to Protestantism. "Here we see whole masses of population," wrote Spalding, "spread over a vast territory, boasting too of their enlightenment and Bible-learning. $" 306$ Although Protestants may have considered themselves erudite theologians, Spalding contended that they had been "swayed for years by a fanaticism, as absurd as it was blasphemous."307 Spalding wrote that evidence of Protestant fanaticism could be seen during various religious gatherings or camp meetings, like those which swept through the antebellum West during the Second Great Awakening. ${ }^{308}$ In his history of the Church in early Kentucky, Spalding described Protestant camp meetings as comprising "Spasmodic convulsions, which lasted sometimes for hours ... Then there were the 'exercises' of screaming, and shouting, and crying.,

After becoming bishop of Louisville in 1850, Spalding continued to publish proCatholic and anti-Protestant articles and books. In addition to a series of lectures titled "Popular Prejudices against the Catholic Church," in 1855, Spalding published Miscellanea, a 634-page collection of the bishop's lectures and essays on Catholic history

${ }^{304}$ Spalding, Sketches, 82.

305 Ibid.

${ }^{306}$ Ibid., 104.

${ }^{307}$ Ibid.

${ }^{308}$ For more information about the Second Great Awakening, see: Nathan O. Hatch, The Democratization of American Christianity (New Haven, CT: Yale University Press, 1989). ${ }^{309}$ Spalding, Sketches, 105. 
and theology. During the same year as the publication of Miscellanea, Spalding witnessed the ascent of the Know Nothing Party in Kentucky. In August 1855, the citizens of Louisville elected a Know-Nothing mayor-John Barbee — and George Prentice, editor of the Louisville Journal, endorsed the nativist party. Anti-Catholic riots erupted in Louisville on August 6, 1855, when Know-Nothings took control of the city's election polls, burned immigrant houses, and threatened to destroy the Catholic cathedral. ${ }^{310}$ Similar to the effects of Know-Nothingism in Baltimore, the "Bloody Monday" Riot united all Kentucky Catholics—whether native or foreign-born —within the Democratic Party. According to one biography of the bishop, Spalding had been politically a "Whig by conviction until 1855"; however, the "rise of the Know-Nothings completed his conversion to the Democratic Party."311 Following 1855, most Catholic clergy considered the election of Democratic candidates important for the protection of the American Church. Even Spalding, who believed that clergy should remain uninvolved in politics, took an interest in the success of the Democratic Party. For example, in October 1856, Spalding received a letter that assured the bishop of Democratic candidate James Buchanan's victory in the upcoming presidential election. "We are all throwing up our hats over the result in Pa \& Ind," wrote B. G. Caulfield, "Fremont is a dead cock in the pit \& old Buck is our next President." on November 1, 1858, Caulfield informed Spalding that "Tomorrow will be a most

${ }^{310}$ Spalding, Martin John Spalding, 70-73, 104-110; McGann, 48-113; Martin John Spalding, Miscellanea: Comprising Reviews, Lectures, and Essays, on Historical, Theological, and Miscellaneous Subjects (Louisville, KY: Webb, Gill, \& Levering, 1855).

311 Spalding, Martin John Spalding, 121.

312 B. G. Caulfield to Martin John Spalding, October 28, 1856, Box 5, Folder 7, Archdiocese of Louisville Records (hereafter CDBL), University of Notre Dame Archives, Notre Dame, IN (hereafter UNDA). 
exciting day in this state [Illinois]. ${ }^{, 313}$ In the senate race that pitted Republican Abraham Lincoln against Democrat Stephen A. Douglas, Caulfield had "every expectation of [a] Douglas Election." 314

During the same year of Douglas's victory, Spalding sparred with George Prentice of the Louisville Journal in a series of editorials about the proper use of public school funds in the city. Spalding argued that the city government should construct schools for Catholic children, so that the religious liberty of all Louisvillians would be protected. However, Prentice did not support the use of public funds for separate institutions, arguing instead that Catholic and Protestant students should attend the same schools. ${ }^{315}$ During the final year before the Civil War, Spalding embarked on a speaking tour that included visits to New York City and the nation's capital, where the prelate lectured about the influential role of the Catholic Church in the history of western civilization. The day after Abraham Lincoln's famous Cooper Union Address, Spalding spoke at the Institute, offering an assessment of the European Church and life in the Old World before the Reformation. The following month, the bishop visited the Smithsonian Institution and lectured about the role played by the Catholic Church in the protection of civil liberties. ${ }^{316}$ According to Spalding, the Church ended serfdom in Europe and the Crusades safeguarded Christians from "the barbarism [and] the despotism" of the "Turkish and Mohammedan" peoples. ${ }^{317}$ After returning to Louisville, Spalding

${ }^{313}$ B. G. Caulfield to Martin John Spalding, November 8, 1858, Box 5, Folder 8, CDBL, UNDA.

${ }^{314}$ Ibid.

${ }^{315}$ Spalding, Martin John Spalding, 110-111; McGann, 152-158.

${ }^{316}$ Spalding, Martin John Spalding, 117-118.

317 "Smithsonian Lecture," National Intelligencer, March 10, 1860, Box 10, Folder 55, CDBL, UNDA. 
celebrated the publication of his two-volume history of the Reformation. Similar to his previous work, Spalding's latest contribution reflected the bishop's usual promotion of Catholicism and polemics against Protestantism. Comprising nearly 1,000 pages, the The History of the Protestant Reformation constituted a "tour de force unequalled in range by any other American Catholic writer of the nineteenth century." 318 Thus, similar to the position of Francis Patrick Kenrick in 1860, Spalding emerged from the antebellum period with a well-established apologist pedigree, one that focused on defending the Catholic Church as well as deriding Protestantism. Spalding also joined Kenrick and other Border State Catholics in support of the Democratic Party, for the clergy considered the Democrats the party most dedicated to the interests of the Church and its followers. The Archdiocese of St. Louis and Peter Richard Kenrick

Established in July 1826, the Diocese of St. Louis incorporated a large region of land west of the Mississippi River. After Roman officials divided the Diocese of Louisiana into two episcopal sees, creating dioceses in St. Louis and New Orleans, the states of Arkansas, Missouri, and Iowa came under the dominion of the St. Louis leadership. The diocese also incorporated Indian Territory and the western half of Illinois, until Church officials founded the Diocese of Chicago in 1843. As one Catholic historian explained, Manifest Destiny led to the formation of the Diocese of St. Louis. Although the diocese's original clergy focused on ministering to Native Americans in the region, the influx of German and Irish immigrants to Missouri during the 1840s and 1850s changed the composition and structure of the bishopric. Similar to the effects of

${ }^{318}$ Spalding, Martin John Spalding, 113-114; Martin John Spalding, The History of the Protestant Reformation, in Germany and Switzerland: and in England, Ireland, Scotland, the Netherlands, France, and Northern Europe (Louisville, KY: Webb and Levering, 1860). 
immigration in Baltimore and Louisville, St. Louis—elevated to an archdiocese in 1847 — had become a diocese with a large immigrant-Catholic population by the start of the Civil War. Having experienced episodes of anti-Catholicism and nativism-much like their coreligionists throughout the Border South — the clergy in St. Louis entered the war years with a focus on defending the Church and challenging Protestantism. ${ }^{319}$

Born in Italy, Joseph Rosati served as the first bishop of the Diocese of St. Louis. Rosati's tenure lasted until 1843, when the bishop died unexpectedly while visiting Rome. From 1827 until his death, Rosati worked to increase the size of the Church in the diocese. In particular, St. Louis experienced tremendous growth as German and Irish Catholics relocated to the city during the late-1830s and 1840s. Because Missouri had been controlled by French and Spanish Catholics before it became part of the United States, most considered St. Louis a sanctuary for Catholics. In fact, many Catholics who settled along the New England coast relocated to Missouri during Rosati's tenure to escape the anti-Catholic sentiment espoused by many northern Protestants. As the Catholic population grew around St. Louis, Rosati worked to obtain more priests and construct new schools and churches in the diocese. Although the Catholic population in St. Louis had risen to approximately 8,000 residents by 1840 , the city boasted only one church - the Cathedral of St. Louis. In order to obtain money to build new Catholic institutions in the diocese, Rosati planned a trip to Europe in 1840. However, before leaving, the bishop blessed the cornerstone for the second church in the city. By 1860 ,

${ }^{319}$ Spalding, The Premier See, 152. For a general history of the Archdiocese of St. Louis, see: John Rothensteiner, History of the Archdiocese of St. Louis: In Its Various Stages of Development from A.D. 1673 to A.D. 1928, 2 volumes, (St. Louis, MO: Blackwell Wielandly Co., 1928). 
the number of parishes in St. Louis had increased to sixteen, fourteen of which were erected following Rosati's death. ${ }^{320}$

Although the Church grew under the leadership of Rosati, Peter Richard Kenrick witnessed a more dramatic increase in the Catholic population of Missouri, particularly the concentration of German and Irish Catholics who settled in St. Louis. Furthermore, a number of religious orders entered the diocese and built new institutions in St. Louis and throughout Missouri. Despite the tremendous growth in Catholic population before the Civil War, the boundaries of the diocese became smaller as the Church created new bishoprics during the 1840 s and 1850 s. $^{321}$ As a result, by 1860, Kenrick and other clergy within the Archdiocese of St. Louis focused on the interests of the large immigrantCatholic population which had settled within or near the diocesan see. Similar to his brother and his colleague in Louisville, Kenrick's background and experiences as a clergyman during the antebellum period shaped his interpretations of the Civil War. Although Catholics may have been welcomed in St. Louis during the earliest decades of the nineteenth century, Kenrick and other Missouri clergy witnessed an increase in nativism and anti-Catholicism before the war. In ways similar to other Border State clergy, by 1860, Kenrick had become a devoted Catholic apologist, a guardian of immigrant Catholics, and an antagonist of Protestantism.

Before becoming the Catholic leader of St. Louis, Kenrick spent his childhood and some of the earliest years of his adulthood in Europe. Kenrick was born on August

${ }^{320}$ John Gilmary Shea, History of the Catholic Church in the United States from the Fifth Provincial Council of Baltimore, 1843, to the Second Plenary Council of Baltimore, 1866 (Rahway, NJ: The Mershon Company Press, 1892), 213-214; William Barnaby Faherty, The St. Louis German Catholics (St. Louis, MO: Reedy Press of the University of Nebraska Press, 2004), 2-7, 23; Ritter, 43-45.

${ }^{321}$ Shea, 213-224; Faherty, The St. Louis German Catholics, 9-30. 
17, 1806, in Dublin, Ireland, where he received a Catholic education along with his brother. An intense era of contention between Catholics and Protestants defined the Kenricks' youth. Despite experiencing anti-Catholicism in Ireland, Kenrick's faith persevered, and in 1827, he enrolled at St. Patrick's College and Seminary to study for the priesthood. After being ordained in 1832, Kenrick served for a year as chaplain of the Carmelite Convent in Dublin. The following year, the priest traveled to the United States to assist his brother in the Diocese of Philadelphia. Following seven years of pastoral work, Kenrick contemplated joining the Society of Jesus to pursue a more scholarly and less religious role in the Church. In 1840, he traveled to Rome to enter the Jesuit order; however, once he arrived in Italy, Kenrick decided to return to the United States. During Kenrick's journey back to Philadelphia, Bishop Rosati met with Bishop Francis Patrick Kenrick to discuss the prospect of a coadjutor being appointed to the See of St. Louis. The Bishop of Philadelphia recommended his brother and Rosati supported the decision. Thus, on November 30, 1841, Rosati consecrated Peter Richard Kenrick coadjutor bishop of St. Louis with the right of succession to the Missouri see. ${ }^{322}$

Following the death of Rosati in September 1843, Kenrick inherited a diocese of approximately 100,000 Catholics and sixty-five churches stretched across a region that incorporated several states and territories. During the years before the Civil War, Kenrick created several new sees within the American West thereby reducing the geographic size of his diocese. In October 1847, many of the new dioceses became suffragan sees of St. Louis because Church officials elevated Kenrick's bishopric to the rank of metropolitan archdiocese. As archbishop of St. Louis, Kenrick assisted in the

${ }^{322}$ O'Shea, 267-283; Carey, 200-201. 
growth of the Church in the region. He oversaw the construction of new churches, convents, and orphanages, welcomed new priests and religious orders into the diocese, and encouraged the dissemination of Catholic teachings by opening new schools and seminaries in his see. ${ }^{323}$ Under Kenrick's leadership, St. Louis gained the reputation of being the "Rome of the West." 324

Although Catholic institutions developed throughout his diocese, Kenrick did not encounter the same trusteeism disputes that plagued other American clergy. Unlike his brother and Bishop Spalding, Kenrick adhered to Gallican principles, which as one historian explained, meant the archbishop "emphasized the significance and quasiautonomy of the national church. In the United States he favored those policies that demonstrated the American character of the Catholic Church. ${ }^{325}$ In fact, Kenrick scoffed at the idea of accumulating the title to all Church properties in his diocese, arguing that doing so would make "his occupation "more secular than episcopal.",326 Despite the influence of Gallicanism, Kenrick proved an ardent defender of the Church during the antebellum period. Similar to Spalding, Kenrick utilized the press to spread his pro-Catholic and anti-Protestant sentiments. In fact, Spalding contributed several apologist articles_-including a diatribe against Puritanism titled "Mr Webster's Bunker Hill Speech"- to the Catholic Cabinet, the diocesan periodical Kenrick launched after becoming archbishop. ${ }^{327}$ In addition to criticizing Protestantism within the pages of the Catholic Cabinet, Kenrick also published a few scholarly works on the history of

${ }^{323}$ O'Shea, 283-288; Carey, 201; Shea, 213-224.

${ }^{324}$ Ritter, 45.

${ }^{325}$ Carey, 201.

${ }^{326}$ Ibid., 29.

${ }^{327}$ O’Shea, 283; Spalding, Martin John Spalding, 92-93. 
religion. For example, in 1848, Kenrick released the second edition of a work that challenged the validity of religious ordinations in the Church of England. The archbishop argued that the controversy over the ordinations would continue unless the "church be reunited with the See of Rome." ${ }^{328}$ Kenrick also criticized the Anglicans for allowing the "civil power" to fracture a holy union, and anticipated that "dissent among her own children" would lead to the collapse of the Church of England. ${ }^{329}$

Ultimately, apologist literature forged a bond between members of the American hierarchy in the Border South. However, while Spalding and the Kenricks defended the Church in newspapers, books, and public lectures, nativist and anti-Catholic groups gained followers in Maryland, Kentucky, and Missouri. As in the dioceses of Baltimore and Louisville, the dramatic increase in the number of Catholic immigrants and the growth of the Church proved the primary concerns of native-born Protestants in Missouri. As St. Louis became more Catholic and European, many evangelical Protestants living east of the Mississippi viewed the Gateway City as a "dark land" inhabited by "heathens and infidels." ${ }^{, 330}$ While members of the St. Louis hierarchy responded to these charges with pro-Catholic works, many northern evangelicals countered with their own publications, which encouraged Protestants to relocate to Missouri in order to save the American West from Catholics and immigrants. The evangelical calls for "[r]eligious and nativist crusades," argued one historian, provided motivation for Protestants along

${ }^{328}$ Peter Richard Kenrick, The Validity of Anglican Ordinations and Anglican Claims to Apostolical Succession Examined, second edition, (Philadelphia, PA: Eugene Cummiskey, 1848), 18.

329 Ibid.

${ }^{330}$ Jeffery S. Adler, Yankee Merchants and the Making of the Urban West: The Rise and Fall of Antebellum St. Louis (New York: Cambridge University Press, 1991), 50. 
the eastern shore to relocate to St. Louis. ${ }^{331}$ Although not all Protestants who migrated to Missouri did so to rid the state of Catholics, many joined nativist or anti-Catholic groups, such as the Know-Nothings, and participated in public demonstrations against the Church. In addition to the presence of native-born Protestant critics of the Church, many Freethinking and Protestant Germans also resided in St. Louis. Non-Catholic Germans joined Anglo-Protestants in denouncing the Church as an un-American and despotic organization. As editor of Anzeiger des Westens - one of antebellum Missouri's most circulated periodicals_-German Freethinker Heinrich Börnstein contributed weekly articles that attacked the Church and its leaders. In 1852, Börnstein published The Mysteries of St. Louis, a popular anti-Catholic novel that portrayed the city's clergy as immoral tyrants. Thus, in many ways, clergy in the Archdiocese of St. Louis responded to an anti-Catholic movement that involved both native and foreign-born critics of the Church. $^{332}$

In 1852, the Catholics of St. Louis experienced the first of two major nativist uprisings. Two years later, the St. Louis Know-Nothing Riot occurred, causing damage to a number of immigrant-Catholic homes and businesses. Due to the Know-Nothing campaign against Catholicism, members of the Church in the Archdiocese of St. Louis rallied behind the Democratic Party during the final decade before the Civil War. Unlike

${ }^{331}$ Ibid., 54.

332 McGreevy, 22-23; Ritter, 110-111. According to Ritter, the nativists of St. Louis did not differentiate between non-Catholic and Catholic Germans, thereby ostracizing a number of potential allies in their movement against the Catholic Church. The St. Louis nativists considered both Protestant and Catholic immigrants as being "Catholicized." As a result, at times, foreign-born Protestants, Catholics, and Freethinkers joined forces - despite deep religious prejudices - to counter nativist attacks. For more information about the complexity and nuance of religious and ethnic politics in antebellum St. Louis, see: Ritter, 107-123. 
the Catholics of Baltimore and Louisville, who experienced an anti-Catholic movement led by a primarily native-born Protestant coalition, united under the Know-Nothing banner, St. Louis Catholics also encountered the anti-Catholic sentiments of Protestant and Freethinking Germans. Although some German-Americans supported the Democratic Party prior to, during, and after the Civil war, many non-Catholic Germans left the Democrats and joined the Republican Party or other free-soil groups. As historian Luke J. Ritter explained:

German Protestant activists held several anti-Kansas Bill meetings in the summer of 1854, where they, in a manner akin to their Know Nothing counterparts, denounced the "intrigues of papal agents" in the Democratic Party ... German Freethinkers did not share the Protestant religious worldview that bolstered nativist anti-Catholicism and anti-foreignism, but they did have in common the goal of limiting the influence of the Roman clergy. Freethinking organs ... spouted anti-Catholic vitriol which reinforced the nativist idea that European Catholicism was incompatible with American republicanism. ${ }^{333}$

As a result of the defection of non-Catholic Germans to the Republican Party, clergy in the Archdiocese of St. Louis and other Border State sees viewed the Democratic Party as the pro-Catholic faction. Thus, to Kenrick and other prelates and priests, defending the Church against nativism and anti-Catholicism meant opposing the Know-Nothings and Republicans - the political enemies of the Democrats.

Anti-Republicanism, Anti-Abolitionism, and Anti-Protestantism

On November 1, 1860, the Wide-Awake Pictorial published a cartoon titled "The Boat that Rides in Safety," which portrayed a capsized boat marked with a Know-

${ }^{333}$ Ritter, 137. According to an article by historian Kristen L. Anderson, eighty percent of St. Louis Germans voted for Abraham Lincoln in the 1860 presidential election, thereby illustrating the overwhelming support for the Republican Party among non-Catholic Germans in the city. For more information, see: Kristen L. Anderson, "German Americans, African Americans, and the Republican Party in St. Louis, 18651872," Journal of American Ethnical History 28 (Fall 2008): 34-51. 
Nothing banner. Although a boat carrying Democrats sailed ahead of the KnowNothings, a Republican vessel floated alongside the nativists, allowing the KnowNothings to enter at the rear of their anti-slavery rig. "“Take you in! well, yes," declared the Republican skipper, “'if you don't kick up a row in the boat—-take a seat in the stern and be quiet. Not otherwise." ${ }^{\prime 334}$ The cartoon symbolized the political fate of most northern Know-Nothings after 1857, once the issue over the spread of slavery led to the downfall of their movement. In the cartoon, the Republican captain welcomed KnowNothings into his party; however, he made it clear that concerns about immigrants or Catholics would not be tolerated, for those issues might disrupt the Republicans' antislavery course. Although the cartoon gave the impression that the Know-Nothing agenda - nativism and anti-Catholicism—would not be part of the Republican platform, most American Catholics interpreted the flight of Know-Nothings into the party of Lincoln as simply a continuation of nativism and anti-Catholicism under a new political banner. ${ }^{335}$

That anti-Catholicism continued within the Republican Party seemed obvious to most members of the American Catholic hierarchy. Throughout the antebellum period,

${ }^{334}$ Max Longley, For the Union and the Catholic Church: Four Converts in the Civil War (Jefferson, NC: McFarland \& Company, 2015), 138.

${ }^{335}$ Ibid. Despite what Catholics may have assumed or believed about Republicans, historian Eric Foner argued that nativism and anti-Catholicism played a minor role in uniting members of the party. Instead, the northern free labor ideology and a shared animus toward the southern Slave Power proved the more important catalysts in leading to a Republican victory in 1860 . For more information about the role of nativism and anti-Catholicism in the formation of the Republican Party, see: Eric Foner, Free Soil, Free Labor, Free Men: The Ideology of the Republican Party before the Civil War, second edition (New York: Oxford University Press, 1995), 226-260. For more information about the Republican Party platform of 1860, see: Thomas C. Mackey, editor, A Documentary History of the American Civil War Era, volume 2, Political Arguments (Knoxville: The University of Tennessee Press, 2013), 71-74. 
the most ardent anti-Catholics had also advocated an end to slavery. Northern Protestant preachers and publications often referred to slavery and Catholicism as the twin despotisms of American society. The interconnectedness of the antislavery and antiCatholic movements among native-born Protestants in the North suggested to Catholic clergy that where one of the two sentiments prevailed the other likely followed. Thus, in the minds of many prelates and priests, the Republican anti-slavery platform meant that the party also harbored anti-Catholic sentiments. As Catholics witnessed many former Know-Nothings join the Republicans, members of the American hierarchy began to perceive of the party of Lincoln as an anti-Catholic party. In fact, some clergy believed that once the Republicans brought an end to slavery they would then endeavor to eradicate American Catholicism. ${ }^{336}$

Not only did Church officials perceive the Republicans to be anti-Catholic and associate them with the nativist riots that occurred during the prewar period, but prelates and priests also argued that the party of Lincoln represented the ill-effects of Protestantism in American society. Clergy considered the Republican antislavery platform and the party's association with abolitionism to be examples of Protestant fanaticism. Although by 1860 nearly all Protestant sects contained an antislavery faction, almost all members of the Church — in both the United States and Europe — denounced abolitionism as a radical movement that opposed Catholic teachings. Catholic leaders considered abolitionism to be a product of Protestant liberalism which threatened to upend the social and legal status quo in the country. As abolitionists demanded an

${ }^{336}$ For more information about the interconnectedness of the antislavery and antiCatholic movements during the antebellum period, see: W. Jason Wallace, Catholics, Slaveholders, and the Dilemma of American Evangelicalism, 1835-1860 (Notre Dame, IN: University of Notre Dame Press, 2010). 
immediate end to slavery, despite American laws that protected the institution, Catholic leaders sought to preserve order by upholding the sanctity of the Constitution. Thus, prelates and priests believed that the Republican Party — the party of northern Protestants — endangered the stability of the country by advancing its antislavery platform. In particular, ultramontane clergy—like Francis Patrick Kenrick and Spalding — adhered to the belief that slavery remained a legitimate human relation that fit within a structured social hierarchy. Clergy referenced Catholic theology, doctrine, and dogma to offer an alternative course of action than the one pursued by abolitionists and antislavery Republicans. According to members of the American hierarchy, Catholicism defended national laws, protected the social order, and prevented political factionalism because it provided a central authority - the Church - to settle internal disputes. On the other hand, prelates and priests contended that Protestantism allowed for lawlessness, fomented social disorder, and led to political disunion because, without the acceptance of a central moral authority, Protestantism allowed each man (or woman) to become a law unto himself (or herself). Thus, not only did clergy oppose the Republican Party because of its perceived anti-Catholic stance, but prelates and priests also disparaged the party of Lincoln because it represented the interests of northern Protestants, a group that Catholics considered uninformed religious fanatics that fomented disunion. ${ }^{337}$

${ }^{337}$ Gjerde, 221-256; McGreevy, 43-67; Wallace, 113-145; William B. Kurtz, "“This Most Unholy and Destructive War': Catholic Intellectuals and the Limits of Catholic Patriotism," in So Conceived and So Dedicated: Intellectual Life in the CivilWar Era North, edited by Lorien Foote and Kanisorn Wongsrichanalai (New York: Fordham University Press, 2015), 217-223. 
By 1860, the Kenricks and Spalding had witnessed dramatic change within their dioceses. The rise of immigration and growth of the Church spawned an anti-Catholic movement that spread across the Border South. While facing the challenges wrought by groups like the Know-Nothings, the Kenricks and Spalding also dealt with trusteeism disputes and suffered from a lack of resources necessary to provide for their growing immigrant flocks. As members of the American hierarchy, the Kenricks and Spalding understood their primary responsibility to be the preservation of the Church and its ministry in the United States. To combat the anti-Catholic movement, Border State clergy supported an apologist movement that incorporated articles in diocesan journals, private publications, and public lectures. The apologist movement cast the legacy of the Church in a positive light and defended the Church's teachings against anti-Catholic critics. Furthermore, the Catholic apologists attacked Protestantism, suggesting that its various sects preached fanaticism and subscribed to erroneous theology. The clergy also grew to appreciate the Democratic Party as a defender of the Church and its followers because the Democrats opposed the Know-Nothings. By 1860, the Republicans proved the Democrats' primary political adversary; therefore, Catholic clergy also derided Lincoln's supporters. Although the Republicans may have endorsed only an antislavery platform, Catholics considered the party to be anti-Catholic and an example of how Protestantism had poisoned American politics. As a result, Border State clergy not only opposed the Republicans but argued that the party's rise to power-which the Catholics attributed to the mixing of evangelical religion and antislavery politics-illustrated how Protestantism threatened the order and stability of the country. According to the clergy, to avoid disorder and disunion, the United States needed to adhere to Catholicism. 
Ultimately, the background, experiences, education, and beliefs of the Kenricks,

Spalding, and other Border State clergy during the antebellum period set the stage for a religious interpretation of the Civil War, one that championed Catholicism and bemoaned abolitionism and Protestantism. 


\section{CHAPTER III}

“THE WHOLE WORLD SEEMS TO BE GETTING OUT OF JOINT”: THE CATHOLIC RESPONSE TO THE ELECTION OF 1860, THE SECESSION MOVEMENT, AND THE START OF THE CIVIL WAR IN THE BORDER SOUTH ${ }^{338}$

On November 12, 1860, Bishop Martin John Spalding of Louisville informed his metropolitan, Archbishop John Baptist Purcell of Cincinnati, that the South had "assum[ed] a very menacing attitude" and that disunion appeared "imminent.",339 Six days before Spalding penned the letter to Purcell, Abraham Lincoln earned a majority of the electoral votes in the 1860 presidential election. As northerners celebrated the Republican victory and southern Fire-Eaters advocated secession, Catholic clergy in the Border States feared the outbreak of war in their dioceses and dreaded the effects of disunion on the American Church. Not only did prelates and priests foresee a dismal future for the nation, they also attributed the fractured state of the Union to the ill-effects of Protestantism in American society. Clergy perceived the election of Lincoln as a triumph for northern evangelicalism, the secession movement as a product of Protestant fanaticism in the South, and the war as a consequence of religious fragmentation in the United States. Furthermore, the secession movement and the outbreak of the Civil War thrust upon the American Church a series of dilemmas that disrupted the Catholic ministry. Many members of the American hierarchy urged the clergy to remove

${ }^{338}$ Martin John Spalding to John Baptist Purcell, November 12, 1860, II-5-a, Archdiocese of Cincinnati Collection (hereafter CACI), University of Notre Dame Archives, Notre Dame, IN (hereafter UNDA).

339 Ibid. 
themselves from the political scene, arguing that the intermixing of religion and politics had given rise to the Know-Nothing movement, abolitionism, and secession. However, some prelates and priests felt compelled to support the political movements within their respective regions - either secessionism or unionism - in order to avoid having their loyalty questioned by the Protestant majority. Endorsing the policy of neutrality, Border State clerics proved some of the loudest voices for an apolitical hierarchy, one that would promote reunion and peace and work to avoid a schism within the American Church. In his November 1860 letter to Purcell, Spalding anticipated the challenges that he and other Border State clergy would face as well as alluded to the disorder caused by the infusion of religion-evangelical Protestantism - into national politics. As the bishop of Louisville explained: "The Lord deliver us! The whole world seems to be getting out of joint." 340

This chapter examines how prelates and priests in the Border States interpreted and responded to the presidential election of 1860 , the secession crisis, and the start of the Civil War in the Border South. Divided into subsections, this chapter illustrates how the apologist movement and Catholic principles or teachings shaped the ways in which Border State clergy interpreted each event. Furthermore, this chapter examines how the politics of secession and civil war created challenges for the clergy, particularly regarding the administration of the American Church. The first subsection covers the election of 1860 and explains why the majority of prelates and priests supported northern Democratic candidate Stephen Douglas. Although they derided the Republican Party and abolitionism, the clergy did not support secession. The second subsection explores the

${ }^{340}$ Ibid. 
clergy's responses to the secession movement and underscores why prelates and priests associated disunion with Protestant fanaticism. This subsection also identifies how Civil War-era politics proved problematic for the unity and public perception of the American Church, as some clergy adopted a partisan position thereby disrupting the Church's apolitical posture. The third subsection explains why Border State clergy espoused the policy of neutrality. As states in the South seceded and the nation prepared for war during the first months of 1861, prelates and priests sought to remain apolitical and neutral while urging peace and a restoration of order in the nation. However, once the war began in their dioceses, the clergy focused on continuing the ministry of the Church, providing chaplains and nurses for soldiers on both sides of the war, and surviving the conflict in their region. After experiencing firsthand the tragedies of war in their dioceses, some clergy became even more critical of Protestantism and turned to their faith for comfort and guidance.

\section{The Catholic Response to the Election of 1860}

Although the clergy in Maryland, Kentucky, and Missouri did not publicly endorse or campaign for a candidate in the presidential election of 1860 , the majority of prelates and priests privately supported Stephen Douglas, the northern Democratic candidate from Illinois. The clergy's antebellum experiences with nativism and antiCatholicism forged a strong bond between members of the Church and Democrats. However, by the summer of 1860, the Democratic Party had divided into northern and southern wings, forcing Border State Catholics to decide between Douglas and John C. Breckinridge of the southern Democratic Party. Although some Catholics backed Breckinridge - particularly fellow Kentuckians from the western portion of the statemost members of the Church in the region supported Douglas. The northern Democratic 
candidate promoted unionism and vowed to uphold the status quo, which, to Catholic clergy, meant an adherence to the law and the preservation of social order. ${ }^{341}$ As Catholic historian William B. Kurtz explained, “Catholics' faith and religious worldview, which emphasized stability over reform, also made them predisposed to favor a conservative and national party."342 Douglas gained the support of Catholics because he advocated the policy of popular sovereignty to decide the fate of slavery in the West, opposed abolitionism, promised to protect the rights of immigrants, and promoted the sanctity of the Union by running a national campaign. ${ }^{343}$ For example, regarding the dispute over slavery in the western territories, the Douglas Democratic platform pledged to "abide by the decision of the Supreme Court of the United States [the Dred Scott decision] upon these questions of Constitutional law."344 Thus, clergy from the Border States viewed Douglas as the candidate least influenced by Protestant liberalism and most committed to the interests of the Church and the nation.

Although Catholics demonstrated their commitment to the Democratic Party in 1860, few prelates or priests supported Breckinridge because they believed that his campaign encouraged secession. For example, in August 1860, Spalding "“thank[ed]

${ }^{341}$ James M. McPherson, Battle Cry of Freedom: The Civil War Era (New York: Oxford University Press, 1988), 213-216; Thomas W. Spalding, Martin John Spalding: American Churchman (Washington, DC: The Catholic University of America Press, 1973), 130-131; Richard Carwardine, Lincoln: A Life of Purpose and Power (New York: Alfred A. Knopf, 2006), 58-60; William B. Kurtz, Excommunicated from the Union: How the Civil War Created a Separate Catholic America (New York: Fordham University Press, 2016), 29-31.

${ }^{342}$ Kurtz, Excommunicated from the Union, 29.

${ }^{343}$ Ibid., 30; John T. McGreevy, Catholicism and American Freedom: A History (New York: W.W. Norton \& Company, 2003), 71.

${ }^{344}$ Thomas C. Mackey, editor, A Documentary History of the American Civil War Era, volume 2, Political Arguments (Knoxville: The University of Tennessee Press, 2013), 66. For more information about the significance of the Dred Scott decision, see: McPherson, 170-188. 
God"" that "Breckenridge [sic] \& his faction have been cleaned out in Ky.",345 The bishop from Louisville considered the southern Democrat to have been "'of bad stock, \& in wretched disunion company.",346 In addition to the belief that Breckinridge supporters sought to break up the country, Catholics also disparaged the southern Democrats because they utilized anti-Catholic politics to court Protestant voters. During the summer of 1860, the southern Democratic campaign included attacks against Archbishop John Hughes of New York and Pope Pius IX. Furthermore, the southern Democratic Party portrayed Douglas as a drunken pawn of the pope, thereby exaggerating his ties to the Church. Although his wife, Adele Douglas, joined the Church, Douglas never accepted the faith. Nevertheless, Republicans, Constitutional Unionists, and southern Democrats utilized his family's membership in the Church to cast Douglas a Catholic candidate. In fact, one historian suggested that Douglas's association with Catholicism inhibited a merger between the northern Democrats and Constitutional Unionists in New York and other states in the region. As a result, the Republican Party benefited from anti-Catholic politics and the perception that Douglas belonged to the Church. ${ }^{347}$ In large part,

${ }^{345}$ Martin John Spalding quoted in Spalding, Martin John Spalding, 130. Although Spalding loathed Breckinridge, the southern Democratic candidate finished second behind John Bell of the Constitutional Union Party in the presidential race in Kentucky. For more information about the election of 1860 in Kentucky and the Border South, see: John A. Boyd, "Neutrality and Peace: Kentucky and the Secession Crisis of 1861," PhD dissertation, University of Kentucky, 1999; William C. Harris, Lincoln and the Border States: Preserving the Union (Lawrence: University of Kansas Press, 2011), 11-41; Christopher Phillips, The Civil War in the Border South (Santa Barbara, California: Praeger, 2013), 2-15; Luke E. Harlow, Religion, Race, and the Making of Confederate Kentucky, 1830-1880 (New York: Cambridge University Press, 2014), 108133.

${ }^{346}$ Martin John Spalding quoted in Spalding, Martin John Spalding, 130.

${ }^{347}$ George C. Rable, God's Almost Chosen Peoples: A Religious History of the American Civil War (Chapel Hill: The University of North Carolina Press, 2010), 34; Douglas R. Egerton, Year of Meteors: Stephen Douglas, Abraham Lincoln, and the 
Constitutional Unionists avoided an association with Douglas because many of its members had been former Know-Nothings. Once the Know Nothing Party began to decline in 1857, old Whigs and other opponents of the Democratic Party sought to form a new political organization. By 1860, former Whigs, Know-Nothings, Oppositionists, and disillusioned Democrats united to form the Constitutional Union Party. ${ }^{348}$ Although its official platform addressed only the party's "duty to recognize no political principle other than THE CONSTITUTION OF THE COUNTRY, THE UNION OF THE STATES, AND THE ENFORCEMENT OF THE LAWS," the Constitutional Unionists' association with nativism and anti-Catholicism alienated the support of most Border State Catholics. ${ }^{349}$

Although they expressed animus toward the southern Democrats and Constitutional Unionists, nearly all Catholic religious and lay leaders denounced the Republican Party, its platform, and, most of all, its leaders. Despite the fact that the 1860 Republican platform centered on preventing the spread of slavery into the West and mentioned nothing about restricting the rights or liberties of immigrants or Catholics, prelates and priest throughout the United States loathed the Republican Party. Ironically, the thirteenth resolution of the Republican platform safeguarded the interests of Catholics, both foreign and native-born. Party members "opposed ... any change" to naturalization laws and pledged the "full and efficient protection to the rights of all

Election that Brought on the Civil War, second edition (New York: Bloomsbury Press, 2013), 4-7; Carwardine, 88-90, 124-125.

${ }^{348}$ McPherson, 221-222; Egerton, 89-101; Christopher M. Paine, “"Kentucky Will Be the Last to Give Up the Union': Kentucky Politics, 1844-1861," PhD dissertation, University of Kentucky, 1998, 200-270.

${ }^{349}$ Mackey, A Documentary History of the American Civil War Era, volume 2, 69-70. 
classes of citizens, whether native or naturalized, both at home and abroad." ${ }^{, 350}$ Yet, the party's association with Know-Nothingism, nativism, anti-Catholicism, evangelical Protestantism, and abolitionism proved too significant for Catholics to support the party of Lincoln. As Bishop John Timon of Buffalo explained: “"There seems to be an antiCatholic twang in much of what they [Republicans] write and say. A moderate antiCatholic party with a concealed warfare would do us much more harm than the brutal force and open warfare of the KN [Know-Nothings].,",351

In large part, the anti-Catholic sentiment that clergy associated with the Republicans derived from the party's relationship with evangelical Protestantism. Historian Richard Carwardine argued that by 1858 Lincoln and his supporters had "deliberately fused appeals to Protestant millennialism and Enlightenment rationalism" to transform the Republicans into a "crusading party.",352 Although he lost the 1858 senate race to Douglas, Lincoln's message resonated with northern evangelicals, who overwhelmingly backed Lincoln during his presidential campaign. Ultimately, the support of northern evangelicals led to a Republican victory in the November 1860 election. According to Carwardine, Lincoln's campaign embodied the fears, beliefs, and values of northern evangelicals because it combined antislavery, anti-Catholic, millennialist, and moral sentiments into a single message manifested as a political crusade for Protestant Christianity. ${ }^{353}$ In response, Catholics recoiled at the obvious evangelical influence in the Republican Party. Not only did they fear that a Republican victory might lead to a reinvigorated anti-Catholic movement, but clerics also associated

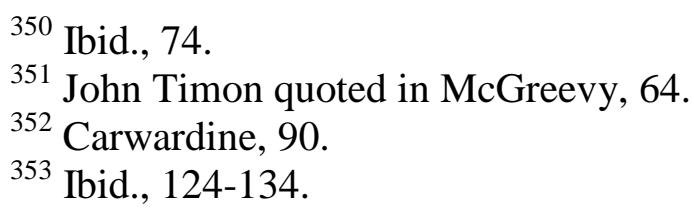


evangelical Protestantism with a radical liberalism that they thought threatened the structure and stability of American society. For example, Spalding referred to Ohio Republicans William Dennison and Salmon P. Chase as "fanatical firebrands," who incited regional animosity and instigated civil war. ${ }^{354}$ Catholics shared this belief with Protestant Democrats, who also "derided the Republicans as 'a religious Sect' . . the natural allies of 'blue light purtians' and 'fanatical Sabbatarians,' who were working to unite church and state, and universalize New England morality." ${ }^{355}$ During the war, Garrett Davis, a Democratic congressman from Kentucky, argued that the "self-righteous Protestants of the Northeast" or "Puritans" had caused the war rather than members of the southern "Slave Power." 356 Despite the clergy's common attacks against Protestantism, Catholics shared an alliance with some non-Catholic Democrats because both groups opposed the evangelical or "Puritan" element of the Republican Party. Although nativism and anti-Catholicism existed within the Republican Party, Lincoln did not espouse those sentiments. Carwardine argued that Lincoln "benefitted from an anti-Catholic animus" within the party, yet the Illinoisan "had done nothing to inflame" it and "almost certainly disapproved" of its "political exploitation." ${ }^{357}$ In fact, throughout most of his political career, Lincoln derided those who attacked immigrants or Catholics. Although his wife, Mary Todd Lincoln, complained about the "wwild Irish"” and thought that "foreigners" should be kept "within bounds," Lincoln scoffed at the

\footnotetext{
${ }^{354}$ Martin John Spalding to John Baptist Purcell, April 11, 1861, II-5-a, CACI, UNDA.

${ }_{355}^{355}$ Carwardine, 128.

${ }^{356}$ Michael Vorenberg, Final Freedom: The Civil War, the Abolition of Slavery, and the Thirteenth Amendment (New York: Cambridge University Press, 2001), 95. ${ }^{357}$ Carwardine, 125.
} 
Know-Nothing movement. ${ }^{358}$ As he explained in the summer of 1855 to Joshua F. Speed of Kentucky:

I am not a Know-Nothing. That is certain. How could I be? How can any one who abhors the oppression of negroes, be in favor of degrading classes of white people? ... As a nation, we began by declaring that "all men are created equal." We now practically read it "all men are created equal, except negroes." When the Know-Nothings get control, it will read "all men are created equal, except negroes, and foreigners, and catholics." When it comes to this I should prefer emigrating to some country where they make no pretence [sic] of loving libertyto Russia, for instance. ${ }^{359}$

Furthermore, as a Whig politician in Illinois, Lincoln denounced the 1844 anti-Catholic riots in Philadelphia and pushed for his party to adopt a resolution for religious freedom. ${ }^{360}$ The only documented account of Lincoln questioning the place of immigrants in the United States or expressing disgust about foreigners occurred during his 1858 senatorial campaign. In a letter penned before Election Day, Lincoln wrote that he expected to defeat Douglas as long as "wwe are not over-run with fraudulent [Irish] votes to a greater extent than usual."”361 Lincoln confided to his law partner, William Herndon, about his fears of an "Irish constituency" or "“floating Hibernian' population" who sold "their votes to the Democrats." ${ }^{362}$ Despite losing the election to Douglas, Lincoln did not adopt a nativist or anti-Catholic political posture; instead, he continued to focus his political energies on preventing the spread of slavery into the West.

${ }^{358}$ Mary Todd Lincoln to Emilie Todd Helm, November 23, 1856 in Mary Todd Lincoln: Her Life and Letters, edited by Justin G. Turner and Linda Levitt Turner (New York: Alfred A. Knopf, Inc., 1972), 46.

${ }^{359}$ Abraham Lincoln to Joshua F. Speed, August 24, 1855, in Lincoln: Selected Speeches and Writings, edited by Don E. Fehrenbacher (New York: Vintage Books/The Library of America, 1992), 105-106.

${ }^{360}$ John H. Silverman, Lincoln and the Immigrant (Carbondale: Southern Illinois University Press, 2015), 24-25.

${ }^{361}$ Abraham Lincoln quoted in Ibid., 42.

${ }^{362}$ Abraham Lincoln quoted in Ibid., 43. 
Nonetheless, as a leader in the Republican Party, Lincoln developed the reputation among some Catholics of being a nativist and an anti-Catholic. For example, Lincoln received a letter during the 1860 presidential campaign "asking if he was 'against the people who profess the Roman Catholic Church."”363 Another concerned voter noted that the Irish and Germans of New York believed that the Republican Party “"opposed ... giving patronage to foreigners." ${ }^{\prime 364}$ Thus, despite Lincoln's record of denouncing antiCatholicism, nativism, and the Know Nothing Party, his association with the Republicans meant that most Catholics considered Lincoln to be a radical evangelical who advocated an antislavery platform that not only went against Church teachings but threatened the nation.

The Catholic Response to Disunion and the Effects of Secession on the Church

In a December 28, 1860 letter to Francis Patrick Kenrick, William George McCloskey, the rector of the American College at Rome, alluded to the political situation in the Papal States. At the time of McCloskey's letter, the Vatican faced combined attacks led by Italian revolutionaries, such as Giuseppe Garibaldi, and the Kingdom of Piedmont. Garibaldi and the Piedmontese sought to overthrow the temporal authority of the pope and to unify Italy under a democratic government. Although French Emperor Louis Napoleon III supported Italian unification, the Catholic monarch backed the interests of the pope and the Church. ${ }^{365}$ "We really know nothing about the real intention

363 Ibid., 94-95.

364 Ibid., 95.

365 David J. Alvarez, "The Papacy in the Diplomacy of the American Civil War," Catholic Historical Review 69 (April 1983): 233-234; Mark A. Noll, The Civil War as a Theological Crisis (Chapel Hill: The University of North Carolina Press, 2006), 129-132; Robert Emmett Curran, Shaping American Catholicism: Maryland and New York, 18051915 (Washington, DC: Catholic University of America Press, 2012), 103-104; Max 
of those who direct the Politics of Italy," wrote McCloskey, "Emperor Napoleon \& Cavour \& the rest of that worthy body directs things in their own way." ${ }^{\prime 366}$ Despite "the difficulties of [their] position," McCloskey noted that "the Holy Father remains unmoved $\&$ goes on with the duties of his station as if the world around him was perfectly calm."367 As members of the European hierarchy experienced political revolution and civil war in the Papal States, Kenrick and other Border State clergy witnessed states throughout the South exit the Union. By December 28, 1860, the state legislature of South Carolina had officially passed an ordinance of secession. Within a month, five more states in the Deep South would secede as well as Texas and the Upper South states by the summer of 1861 . In addition, the citizens of Maryland, Kentucky, and Missouri contemplated whether or not to remain in the Union or to join the newly formed Confederate States of America. ${ }^{368}$ Undoubtedly, the resiliency of Pope Pius IX served as an example to Kenrick and other Border State clergy as they dealt with their own domestic insurrection. As the pope strove to continue the ministry of the Church in Europe, prelates and priests in the Border South worked to maintain the unity of the American Church and the country. Similarly, as Pius IX blamed the Italian rebellion on radical anti-Catholic liberalism, clerics in the United States blamed the secession crisis on Protestant fanaticism. As Catholic historian Mark A. Noll explained, Church officials drew a parallel between the events in Europe and the secession crisis in the United States. Believing that they were "charged by God

Longley, For the Union and the Catholic Church: Four Converts in the Civil War (Jefferson, NC: McFarland Publishing, 2015), 133-136.

${ }^{366}$ William George McCloskey to Francis Patrick Kenrick, December 28, 1860, 30-P-8, Associated Archives at St. Mary's Seminary and University, Baltimore, MD (hereafter AAB).

${ }^{367}$ Ibid.

${ }^{368}$ McPherson, 234-241, 276-284. 
to uphold stability in social as well as ecclesiastical domains," members of the European and American hierarchies denounced both Italian unification and secession because they believed that both derived from radical liberalism. ${ }^{369}$ Thus, Border States clergy—many of whom subscribed to ultramontane beliefs and remained devoted to the popeinterpreted secession as an action that opposed Catholic teachings.

On December 1, 1860, the Louisville Guardian —-Spalding's official diocesan newspaper - chided the actions of " "the Rev. N. Perche for setting up this right [of secession] on theological principles." ${ }^{370}$ During the winter of 1860-1861, NapoléonJoseph Perché served as editor of the Le Propagateur Catholique, the official Catholic periodical of the Archdiocese of New Orleans. Less than a month following the election of 1860, Perché published articles that endorsed secession as a legitimate response to Lincoln's victory. The French Catholic defended disunion by utilizing Church teachings and principles. ${ }^{371}$ Although Perché announced a pro-Confederate stance, Spalding took an immediate position against secession, proclaiming in a January 1861 sermon that he hoped "'to see the glorious stars and stripes" continue to "wave over our undivided country." "’372 In St. Louis, Archbishop Peter Richard Kenrick adopted a similar position. On January 12, 1861, Kenrick issued a "letter to the Roman Catholics of [the] city," urging them to "avoid occasions of public excitement, to obey the laws, to respect the

${ }^{369}$ Noll, The Civil War as a Theological Crisis, 130. According to Noll, "since the European revolutions of 1848 Italian liberals had striven to deprive the papacy of its temporal domain, and among the world's most enthusiastic cheerleaders for the Italian antipapal forces were American Protestants, the loudest of whom were the United States' best-known liberals, the party of abolitionism."

${ }^{370}$ Louisville Guardian, December 1, 1860 quoted in Judith Conrad Wimmer, "American Catholic Interpretations of the Civil War," PhD dissertation, Drew University, 1979, $131 \mathrm{n} 126$.

${ }^{371}$ Ibid., 130-131.

${ }^{372}$ Marin John Spalding quoted in Ibid., 100. 
rights of all citizens and to keep away from public gatherings where words of passions might endanger tranquility. ${ }^{, 373}$ Two weeks earlier, Kenrick had written a similar circular to the clergy of St. Louis. Kenrick advised his prelates and priests to add additional

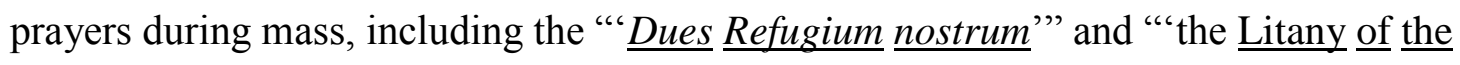
Saints," "“in order to implore the Divine Mercy in the present critical situation of Public Affairs." "374 Furthermore, Kenrick encouraged clergy to invite members of “"'respective Congregations to attend these services and unite their prayers with those of the Church"' in an effort to avoid "“all causes of unnecessary excitement [disunion]." "375 As the archbishop of St. Louis worked to discourage secession in Missouri, his brother exchanged letters with Bishop John Timon of Buffalo that condemned the actions of some southern clergy. In January 1861, Timon urged Francis Patrick Kenrick to send "a kind word ... to the Administrator at $\mathrm{N}[\mathrm{ew}] \mathrm{O}[\mathrm{rleans}]$," in regards to the "strong secession views" espoused by the "Propagateur Catholique." 376 While Timon believed that the "violence of this epedemick [secession]" would fade, the prelate noted that "it is the glory of our Church that we keep aloof from politics."

Although some clergy in the South accepted secession, even utilizing Church teachings to defend the action, Spalding and the Kenricks held steadfast to unionism and spoke out against domestic insurrection. Catholic historian Michael Pasquier argued that many southern clergy, such as Perché of Louisiana and William Henry Elder of Mississippi, supported or refused to denounce secession because they identified

${ }^{373}$ Wimmer, 100.

${ }^{374}$ Peter Richard Kenrick quoted in Mary Emmanuel White, “Archbishop Peter Richard Kenrick and the Civil War,” MA thesis, Saint Louis University, 1948, 58.

375 Peter Richard Kenrick quoted in Ibid., 58-59.

${ }^{376}$ John Timon to Francis Patrick Kenrick, January 17, 1861, 31-T-47, AAB. 377 Ibid. 
themselves as both religious leaders "bent upon the Catholic evangelization of a nonCatholic nation and pastoral protectors of a southern way of life based on slavery." 378 Although Pasquier's work focused exclusively on French Catholic missionaries in the region, his arguments also help explain the experiences of some native-born clergy who also felt the pressure to defend both their Church and their region. Knowing that his colleagues in the Border States had denounced secession, William Henry Elder, bishop of the Diocese of Natchez, wrote Francis Patrick Kenrick to explain the position that he and other prelates and priests in the South faced after their states exited the Union. "While I deeply regret the destruction of the Union," wrote Elder, "I am far from finding fault with the movement." ${ }^{, 379}$ Elder informed Kenrick that neither he nor his clergy had "recommend[ed] secession"; however, the clergy did "explain to those who might inquire, that ... their religion did not forbid them to advocate it." ${ }^{380}$ According to Edler, southern Catholics "were bound to do, what they believed the safety of the community required."381 Whether immigrant or native-born, members of the Church needed to "support [the] State Govt \& the new Confederacy ... to enrol [sic] as soldiers - to go forward with their taxes - [and] to cooperate in any way they had occasion for."382 Similar to his colleagues in the North and Border States, Elder's message advocated the maintenance of law, order, and social stability. Once Mississippi seceded, the bishop accepted the decision made by the majority of his fellow southerners, and in doing so,

${ }^{378}$ Michael Pasquier, Fathers on the Frontier: French Missionaries and the Roman Catholic Priesthood in the United States (New York: Oxford University Press, 2010), 170.

${ }^{379}$ William Henry Elder to Francis Patrick Kenrick, no date, 29-D-12, AAB. 380 Ibid. 381 Ibid. 382 Ibid. 
Elder supported both his region and adhered to the principles of his faith. Although Elder and his clergy may have informed their flocks that secession did not run contrary to Catholic teachings, the prelates and priests did not require the laity to support disunion. In his letter to Kenrick, Elder stated that those who supported secession did so "as good citizens" and not as a result of the "Church . . . having decided either for or against the propriety of secession." 383 Furthermore, Elder declined an invitation "to give the Prayer \& Benediction" at a public celebration because he believed in keeping separate the political and religious spheres. ${ }^{384}$

Although Elder and his colleagues in the Border States expressed different opinions about secession, both agreed that disunion resulted from Protestant fanaticism. Catholics from seceded states blamed secession on the fanaticism of northern abolitionists who violated the Constitution and forced the South out of the Union. For example, Elder stated that southerners had "proceeded calmly \& dispassionately," while northerners demonstrated "haste \& passion" and "excitement."385 Similarly, Bishop Patrick Lynch of South Carolina blamed secession on the zeal of " "black republicans.",386 However, Border State Catholics condemned both northern and southern Protestants for disunion. Spalding spoke out against the "wretched disunion company" of the southern Democrats, the "fanatical firebrands" in the Republican Party, and the radical Protestant preachers in both regions. ${ }^{387}$ Throughout the late-1850s and in 1860, the Louisville

383 Ibid.

384 Ibid.

385 Ibid.

${ }^{386}$ Patrick Lynch quoted in Kurtz, Excommunicated from the Union, 38.

${ }^{387}$ Martin John Spalding quoted in Spalding, Martin John Spalding, 130; Martin John Spalding to John Baptist Purcell, April 11, 1861; April 21, 1861, II-5-a, CACI, UNDA. 
Guardian, Spalding's official newsletter, published articles that "spoke out against the 'fanatical preachers"' of the country. ${ }^{388}$ Border State clergy viewed the secession crisis as a consequence of the infusion of fanatical or radical religion - in their opinion Protestantism - in both the North and the South. Assuming a unique position within the border region, the Kenricks, Spalding, and other clergy in Maryland, Kentucky, and Missouri criticized politicians and religious leaders on both sides of the secession crisis. In doing so, the clergy offered an alternative or third voice during the secession period, one that suggested Catholic teachings would have prevented the crisis.

Border State clergy argued that an adherence to Church teachings would have prevented disunion because Catholics offered a resolution to the dispute over slavery. For example, in December 1860, Spalding's diocesan organ asserted the following:

We will not believe that the men of the North are ready to rush upon the evils of civil war on account of a mere idea that their consistency is involved in the question of equal rights between the black and the white races on this continent. We will not believe that they are ready to sacrifice their own liberties through their efforts to give liberty to the slaves of the South. ${ }^{389}$

A month after the publication of the Louisville Guardian editorial, Augustin Verot of Florida delivered a sermon at a Catholic parish in St. Augustine. Offering it as a "guide [to] the country in crisis," Verot divided his sermon into two parts. ${ }^{390}$ The first part railed against northern abolitionists, who Verot believed had caused the secession crisis, and the second part outlined the rights of slaves. A printed version of the sermon appeared in several Catholic periodicals, and Verot sent a personal copy to Francis Patrick Kenrick in

\footnotetext{
${ }^{388}$ Wimmer, 108.

${ }^{389}$ Louisville Guardian, December 1, 1860 quoted in Ibid., 108n59.

${ }^{390}$ Longley, 145.
} 
Baltimore. ${ }^{391}$ In a letter to the archbishop, Verot noted that his sermon "proved the legitimacy of Slavery against abolitionists . . render[ing] it lawful.."392 "The occasion seemed to be favourable," stated Verot, "for asserting now that Slavery is not a moral evil incompatible with practical religion. ${ }^{393}$ Although Verot defended slavery as a lawful and moral institution, the Florida cleric also wrote that "masters must promote morality among slaves, $\&$ have the marriage laws observed by them $\&$ not separate families, treat them proudly \& give them an opportunity of knowing religious truth." ${ }^{\text {394 }}$ Ultimately, Verot's sermon resonated with clergy in the Border States because the vicar apostolic of Florida articulated well the Church's position toward slavery, and in doing so, he explained why secession and civil war could have been avoided. During the secession period and start of the war, essentially all American Catholic clergy accepted slavery as a lawful and legitimate human relation, which had "'received the sanction of God, of the Church, and of society at all times, and in all governments. ${ }^{., 395}$ In short, the law protected slavery, Catholic teachings recognized human bondage, and the Church expected slaveholders to ensure the wellbeing of their slaves. Therefore, Border State clergy argued that if the majority of Americans adhered to the Catholic position about slavery then secession and civil war should and could be avoided. Border State clergy deemed wrong both northern opponents of slavery and southern supporters of disunion because both groups appeared to be influenced by Protestant fanaticism. Abolitionists

${ }^{391}$ Ibid., 145-146; Rable, 41-42; Augustin Verot, A Tract for the Times: Slavery \& Abolitionism, Being the Substance of a Sermon, Preached in the Church of St. Augustine, Florida, on the $4^{\text {th }}$ Day of January, 1861 (New Orleans, LA: Catholic Propagator Office, 1861).

392 Augustin Verot to Francis Patrick Kenrick, January 18, 1861, 32-D-6, AAB. 393 Ibid.

${ }^{394}$ Ibid.

${ }^{395}$ Augustin Verot quoted in Longley, 145. 
and secessionists violated the law, threated the social order, led the country to civil war, and, most importantly, dismissed the principles of Catholicism. As Catholics in the North fell in line to support the Union and Catholics in the South supported secession, Border State clergy underscored the faults in both movements, prayed for peace and a restoration of order, focused on their role as religious leaders in the American Church, and held fast to Catholic teachings, which advocated reason and an adherence to law. As Peter Richard Kenrick directed the Catholics of the Archdiocese of St. Louis in 1861:

Beloved Brethren, in the present distressed state of the public mind, we feel it our duty to recommend you to avoid all occasions of public excitement, and to obey the laws, to respect the rights of all citizens, and to keep away, as much as possible, from all assemblages where the indiscretion of a word or the impetuosity of a momentary passion might endanger public tranquility. Obey the injunction of the Apostle, St. Peter: "Follow peace with all men, and holiness, without which no man can see God."396

Although Border State clergy advocated peace and unity, the politics of secession affected the administration of the American Church. In particular, southern clergy who supported the Confederacy openly undermined the neutral or apolitical posture of the Church. Many clergy, especially those in the Border States, argued that prelates and priests should remove themselves from speaking about politics and avoid declaring an allegiance during the war. For example, Francis Patrick Kenrick noted that he was "averse to the practice" of raising flags above churches and praying for a specific cause. ${ }^{397}$ Similarly, Spalding ensured that one of his July 1861 sermons "breath[ed]"

${ }^{396}$ Peter Richard Kenrick quoted in White, 66.

${ }^{397}$ Francis Patrick Kenrick to Martin John Spalding, May 4, 1861, 34-K-51, AAB. In the same letter, Kenrick noted that "necessity might determine" him to abandon his apolitical stance. In fact, four months after penning the letter to Spalding, Kenrick prayed for the Union in a sermon at the Baltimore cathedral. His decision alienated some of the pro-Confederate sympathizers in his archdiocese. For more information, see: 
only "peace and brotherly love, without committing himself to any political party." 398 As a Border State prelate, Spalding worried about preserving the unity of the American Church. As he explained in May 1861, "There is a terrible feeling among the Caths of the extreme South against those Caths of the North who are preparing to fight against them." ${ }^{399}$ In addition to secession pitting Catholics against one another on the battlefield, disunion also disrupted the appointment of prelates to various open sees in the United States. The Church filled vacant episcopates through a process that began by drafting a list of potential candidates. After secession began, the nomination of clergy who supported the Confederacy created a dilemma within the American hierarchy. During the summer of 1860, leadership positions in the Dioceses of Pittsburgh and Savannah as well as the Archdiocese of New Orleans remained unfilled. After some "hesitating" and contemplation, Michael Domenec agreed to become the bishop of Pittsburgh in December 1860; however, the two dioceses in the South went unfilled until the summer of 1861.400

Longley, 143-144; Spalding, The Premier See, 175-176; John Tracy Ellis, American Catholicism, second edition (Chicago: The University of Chicago Press, 1969), 96-97. 398 Journal of Martin John Spalding, Bishop of Louisville, April 8, 1860-March 27, 1864 (transcript), Box 10, Folder 9, Archdiocese of Louisville Records (hereafter CDBL), UNDA, July 29, 1861, p. 19. Peter E. Hogan transcribed the journal in April 1950 and provided a copy to the University of Notre Dame Archives. The original diocesan journal is located in the Department of Archives and Manuscripts, Mullen Memorial Library, Catholic University of America, Washington, DC The transcript will be cited hereafter as (Spalding Journal, CDBL, UNDA).

${ }^{399}$ Martin John Spalding to John Baptist Purcell, May 18, 1861, II-5-a, CACI, UNDA.

${ }^{400}$ Francis Patrick Kenrick to Peter Richard Kenrick, July 13, 1860; August 17, 1860; November 13, 1860; December 11, 1860 in The Kenrick-Frenaye Correspondence: Letters Chiefly of Francis Patrick Kenrick and Marc Antony Frenaye, edited by F. E. T. (Philadelphia, PA: Wickersham Printing Company, 1920), 445-453. 
As the archbishop of Baltimore - the premier see in the United States_Franics Patrick Kenrick played an important role in nominating new prelates. Unfortunately for Kenrick, the nomination process for the sees in Savannah and New Orleans corresponded with the secession crisis. In a letter to the archbishop of St. Louis, Kenrick noted that he believed Napoléon-Joseph Perché of New Orleans "to be unfit to occupy a see" because he advocated secession. ${ }^{401}$ Furthermore, the pro-Confederate sympathies of Father Anthony Dominic Pellicer of Alabama caused similar problems for the American Church. Two weeks after the election of 1860, Kenrick noted that he "supported Pellicer" for the vacancy in Savannah, despite his "inferior" qualifications. ${ }^{402}$ However, four months later, Bishop Joshua [Josue] E. Young of Erie, Pennsylvania-one of Kenrick's suffragan bishops - wrote that Pellicer had "notably identified himself with the Southern Revolution." ${ }^{403}$ In the time between Kenrick's endorsement of Pellicer and Young's assertion that Pellicer supported the Confederacy, Alabama and six other states in the Deep South seceded from the Union. Like other southern clergy, Pellicer deemed it necessary to support the newly formed Confederate States of America. However, to Young, a bishop in the North, Pellicer's actions constituted "a most criminal \& treasonable outrage." ${ }^{404}$ As a result, Young informed his metropolitan that he could not support Kenrick's decision to nominate Pellicer for the See of Savannah. Instead, Young believed that "the recommendation ... should come from the Bishops of the new

${ }^{401}$ Francis Patrick Kenrick to Peter Richard Kenrick, February 28, 1861 in Ibid., 455-458.

${ }^{402}$ Francis Patrick Kenrick to Martin John Spalding, November 19, 1860, 34-K38, AAB.

${ }^{403}$ Joshua [Josue] E. Young to Francis Patrick Kenrick, March 18, 1861, 32-O-18, AAB. 404 Ibid. 
Republic [the Confederacy] or at least from those whose consciences can permit them" to accept secession. ${ }^{405}$ Also disparaging the breakup of the Union, Kenrick agreed with Young that the priest's pro-Confederate sympathies proved problematic. As Kenrick explained in July 1861, Pellicer demonstrated "piety," a "blameless moral character," and "human kindness," yet he had "recite[d] prayers for the Assembly for the Confederates. ${ }^{, 406}$ Rather than branding Pellicer a traitor, like Young had done, Kenrick noted that the southern bishop "could hardly avoid" not backing the Confederacy in a seceded state. ${ }^{407}$ Although Kenrick could empathize with southern clergy—like Pellicer, Perché, and William Henry Elder — who supported the government in their region, the archbishop of Baltimore did not support their appointments to any of the open sees. Ultimately, the politics of secession and the start of the Civil War created a rift within the American hierarchy as members from the North, the South, and the Border States deliberated the appointment of new prelates. As a Border State clergyman, Kenrick navigated the middle ground between southern clergy who accepted secession as a reality and northern clergy who deemed it treasonous. In the end, Kenrick's animus toward secession led him to relinquish his support for the openly pro-Confederate clerics. ${ }^{408}$

${ }^{405}$ Ibid.

${ }^{406}$ Francis Patrick Kenrick to Peter Richard Kenrick, July 15, 1861, in The Kenrick-Frenaye Correspondence, 459.

${ }^{407}$ Ibid.

${ }^{408}$ The See of New Orleans remained open until the summer of 1861, when JeanMarie Odin was transferred from the Diocese of Galveston, Texas to Louisiana. For more information about Odin's transfer, see: Jean-Marie Odin to Francis Patrick Kenrick, April 22, 1861, 30-V-5; June 25, 1861, 30-V-6, AAB; Francis Patrick Kenrick to the Bishop of Newark, April 10, 1861, 32-A-U8, AAB. The Church filled the See of Savannah in July 1861 by elevating Augustin Verot to bishop of Savannah with ecclesiastical powers over Florida. For more information about Verot's elevation, see: Michael Gannon, Rebel Bishop: Augustin Verot, Florida's Civil War Prelate (Gainesville: University Press of Florida, 1964). 
In addition to producing problems with the appointment of new prelates, the secession crisis also led to other administrative calamities for the Church in the Border South. On New Year's Eve 1860, H. A. Livers wrote Father Michael Bouchet, a priest in the Diocese of Louisville, to inform him that "nothing has been done as yet relating to your salery [sic]."409 Bouchet had served as a visiting priest at Livers's parish and had written the lay Catholic to request payment for his services. Unfortunately for Bouchet, Livers noted that the uncertainty over secession had stymied business in Kentucky. The "whole country is panic striken [sic]," wrote Livers, for there was "scearstey [scarcely] a dollar in surkelation [sic]." ${ }^{410}$ Livers hoped that after "a change [took] place" the parish would be able to pay Bouchet. ${ }^{411}$ During the same month, Father Thomas Joyce of St. Patrick's Church in Louisville decided "to set up [his] watch at raffle in order to raise money" for the Irish Catholic parish. ${ }^{412}$ Similar to Livers, Joyce mentioned the scarcity of currency, which the priest "ow[ed] to the financial and political crisis" in the region. ${ }^{413}$ Joyce valued the "double cased gold hunting" watch at "175 dollars," and anticipated that several "one dollar" raffle tickets would be purchased. ${ }^{414}$ Despite the priest's efforts, by late January 1861, "times ha[d] become a good deal worse" in Louisville. ${ }^{415}$ Joyce reported that approximately "six thousand persons" had lost employment due to the "general deranged state of trade and commerce."416 According to the clergyman,

${ }^{409}$ H. A. Livers to Michael Bouchet, December 31, 1860, (transcript)Box 4, Folder 25, CDBL, UNDA.

410 Ibid.

411 Ibid.

412 Thomas Joyce to ?, December 6, 1860, Box 5, Folder 15, CDBL, UNDA.

${ }^{413}$ Ibid.

414 Ibid.

415 Thomas Joyce to ?, January 21, 1861, Box 5, Folder 15, CDBL, UNDA. ${ }^{416}$ Ibid. 
Louisville did not alone experience the negative effects of disunion. "I know not of any city where prospects appear to brighten," wrote Joyce. ${ }^{417}$ The priest met "persons coming here form various places who sadly realize the fact of Louisville being as unfortunately circumstanced as the places where they left." ${ }^{418}$ For Bouchet, Joyce, and other clergy in the Border South, the secession crisis created a financial burden on the ministry of the Church. Unemployment and stymied commerce meant that parishioners lacked the funds to tithe regularly. As a result, clergy struggled to allocate the money necessary to maintain their parishes, schools, orphanages, and other Catholic institutions in the region. Already considering secession an avoidable and unwarranted consequence of the infusion of fanatical religion into the political process, the clergy's financial struggles during the period certainly intensified their aversion to Protestantism and served as evidence for commending Catholicism. Despite their struggles during the secession crisis, Border State clergy remained committed to continuing the ministry of the Church and promoting peace in the country. As Francis Patrick Kenrick confided to Spalding in late-November 1860: "I am endeavoring to attend to my duties as a bishop."

\section{Border State Clergy Endorse Neutrality}

By 1861 , most prelates and priests in the Border States believed that their duties involved only the religious sphere. "I marvel that a priest, with no official, representative standing," argued the archbishop of Baltimore, "should presume to set forth in the newspapers his own opinion ... on the most grave and difficult questions [of allegiance

\footnotetext{
417 Ibid.

418 Ibid.

${ }^{419}$ Francis Patrick Kenrick to Martin John Spalding, November 19, 1860, 34-K48, AAB.
} 
to government]." ${ }^{, 20}$ Kenrick scoffed at Father Perché’s involvement in Louisiana politics. The pro-Confederate priest utilized the Le Propagateur Catholique to advocate the secessionist cause even after "so great a number of men had taken the oath of loyalty" in New Orleans. ${ }^{421}$ Kenrick preferred the course of action endorsed by Bishop Timon of Buffalo, who argued that "Bishops, Priests, and Catholic Journals, should abstain from all ulta expressions ... avoid worldly business, and the strife of parties."422 Timon “deprecate[d] intemperate expressions, from the Catholic clergy, either on the side of Union or on that of Secession," because the bishop believed that the "fever [would] pass." 423 According to Timon, clergy would gain "respect" for the Church if they focused on "the work of God, and, as far as possible, ignore[d] the storm of politics.",424 Clearly, Timon believed that politically-active ministers had contributed to the national crisis, and the bishop of Buffalo sought to limit the Church's involvement in the sectional conflict. Rather, Timon argued that by removing themselves from politics prelates and priests would illustrate the value of Catholicism in maintaining order and promoting peace and neutrality.

The position advocated by Kenrick and Timon constituted the policy adopted by most politicians in the Border States. Following the election of Lincoln until the fall of 1861, many statesmen in the Border South supported a policy of neutrality. Although members of slaveholding states, most Marylanders, Kentuckians, and Missourians demonstrated a commitment to the Union. Culturally tied to the South and politically

${ }^{420}$ Francis Patrick Kenrick to Peter Richard Kenrick, February 28, 1861 in The Kenrick-Frenaye Correspondence, 457.

${ }^{421}$ Ibid.

${ }^{422}$ John Timon to Francis Patrick Kenrick, February 11, 1861, 31-T-49, AAB.

${ }^{423}$ Ibid.

${ }^{424}$ Ibid. 
aligned with the North, many Border State residents viewed neutrality as the proper course of action during the secession period and start of the war. Neutrality meant the preservation of slavery, an aversion to war, and the maintenance of the status quo. ${ }^{425}$ To common citizens and legislators in the region, the policy of neutrality served political, social, and economic purposes that would allow the states to avoid being drawn into a civil war they perceived as the product of extremism that developed in regions farther north and south. For example, historian Thomas C. Mackey compared neutrality to the modern metaphor of a "punt," arguing that Kentuckians "played it safe, played for more time, pursued their own self-interest, and waited." ${ }^{426}$ However, for clergy in the Border States, neutrality corresponded with their religious principles, their anti-war position, and their commitment to an apolitical Church.

For example, Bishop Spalding of Louisville proved one of the strongest supporters of neutrality in Kentucky. On February 27, 1861, Spalding "rejoice[d] at the action of Ky," which convinced him that there would "be no border war, nor civil war of any other kind." ${ }^{427}$ The state's commitment to neutrality led the bishop to believe that "Lincoln ha[d] been, \& [would] be still further, frightened into moderation \& common

${ }^{425}$ For more information about the policy of neutrality in the Border States, see: Jennie Angell Mengel, "The Neutrality of Kentucky in 1861," MA thesis, University of Louisville, 1925; John A. Boyd, "Neutrality and Peace: Kentucky and the Secession Crisis of 1861," PhD dissertation, University of Kentucky, 1999; Thomas C. Mackey, "Not a Pariah, But a Keystone: Kentucky and Secession," in Sister States, Enemy States: The Civil War in Kentucky and Tennessee, edited by Kent T. Dollar, Larry H. Whiteaker, and W. Calvin Dickinson (Lexington: The University Press of Kentucky, 2009); Phillips, 1-16; Harris, 42-158; Louis S. Gerteis, The Civil War in Missouri: A Military History (Columbia: University of Missouri Press, 2012), 4-6, 8-15; Gary R. Matthews, More American than Southern: Kentucky, Slavery, and the War for an American Ideology, 1828-1861 (Knoxville: The University of Tennessee Press, 2014), 225-242.

${ }^{426}$ Mackey, "Not a Pariah, But a Keystone," 34.

${ }^{427}$ Martin John Spalding to John Baptist Purcell, February 27, 1861, II-5-a, CACI, UNDA. 
sense."428 Spalding applauded Kentucky's nonalignment because he believed that it distinguished the state from areas where the radical voices of abolitionism or secessionism had originated. As his letter suggests, the bishop perceived Lincoln and his northern constituents to be aggressive fanatics determined to commence war with the South, rather than individuals of "moderation and common sense."429 Thus, Kentucky's neutral position aligned with the principles of Spalding's faith, which encouraged reason, order, stability, and peace.

During the spring of 1861, Spalding spent much of his time writing the pastoral letter for the Third Provincial Council of Cincinnati, which began on April 27, 1861. In a letter to his metropolitan, Archbishop John Baptist Purcell of Cincinnati, Spalding noted that he would have to "modify" what he had written "in the Pastoral concerning our political crisis." $" 430$ The bishop of Louisville pledged to dedicate a "portion chiefly to an exportation of peace, with a hit at the [Protestant] preachers." 431 Within the same letter, Spalding commended the "immense majority in Ky in favor of maintaining peace, \& the status quo." ${ }^{, 432}$ Tasked with writing the official statement for the Third Provincial Council, Spalding utilized the opportunity to promote peace and neutrality as well as attack Protestant leaders, those whom the bishop believed had helped initiate the national crisis. However, before mailing the letter to Purcell, Spalding added a postscript, which detailed the "pain" he felt over the contents of the "last Catholic Telegraph.",433 "I was

428 Ibid.

429 Ibid.

${ }^{430}$ Martin John Spalding to John Baptist Purcell, April 21, 1861, II-5-a, CACI, UNDA.

431 Ibid.

432 Ibid.

${ }^{433}$ Ibid. 
not prepared to see something more than this," wrote Spalding, "something favoring civil war against southern brethren at the bidding of black republicans."434 In Spalding's opinion, the Catholic Telegraph, Purcell's official diocesan periodical, had breached the Church's apolitical stance by advocating war. In reference to the pro-war sentiment that developed from his metropolitan’s see, Spalding demanded “no more.",435

While attending the Third Provincial Council in Cincinnati, Spalding scoffed at the sight of northerners preparing for war only 100 miles north of his hometown. In a letter to Francis Patrick Kenrick, Spalding noted that "Cincinnati is like a camp," yet he believed that Kentuckians were "determined to resist [any northern] invasion." 436 In his diocesan journal, the bishop described in more detail the state of the Queen City:

Wars \& rumors of wars - Cincinnati a fortified camp[;] all excitement here; daily expect to hear of great battle at Baltimore or Washington. The country is on the verge of dissolution \& ruin. Dona Nobis Pacem [Grant Us Peace]! . . All the Conservatives hope that Ky will remain firm \& neutral as long as possible. ${ }^{437}$

Spalding feared how the preparation for war in the North would impact Kentucky's neutrality. Eleven days after the Third Provincial Council ended, Spalding noted how "rumors of war" continued in the region; however, his "chief hope" remained the "neutrality of Kentucky, which may God preserve!"438 In fact, the prelate believed that the "imminent difficulties" could be "settled without a bloody collision" or "at least without the desolating evils of a protracted civil war."439 However, Spalding perceived

434 Ibid.

435 Ibid.

${ }^{436}$ Martin John Spalding to Francis Patrick Kenrick, May 1, 1861, 37-D-23, AAB.

${ }^{437}$ Spalding Journal, CDBL, UNDA, April 26, 1861, p. 18.

${ }^{438}$ Ibid., May 16, 1861, p. 18.

${ }^{439}$ Martin John Spalding to John Baptist Purcell, May 18, 1861, II-5-a, CACI, UNDA. 
the North's mobilization for war to be an unwarranted action that threatened to ruin the country before negotiations could be reached. In particular, the bishop disparaged the idea of Union Colonel Robert Anderson establishing his headquarters in Kentucky. "I hope you will keep Col. Anderson in Cincinnati," declared Spalding, "his presence here would probably do little good, \& it might do much harm."440 Rather than keeping Kentucky "strictly quiet \& neutral," Spalding anticipated that Anderson's "presence" would "strengthen the secessionists" in his state. ${ }^{441}$

By May 1861, Spalding had proclaimed his commitment to neutrality. The policy aligned with his religious principles, promoted peace, and supported his belief in an apolitical Church. However, the bishop also witnessed firsthand the preparation for war in the North as well as learned about the plan to station Union troops in Kentucky. These experiences reinforced Spalding's belief that Republicans and northern Protestants were immoderate, aggressive radicals. Ultimately, the situation had become clear to the bishop: Lincoln and his evangelical followers wanted war; they sought to carry out a crusade against their religious and political opponents. Meanwhile, Catholics, Kentuckians, and other Border State residents desired peace and compromise. In particular, two letters from the summer of 1861 illustrate well Spalding's interpretation of the North's preparation for war as an act of Protestant aggression. ${ }^{442}$ On May 11, 1861 , Spalding wrote his colleague in Baltimore, offering up prayers for Kenrick and other Catholics in Maryland. After mentioning the "difficulties which surround[ed]" those in

440 Ibid.

${ }^{441}$ Ibid.

${ }^{442}$ For more information about the mobilization for war in the North, see: Russell McClintock, Lincoln and the Decision for War: The Northern Response to Secession (Chapel Hill: The University of North Carolina Press, 2008). 
Baltimore, Spalding opined about the prospects of war in Kentucky. ${ }^{443}$ "Here in Louisville, on the borders," explained Spalding, "we are somewhat anxious.",444 In particular, the bishop wondered "when it may please our modest President [Lincoln] to order his 'northern barbarians' to swoop down upon us, in spite of our neutrality.",445 Spalding's letter to Kenrick indicates clearly his animus toward Lincoln and the president's northern constituents — almost all of whom practiced Protestantism — because the bishop believed they disregarded Kentucky's political nonalignment. The following month, Spalding penned a letter to Jean-Marie Odin, the newly appointed archbishop of New Orleans, in which he continued to discuss his opinion about the war. "We are all here in anxiety about the war," noted Spalding, yet the prelate "trust[ed] that we may soon have peace." ${ }^{446}$ However, Spalding did not believe that peace would develop from political negotiations; rather, the bishop stated that "for this end [peace], I trust that the Yankees will be well and thoroughly beaten."447

Thus, less than two months after he returned from the Third Provincial Council, Spalding's correspondences began to portray a different tone. Prior to his participation in the archdiocesan meeting, Spalding's letters championed neutrality and demonstrated a confidence that peace could be achieved without war. However, his correspondences after May 1861 show how the bishop transitioned from believing in peace through neutrality or compromise to expecting an "invasion" of Kentucky. Furthermore, not only

${ }^{443}$ Martin John Spalding to Francis Patrick Kenrick, May 11, 1861, 37-D-24, AAB.

444 Ibid.

445 Ibid.

${ }^{446}$ Martin John Spalding to Jean-Marie Odin, June 14, 1861, VI-2-d, Archdiocese of New Orleans Collection (hereafter CANO), UNDA. ${ }^{447}$ Ibid. 
did he sneer at Lincoln for refusing to accept neutrality, but Spalding also indicated that he sympathized with the opponents of the North. As he confided to Odin, a fellow Catholic and southerner, Spalding believed that peace would only be restored if the northern army was defeated. Thus, the course of events in the Ohio Valley during the spring and summer of 1861 validated how Spalding and other Border State clergy perceived Lincoln, the Republican Party, abolitionists, and other northern Protestants. Catholics considered evangelicals, antislavery advocates, and the party of Lincoln to be radicals determined to disrupt the status quo. As a result, Spalding and other prelates and priests interpreted the North's mobilization for war and refusal to respect the region's neutrality as hostile actions that drove the nation to war. In short, Border State clergy interpreted neutrality as a "Catholic" policy that advocated peace and compromise while the North's mobilization for war evidenced Protestant or "Puritan" fanaticism.

\section{Clergy and the Commencement of War in the Border South}

"War has commenced," stated Father William H. Neligan, "whilst your city is the battle field, ours is the camp." ${ }^{448}$ Pastor of St. Columba's Catholic Church in Hopewell Junction, New York, Neligan penned the note on April 22, 1861, three days after riots erupted in Baltimore as the $6^{\text {th }}$ Massachusetts Volunteer Infantry traversed the city in route to the nation's capital. According to Civil War historian James McPherson, the following account constitutes the course of events that occurred on April 19, 1861 in Francis Patrick Kenrick’s diocesan see:

On that day the $6^{\text {th }}$ Massachusetts Regiment ... entered Baltimore on its way to Washington. No rail line passed through Baltimore, so the troops had to detrain at the east-side station and cross the city to board a train to the capital. A mob gathered in the path of the soldiers and grew increasingly violent. Rioters

${ }^{448}$ W. H. Neligan to Francis Patrick Kenrick, April 22, 1861, 30-V-1, AAB. 
attacked the rear companies of the regiment with bricks, paving stones, and pistols. Angry and afraid, a few soldiers opened fire. That unleashed the mob ... Maryland flamed with passion. ${ }^{449}$

In response to the event, Baltimore's mayor and chief of police ordered the destruction of several railroad bridges outside the city. Furthermore, several pro-Confederate bands tore down telegraph wires and damaged railroad ties in and around Baltimore. In order to restore order in Maryland's capital, the Union Army arrived, declared martial law in the city, and arrested several suspected secessionists. ${ }^{450}$ A week after the initial riot, the archbishop of Baltimore noted that "[c] onditions in our city are very precarious"; Kenrick had suspended Church activities, including mass, for three days after the riots. ${ }^{451}$ On May 4, 1861, the archbishop wrote to inform Spalding about the event, alerting the bishop of Louisville that the "attack of the troops on the $19^{\text {th }}$ threw our city into great alarm."452 Fortunately for Kenrick and the Catholics of Baltimore, Union troops had not "molested" their "[religious] institutions." religious bigotry" had gotten "mixed up" with the commencement of the war. ${ }^{454}$ Conveying a similar sense of surprise and reprieve, the archbishop informed a friend in Philadelphia that religion had "thus far not entered [the conflict] ... we [Catholics] have suffered no loss up to the present time." ${ }^{, 455}$

${ }^{449}$ McPherson, 285.

${ }^{450}$ Ibid., 285-288.

${ }^{451}$ Francis Patrick Kenrick to M. A. Frenaye, April 26, 1861, in The KenrickFrenaye Correspondence, 476.

${ }^{452}$ Francis Patrick Kenrick to Martin John Spalding, May 4, 1861, 34-K-51, AAB.

453 Ibid.

454 Ibid.

${ }^{455}$ Francis Patrick Kenrick to M. A. Frenaye, April 26, 1861, in The KenrickFrenaye Correspondence, 476. 
Given the archbishop's experiences with anti-Catholic and nativist riots during the antebellum period, Kenrick expected similar events to occur during the Civil War because he interpreted the conflict through a religious lens. Catholic clergy associated the Republican Party and the Union war effort with abolitionists, nativists, and evangelical Protestants, the three groups responsible for inciting anti-Catholic riots during the antebellum period. The perceived relationship between the Lincoln administration and anti-Catholicism combined with the contingency of pro-Confederate Catholics in and around Baltimore led Kenrick to believe that the Union Army would target the Church. ${ }^{456}$ Although Kenrick wrote that "Maryland ha[d] fallen" by lateAugust 1861, the prelate informed his brother that "[n]othing serious [in the way of loss] has thus far come to us [Catholics]. ${ }^{457}$ Perhaps Kenrick and his flock in Maryland avoided having their Catholic institutions targeted because the archbishop demonstrated his loyalty to the Union. Although Kenrick believed that clergy should refrain for mixing politics and religion, the archbishop informed his colleague in Louisville that it might prove necessary during the war. In September 1861, a week after federal officials arrested several suspected secessionist statesmen in Maryland, Kenrick recited a prayer for the Union war effort from his cathedral pulpit. Although the prelate's political

${ }^{456}$ For more information about the Maryland Catholics who sympathized with the Confederacy, see: Spalding, The Premier See, 175-177; Kurtz, Excommunicated from the Union, 34-35; Kenneth J. Zanca, The Catholics and Mrs. Mary Surratt: How They Responded to the Trial and Execution of the Lincoln Conspirator (Lanham, MD: University Press of America, 2008).

${ }^{457}$ Francis Patrick Kenrick to Peter Richard Kenrick, August 23, 1861 in The Kenrick-Frenaye Correspondence, 461. 
actions alienated several pro-Confederate members of his archdiocese, Kenrick deemed the prayer significant for the protection of the Church. ${ }^{458}$

The struggles that the clergy faced during the first months of the war forged a bound between members of the American Catholic hierarchy that crossed geographic regions. For example, a month after Kenrick read the pro-Union prayer in Baltimore, the archbishop corresponded with Patrick Lynch, the bishop of Charleston, South Carolina. After informing Lynch about an acquaintance who had recently died in battle, Kenrick noted that "[w]e sympathize with you in the critical con[quest] of your state." Although Kenrick showed sympathy for clergy in seceded states, he maintained a closer bond with fellow prelates and priests in the Border South. In particular, Kenrick "sympathize[d]" with his brother in Missouri, where Catholics experienced "danger" and "peril" throughout the first year of the war. ${ }^{460}$ In addition to dealing with rioting and military combat within his archdiocese, Peter Richard Kenrick of St. Louis served as the religious leader of a politically divided city and state. As both unionists and secessionists sought the support of the Church, Kenrick urged neutrality and peace. Despite their attempted nonalignment, the Missouri clergy became entangled in the commencement of the war in St. Louis, and, consequently, became a target for religious, ethnic, and political adversaries.

${ }^{458}$ Francis Patrick Kenrick to Martin John Spalding, May 4, 1861, 34-K-51, AAB; Longley, 143-144; Spalding, The Premier See, 175-176; Ellis, 96-97.

${ }^{459}$ Francis Patrick Kenrick to Patrick N. Lynch, October 20, 1861, 34-K-52, $\mathrm{AAB}$. The letter is intact except for the final sentence, which contains a portion that has been removed.

${ }^{460}$ Francis Patrick Kenrick to Peter Richard Kenrick, August 23, 1861; September 7, 1861 in The Kenrick-Frenaye Correspondence, 461, 463. 
In late-1860 and early-1861, bands of secessionists and unionists organized in St. Louis. Branding themselves the "Minute Men," the pro-Confederate group received the support of some Irish Catholics in the city. At the same time, the unionist coalition gained many German followers. As one historian explained, the antebellum contention between Irish Catholics and German Protestants or Freethinkers shaped the sympathies of St. Louis immigrants at the start of the war. Irish Catholics joined the "Minute Men" because they opposed the Republican Party and its German constituents. Likewise, Germans allied with the unionists due to their disdain for Catholicism and the Democratic Party ${ }^{461}$ During the first month of 1861 , both groups sought to allocate the weapons at the federal arsenal in the city. On January 8, 1861, commanding officer of the Missouri Volunteer Militia and secessionist sympathizer, Brigadier-General Daniel M. Frost ordered all men under his command to prepare to assemble to defend the arsenal. Frost indicated that the officers and soldiers should assemble after hearing "'the bells of the churches sounding a continual peal, interrupted by pauses of five minutes." ${ }^{462}$ Rumors spread that Frost had allied with the St. Louis clergy to ring the bells of Catholic churches as a siren for the "'enthusiastic, reckless Irishmen"” to gather at the arsenal. ${ }^{463}$ Although Kenrick denied the accusation, claiming that the prelates and priests of the archdiocese remained neutral, the clergy of Missouri obtained early on the reputation of supporting

${ }^{461}$ White, 52-60. For more information about the contention between Germans and Irish in antebellum St. Louis, see: Luke J. Ritter, "Anti-Catholic America: Nativism and Religious Freedom in the Antebellum West," PhD dissertation, Saint Louis University, 2014. For more information about the German support for the Republican Party during the 1860 presidential election, see: Kristen L. Anderson, "German Americans, African Americans, and the Republican Party in St. Louis, 1865-1872," Journal of American Ethnical History 28 (Fall 2008): 34-51.

${ }^{462}$ Daniel M. Frost quoted in White, 62. ${ }^{463}$ White, 63. 
secession and the Confederacy. As a result, unionists, non-Catholic Germans, and other supporters of the Republican Party in the city distrusted the clergy and questioned their loyalty for the duration of the war. ${ }^{464}$

For example, by early-May 1861, the pro-Confederate state militia under the command of Frost and Governor Claiborne Jackson established a camp in the western portion of the city. After learning about Camp Jackson, Republican congressman Francis Blair of Missouri and Union Captain Nathaniel Lyon collaborated in an effort to rid the state of the pro-secessionist militia. On May 10, 1861, Lyon, commanding a group of federal troops and Missouri "Home Guards" — most of whom were Germanssurrounded Camp Jackson and forced Frost to surrender his troops. During the evacuation of the camp, a crowd assembled and provoked the pro-Union coalition. Unrest commenced and shots were fired, killing twenty-eight members of the crowd. Although several contradictory accounts of the event surfaced, several supporters of Frost's militia blamed the uprising on the German or "Dutch" soldiers. ${ }^{465}$ As one secessionist sympathizer described the Camp Jackson Affair:

The shooting down of 25 private citizens day before yesterday in St. Louis by those infamous German Soldiers - firing by order among men women and children, killing all together - girls 14 yrs. old some ten, and all, has roused the people to a real frenzy. It is awful, awful that foreign mercenaries should be allowed thus to invade, insult and slaughter the citizens of another State! ${ }^{466}$

Rather than blame the event on a particular party, Kenrick adhered to his belief in a neutral Church and argued that a reliance on the principles of Catholicism would

${ }^{464}$ Ibid., 63-68.

${ }^{465}$ White, 70-72; McPherson, 290-292.

${ }^{466}$ Jacob Ditzler Journal, 1860-1866, Kentucky Historical Society, Frankfort, KY, 75. 
prevent future uprisings and civil violence. On May 15, 1861, the archbishop wrote the following to the Catholics of St. Louis:

The deplorable events which have lately occurred admonish me to renew the exhortation I addressed you on a former occasion, and recall to your minds the great principles of our holy religion, as the only effectual means of calming the excitement that prevails . . . banish from your thoughts, as well as from your hearts, every feeling incompatible with the duty of subjecting it to the dictates of reason and religion. ${ }^{467}$

In addition to his call for the restoration of "public tranquility" and the "maint[enance] of order," Kenrick also reminded the members of his flock "that any aggression ... not recognized by law, from which the loss of life may follow, is an act of murder [a sin], of which every one engaged . . is guilty."468 Although Kenrick's message constituted a call for peace and compromise, the St. Louis German press criticized the prelate for not endorsing unionism. On May 16, 1861, the editor of the Anzeiger des Westens scoffed at the "priests" who had "illustrat[ed] to their flocks the view that the rebellion in the Union was chiefly a German concern and that Catholics were to abstain from associating themselves with Germans." 469 Furthermore, the editor claimed that the clergy had "urg[ed] prayers to the patron saint of Ireland to grant them [St. Louis Catholics] greater aid than had been the case at Camp Jackson, and also to protect them during the impending uprising against the Germans." ${ }^{470}$ According to the Anzeiger des Western, not only had the Irish supported the pro-Confederate state militia, but the Church hierarchy in Missouri failed to advocate unionism. Compared to the archbishops of Chicago and

${ }^{467}$ Peter Richard Kenrick quoted in White, 73.

${ }^{468}$ Ibid.

469 The Anzeiger des Westens, May 16, 1861 quoted in Steven Rowan, translator and editor, Germans for a Free Missouri: Translations from the St. Louis Radical Press, 1857-1862 (Columbia: University of Missouri Press, 1983), 224.

${ }^{470}$ Ibid. 
Cincinnati — who the editor claimed had "prayed to Mother Mary to crush the head of the secessionist serpent"-Kenrick and his clergy appeared to be either opportunists, not fully committed to the Union, or Confederate sympathizers because they chose to promote neutrality even after the war had begun. ${ }^{471}$ During the secession crisis, the editor "expected him [Kenrick] to speak out from day to day [in support of the Union]"; however, "there was not a whisper save for dubious and unverified rumors about the archbishop's sympathies.",772 "Finally, after civil war broke out," wrote the editor, the archbishop came "forward with a bunch of commonplaces about reconciliation, and even now he says not one word in favor of the Union, not even one word of reproval against the traitors. ${ }^{, 473}$ In fact, the article blamed the fate of the Irish on the archbishop for not showing "them the right way." "474 Although they were truly "good Union men and brave soldiers," the Irish had been manipulated and misled by devious priests and a craven archbishop. ${ }^{475}$ Thus, for clergy in the Archdiocese of St. Louis, the start of the Civil War involved religious, ethnic, and partisan conflicts. Lay Irish Catholics in the city had joined with the pro-Confederate Missouri Volunteer Militia because they opposed the Republican Party and its German supporters, both of whom had ties to anti-Catholicism and nativism during the antebellum period. As a result, the Church gained the reputation for being sympathetic to secession. By advocating peace and neutrality or failing to publicly endorse the Union — depending on one's perspective-Kenrick reinforced the
${ }^{471}$ Ibid., 226.
472 Ibid., 227.
473 Ibid.
474 Ibid.
475 Ibid., 229. 
perception that Catholics could not be trusted and likely supported the Confederacy. ${ }^{476}$ Furthermore, the archbishop's address to all Catholics in the city following the Camp Jackson Affair constituted what most non-Catholics feared about the Church and its clergy. During the antebellum period, Protestants and Freethinkers charged that prelates and priests restricted the individual rights of conscience of the laity by "telling" them what to think and how to act. Thus, non-Catholics interpreted Kenrick's pastoral as an anti-Union address because the prelate advised or "told" his flock to follow the teachings of the Church and to avoid all occasions of violence. According to the pro-Republican Anzeiger des Westens, by advocating peace, Kenrick undermined the Union war effort, thereby lending support to the secessionists. At the same time, Kenrick faced the pressures of being the religious leader of a divided archdiocese. The prelate's precarious position as well as the principles of his faith led him to promote neutrality, peace, and order. Ultimately, the opposing perceptions of the conflict created a contentious relationship between Missouri clergy and unionists that lasted for the duration of the war and beyond.

As Kenrick entered the tumultuous summer of 1861 in Missouri, Spalding traveled throughout Kentucky, visiting the various parishes, schools, and convents in his diocese. After returning to Louisville in late-June 1861, Spalding suspended publication of the Louisville Guardian. ${ }^{477}$ "The difficulties of the mails South \& other causes

${ }^{476}$ It should be noted that some clergy in the Archdiocese of St. Louis openly supported the Confederacy, thereby confirming the assumptions of many unionists. For more information, see: White, 77-85; William Barnaby Faherty, Exile in Erin: A Confederate Chaplain's Story, The Life of Father John B. Bannon (Saint Louis: Missouri Historical Society Press, 2002).

${ }^{477}$ Spalding Journal, CDBL, UNDA, May 20, 1861-June 17, 1861, p. 18; Spalding, Martin John Spalding, 132. 
growing out of the times have caused us to suspend the publication of the Guardian for some months, until these troubles will be arrayed," explained Spalding. ${ }^{478}$ Within the same letter, the bishop also informed Purcell about the June elections in Kentucky. By the summer of 1861, two parties - the Union Party and the States Rights Party — vied for power in the state. Encompassing conditional and unconditional unionists, the Union Party obtained the support of most Kentuckians. ${ }^{479}$ "Kentucky votes today," wrote Spalding, "\& I have no doubt she will again show her fealty to the Union."480 Although his predictions proved accurate and Kentucky remained in the Union, the state, due to its geographic significance along the border, became the target of both armies during the fall of 1861. As the Union and Confederate armies prepared to enter the "neutral" state, Spalding braced himself for war. On September 27, 1861, Spalding noted that the "first battle [would] probably be fought between 50 \& 60 [?] miles from Louisville," with its "result" determining the "safety" of his diocesan see. ${ }^{481}$ With the prospect of combat near Louisville, Spalding turned to his faith to cope with the anxiety. "God only knows where it will all end," exclaimed Spalding, "our only hope is in the providence of God." 482

As war loomed in the region, Spalding strove to remain apolitical while directing his attention to the care of soldiers on both sides of the conflict. As the bishop explained

\footnotetext{
UNDA.

${ }^{479}$ Lowell H. Harrison and James C. Klotter, A New History of Kentucky (Lexington: The University Press of Kentucky, 1997), 189-190.

${ }^{480}$ Martin John Spalding to John Baptist Purcell, June 20, 1861, II-5-a, CACI, UNDA.

${ }^{481}$ Martin John Spalding to John Baptist Purcell, September 27, 1861, II-5-a, CACI, UNDA. 482 Ibid.
}

${ }^{478}$ Martin John Spalding to John Baptist Purcell, June 20, 1861, II-5-a, CACI, 
in January 1862, " $[\mathrm{m}] \mathrm{y}$ Diocese is cut in two by this unhappy war, and I must attend to souls without entering into the angry political discussion.. ${ }^{483}$ As the religious leader of his diocese, Spalding sought to ensure that Catholic soldiers, regardless of political affiliation, consistently received the holy sacraments. Furthermore, the Church wanted to provide medical assistance to Catholic and non-Catholic soldiers during the war. As a result, throughout the fall of 1861 and winter of 1862, Spalding worked to obtain chaplains and nurses to care for soldiers, including ones of different ethnicities. ${ }^{484}$ For example, the bishop "appointed the Rev. F. Dannis Abarth" to minister to "the Germans" in camps near the Green River. ${ }^{485}$ Cutting through much of south-central Kentucky, the Green River served as the natural boundary that separated the Union and Confederate armies in the state in early 1862 . With Catholics encamped on both sides of the river, Spalding selected "Chaplain General[s]" for both armies, ensuring "that no soul may parish for want of God's ministries. ${ }^{\text {"46 }}$ In fact, in late-January 1862, Spalding spent three days at the Green River camps, where he confirmed forty-eight soldiers and administered "first Communion" to twenty-five. ${ }^{487}$ Overall, the clergy's dedication to both armies reinforced Spalding's belief that Catholicism offered a unifying voice compared to the divisiveness of Protestantism. As the bishop explained in his diocesan journal:

I have endeavored to do my duty towards the poor soldiers, without any reference to exciting political issues. The Catholic Church seeks to save souls, and rises, in

\footnotetext{
${ }^{483}$ Spalding Journal, CDBL, UNDA, January 20, 1862, p. 23.

${ }^{484}$ Ibid., November 1861-February 1862, p. 21-24.

485 Ibid., January 15, 1862, p. 23.

${ }^{486}$ Ibid., January 20, 1862, p. 23.

${ }^{487}$ Ibid., January 21, 1862, p. 23.
} 
her sublime mission, far above the passions of the hour. Deus Providebit pro Suis [God Will Provide for his Family]! ${ }^{488}$

A month after his trip to the Green River, Spalding experienced firsthand the horrors of war. In late-February 1862, the bishop visited the Abbey of Gethsemani, a Catholic monastery near Bardstown, to preach "to the good Monks in French and English. "489 Unable to obtain a seat during the return voyage to Louisville, Spalding rode in the "baggage room" of the train "with 4 corpses of soldiers." event strengthened Spalding's negative opinion of the war because he considered the deaths unnecessary and the conflict in contradiction with his religious beliefs. In a January 1862 lecture at St. Patrick's Church in Louisville, the bishop spoke about the "Heroes \& Heroines of Christianity." 491 Spalding argued that "the Christian who for his true country—heaven—sacrifices goods \& life" constituted the "high[est] type" of hero. ${ }^{492}$ Spalding's lecture differentiated "earthly \& heavenly" heroism, in which the bishop noted that the "causes of the earthly hero [were] dyed in crimson \& his hands drip[ped with] blood."493 The causes of the heavenly hero, however, remained "all immaculate \& immortal, \& if there be blood on his hands it is his own \& not that of his fellow-creatures."494 Spalding's lecture coincided with the start of the war within his diocese. Although he did not specifically mention the conflict, the bishop's message indicates his anti-war posture. Spalding believed that the "earthly" interests of Protestant

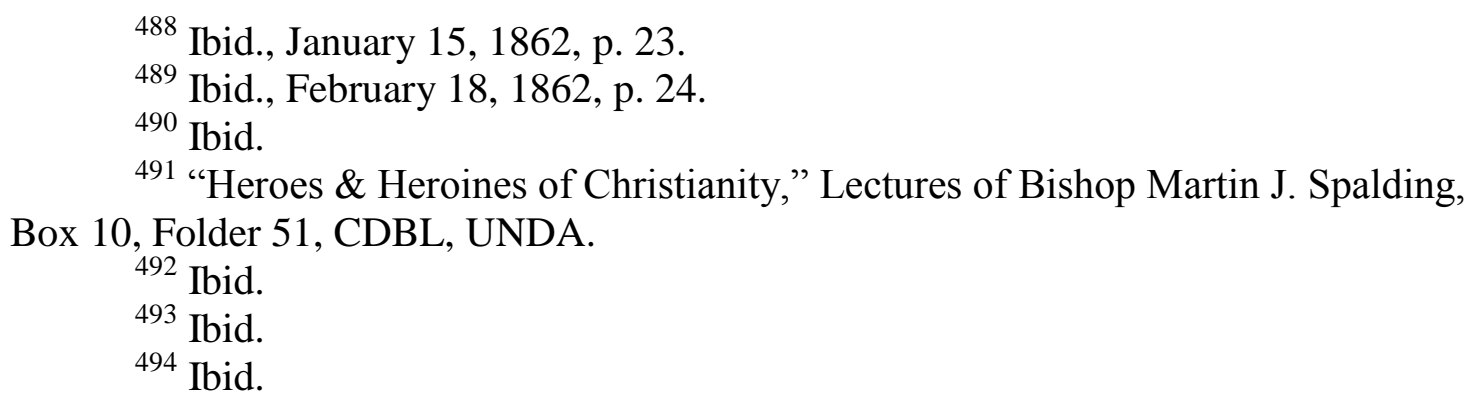


radicals in the North and the South had brought about secession and civil war, leading to the deaths of soldiers and civilians. Based on the content of his lecture, Spalding likely believed that the blood of the four soldiers in the baggage room was on the hands of those preoccupied with mortal causes rather than eternal life. As Spalding explained, the Church denounced the use of violence for worldly pursuits, such as abolition or secession, and directed its members to concentrate on life in heaven rather than on earth. Thus, the Civil War constituted a struggle over earthly disputes - the legality of slavery and secession — therefore, according to Spalding, the conflict should have been avoided.

By September 1862, Spalding noted that the war had come "to a crisis" because the Confederate Army occupied "all [of] central Ky, threatening Louisville." ${ }^{, 495}$ On September 2, 1862, Confederate forces captured Lexington and, on the following day, they occupied Frankfort, the state capital of Kentucky. In response to the Confederate invasion, Union General Lew Wallace took command of Louisville, declared martial law, and suspended all business in the city. Furthermore, Wallace organized a coalition of civilian volunteers and federal troops to construct defenses of the city. Less than three weeks after Wallace's arrival, General William "Bull” Nelson obtained command of all Union forces in Louisville. In anticipation of an attack on the city, Nelson issued an order in late-September, informing residents that they should be prepared to evacuate the city. As a result, panic ensued in Louisville and the bridges to southern Indiana became overcrowded with Kentuckians. ${ }^{496}$

${ }^{495}$ Spalding Journal, CDBL, UNDA, September 3, 1862, p. 38.

${ }^{496}$ Harrison and Klotter, 199-200; Stephen I. Rockenbach, "A Border City at War: Louisville and the 1862 Confederate Invasion of Kentucky," Ohio Valley History 3 (Winter 2003): 35-52. 
Spalding, however, remained in Louisville, vowing to "live \& die with [his] children." 497 Amidst all the "confusion" and "excitement in the city," Spalding offered his assessment and interpretation of the event. ${ }^{498}$ As he explained in his journal:

women and children ordered by Nelson to be ready to leave at a moments notice . .. all confusion - impossible to know the ground of the panic[.] All sorts of rumors afloat, one that the Federals mean to burn the city rather than surrender ... There seems to be remaining little truth among our people, \& what little there is, is hidden from us. ${ }^{499}$

Although the bishop had visited camps, presided over prayer services for the wounded, and been exposed to military corpses, he had never faced a genuine threat against his own life during the war. Not knowing what the following day would "bring forth," Spalding offered a "last will and Testament" to his people: "May our Sweet Mother in heaven smile upon \& protect us this hour of our direst need." ${ }^{~} 500$ Nevertheless, before concluding the entry, Spalding expressed his disdain for Protestantism and explained why its followers were responsible for the war. In his journal, Spalding noted that the:

hypocritical preachers of the North, with their cant about the Bible \& Slavery, have done their work - ruin is their pathway. The innocent must suffer with the guilty, in expiation of their vile hypocracy [sic]! The counterfeit of Religion is worse than no Religion at all ... Protestantism has ruined the country, with its disorganizing principles. ${ }^{501}$

Ultimately, the bishop hoped that "the people who have deluded to their ruin, have the light $\&$ grace to repent and return to their Mother [the Virgin Mary] whom they have... repudiated." ${ }^{502}$ Thus, in the end, Spalding interpreted the potential attack on Louisville, the Confederate invasion of Kentucky, and the entire war as the work of fanatical

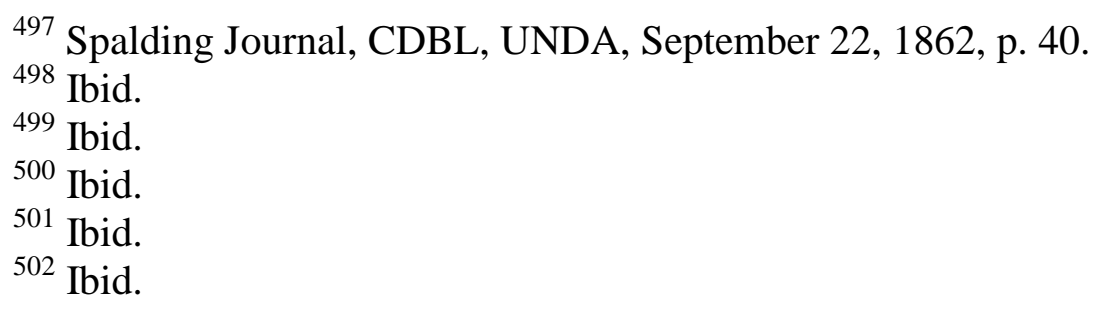


Protestants. According to Spalding, the disorganization, divisiveness, and deceit of Protestantism had led to disunion, destruction, and death. Yet, the bishop did not solely chide his religious adversaries; he also commended Catholicism, arguing that an adherence to Church teachings and principles would have prevented national crisis. The bishop also expected Protestants to recognize the errors of their faith and, after doing so, convert to Catholicism.

\section{$\underline{\text { Conclusion }}$}

By the fall of 1862, the Civil War had commenced throughout the Border South and had impacted each of the diocesan sees in the region. Beginning with the election of 1860 through to the invasion of Kentucky in the fall of 1862, clergy in Maryland, Kentucky, and Missouri interpreted the various events through a religious lens. The clergy's faith and their religious principles shaped their responses to the election of 1860 , the secession crisis, and the start of the war in the region. The majority of Border State prelates and priests supported Stephen Douglas's candidacy, denounced secession, advocated neutrality, and considered the war an unwarranted consequence of religious fanaticism because they believed that Catholicism emphasized peace instead of passion, reason instead of reform, and stability instead of insurrection. Influenced by their antebellum experiences with nativism, anti-Catholicism, and the Catholic apologist movement, Border State clergy interpreted the election of Lincoln, the fragmentation of the Union, the mobilization for war in both regions, and the fighting in their dioceses as evidence of how Protestantism had ruined the country. At the same time, Spalding, the Kenricks, and other clergy from the region argued that if the majority of Americans 
adhered to Catholic teachings and principles then disunion and civil war could and would have been avoided. 


\section{CHAPTER IV}

\section{“SUCH IS THE STATE OF THINGS, NOTHING SHOULD BE ATTEMPTED AGAINST THE LAWS": BORDER STATE CLERGY AND THE DEBATE OVER SLAVERY, ABOLITIONISM, AND WARTIME EMANCIPATION ${ }^{503}$}

In 1860, Francis Patrick Kenrick released the second edition of Theologia

moralis, the archbishop's three-volume manual on the moral theology of the Roman Catholic Church. Originally published in the 1840s, Theologia moralis served as the standard textbook on the subject in the United States. Throughout the mid-nineteenth century, seminaries across the country made Kenrick's work required reading for those studying to become priests. In particular, Theologia moralis constituted an important work for clergy because it provided an interpretation of slavery. During the final two decades before the Civil War, the Vatican made no official statement about slavery in the United States; thus, Kenrick's Theologia moralis served as the guide for American clergy, offering prelates and priests a rationalization for the institution based on Catholic teachings and Church history. ${ }^{504}$ Distinguishing between "the natural law and the law of

${ }^{503}$ Francis Patrick Kenrick quoted in Robert Emmett Curran, Shaping American Catholicism: Maryland and New York, 1805-1915 (Washington, DC: The Catholic University of America Press, 2012), 102.

${ }^{504}$ For more information about Francis Patrick Kenrick's Theologia moralis, see: Joseph D. Brokhage, Francis Patrick Kenrick's Opinion on Slavery (Washington, DC: Catholic University of America, 1955); Leon A. LeBuffe, "Tensions in American Catholicism, 1820-1870: An Intellectual History," PhD dissertation, The Catholic University of America, 1973, 112-120, 140-146; Charles E. Curran, The Origins of Moral Theology in the United States: Three Different Approaches (Washington, DC: Georgetown University Press, 1997), 77-83; W. Jason Wallace, Catholics, Slaveholders, and the Dilemma of American Evangelicalism, 1835-1860 (Notre Dame, IN: University of Notre Dame Press, 2010), 119-133. 
nations," Kenrick deemed slavery a political question that should be decided by statesmen. ${ }^{505}$ Although the archbishop did not consider slavery a "positive good," Kenrick argued that Catholics should adhere to the laws while striving to maintain the institution justly and morally. As the prelate noted in Theologia moralis, "“such is the state of things [slavery], nothing should be attempted against the laws.",506 Ultimately, Kenrick's position on slavery adhered to the Church's tenets regarding the preservation of law, order, and stability in society, all of which Kenrick and other Border State clergy believed abolitionists, northern Protestants, and Republicans threatened to subvert.

This chapter examines how Border State clergy interpreted slavery, abolitionism, and wartime emancipation during the Civil War era. Divided into subsections, the chapter begins with a concise review of the Vatican's position toward slavery during the nineteenth century, underscoring how Catholic leadership in Rome provided little guidance for American clergy regarding the issue. The second subsection explores briefly the historiography of Catholic responses to slavery and emancipation in the United States, revealing how previous historians have interpreted the American Church's defense of human bondage. Scholars have argued that economic interests, racism, and political partisanship led most American Catholics to support slavery or to denounce abolitionism. While this chapter does not deny that those factors shaped how some American Catholics responded to the debate over slavery, it argues that Church teachings and principles proved more significant in determining how Border State clergy rationalized the institution. As a result, the third subsection analyzes in more detail the

\footnotetext{
${ }^{505}$ Wallace, 125.

${ }^{506}$ Francis Patrick Kenrick quoted in Curran, Shaping American Catholicism, 102.
} 
contents of Kenrick's Theologia moralis and explains the archbishop's justification for slavery. Although the prelate defended the institution, Kenrick argued that slaves "had certain rights which no man could take away"; the archbishop also provided instructions for how to maintain slavery justly and morally. ${ }^{507}$ The mid-nineteenth century also witnessed the development of a global Catholic revival, often referred to as the devotional revolution or the rise of devotional Catholicism, which emphasized the suffering of Jesus Christ. The third subsection also considers how the Catholic revival movement influenced the clergy's position toward slavery.

In many ways, Border State clergy defended slavery because they derided the alternative — the free labor system—advocated by Republicans. ${ }^{508}$ Subsection four explores Bishop Martin John Spalding's critique of the North's free market system, which the prelate believed went against Church teachings because it created too much inequality and "fostered 'a spirit of isolation, of individualism, of selfishness, [and] of pride." ${ }^{\circ 09}$ The fifth subsection analyzes the clergy's reactions to and interpretations of abolition and emancipation during the war. In particular, the subsection focuses on the writings of Spalding, who criticized his metropolitan—Archbishop John Baptist Purcell of Cincinnati-for promoting emancipation after 1862. According to Spalding, Purcell and other northern clergy who endorsed Lincoln's policies abandoned Church teachings

${ }^{507}$ LeBuffe, 140.

508 This thesis employs interchangeably the terms "free labor," "free market," and "capitalism" in reference to the Republican Party's ideal economic system. For more information, see: Eric Foner, Free Soil, Free Labor, Free Men: The Ideology of the Republican Party before the Civil War, second edition (New York: Oxford University Press, 1995).

${ }^{509}$ Martin John Spalding quoted in Jon Gjerde, Catholicism and the Shaping of Nineteenth-Century America, edited by S. Deborah Kang (New York: Cambridge University Press, 2012), 239. 
and traditions, and joined northern Protestants in a radical movement that threatened American society. The final subsection analyzes the American hierarchy's position regarding newly freed slaves after 1865, and challenges those historians who have argued that "[a]t the close of the war, the church made little effort on behalf of African Americans in terms of humanitarian relief or evangelization." ${ }^{, 510}$ Although the Church did not organize an official program to provide for freedmen and freedwomen, some clergy - particularly those from the Border States and the South — advocated for the ministry and care of African Americans. The subsection argues that the failure to devise a plan related to the context of the period, when resources for the Church remained limited and the focus of its ministry centered on the Catholic immigrant population concentrated in the North. Overall, the chapter provides an alternative perspective regarding the debate over slavery, abolitionism, and wartime emancipation during the Civil War era. Rather than viewing slavery as a "positive good" that needed to be expanded or a "moral evil" that required immediate eradication, clergy viewed slavery as a "legitimate human relation that could be maintained justly.",511 For Border State clergy, slavery constituted a lived reality protected by state laws and the 1787 federal Constitution and justified by Church teachings. As a result, the prelates and priests believed that northern Protestants who joined the Republican Party and advocated abolition constituted a greater threat to American society than slaveholders. Thus, clergy contended that the Church's position toward slavery preserved peace, respected the law, maintained social order, and benefitted the public good. Concomitantly, the same

${ }^{510}$ William B. Kurtz, Excommunicated from the Union: How the Civil War Created a Separate Catholic America (New York: Fordham University Press, 2016), 106. ${ }^{511}$ Wallace, 119. 
prelates and priests argued that northern Protestants—blinded by their commitment to individualism and reform—-fomented disunion and civil war.

Over Two Decades of Silence from the Holy City, 1839-1864

“"We consider it our pastoral duty,"” wrote Pope Gregory XVI in 1839, “"to make every effort to turn the faithful away from the inhuman traffic in negroes, or any other class of men." ${ }^{12}$ Twenty-two years before the outbreak of the Civil War, the leader of the Roman Catholic Church denounced the slave trade and prohibited Catholics from participating in human trafficking. However, Gregory XVI's In Supremo Apostolatus did not make clear the Church's position toward the institution of slavery. ${ }^{513}$ Some American politicians, nevertheless, portrayed Gregory's apostolic letter as a declaration of the Church's support for abolitionism, prompting Bishop John England of South Carolina to publish a series of letters in the early-1840s that challenged the claim. According to England, the pope "had clearly distinguished between slave traffic and domestic slavery as it existed in the United States. The latter, the bishop insisted, had not been condemned by Rome." ${ }^{514}$ However, in 1843, Irish Catholic leader David O'Connell portrayed the In Supremo Apostolatus as an abolitionist document in order to garner the support of

${ }^{512}$ Pope Gregory XVI quoted in Curran, Shaping American Catholicism, 92-93.

${ }^{513}$ Historians have disagreed about Pope Gregory XVI's true intentions in the In Supremo Apostolatus. For example works that argue Gregory denounced only the slave trade and not the institution itself, see: James J. Hennesey, American Catholics: A History of the Roman Catholic Community in the United States (New York: Oxford University Press, 1981), 145; John T. McGreevy, Catholicism and American Freedom (New York: W.W. Norton \& Company, 2003), 50-52; Wallace, 119-120. For example works that argue Gregory condemned both the slave trade and slavery, see: Joel S. Panzer, The Popes and Slavery (Staten Island, NY: Alba House, 1996), 44-48; Hugh Thomas, The Slave Trade: The Story of the Atlantic Slave Trade, 1440-1870 (New York: Simon \& Schuster, 1997), 665-667; David C. R. Heisser, "Bishop Lynch's People: Slaveholding by a South Carolina Prelate," The South Carolina Historical Magazine 102 (July 2001): 238-239.

${ }^{514}$ Curran, Shaping American Catholicism, 93. 
immigrant Catholics in the United States. O'Connell sought to connect the antislavery movement with the Irish Repeal movement in Europe; however, his efforts failed due to the contention between Irish immigrants and abolitionists in the United States. ${ }^{515}$

According to American Catholic historian Robert Emmett Curran, overall, the "In Supremo had no lasting impact on American Catholic society itself ... the American bishops continued to keep their peace about the issue [slavery] that gradually polarized the country to the point of civil war. ${ }^{, 516}$ Following the death of Pope Gregory XVI in 1846, the Vatican adopted a silent position on the issue of slavery in the United States, responding only to questions directed to the Holy Office. Pope Pius IX, Gregory XVI's replacement, made no public declarations about the slave trade or domestic slavery, in large part because the pope faced an insurrection in the Papal States, which lasted from the late-1840s through to the start of the Civil War. ${ }^{517}$ As Curran explained, following the In Supremo in 1839, both the American Church and the Vatican enacted a "selfimposed gag rule that was extremely effective" in preventing formal divisions within the Church. ${ }^{518}$ As many of the mainstream Protestant denominations in the United States

${ }^{515}$ Ibid., 94-95; John F. Quinn, “"Three Cheers for the Abolitionist Pope!': American Reaction to Gregory XVI's Condemnation of the Slave Trade, 1840-1860," The Catholic Historical Review 90 (January 2004): 67-93. For a general history of the Irish Repeal movement and its connection to abolitionism in the United States, see: Angela F. Murphy, American Slavery, Irish Freedom: Abolition, Immigrant Citizenship, and the Transatlantic Movement for Irish Repeal (Baton Rouge: Louisiana State University Press, 2010).

${ }^{516}$ Curran, Shaping American Catholicism, 94.

${ }^{517}$ Ibid., 102-103; Quinn, 87-88.

${ }^{518}$ Curran, Shaping American Catholicism, 95. Although Curran attributes the "self-imposed gag rule" only to the American Church, the author stated that "[e]xcept for that apostolic letter of 1839, there was little said about slavery" in Rome. For more information, see: Ibid., 102. 
separated into antislavery and proslavery wings during the antebellum period, the American Catholic Church remained united in its position toward slavery. ${ }^{519}$

However, during the third year of the war, Vatican official Vincent M. Gatti filed a report that condemned both slave trading and the institution of slavery practiced in the United States. Gatti determined that the 1861 pastoral authored by Bishop Augustus Martin of Natchitoches, Louisiana was "completely opposed to the teaching of In Supremo Apostolatus and predicated on some fallacious biblical assumptions, such as the blacks being the descendants of Canaan and subject to Noah's curse."520 Furthermore, Gatti argued that American slavery violated the natural liberties of African Americans because it rested upon the assumption that blacks remained inferior to whites. According to Gatti, the Church had accepted slavery as a legitimate relation under certain circumstances; however, Catholic teachings did not justify slavery based on arguments about racial inferiority. As one historian explained, Gatti "admitted that the Church had not condemned every form of slavery in the past, but was certainly opposed to the kind that originated in the unjust deprivation of individual liberty, to the kind that was defended on the ground of some intrinsic difference between whites and blacks." ${ }^{, 521}$ After Gatti filed the report to the Vatican, Pope Pius IX censured the pastoral and directed Bishop Martin to withdraw its publication. If Martin refused the order, the Vatican

${ }^{519}$ For more information about denominations schisms during the antebellum period, see: C. C. Goen, Broken Churches, Broken Nation: Denominational Schisms and the Coming of the American Civil War (Macon, GA: Mercer University Press, 1985); Randall M. Miller and Harry S. Stout, eds., Religion and the American Civil War (New York: Oxford University Press, 1998), 43-88; Mark A. Noll, The Civil War as a Theological Crisis (Chapel Hill: The University of North Carolina Press, 2006); George C. Rable, God's Almost Chosen Peoples: A Religious History of the American Civil War (Chapel Hill: The University of North Carolina Press, 2010), 1-32.

${ }^{520}$ Curran, Shaping American Catholicism, 107. ${ }^{521}$ Ibid. 
vowed to designate the pastoral a forbidden book. Although in 1864 Pius IX criticized Martin's pastoral, the Vatican did not publicly denounce American slavery until 1866, a full year after the Civil War had ended. Furthermore, in 1890, Pope Leo XIII became the first pope to officially condemn both the slave trade and the institution itself. Ultimately, the Vatican's twenty-five year period of silence regarding slavery in the United States meant that American clergy had to deliberate the issue on their own. Thus, Kenrick's Theologia moralis and other appraisals of slavery authored by prelates and priests in the United States proved critical in establishing the American Church's position regarding the institution.

Pro-Profit, Pro-White, Pro-Immigrant, Pro-Democrat Justifications for Slavery

In his article about Pope Gregory XVI's In Supremo Apostolatus, historian John F. Quinn referred to Kenrick as a prelate "who w[as] skilled at mining the pro-slavery aspects of the Church's tradition." ${ }^{, 522}$ The author suggested that the contents of Theologia moralis, which legitimized slavery based on Catholic teachings and Church history, had been deliberately selected by Kenrick because the bishop intended to author a Catholic defense of the institution. In short, Kenrick's Theologia moralis constituted a deterministic effort by a proslavery prelate of the American Church who sought to perpetuate human bondage at the expense of African Americans in order to benefit Catholics in the United States, both native and foreign-born. Similar arguments have been made by other historians to account for the American Church's defense of slavery, its silence regarding the debate over slavery, or its vilification of the abolitionist movement. Historians have argued that the American Church opposed antislavery

${ }^{522}$ Quinn, 92. 
measures because its members benefitted economically from slavery, espoused racial prejudices against blacks, believed that the institution safeguarded the interests of immigrant Catholics, and supported the Democrat Party, which opposed the free-labor Republicans. The following subsection addresses some of the arguments promulgated by historians that account for the American Church's defense of slavery based on economics, racism, immigrant concerns, and political partisanship.

During the antebellum period, several Catholics—clergy and laity—owned slaves throughout all parts of the South. Catholic plantation owners and farmers profited from slave labor, and the American Church used slaves to build churches, seminaries, and convents across the region. In fact, during the first decades of the nineteenth century, the Society of Jesus in Maryland constituted one of the largest slaveholders in the United States. The Jesuits owned plantations operated by slave labor and utilized the revenues from farms, such as White Marsh plantation in Prince George's County, Maryland, to support Catholic ministries in their state and region. However, once the value of their land began to decline during the early nineteenth century, the Jesuits decided to sell the slaves of White Marsh to slaveholders in the Deep South. The proposed sale created a controversy within the Church and drew the attention of Vatican officials. However, after a period of infighting between members of the American hierarchy, the Society of Jesus, and Roman officials, in 1838, the Jesuits of Maryland sold 272 slaves for $\$ 115,000$ to two plantation owners in Louisiana. After allocating $\$ 25,000$ from the sale to pay off debts owed by the archbishop of Baltimore and Georgetown College, the Jesuits used the remaining \$90,000 for future investments. ${ }^{523}$ Similarly, historians have shown how

${ }^{523}$ Hennesey, 144, 147; Curran, Shaping American Catholicism, 30-51, 95-102. 
clergy profited from the exploitation of slave labor in antebellum Kentucky. In 1830, Bishop Benedict J. Flaget, who owned approximately twenty-five slaves, remained one of the largest slaveholders in the state. Furthermore, the Sisters of Loretto, the Sisters of Charity, and other religious orders in Kentucky owned slaves, whom they used to perform essential tasks for the development of their ministries. During the final three decades before the Civil War, St. Mary's College and St. Joseph's College, both located in central Kentucky and directed by members of the Society of Jesus, utilized slave labor to sustain their operations. Clergy at the colleges used slaves as personal servants, to perform construction work, and to labor on nearby farms. Although the Jesuits in Kentucky continued to hire slaves until the final decade before the Civil War, the clergy at St. Joseph's College had sold all of their slaves by 1860 . The clergy's decision to replace the slaves with hired laborers represented the changing economy in the border region. During the late-1850s, many Kentuckians deemed it more profitable to sell their slaves to markets in the Deep South rather than maintain their holdings. ${ }^{524}$ However, as one Catholic historian noted, "the Jesuits probably would not have remained in Kentucky as long as they had if they had not resorted to slave labor."

In addition to arguing that Catholics defended slavery because they profited from slaveholding, historians have also suggested that members of the Church justified human bondage because they believed in white supremacy. In 1857, Frederick Douglas noted that the Irish "were taught at once 'to hate and despise the colored people' when they

${ }^{524}$ C. Walker Gollar, "Jesuit Education and Slavery in Kentucky, 1832-1868," Register of the Kentucky Historical Society 108 (Summer 2010): 213-249; C. Walker Gollar, "Catholic Slaves and Slaveholders in Kentucky," The Catholic Historical Review 84 (January 1998): 42-62.

525 Gollar, "Jesuit Education and Slavery in Kentucky," 249. 
arrived 'in this christian country." ${ }^{9526}$ Historians have documented the contention that existed during the antebellum period between working-class immigrant Catholics and African Americans. Both groups viewed the other as a threat to their social, economic, and political status in the United States. Not only did Douglas note the Irish prejudices toward African Americas, but he expressed his own anti-Catholic biases. For example, Douglas referred to Catholicism as a religion of "cunning illusions"” that "threatened the integrity of American institutions. ${ }^{, 527}$ Racial tensions from the antebellum period continued during the war. For example, William B. Kurtz stated that Catholic soldiers in the Union Army "believed that blacks were inferior to whites and wanted little to do with abolition. ${ }^{, 528}$ As he explained, bigoted Catholics wavered in their support for the Union after 1863. Following the issuance of the Emancipation Proclamation, many Catholicsparticularly immigrants — conveyed opposition to the war because it involved emancipation and black recruitment. ${ }^{529}$ In particular, John Mullaly, editor of the Metropolitan Record of New York, proved one of the loudest Catholic critics of the Lincoln administration and emancipation during the Civil War. Originally advertised as a "'good Catholic family paper,"” the Metropolitan Record transformed into one of the leading Copperhead publications during the final three years of the war. ${ }^{530}$ "By the summer of 1862," wrote author Joseph George, "[John] Mullaly’s Record had come to resemble an anti-administration journal. Lincoln's Emancipation Proclamation in

${ }^{526}$ Frederick Douglas quoted in Gjerde, 246.

${ }^{527}$ Ibid., 248.

${ }^{528}$ Kurtz, Excommunicated from the Union, 63.

529 Ibid., 63-67.

${ }^{530}$ John Mullaly quoted in Joseph George, Jr., "“A Catholic Family Newspaper' Views the Lincoln Administration: John Mullaly's Copperhead Weekly," Civil War History 24 (June 1978): 114. 
September would cause the Record to surrender its claims to non-partisanship, lose its status as Archbishop Hughes' 'Official Organ,' and become one of the leading, or notorious, Democratic newspapers of the North. ${ }^{, 531}$ Mullaly's periodical criticized Lincoln's antislavery policies, the enlistment of African American troops in the Union Army, and the conscription of Catholic soldiers. Furthermore, the Metropolitan Record supported a peaceful end to the war with Confederate independence and backed Democratic candidate George B. McClellan in the 1864 presidential election. As one historian explained, Mullaly adopted the Copperhead platform because the editor "was motivated by racism ... an intense dislike of Negroes, emancipation, and abolitionists. ${ }^{, 532}$

Historians have also argued that the American Church justified slavery because Catholics believed that maintaining the institution protected the interests of immigrant followers. In particular, many Catholics assumed that if slaves remained in bondage in the South then they would not compete with Irish and German free laborers in the North. On several occasions during the antebellum period, immigrant workers rioted when they felt that their positions might be replaced by slave or free black labor. Similar events occurred during the war. For example, in the summer of 1862, anti-black riots erupted in several northern cities, as immigrant laborers feared the infiltration of freed slaves into the North. ${ }^{533}$ Archbishop John J. Hughes represented the sentiments of most Catholics at

531 Ibid., 119.

532 Ibid., 128.

${ }^{533}$ Gjerde, 246-248; James M. McPherson, Battle Cry of Freedom: The Civil War Era (New York: Oxford University Press, 1988), 507; Daniel Walker Howe, What Hath God Wrought: The Transformation of America, 1815-1848 (New York: Oxford University Press, 2007), 433-435; Mischa Honeck, We Are the Revolutionists: German- 
the time when he stated that "we . . have not the slightest idea of carrying on a war that costs so much blood and treasure just to gratify a clique of Abolitionists." "534 Hughes noted that northern Catholics, both native and foreign-born, would support a war for the restoration of the Union; however, the same Catholics would not fight for the eradication of an institution that they believed protected their economic interests. Furthermore, the Church's pro-immigrant posture meant that most American Catholics supported the Democratic Party at the time of the Civil War. Historians have shown how the proimmigrant and anti-antislavery politics of the Democratic Party benefited members of the Church. As a result, historians have concluded that Catholic participation in the Democratic Party - the party of slavery — meant that almost all clergy and lay leaders defended the institution both before and during the war. ${ }^{535}$

Combining the issues of economics, race, and politics, Michael Hochgeschwender has provided the most recent and thorough examination of the American Church's position toward slavery and abolitionism. According to Hochgeschwender, American Catholics—-both clergy and laity—worried foremost about their own security and assimilation in the United States. As a minority religious group that often faced their own prejudices, Catholics responded to the debate over slavery and emancipation in ways that they believed benefitted their own place in American society. For example, Catholics opposed the abolitionist movement because its leaders espoused both antislavery and anti-Catholic sentiments. Furthermore, Church members joined the

Speaking Immigrants \& American Abolitionists after 1848 (Athens: University of Georgia Press, 2011), 76-78.

${ }_{534}$ John J. Hughes quoted in McPherson, 507.

535 Gjerde, 154-156, 254-256; McPherson, 30-33; Kurtz, Excommunicated from the Union, 26-31; Wallace, 16-17; David Goldfield, America Aflame: How the Civil War Created a Nation (New York: Bloomsburg Press, 2011), 89-91. 
Democrats because the party opposed the nativist and antislavery policies of the KnowNothings and Republicans, as well as promised to protect the interests of immigrant Catholics in the United States. As Irish and German Catholics struggled to obtain employment and assimilate into nineteenth-century American society, they feared the ramifications of Protestant-led reform movements, such as abolitionism, temperance, and nativism. Catholics believed that abolitionist efforts threatened their economic security, the temperance movement undermined their cultural values, and nativists thwarted their assimilation and participation in American society. ${ }^{536}$ Overall, clergy in the American Church sought to "provide cohesion and stability for its relatively small number of traditional adherents as well as for the great burgeoning of Irish and German immigrants who poured into the country [during] the 1840s. ${ }^{, 537}$ In short, Hochgeschwender concluded that prelates and priests opposed the antislavery movement because they believed that it would prove more detrimental than beneficial, particularly for the American Catholic community. As explained by Hochgeschwender's reviewer, religious historian Mark A. Noll, "Catholics remained more concerned about the threat of radical reform than the abuses of the slave system." ${ }^{538}$ Noll stated that "the Catholic church's main goals were conservative, as expertly summarized in the title of [Hochgeschwender's] book: Wahrheit, Einheit, Ordnung" "- truth, unity, and order . ${ }^{539}$

${ }^{536}$ Mark Noll, review of Wahrheit, Einheit, Ordnung: Die Sklavenfrage und der amerikanische Katholizismus 1835-1870, by Michael Hochgeschwender, Theologische Literaturzeitung 133 (2008): 834-836; Michael Hochgeschwender, Wahrheit, Einheit, Ordnung: Die Sklavenfrage und der amerikanische Katholizismus 1835-1870 (Paderborn: Ferdinand Schöningen, 2006). Due to the author's inability to read German at this time, this thesis relies exclusively on the contents of Noll's review.

${ }_{537}^{537}$ Noll, review of Wahrheit, Einheit, Ordnung, 835.

${ }^{538}$ Ibid.

${ }^{539}$ Ibid. 
Noll's use of the term "conservative" refers to its literal definition. Clergy sought to conserve the status quo — which included slavery—because they believed that reform threatened the American Catholic Church, its followers, and society in general.

This thesis does not deny that economics, racism, immigrant concerns, and political partisanship shaped how many Catholics—-particularly Irish and German immigrants — responded to the nineteenth-century debates over slavery, abolitionism, and wartime emancipation. In fact, Hochgeschwender's efforts to address all of the factors, combined with an appreciation of Catholic teachings about slavery, in one work demonstrates the true complexity of the topic. However, rather than analyzing both Catholic clerics and laity, as did Hochgeschwender, the remaining subsections of this chapter address the factors that proved most influential in shaping the clergy's interpretations of slavery. By focusing on their theological defense of the institution, the impact of nineteenth-century devotional Catholicism — which emphasized suffering as an important aspect of piety—-the clergy's criticisms of capitalism, and the ways in which anti-Protestantism or the Catholic apologist movement influenced their rationalization of slavery, the chapter underscores what differentiated prelates and priests from other proslavery apologists or anti-antislavery leaders of the era. Economics, racial prejudices, and political partisanship determined why most white Americans either supported slavery or condemned abolitionism. However, the clergy's adherence to and promotion of Catholicism as well as their disdain for and denouncement of Protestantism proved the most influential factors in determining the Border State hierarchy's justification for slavery during the Civil War period. 
The Clergy's Moral Theology, the Rights of Slaves, and Devotional Catholicism

"Official Catholic doctrine" of the nineteenth century, stated historian John Tracy Ellis, "held that slavery was not necessarily evil; it taught that slavery, thought of theoretically and apart from specific human dignity, was not opposed to the divine or natural law." ${ }^{540}$ During the antebellum period, Kenrick's Theologia moralis was responsible for disseminating the argument made by Ellis to Catholic clergy and lay leaders throughout the United States. In addition to Bishop John England's letters that justified slavery, Kenrick's Theologia moralis constituted the American Church's most important theological and theoretical text on the subject before the Civil War. Overall, Kenrick's manual on Catholic moral theology indicated that the Church had maintained a tradition of slavery, contended that slavery did not oppose natural law, taught that slavery existed to provide a greater benefit to members of society, and advised Catholics to adhere to all laws that permitted slavery.

In particular, the principles of Saint Thomas Aquinas influenced the contents of Kenrick's Theologia moralis because the prelate "utilized Aquinas's distinction between the natural law and the law of nations." ${ }^{541}$ According to Aquinas and Kenrick, "the jurisdiction of slavery belonged to the jus gentium voluntarium, or the laws of social regulations that nations observe out of a sense of equity or justice. ${ }^{, 542}$ Although natural law recognized that "all men are indeed morally equal," Kenrick argued that "the state had a warranted yet imperfect relationship with the natural law." ${ }^{543}$ Kenrick compared

540 John Tracy Ellis, American Catholicism, second edition (Chicago: The University of Chicago Press, 1969), 89.

${ }^{541}$ Wallace, 125.

542 Ibid.

543 Ibid. 
the existence of slavery to the state's role in managing the procurement and possession of other forms of property in society. "[B]y general agreement and consent," states often "abrogate[d] freedom to fulfill its obligation to the common good." viewed slavery - albeit "a consequence of sin and the disorder generated by sin"-as the result of a state's imperfect association with natural law and as a political plan designed to provide for the general welfare of society. ${ }^{545}$

In addition to the principles of Thomas Aquinas and other Catholic theologians, the context of antebellum America influenced the arguments in Theologia moralis. As Kenrick explained, "his moral theology was intended to address difficulties arising from a society of citizens 'with no religious bond in common,' who are free 'to follow each his own conscience. ${ }^{\prime 546}$ Without an established moral authority in the United States, such as the Roman Catholic Church, Kenrick's Theologia moralis referenced American law as the agreed upon guide for how clergy should respond to the institution of slavery. As one historian explained, Kenrick's "knowledge of American legislation appears throughout the book ... He frequently cites Sir William Blackstone, Kent's Commentaries, Purdon's Digest as well as the laws of the individual states. ${ }^{, 547}$ In 1843, the year of the first edition of Theologia moralis, Kenrick served as bishop of the Diocese of Philadelphia. Although Pennsylvania had passed a gradual abolition act in 1780, Kenrick's moral theology appealed to the national law, and the Constitution recognized the legality of

544 Ibid.

545 Ibid.

${ }^{546}$ Francis Patrick Kenrick quoted in Ibid, 124.

${ }^{547}$ Curran, The Origins of Moral Theology in the United States, 78. 
slavery. ${ }^{548}$ In fact, Kenrick added a fourth condition to the Church's philosophy concerning whom could "rightfully be kept in a state of slavery." origin of the Church, the Roman hierarchy had taught that "men captured by a victorious nation in a just war, men who sold themselves into slavery, and men who had committed a crime could rightfully be enslaved." 550 However, influenced by American laws and customs, Kenrick "added a fourth category: those born into slavery . . . could be morally kept in the state by their masters.",551 According to one Catholic historian, "Kenrick admitted that those Africans brought to the Americas by slave traders had been enslaved wrongly" — a statement that coincided with Gregory XVI's In Supremo Apostolatus"[b]ut, he held, their descendants in America could be held in slavery without any sin on the part of the masters." ${ }^{, 52}$ Overall, Kenrick's rationalization for maintaining slavery in the United States demonstrates his and other clergy's “desire to uphold law, order, and stability in American society." 553

In particular, the influence of Theologia moralis can be identified in American Catholic reactions to the 1857 Dred Scott decision. ${ }^{554}$ According to historian William B. Kurtz, Justice Roger B. Taney's Catholic faith shaped his opinion of the case. "Though he had manumitted his own slaves," wrote Kurtz, "Taney saw the Republican Party and

${ }^{548}$ For more information about the history of slavery and abolitionism in Pennsylvania, see: Gary B. Nash and Jean R. Soderlund, Freedom by Degrees: Emancipation in Pennsylvania and its Aftermath (New York: Oxford University Press, 1991).

${ }^{549}$ LeBuffe, 141.

${ }^{550}$ Ibid.

551 Ibid.

552 Ibid.

${ }^{553}$ Kurtz, Excommunicated from the Union, 91.

${ }^{554}$ For more information about the Dred Scott decision of 1857, see: McPherson, 170-181; Goldfield, 139-156; William W. Freehling, The Road to Disunion: Secessionists Triumphant, 1854-1861 (New York: Oxford University Press, 2007), 109-122. 
abolitionists alike as threats to the South [and the country]. Thus he sought to use the Court to end the slavery debate once and for all" to restore order in American society. ${ }^{555}$ Furthermore, the contents of Kenrick's moral theology continued to direct Catholic opinion about slavery until the time of the Civil War. On January 28, 1860, the Louisville Guardian—Bishop Spalding's official diocesan periodical—stated: “we do not deny that there are Catholics who are opposed to the institution of slavery, but we do deny that there are any who are ready to trample on the Constitution of the country to effect a change in the relationship between the master and the slaves." 556 Both Taney and the editor of the Louisville Guardian considered the Constitution or American lawrather than emotion or radical religion - as the benchmarks that should be used to decide the fate of slavery in the United States, an important tenet outlined in Kenrick's Theologia moralis. Likewise, Florida Bishop Augustin Verot's January 1861 sermon about slavery underscored its legality. Verot criticized antislavery advocates who disregarded the Constitution and, in doing so, threatened disunion. ${ }^{557}$ Eight months after he "render[ed] it lawful" in his Florida sermon, Verot traveled to Louisvlle, Kentucky to preach in the city's cathedral. ${ }^{558}$ On August 10, 1861, Spalding reported Verot's visit in his official diocesan journal. Although the Louisville prelate did not comment on the contents of Verot's sermon in Kentucky, the Florida bishop probably delivered a message

${ }^{555}$ Kurtz, Excommunicated from the Union, 91.

${ }^{556}$ Louisville Guardian, January 28, 1860 quoted in Kenneth J. Zanca, ed., American Catholics and Slavery: 1789-1866, An Anthology of Primary Documents (Lanham, MD: University Press of America, 1994), 133.

${ }^{557}$ Augustin Verot to Francis Patrick Kenrick, January 18, 1861, 32-D-6, Associated Archives at St. Mary's Seminary and University, Baltimore, MD (hereafter AAB); Augustin Verot, A Tract for the Times: Slavery \& Abolitionism, Being the Substance of a Sermon, Preached in the Church of St. Augustine, Florida, on the $4^{\text {th }}$ Day of January, 1861 (New Orleans, LA: Catholic Propagator Office, 1861).

${ }^{558}$ Augustin Verot to Francis Patrick Kenrick, January 18, 1861, 32-D-6, AAB. 
similar to his January 1861 address, which advised Catholics to uphold the law regarding slavery. ${ }^{559}$ Undoubtedly, Kenrick's Theologia moralis—particularly the text's emphasis on adhering to the law as a way to maintain order and stability in society—influenced how fellow clergy in the Border States as well as prelates and priests throughout the country interpreted the debate over slavery, abolition, and wartime emancipation.

Kenrick's moral theology would be considered "cruel by today's standards," noted one scholar. ${ }^{560}$ The same historian described the prelate as "meticulous, scholarly, and passionless," suggesting that the arguments in Theologia moralis reflected the character of Kenrick. ${ }^{561}$ In particular, the author argued that Kenrick remained a product of both an intense dedication to the Catholic hierarchy and the predominant social and cultural values of antebellum America. Kenrick viewed his role as an American prelate as the protector and promoter of Church authority. Following the lead of the Vatican, Kenrick opposed nineteenth-century radical or liberal reform movements, such as abolitionism in the United States or attempts to create a unified, independent, and democratic Italian state. Like Pope Pius IX and other Roman officials, Kenrick linked liberalism with anti-Catholicism and believed that if the Church's authority diminished then social disorder and irreligion would spread around the world. ${ }^{562}$ Furthermore,

559 Journal of Martin John Spalding, Bishop of Louisville, April 8, 1860-March 27, 1864 (transcript), Box 10, Folder 9, Archdiocese of Louisville Records (hereafter CDBL), University of Notre Dame Archives, Notre Dame, IN (hereafter UNDA), August 10, 1861, p. 20. Peter E. Hogan transcribed the journal in April 1950 and provided a copy to the University of Notre Dame Archives. The original diocesan journal is located in the Department of Archives and Manuscripts, Mullen Memorial Library, Catholic University of America, Washington, DC The transcript will be cited hereafter as (Spalding Journal, CDBL, UNDA).

${ }^{560}$ LeBuffe, 112.

561 Ibid.

${ }^{562}$ Ibid., 113, 116-118. 
"Kenrick was unwilling or perhaps even incapable of applying his Catholic beliefs to any plan for fulfilling the corporal works of mercy, or of even concerning himself about man's physical needs.. ${ }^{, 53}$ The prelate's public and private writings include no "plea for the poor, no concern about housing or jobs, or the general welfare of his poor people." 564 According to Catholic historian Leon A. LeBuffe, Kenrick possessed the "blindness to social problems ... shared by most Jacksonian Americans"; furthermore, the clergyman did not fit into one of the three categories of reformers during the period: "negativistic attempts to abolish something ... utopian schemes based on a single idea or panacea ... [or] attempts to improve the lot of society's obviously unfortunate members.. ${ }^{.565}$ Most importantly, Kenrick did not consider the Church an institution dedicated to the betterment or advancement of a particular class in society; rather, he thought that clergy should devote their energies to safeguarding the interests of the Church from antiCatholic and other radical reformers as well as to missionary efforts to bring more people into the Church. As LeBuffe explained, Kenrick "shared the notion that religion was a rather genteel thing, properly concerning itself with saving men's souls ... religion was not involved with ... "living conditions." 566 Thus, much of Kenrick's Theologia moralis and his arguments about slavery were shaped by the prelate's devotion to the Roman Church as well as the predominant social and cultural values of antebellum America.
${ }^{563}$ Ibid., 114.
564 Ibid.
565 Ibid.
${ }^{566}$ Ibid., 117. 
Despite Kenrick's dispassionate demeanor and his moral theology that accepted slavery, he argued that slaves "had certain rights which no man could take away." 567 Kenrick required slaveholders to provide food - albeit coarse rather than fine food — for slaves, to educate their slaves in the Catholic faith, and to ensure that all slaves received the holy sacraments of baptism, communion, and marriage. Although Kenrick wrote that slaves should be punished for defying orders, the prelate argued that slaveholders should not torture or brutally punish their slaves. Furthermore, Kenrick denounced the slave trade and discouraged owners from selling their slaves. However, if a sale proved necessary, Kenrick urged slaveholders to avoid separating families and to ensure that Catholics slaves remained with Catholic masters. ${ }^{568}$ Kenrick's arguments about the rights of slaves and the responsibilities of Catholic slaveholders can be identified in the private and public writings of clergy during the antebellum and Civil War periods. Several letters written in the 1850s by clergy in the Diocese of Louisville to Vicar-General Benedict J. Spalding, brother of the bishop, include requests for dispensations ${ }^{569}$ to marry slaves. For example, in 1851, Father F. B. Jamison requested a dispensation to marry "the servant girl of Mr. Ja[me]s Clarke" and "a negro man not baptized."570 Jamison had

${ }^{567}$ Ibid., 140.

${ }^{568}$ LeBuffe, 140; McGreevy, 53.

${ }^{569}$ A privilege granted by a high-ranking cleric in the Roman Catholic Church that provides authorization to conduct an act that defies existing Church doctrine or law. For example, a dispensation would need to be granted for a priest to solemnize a marriage between a baptized Catholic and a non-Catholic.

${ }^{570}$ F. B. Jamison to Benedict Joseph Spalding, [September] 28, 1851, Box 1, Folder 50, Benedict Joseph Spalding Papers (hereafter CBJS), UNDA. For other examples of requests for dispensations to marry slaves, see: John B. Hutchins to Benedict Joseph Spalding, November 3, 1852, Box 1, Folder 48, CBJS, UNDA; Charles I. Coomes to Benedict Joseph Spalding, November 13, 1852, Box 1, Folder 16, CBJS, UNDA; Anthanasius A. Aud. [?] to Benedict Joseph Spalding, June 31, 1853, Box 1, Folder 1, CBJS, UNDA. 
obtained the "consent" of "the masters"; thus, he planned to marry the slaves once he received the dispensation from Spalding. ${ }^{571}$

Other letters from the period highlight the clergy's concern for ensuring that slaves obtained the other holy sacraments. While visiting a Catholic community in New Madrid, Missouri in January 1852, Father Jamison wrote that the "poor negroes ha[d] been entirely overlooked." ${ }^{572}$ As a result, the priest decided to prepare "some ten or fifteen ... for ba[p]tism," in addition to allowing the "youngsters" to attend "Catechism" lessons. ${ }^{573}$ "I say mass every day if the weather permits," wrote Jamison, and "preach in the morning and give Catechism in the evening of Sundays and then take chances to catch the grown folks, white or black[,] whenever I can." ${ }^{\text {574 }}$ Although Father Joseph P. Machebeuf claimed that "many masters take good care of their slaves and many of the latter would not want to leave them if freedom were [o]ffered," the priest described slave sales as "revolting scene[s]." 575 While in Memphis, Tennessee, Machebeuf witnessed a "negro-vendor" sell "two poor young negresses to a merchant of that city." 576 "He examined them, made them walk and talk," wrote Machebeuf, "asked them what they could do and why their masters had sold them. Finally deciding that they could be useful for the value of his money, he bought them.",577 Machebeuf concluded that "[i]t was really sad to see them walking slowly behind their master, these poor girls covered with

${ }^{571}$ Ibid.

${ }^{572}$ F. B. Jamison to Benedict Joseph Spalding, January 29, 1852, CBJS, UNDA. 573 Ibid.

574 Ibid.

${ }^{575}$ Joseph P. Machebeuf to his sister, January 17, 1851 (translated and transcribed), Box 1, Folder 3, Machebeuf Papers, Sisters of Loretto Archives, Loretto Heritage Center, Loretto Motherhouse, Nerinx, KY.

576 Ibid.

577 Ibid. 
rags."578 Finally, evidence of Kenrick's Theologia moralis can be identified in Verot's January 1861 sermon. Just as Kenrick outlined the rights of slaves and responsibilities of Catholic slaveholders in his moral theology, Verot's sermon stated that "masters must promote morality among slaves, $\&$ have the marriage laws observed . . \& not separate families, treat them proudly \& give them an opportunity of knowing religious truth."579 Ultimately, the clergy's letters from the antebellum and Civil War periods indicate that Kenrick's Theologia moralis had a profound effect on how members of the American Church viewed slavery. Jamison, Verot, and other clergy sought to ensure that slaves received the holy sacraments and to safeguard their rights as defined by Kenrick. Furthermore, Machebeuf's description of the slave sale in Memphis serves as an example of the clergy's disdain for the slave trade, a practice discouraged by Kenrick and Gregory XVI.

In addition to Kenrick's moral theology, the Catholic revival or the devotional Catholicism movement influenced how clergy interpreted the institution of slavery in the United States. According to Catholic historian Jay P. Dolan, during the nineteenth century, devotional Catholicism "enjoyed a renaissance," so that by the 1850 s "it had become a distinctive feature of American Catholicism.. ${ }^{, 50}$ In particular, the Catholic revival included three central components: an importance placed on the teachings of Saint Thomas Aquinas, an emphasis on the suffering of Jesus Christ, and the development of

578 Ibid.

579 Augustin Verot to Francis Patrick Kenrick, January 18, 1861, 32-D-6, AAB; Augustin Verot, A Tract for the Times: Slavery \& Abolitionism, Being the Substance of a Sermon, Preached in the Church of St. Augustine, Florida, on the $4^{\text {th }}$ Day of January, 1861 (New Orleans, LA: Catholic Propagator Office, 1861).

${ }^{580}$ Jay P. Dolan, In Search of an American Catholicism: A History of Religion and Culture in Tension (New York: Oxford University Press, 2002), 52. 
Catholic schools, orphanages, and other institutions, or what one historian has called the creation of a "Pillorized Catholic World." ${ }^{581}$ Devotional Catholicism became popular in the United States during the antebellum period due to the increase in Catholic immigration to the country. The hardships that Irish and German immigrants faced—in both the Old and New Worlds - provided a genuine substantiation for the movement. As many Catholic immigrants experienced religious prejudice and impoverished living conditions in antebellum America, prelates and priests made popular the oration of the sorrowful mysteries of Jesus Christ, participation in the stations of the cross, which recalled Christ's sufferings on the day of his crucifixion, and the dissemination of images that depicted a wounded heart crowned with thorns. ${ }^{582}$

Furthermore, the Catholic revival was closely connected to ultramontanism, an ecclesiastical conception among Catholic clergy that emphasized "heightened respect for church authorities ranging from the pope to parish priests. ${ }^{~} 583$ In short, ultramontanes valued the hierarchy of the Church and remained devoted followers of the pope and his Vatican officials. Similar to the sentiments of Pope Pius IX, American ultramontanes derided nineteenth-century reform movements, such as abolitionism. Regarding the effects of devotional Catholicism on the American Church's evaluation of slavery, religious historian Mark A. Noll wrote the following:

[B]y the mid-nineteenth century Catholics [shared a] general attitude that worked against a reformist mentality. It was an attitude nourished by the great nineteenth-

${ }^{581}$ McGreevy, 25; Gjerde, 156.

${ }^{582}$ Gjerde, 234-237; McGreevy, 28-29; Jay P. Dolan, The American Catholic Experience: A History from Colonial Times to the Present (New York: Doubleday \& Company, 1985), 228-238.

${ }^{583}$ McGreevy, 13. 
century revival in devotional piety that looked upon human suffering not just as a problem to be fixed but also as a condition to be embraced for spiritual good. ${ }^{584}$

Noll compared the predominant Catholic interpretation of slavery with the view of most northern Protestants during the period. As he explained:

It had long been habitual for American Protestants to approach Christian life in the world with an activist mentality. Especially the broad Reformed, or Calvinist, tradition - which shaped Congregationalists, Presbyterians, Baptists, Restorationists, and even Episcopalians and Methodists - looked upon problems as challenges to be solved ... Obstacles impeding the advance of God's Kingdom should and could be identified, assessed, and eliminated. ${ }^{585}$

Compared to many northern Protestants, who sought to eradicate forms of suffering, such as slavery, Catholics viewed human anguish as a travail that demonstrated one's piety and nurtured the individual's relationship with God. In fact, many American clergy underscored a similarity between the suffering of immigrant Catholics and slaves. Rather than differentiating between the two, prelates and priests viewed both as examples of suffering that coincided with the devotional Catholicism movement. Instead of mobilizing against slave suffering, Catholics viewed it as "one of those intractable human conditions to be borne patiently for the sake of eternal reward."586 Thus, in addition to Kenrick's Theologia moralis, the tenets of the nineteenth-century Catholic revival shaped how American clergy interpreted the institution of slavery.

Catholic Corporatism with Slavery Rather than Protestant Individualism with Inequality

“Catholics understood freedom differently,” wrote Catholic historian John T. McGreevy. 587 "If nineteenth-century liberals idealized human autonomy," he explained,

${ }^{584}$ Mark A. Noll, The Civil War as a Theological Crisis (Chapel Hill: The University of North Carolina Press, 2006), 131.

585 Ibid.

586 Ibid., 132.

${ }^{587}$ McGreevy, 36. 
"Catholics habitually referred to communities." ${ }^{" 588}$ McGreevy's assessment of Catholic understandings of freedom explains why many clergy, particularly Bishop Martin John Spalding of Louisville, criticized the free labor system promulgated by Republicans at the time of the Civil War. Shaped by their commitment to collectivism, Spalding and other Catholic leaders "fostered a corporate ideal that mitigated against individual excesses in the polity and economy." ${ }^{\circ 89}$ Clergy believed that Catholic corporatism constituted a superior alternative to the free market system that northern Protestants promoted. Prelates and priests identified slavery as an appropriate element of their corporate ideal because they believed it offered African Americans protection against the perceived greed and exploitation that capitalism produced. As one nineteenth-century lay Catholic leader explained, "the connection between a slave owner and a slave was 'more generous and touching' than that between a capitalist employer and an employee." ${ }^{590}$ The following subsection explains how the Catholic critique of the free market system or capitalism contributed to the American Church's rationalization for the continuation of slavery. Prelates and priests—influenced by the arguments of the Catholic apologist movement — condemned the free labor system as part of their denunciation of Protestantism. At the same time, clergy argued that Catholicism offered an alternative economic model that provided greater benefits to a broader portion of the general public.

588 Ibid.

${ }^{589}$ Gjerde, 244.

${ }^{590}$ Orestes A. Brownson quoted in Ibid. 
According to Catholic historian W. Jason Wallace, "[a]lmost a half a century before Max Weber proposed his now famous thesis ${ }^{591}$ Spalding suggested that Protestant values contributed to the more detrimental effects of capitalism.. ${ }^{592}$ Writing in 1855 , Spalding noted that the growth of Protestantism in the United States had created a “"degenerate age of Mammonism, enlightened in material interests and in the matter of dollars and cents." ${ }^{, 593}$ The Louisville prelate believed that Protestantism encouraged individualism, superfluous economic competition, and avarice in society because Protestants concerned themselves only with material and economic progress, rather than "true" religion. In contrast, eighteenth and nineteenth century Protestants and secularists criticized the Church as a repressive institution that produced impoverished states. According to most non-Catholics, the United States had developed, advanced, and prospered during the first half of the nineteenth century because the influence of Catholicism remained limited. However, as leader of the apologist movement, Spalding interpreted differently the effects of Catholicism in the Western World as well as the influence of Protestantism in the United States. ${ }^{594}$ Not only did Spalding defend Catholicism as a religion conducive to prosperity and progress, but he also challenged the assertions that Protestantism created advancement and wealth for all members of a particular society. For example, the bishop referred to nineteenth-century England as a:

${ }^{591}$ Max Weber, Die protestantische Ethik und der Geist des Kapitalismus [The Protestant Ethic and the Spirit of Capitalism], translated edition (London, England: Allen \& Unwin, 1905, 1930).

${ }^{592}$ Wallace, 137.

${ }^{593}$ Martin John Spalding quoted in Wallace, 138.

${ }^{594}$ Gjerde, 93-94, 234-242; Wallace, 39-70, 136-139; McGreevy, 29-37; Thomas W. Spalding, Martin John Spalding: American Churchman (Washington, DC: The Catholic University of America Press, 1973), 93-103. 
land of "boldest social contrasts" of rich and poor, of "speculators amassing enormous wealth in the manufacturing district, and a mass of wretched operatives worked almost to death," of "immense profits realized by avaricious capitalists, while the price of labor is cut down to the very starving point.",595

As one historian explained, "Spalding concluded with tongue in cheek, England's success as a nation was that, like all Protestant lands, 'she was emancipated by the reformation from the harassing thralldom of a conscience." ${ }^{\prime 596}$ In short, Spalding argued that the price paid for economic prosperity in Protestant countries encompassed a loss of morality and a "distorted ... message of Christianity.",597 "Prosperity was not," Spalding believed, "a measure of true religion. Jesus did not 'promote mere worldly comforts' but rather taught a 'sublime and supernatural system ... intended to raise mankind above this world., 598

If Protestantism distorted religion, encouraged greed, and promoted individualism, Spalding believed that the Church offered a resolution to nineteenthcentury economic problems. Spalding and other clergy argued that capitalism created extreme inequality and intense competition because the economic system lacked a central religious authority that could curtail immoderation. Conversely, Catholics sought an economic system that emphasized morality based on their religious teachings, with the Church serving as the religious authority to ensure that people acted justly. As McGreevy explained, nineteenth-century "Catholics saw moral choice and personal development as inseparable from virtues nurtured in families and churches."599 "What bothered Catholics," he explained, "was freedom as freedom to choose, diversity of

\footnotetext{
${ }^{595}$ Martin John Spalding quoted in Gjerde, 239.

596 Ibid.

${ }^{597}$ Wallace, 138.

${ }^{598}$ Martin John Spalding quoted in Ibid.

${ }^{599}$ McGreevy, 36.
} 
opinion for diversity's sake. This sort of freedom, without the virtue or character to make proper choices, was dangerous. ${ }^{, 600}$ According to Catholics, capitalism incentivized the manipulation of individuals, corrupt business practices, and fierce competition in the marketplace because such actions led to the unbridled accumulation of individual wealth. Protestantism contributed to the perceived callousness of capitalism because, according to Catholics, it had undermined the role of the Church as the teacher, promoter, and protector of morality. According to members of the American hierarchy, Protestantism spawned individualism and, by doing so, allowed each man (or woman) to determine what constituted a just, moral, or virtuous act. Without the Church serving as the central moral authority, Spalding and other prelates and priests believed that the inequality and injustice — created by a Protestantized free market economy—would only intensify and lead the country to ruin.

Rather than supporting the free market system promoted by northern Protestants, the "moral economy of the Church ... fostered a corporate ideal." ${ }^{\text {601 }}$ As one historian explained, the "Church created a harmonious and synthetic order to replace the disunited society created by Protestantism ... This worldview was relational rather than an individual one. Justice and mercy, rather than mere rights, were what motivated their Church." ${ }^{602}$ In particular, the Church's endorsement of a corporate ideal of the economy, or corporatism, influenced how clergy interpreted the debate over slavery and abolitionism during the era. Not only did prelates and priests deride abolitionists as religious fanatics and enemies of the Church, but clergy also believed that abolitionists

\footnotetext{
${ }^{600}$ Ibid.

${ }^{601}$ Gjerde, 244.

${ }^{602}$ Ibid.
} 
did not have the slaves' best interests in mind. Many clergy thought that "the 'more heart-felt' influence that bound together master and slave in a mutually dependent relationship ... accorded well with the Roman Catholic argument that Catholicism was a culture of justice and charity, as opposed to the grasping and avaricious Protestant world. ${ }^{, 603}$ Furthermore, slavery coincided with Catholic corporatism because the institution related to other hierarchical, yet mutually beneficial, relationships in society, such as the family, the school community, and, most importantly, the Church itself. In fact, Archbishop John J. Hughes of New York "celebrated the mutuality of the masterslave relationship and dreamt that it could be extended throughout human society." 604 Hughes argued that parents, employers, and other leaders needed to emulate the role of the slaveholder as the shepherd over his flock of slaves. "“[H]ow would the whole order of society begin to be renovated by the practice of primitive virtues," wrote Hughes, “"let us all endeavor to imitate the pastorship of the good Shepherd - for we are all shepherds, each in his own sphere." ${ }^{\circ 05}$ If Catholic corporatism prevailed, Hughes believed that "“every family [would] become a church, its head the high-priest and kings, protecting, guarding, and instructing those who constitute the objects of his affection as well as his authority." ${ }^{\circ 06}$ In essence, Hughes, Spalding, and other Catholics believed that slavery created a reciprocity shared by all members which overshadowed the risks posed by individuals engaging in the free market system. As one historian explained, "Roman Catholic leaders romanticized" their view of an "organic, relational world" supported by a corporate ideal of the economy, which included slavery, while

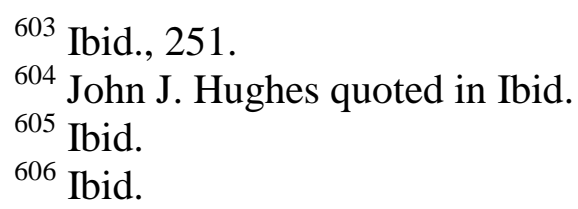


simultaneously "fret[ing] over the outcomes of wage labor in a growing capitalist society." ${ }^{607}$ However, this did not mean that clergy viewed slavery as a "positive good" that should be "proliferated indefinitely." ${ }^{608}$ Nonetheless, given the choice between the free market system promoted by northern Protestants and their corporate ideal which included a justification of slavery, the clergy viewed the second as the superior alternative because they believed that it derived from the teachings of their faith and provided greater benefits for the public good. Ultimately, the clergy's rationalization for defending slavery at the time of the Civil War derived in part from the Church's criticism of Protestantism and capitalism. In comparison to the free labor system advocated by northern Protestants, Spalding and other members of the American hierarchy believed that Catholic corporatism offered greater social stability, curtailed economic injustice, improved the moral and ethical ethos of the country, and protected the wellbeing of enslaved African Americans in the South.

Bishop Spalding, Anti-abolitionism, and the Apolitical Church, 1862-1865

By the start of the Civil War, clergy and religious orders throughout the Border States owned slaves. Archbishop Peter Richard Kenrick of St. Louis "owned several black servants," and Bishop Martin John Spalding of Louisville "inherited two or three" slaves from his father and "as bishop was legal master of twenty or more [slaves]." 609 Clergy and religious orders in the region continued to own and purchase slaves until the end of the Civil War. In July 1862, clergy at St. Thomas's Seminary in Bardstown,

\footnotetext{
${ }^{607}$ Ibid., 251-252.

${ }^{608}$ Wallace, 122.

${ }^{609}$ Heisser, 240; Spalding, Martin John Spalding, 129.
} 
Kentucky bought "a negro woman named Sara" for "sixty dollars." ${ }^{, 610}$ Furthermore, the 1860 census indicates that the Sisters of Charity, who ran the Nazareth Academy in central Kentucky, owned forty-four slaves. In fact, a year before the Civil War ended, Father John L. Verdin, president of St. Joseph's College in Bardstown, wrote Colonel James A. Hardie requesting that he "exempt, if possible, Nace \& Phil from military service" as well as the "three or four remaining colored men belonging to the Institution [Nazareth Academy].","11 The "colored men" owned by the Sisters of Charity "could scarcely be called slaves," stated Verdin. ${ }^{612}$ Instead, the priest suggested that a communal bond existed between the sisters and "Dick, Ignatius (or Nace) ... Philip (Phil)" and the other "colored men" who resided at the academy. ${ }^{613}$ Verdin indicated that the sisters treated the slaves well by providing them food, shelter, and medical care, and in return, the slaves performed essential tasks that supported the Church in the state, particularly the "education of [220] young females" at the Nazareth Academy. ${ }^{614}$ However, the war-in this case the federal policy of conscription - threatened to undermine the Catholic ministries established by the sisters, Father Verdin, and other clergy in the region.

The following subsection explores the wartime writings and correspondences of Bishop Martin John Spalding of Louisville. The subsection shows that he, like other clergy in the region, sought to maintain the status quo before the war. In particular,

${ }^{610}$ J. B. Huckley to St. Thomas's Seminary, receipt of sale, July 1, 1862, Box 6, Folder 52, CDBL, UNDA.

${ }^{611}$ John L. Verdin to James A. Hardie, October 1, 1864, Kentucky Historical Society, Frankfort, KY.

612 Ibid.

613 Ibid.

614 Ibid. 
Spalding blamed the war on radical antislavery leaders from the North, criticized the Lincoln administration for promoting wartime emancipation, and reprimanded his metropolitan—Archbishop John Baptist Purcell of Cincinnati—and other clergy for abandoning the Church's apolitical posture and endorsing abolitionism after 1862. Similar to Archbishop Peter Richard Kenrick, the Sisters of Charity, Father Verdin, and other clergy in the Border South, Spalding accepted slavery as a "legitimate human relation" that complemented his social vision for nineteenth-century America. ${ }^{615}$ Spalding's social vision derived from the teachings of his faith and conflicted with the northern Protestant or Republican design for the future of the country. Ultimately, Spalding believed that Catholicism provided a superior resolution to the debate over slavery, abolitionism, and wartime emancipation compared to Protestantism, because the Church respected the law, strove to prevent civil war, and provided for the general welfare of the entire public.

On September 22, 1862, President Abraham Lincoln issued the preliminary Emancipation Proclamation, which stated that if the Confederate states did not rejoin the Union by January 1, 1863 then all slaves remaining in areas of rebellion would become free. ${ }^{616}$ A week later, Spalding stated that the "President's Proclamation promising ... universal emancipation" had "set the country in a ferment.",617 "By calm \& considerate persons," wrote Spalding, the preliminary Emancipation Proclamation "is regarded as

${ }^{615}$ Wallace, 119.

${ }^{616}$ For more information about the preliminary Emancipation Proclamation, see: McPherson, 557-558; Eric Foner, The Fiery Trial: Abraham Lincoln and American Slavery (New York: W. W. Norton, 2010), 230-240; Louis P. Masur, Lincoln's Hundred Days: The Emancipation Proclamation and the War for the Union (Cambridge, MA: The Belknap Press of Harvard University Press, 2012), 1-138.

${ }^{617}$ Spalding Journal, CDBL, UNDA, September 29, 1862, p. 41. 
virtually, if not actually giving up the Union, \& converting the war into one of subjugation, wholesale confiscation, colonization \& extermination!"618 The Louisville prelate believed that "God alone [could] help [the nation]. Domine, Salva nos - perimus [Lord, save us - we are perishing]. ${ }^{.619}$ Three months later, Spalding opined about the executive order issued by Lincoln on January 1, 1863. "While our brethren are thus slaughtered in hecatombs,” wrote Spalding, "Ab. Lincoln cooly issues his Emancipation Proclamation, letting loose from three to four millions of half-civilized Africans to murder their Masters \& Mistresses!" ${ }^{20}$ Spalding deemed the president’s mandate an example of "Puritan hypocrisy" which had "never exhibited itself in a more horrible or detestable [manner]." ${ }^{621}$ In fact, Spalding blamed the "fratricidal butchery" on "Puritanism" or northern Protestantism, because "its preachers \& Common Schools, ha[d] at length ruined the Country," as Spalding and other clergy "foresaw and predicted." ${ }^{622}$ For the country to survive the Civil War, Spalding noted that "the eyes of America [must] be opened to its [Protestantism's] wickedness \& [must] see that their only salvation is to be found in Conservative Catholicity." ${ }^{2623}$ Exposing the perceived fallaciousness and divisiveness of Protestantism as well as underscoring the avowed integrity and unanimity of Catholicism constituted Spalding's silver lining of the "unhallowed war, thus, in God's Providence, bringing good out of evil." $" 624$ Ultimately, Spalding assumed that the Civil War would lead more Americans to join the Church

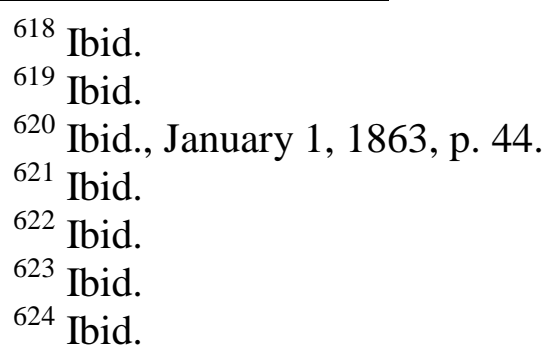


because he believed that Protestantism had created the debate over slavery and its followers had failed to resolve the dilemma, except for driving the nation to civil war.

In particular, Spalding derided Protestants because he believed they encouraged the intermixing of religion and politics, thereby creating reformist movements that disregarded law and the maintenance of social order. The prelate applauded the Church for directing its clergy to remain uninvolved in the political disputes over slavery. While Protestant ministers in the North championed the abolitionist cause and southern pastors preached proslavery sermons, the majority of Catholic prelates and priests removed themselves from the national debate, choosing instead to adhere to existing laws that recognized slavery and Church teachings that justified the institution. For example, in 1852, members of the American hierarchy convened in Baltimore, Maryland for the First Plenary Council of the United States. During the meeting, the clergy did not debate about the institution itself; instead, "they limited their remarks about slavery to the need to provide for the spiritual needs of the individual slaves." ${ }^{625}$ The clergy would not reconvene for another national conference until a year following the conclusion of the Civil War. As a result, the apolitical posture of the Church established in 1852 set a precedent that Spalding and other clergy sought to preserve. As the Louisville Guardian noted in January 1860: "not a Catholic priest of the whole country has ever been known to lend himself or to prostitute his pulpit, to the purposes of corrupt politicians. Our clergy literally know no North, no South, no East, no West ... [They] let the politicians take care of themselves." ${ }^{\prime 626}$

${ }^{625}$ Curran, Shaping American Catholicism, 102.

${ }^{626}$ Louisville Guardian, January 14, 1860 quoted in Zanca, ed., American Catholics and Slavery, 133. 
In April 1862, Spalding noted in his diocesan journal that he had written to "Cardinal [Alessandro] Barnabo" in Rome to explain his "policy of non-interference in politics." ${ }^{627}$ Two years later, while serving as the archbishop of Baltimore, Spalding explained what had been and would continue to be his "method of acting in this present storm of affairs." 628 "It is the duty of each priest and even more the duty of Bishops," wrote Spalding, "not to strive by arms but to offer our prayers before the altar ... since the church abhors bloodshed.. ${ }^{, 29}$ Although Spalding may have held private opinions about the war, the prelate vowed that he "would in no way immerse [him]self in the political agitations which came before the war and concommitent [sic] with the war." Instead, Spalding believed that he and other clergy "should stir up the souls of all towards peace and concord; and that [they] should say nothing directly concerning the political controversies in performing [their] ministry." ${ }^{, 631}$ In fact, Spalding noted that "[n]onintervention in political things always was a law to be followed by our priests and Bishops ... it is a prudent and wise law, and most fitting for our sacred duties and in accord with the most holy canons." ${ }^{632}$ In particular, Spalding supported the Church's apolitical posture or policy of non-interference because he believed that it differentiated Catholics from Protestants. "By insisting on this manner of acting [non-interference],"

${ }^{627}$ Spalding Journal, CDBL, UNDA, April 14, 1862, p. 34.

${ }^{628}$ Baltimore Journal of Martin John Spalding (transcript), Box 3, Folder 14, Archdiocese of Baltimore Collection (hereafter CABA), UNDA, December 1, 1864, p. 6. Peter E. Hogan transcribed and translated the journal from Latin and provided a copy to the University of Notre Dame Archives. The original diocesan journal is located in the Associated Archives at St. Mary's Seminary and University in Baltimore, MD. The transcript will be cited hereafter as (Spalding Journal, CABA, UNDA).

${ }^{629}$ Ibid., p. 7.

${ }^{630}$ Ibid.

${ }^{631}$ Ibid.

${ }^{632}$ Ibid. 
opined Spalding, "our priests can conciliate the minds of the dissident, and more easily persuade all sincerely inclined men that the Catholic church is not a human but a fully divine society, founded by God himself, and elevated above all human agitations. ${ }^{, 633}$ If all members of the hierarchy adhered to an apolitical posture, Spalding believed that Americans would be "able to distinguish the church of Christ [Catholicism] from human sects [Protestantism]," whose followers had been "agitated by all the human storms and by all winds of doctrine which they have thus far been found suited for." ${ }^{934}$ Instead of meddling with "the things of the earth" or temporal affairs - like northern Protestant efforts to eradicate slavery or the Lincoln administration's decision to preserve the Union by fighting the Civil War-Catholics concerned themselves with "the things of heaven" and "the divine"; thus, according to Spalding, "the Catholic Church, just like its Divine founder, [was] the same 'Yesterday, and today, and in the ages to come."

Undoubtedly, the actions of one of Spalding's suffragan bishops motivated the archbishop to compose the journal entry about the proper course of action for clergy during the war. Within the same entry, Spalding noted that he had "received letters from the city of Erie, [Pennsylvania,] written by a Catholic, in which he speaks gravely against the Bishop." 636 The layman accused Bishop Joshua [Josue] E. Young of "mix[ing] political discussions ... into his sermons," "denounc[ing] the Irish as scarcely equal to the Negroes," and "lock[ing] the doors of the church so that none of the people" could leave. ${ }^{637}$ According to historian William B. Kurtz, Young "was unique in the American
${ }^{633}$ Ibid.
${ }^{634}$ Ibid.
635 Ibid.
636 Ibid., p. 6.
637 Ibid. 
hierarchy in that he had been known to favor abolition as early as the beginning of the 1850s. ${ }^{\text {"638 }}$ Furthermore, Young denounced the Confederacy, encouraged Catholics to enlist in the Union Army, and supported the Lincoln administration during the war. ${ }^{639}$ Due to the accusations against Young, in the winter of 1864, Spalding directed a letter to Rome, "suggesting that he [Cardinal Barnabò] admonish the Bishop of Erie." ${ }^{640}$ In addition to admonishing Young, Spalding hoped that Barnabò would "likewise [reprimand] the Metropolitan of Cincinnati [John Baptist Purcell] and his Auxiliary [Bishop Sylvester Rosecrans], who ... mingle political discussions in with their religion to the great scandal of the faithful and of religion. ${ }^{, 641}$ Prior to the war, Purcell had mentored Young, and the two along with Bishop Rosecrans remained the three principal Catholic abolitionist voices among the clergy after $1862 .{ }^{642}$ Before transferring to the See of Baltimore in 1864, Spalding served as one of Purcell's suffragan bishops; however, during his years in Kentucky, the bishop of Louisville reprimanded his metropolitan and other clergy in Cincinnati for advocating emancipation and supporting the Union war effort from their pulpits and in their official diocesan newsletter, the Catholic Telegraph.

On January 11, 1862, Spalding informed Purcell that he "like[d] the change in the appearance of the Telegraph, but would have been still more pleased, if it ha[d] less of politics," noting that "[w]e have already plenty of political papers such as they are of all

\footnotetext{
${ }^{638}$ Kurtz, Excommunicated from the Union, 42.

${ }^{639}$ Ibid., 42, 98.

${ }^{640}$ Spalding Journal, CABA, UNDA, December 1, 1864, p. 6.

641 Ibid.

${ }^{642}$ Kurtz, Excommunicated from the Union, 42.
} 
complexions." ${ }^{643}$ Spalding "was particularly shocked at the little [part] . . concerning unfortunate Charleston." ${ }^{644}$ Editors of the Catholic Telegraph had "advis[ed] the Catholics to leave the doomed city, expressing their hope that the harbor would be ruined by . . blockade."645 Hoping that it had been "inserted by some irresponsible [?] writer," Spalding informed Purcell that the article had been written "in bad taste."646 Months later, Bishop Sylvester Rosecrans, Purcell's auxiliary bishop in Cincinnati, traveled to Louisville to dine with Spalding. Bishop Rosecrans invited his brother, Union General William Starke Rosecrans, ${ }^{647}$ to join the two prelates. "[A]fter having been politely toasted by me along with his brother," wrote Spalding, "[t]he General ingrossed [sic] the whole conversation ... thrusting on us the odious subject of abolition."648 In his official diocesan journal, Spalding recorded his experience at the dinner:

his Brother [Bishop Rosecrans sat] by in sullen silence. All believed it [General Rosecrans's antislavery rhetoric] to be in exceeding bad taste to say the least, marring the pleasure of a social entertainment meant $\&$ given in kindness. All must have seen that I requited the rudeness with forbearing politeness. ${ }^{649}$

By the end of the second year of the war, Archbishop Purcell, Bishop Rosecrans, and other clergy in the Archdiocese of Cincinnati had abandoned the Church's apolitical posture. The Cincinnati clergy converted the Catholic Telegraph into an antislavery periodical that advocated the Union cause and supported the Lincoln administration.

${ }^{643}$ Martin John Spalding to John Baptist Purcell, January 11, 1862, II-5-b, Archdiocese of Cincinnati Collection (hereafter CACI), UNDA.

644 Ibid.

${ }^{645}$ Ibid.

646 Ibid.

${ }^{647}$ Later during the war, Spalding referred to Rosecrans as Purcell's "favorite General." For more information, see: Martin John Spalding to John Baptist Purcell, March 22, 1864, II-5-b, CACI, UNDA.

${ }^{648}$ Spalding Journal, CDBL, UNDA, November 1, 1862, p. 42. ${ }^{649}$ Ibid. 
Purcell and Rosecrans drew the ire of Spalding, who for the duration of the war complained about the contents of the Catholic Telegraph, Purcell's pastoral letters, and other public announcements that originated in the Queen City.

A "straight out Abolition article appeared editorially in the Catholic Telegraph of last week [April 8, 1863]," reported Spalding. ${ }^{650}$ The Louisville bishop believed at first that it had been penned by Bishop Rosecrans; however, after further inquiry, he learned that Archbishop Purcell had written the article. "Is it not sad," wrote Spalding, "thus to commit the church to the abominable and almost Satanic fanaticism of its worst enemies [northern Protestants]." ${ }^{651}$ In particular, Spalding criticized Purcell for misrepresenting their faith. During Purcell's "St. Patrick's sermon," the Cincinnati prelate "stated that if St. Patrick had lived during our day he would have been called an abolitionist. ${ }^{, 652}$ In addition, Bishop Rosecrans had "designated" the "Order of Mercy ... '[t]he first antislavery society." 653 During the same month, the Catholic Telegraph published that "slavery and the Catholic Church could never get along well together." clergy charged that Spalding and other defenders of slavery had misinterpreted scripture, Catholic teachings, and the popes' statements about slavery. "Any one who can find anything in [the words of St. Paul] in favor of slavery," argued the Catholic Telegraph, "must have piercing optics." ${ }^{655}$ Furthermore, Purcell and Rosecrans claimed that Popes Pius II, Paul III, Urban VIII, and even Gregory XVI had denounced the slave trade and

${ }^{650}$ Ibid., April 12, 1863, p. 46.

${ }^{651}$ Ibid., p. 47.

${ }^{652}$ Ibid., April 17, 1863, p. 47.

${ }^{653}$ Ibid.

${ }^{654}$ Catholic Telegraph, April 8, 1863 quoted in Zanca, ed., American Catholic and Slavery, 139.

${ }^{655}$ Ibid., 140. 
the institution itself, "show[ing] that slavery in every shape, is condemned and reprobated by the Church." ${ }^{\prime 656}$ The Cincinnati clergy also attacked southern slaveholding Catholics, stating that "[r]eligion flourishes in a slave state only in proportion to its intimacy with a free state, or as it is adjacent to it." ${ }^{, 657}$ The article continued:

There are more Catholics in the Cathedral congregation of [Cincinnati] than in North and South Carolina and Georgia! There are more Catholics in one of our second-rate congregations than in the whole state of Alabama! Louisiana ought to be a Catholic state, but it has never sent a Senator or Representative to Congress who identified himself with the Catholic cause, so far as we know. The slaveowners are not zealous men of the Church in that state. ${ }^{658}$

The attacks made by Purcell and his subordinate clergy drew the attention of Spalding and Benedict [Benjamin] Joseph Webb, the former editor of the Louisville Guardian. On April 21, 1863, thirteen days after the editors of the Catholic Telegraph derided southern Catholics and charged that the Church condemned slavery, Webb published a "severe rejoinder ... in the [Louisville] Democrat." ${ }^{659}$ Although Spalding considered Webb's rebuttal to have been a "well written" and "able" editorial, the bishop wrote to assure Purcell that he "had nothing whatever to do with the composition or publication of the article, particularly as a minister of peace, opposed to all newspaper discussions which are calculated to arouse angry feelings." 660 "Whatever else may be the result of this sad war," stated Spalding, "I trust that charity among brethren will not be

${ }^{656}$ Ibid.

${ }^{657}$ Ibid., 139.

${ }^{658}$ Ibid., 139-140. In a letter to Francis Patrick Kenrick, Spalding wrote: "It is now claimed that V. Rev. E. Purcell [the archbishop's brother] wrote the article, though some still think that, as editor, he only took the responsibility ... it reflects the views of the Metropolis [Archbishop John Baptist Purcell]." For more information, see: Martin John Spalding to Francis Patrick Kenrick, April 22, 1863, 37-D-34, AAB.

${ }^{659}$ Spalding Journal, CDBL, UNDA, April 21, 1863, p. 47. ${ }^{660}$ Ibid. 
thereby weakened." ${ }^{661}$ Although Spalding assured Purcell that he had nothing to do with the publication, the Louisville prelate undoubtedly agreed with the contents of Webb's article. To Spalding and other clergy in the Border States, Purcell and Rosecrans had abandoned the Church's apolitical posture, distorted Catholic teachings, condemned coreligionists, and joined those who denounced their faith in a reformist movement that perpetuated the war and threatened national stability. In short, by the spring of 1863 , Purcell, Rosecrans, and the other prelates and priests in Cincinnati had become synonymous with those whom Spalding derided most: abolitionists, Protestants, and Republicans. Nonetheless, the prelates shared the same faith, a bond which Spalding sought to preserve; he did not want the American Church to suffer from the same infighting that sundered the mainstream Protestant denominations. In fact, Spalding utilized their shared Catholicism as a way of combatting the Cincinnati clergy's abolitionist efforts. Spalding appealed to the Roman hierarchy to censure Purcell.

On October 23, 1863, Spalding recorded in his diocesan journal that he had “[r]eceived a letter of Card'1 Barnabo," which included a "Report on his dissertation"; the Roman official deemed it "Very satisfactory." ${ }^{662}$ For four straight days in October 1863, the Osservatore Romano — a Vatican periodical—published a serialized manuscript titled "Considerations of a Kentucky Catholic on the American Civil War." 663 Commonly referred to as Spalding's "Dissertation on the American Civil War," the four-part manuscript sought to provide a "correct idea of our Civil War" for Catholic officials in

\footnotetext{
UNDA. ${ }^{662}$ Spalding Journal, CDBL, UNDA, October 23, 1863, p. 51.

${ }^{663}$ David Spalding, ed., "Martin John Spalding's 'Dissertation on the American Civil War,"” The Catholic Historical Review 52 (April 1966): 68.
}

${ }^{661}$ Martin John Spalding to John Baptist Purcell, April 21, 1863, II-5-b, CACI, 
Rome. $^{664}$ In an April 1863 letter to Archbishop Francis Patrick Kenrick, Spalding first mentioned his plans to write the dissertation. Within a month, Spalding had finished the work and informed Barnabò — the "Cardinal Prefect of the Congregation of

Propaganda" - that he would "send it from New York and without date or name, affixing as signature only this_-Alumnus of the S[acred] C[ongregation], "' so as to not

“"compromise [him]self with our Government." "665 Historian David Spalding noted that the dissertation offered the Louisville prelate, who had maintained and promoted "strict neutrality" within the Church, the "opportunity to unburden himself of deep-felt and long-suppressed sentiments." ${ }^{\text {,66 }}$ Furthermore, the dissertation demonstrated the prelate's concern "over the avowed partisanship of" Purcell, Rosecrans, and other Ohio clergy, who had "transformed the Cincinnati Catholic Telegraph into a political journal advocating the immediate eradication of slavery." ${ }^{, 667}$

The first part of Spalding's dissertation addressed "The History and Peculiar Character of Our Government," in which the prelate defended secession. ${ }^{668}$ "[T]he peculiar character of our government resting, as everyone admits, on the consent of the governed," noted Spalding, "clearly concedes to the contracting parties the right of undoing freely what it has freely done." ${ }^{, 69}$ Spalding applauded the South because its people "ha[d] always been much more conservative and anti-revolutionary than the North," whose leaders had "been among the loudest patrons and advocates of each miserable European revolution, and the most devoted friends of Kossuth, Garibaldi, and
${ }^{664}$ Ibid., 70.
665 Ibid., 66.
666 Ibid., 67.
667 Ibid.
668 Ibid., 70.
${ }^{669}$ Ibid., 73. 
nearly every other wicked charlatan of our times.."670 The second part addressed "The Principal Causes of the War," underscoring "The Commercial Tariff with Foreign Nations" as the primary reason and "African Slavery" as the secondary cause. ${ }^{671}$ Explaining how the economic "interests of the North and the South ha[d] always been antagonistic," Spalding claimed that northerners had become obsessed with the revenues earned from their manufacturing-based economy. ${ }^{672}$ According to Spalding, the war had erupted because the circumstances had "clearly turned to the profit of the North to increase as much as possible the tariff" as a way of "increase[ing] the price of their own products." 673 As Spalding rightly alluded, the "controversy" over the tariff "ha[d] been fiercely agitated in the national Congress" for more than half a century, in which the "inhabitants of the South ha[d] always accused those of the North of wanting to get rich at their expense." 674 Thus, the war began because "the evil" had become "so great" that southerners could "no longer . . . tolerate it.",675

Regarding slavery, Spalding considered it "a great social evil left to us, as a sad heritage by Protestant England"; however, the bishop refused to support an immediate end to the institution because he believed that such a plan would "[ruin] the country and [cause] injury to the poor slaves themselves." "W76 "What can be done to free them in such a way as not to worsen their sad condition?" asked Spalding; "This is the real problem for

${ }^{670}$ Ibid.

${ }^{671}$ Ibid., 74-76.

${ }^{672}$ Ibid., 75 .

${ }^{673}$ Ibid.

${ }^{674}$ Ibid.

${ }^{675}$ Ibid. Historian W. Jason Wallace argued that Spalding's decision to identify the commercial tariff as the primary cause of the war reflected the prelate's criticism of capitalism. For more information, see: Wallace, 137-139.

${ }^{676}$ Spalding, ed., "Martin John Spalding's 'Dissertation on the American Civil War," 76. 
which a wise and practical solution is very difficult." ${ }^{, 677}$ Spalding trusted the Church to devise the most advantageous solution to the issue of American slavery. "If all of useven the majority-were Catholics," wrote Spalding, "the solution would be less difficult; because then the Catholic religion ... would first be able gradually to better [the slaves'] condition, instructing them in their Christian duties and at the same time inclining the hearts of their masters to compassion."678 Spalding believed that a gradual emancipation plan provided greater securities for the slaves themselves as well as kept Catholic slaves within the Church. "Our experience and observation shows us the evidence that those who are in such a way liberated ordinarily become miserable vagabonds, drunkards, and thieves," explained Spalding. ${ }^{679}$ African Americans in the North- "where so much noise is made by the fanatic preachers against the great sin of slavery" - "form[ed] a class inferior and set apart, like the lepers of the gospel," argued Spalding, "they are poor, unhealthy, and miserable, and they die by the thousands ... without the consolation of religion." ${ }^{, 60}$ Furthermore, Spalding noted that "[a]lmost all the Catholics who are Negroes are found in the states of the South, and those who are emancipated and go to the states of the North become almost all, at least their children, within a short time Protestants, or else indifferent and infidel." ${ }^{\text {,61 }}$ Above all, Spalding indicated that the "Constitution clearly recognize[d] and even protect[ed] slavery.",682 The bishop derided those "Protestant preachers" who "denounce[d] —almost every Sunday — slavery as the greatest and most atrocious sin of all, without any
677 Ibid.
${ }^{678}$ Ibid.
${ }^{679}$ Ibid., 77.
680 Ibid.
681 Ibid.
${ }^{682}$ Ibid., 78. 
qualification."683 Blaming Protestant preachers for the plight of African Americans, secession, and the war, Spalding wrote:

As happens in almost all Protestant movements, there was in their way of acting none of that wise moderation which looks in the face all the practical difficulties of the situation and strives to adapt the means to the end; and so with their overhaste and violence they bring evil to the cause which they tried to promote with a vehemence so ill-judged. Some of these blind fanatics openly proposed their program of modern progress as embracing two principal points: namely "the violent destruction of those two relics of a barbarous age - slavery and Catholicism!!"684

In the third section, Spalding contrasted "The [Original] Goal proposed by the Government in the War" with how the Lincoln administration changed the course of the conflict after January 1863. "In the beginning of the war," explained Spalding, "the aim advanced by the government was, to restore the old Union, after defeating the rebels, assuring all of them thus, if they returned to obedience, their political rights intact under the Constitution." 685 Spalding informed his readers that a "solemn act of the national Congress, promulgated almost by a unanimity of votes, expressly declared this to be the only aim of the war." 686 Nonetheless, the prelate believed that Lincoln had disregarded the original objective of the war and had converted the conflict into an emancipation crusade that would devolve into race war in the South. According to the bishop, Lincoln's Emancipation Proclamation "free[d] more than three million Negroes, inviting them ... to begin slave uprisings, and to massacre the whites - men, women, and children - in the manner of the horrible massacre of the whites by the Negroes on the
${ }^{683}$ Ibid.
684 Ibid., 79
685 Ibid., 80
${ }^{686}$ Ibid. 
island of Santo Domingo."687 Spalding also accused the federal government of forcing freedmen into military service in the Union Army. "[V]ery few of the Negroes wanted to become soldiers," wrote Spalding, "and the greater part of this small number ${ }^{688}$ even had to be forced to take up arms, of which many also ran away from the militia, if they could."689 Overall, Spalding argued, the Lincoln administration had freed the slaves and authorized their enrollment in the Union Army to accomplish solely Republican objectives - presumably the expansion of the free labor system —at the expense of the slaves themselves. For example, Spalding claimed that "the abolitionists are not the true and solid friends of the Negroes, as they call themselves, but rather their enemies, who make use of their miserable state to promote their own interests."690

The final section of Spalding's dissertation explained how the war had impacted "the Catholic Religion" and underscored the proper "Duty of our Bishops and Priests in the Present Circumstances." ${ }^{\circ 91}$ Spalding reemphasized the apolitical posture adopted by the American Church at the start of the war. Despite the Catholic policy of nonalignment, Spalding claimed that the federal government had infringed on the religious liberties of the Church by encouraging the enlistment of immigrant Catholics and by forcing clergy to display flags and patriotic banners from their churches. The bishop noted that most northern clergy accommodated the federal government's requests because they "considered it to be inexpedient even to seem to oppose the government,"

687 Ibid.

${ }^{688}$ Spalding approximated that between "two to three thousand Negroes" had been authorized for military service. For more information, see: Ibid., 81.

689 Ibid.

${ }^{690}$ Ibid.

${ }^{691}$ Ibid., 82. 
while other prelates and priests "held themselves apart and neutral."692 In fact, Spalding claimed that "excepting two or three — among whom is found my Metropolitan — our archbishops and bishops limit themselves now to the spiritual and to prayers."693 Indeed, Spalding's fourth section of his dissertation constituted a direct attack against Purcell and the other clergy in Cincinnati who had deviated from the Church's policy of nonalignment. Spalding's dissertation exposed the clergy's political activities as a way of encouraging the Vatican to take action against Purcell and his subordinates. In addition to Purcell, the "two or three" Spalding mentioned probably referenced the archbishop's brother, Bishop Rosecrans, and Bishop Young of Erie, Purcell's pupil and fellow abolitionist. ${ }^{694}$ Spalding considered the Church's policy of neutrality to be "the most prudent and wise rule to be followed in our present circumstances" because it differentiated Catholics from Protestants. ${ }^{695}$ If clergy engaged in political partisanship, the "Holy Church would lose thus the prestige, which it now enjoys, of divineness in the estimation of the public, and it would sink immediately to the low level of the purely human Protestant sects. ${ }^{\circ 66}$ Instead, the Louisville bishop hoped that the Church would keep "itself resolutely, as in the past, apart from men, and all for God, for peace, for fraternal love, it will remain after the war in a favorable position in the eyes of all, and it

692 Ibid., 83.

693 Ibid.

${ }^{694}$ Ibid. Historian David Spalding noted that the "reference to Archbishop Purcell was omitted in the Osservatore Romano." However, letters in the Vatican Archives indicate that Cardinal Barnabò and Pope Pius IX read the dissertation before it was published; therefore, the pope and his Roman officials would have read the reference to Purcell and the other politically-active clergy. For more information, see: Ibid., 67-68, $83 n 31$.

$$
\begin{aligned}
& { }^{695} \text { Ibid., } 83 . \\
& { }^{696} \text { Ibid., } 84 .
\end{aligned}
$$


will be able to do immense good and make marvelous progress" in both the North and the South. ${ }^{697}$ Spalding aspired for all Americans to say:

Here is a true Church of God, which has in no way become involved in all this Protestant fanaticism and with the shedding of all this fraternal blood! Its hands are pure; they do not drip blood like those of our Protestant ministers! ${ }^{698}$

Historian David Spalding concluded that "[i]t is difficult to determine the extent of the [dissertation's] influence." ${ }^{, 99}$ Letters in the Vatican Archives reveal that both Barnabò and Pope Pius IX read Spalding's dissertation and received it "graciously" and "with great interest."700 Less than a month after the dissertation appeared in Osservatore Romano, Purcell received a letter from Pope Pius IX, urging the Cincinnati prelate "to unite his efforts [with] those of his fellow bishops [particularly the archbishop of New Orleans] to bring about the cessation of the internecine war." 701 However, neither the pope's letter nor Spalding's dissertation convinced the Cincinnati clergy to abandon their abolitionist efforts. In the summer of 1863, while waiting for a response from Rome regarding his dissertation, Spalding recorded in his diocesan journal that "The Catholic Telegraph still keeps up its abolition articles, to the great injury, I think, of Religion ... The true policy of the Church in this crisis is non-intervention in politics, as it has ever been." ${ }^{, 702}$ In December 1863, a month after Purcell received the dispatch from Pius IX, Spalding penned a scathing letter to his metropolitan. "Of the two Metropolitans to whom the Apostolic letter [Pius IX's letter] was expressly addressed," Spalding believed that "one [Purcell] contented himself" to "publishing it, without comment, in the

${ }^{697}$ Ibid.
${ }^{698}$ Ibid.
${ }^{699}$ Ibid., 68.
${ }^{700}$ Ibid.
${ }^{701}$ Ibid.
${ }^{702}$ Spalding Journal, CDBL, UNDA, June ??, 1863, p. 48. 
newspapers, where it became an object of bigoted \& silly censure by a portion of our runmad secular press."703 Conversely, "the sainted [Archbishop Jean-Marie] Odin, attended to its letter \& its spirit in a manner becoming a Christian Bishop, without trenching on partisan or political ground." ${ }^{, 704}$ Of the two responses, Spalding believed the latter proved "the best model for action," because Odin's pastoral "was wholly free from political allusion."705 Writing with "Christian \& fraternal frankness," Spalding informed Purcell that his pastoral letter had not "compl[ied] with the well known wishes of our Venerable Supreme Pontiff.,"706 Included under the title "Our Country $-\underline{\text { Invocation for Peace" - }}$ the premise of Pope Pius IX's letter to the American archbishops-Purcell advocated the Union cause, which Spalding “considered wholly unexceptionable [unacceptable]."707 Furthermore, Spalding suggested that the " 3 rd [paragraph] in so far as it alludes to slavery .. might be omitted . . in no case should any political sentiment be expressed." ${ }^{, 708}$ In fact, Spalding noted that "[i]t would be very simple \& easy to remove all suspicion of political bias, by saying explicitly, that the Peace which we invoke, [is] in accordance with the clearly expressed wishes of the Holy Father."709 Despite Spalding's recommendations and in direct opposition to his sentiments, Purcell published his official Lenten pastoral letter in January 1864. In his diocesan journal, Spalding complained that Purcell had "take[n] open ground in favor of Abolition with its accompanying

${ }^{703}$ Martin John Spalding to John Baptist Purcell, December 19, 1863, II-5-b, CACI, UNDA.

${ }^{704}$ Ibid.
${ }^{705}$ Ibid.
${ }^{706}$ Ibid.
${ }^{707}$ Ibid.
${ }^{708}$ Ibid.
${ }^{709}$ Ibid.


Programme [sic]. ${ }^{, 710}$ In utter defiance of what Spalding and other Border State clergy believed, Purcell declared the following in his pastoral: "“while we go, with our whole heart and soul, for the maintenance of the Union and Abolition of slavery - against

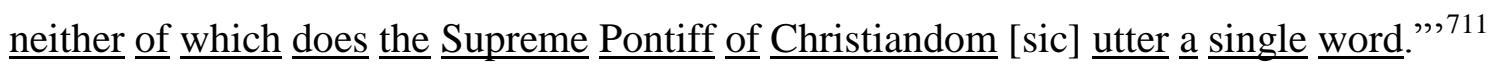

Ten months later, Purcell wrote the following to President Abraham Lincoln:

I am going to vote for you [in the presidential election], so is my Auxiliary Bishop, Rosecrans; my brother \& all of our oldest priests in my family are all going to vote for you also - So do, good Mr. President, grant me this favor and let me feel that we have a President who has some little regard for the Old Archbishop of Cincinnati. ${ }^{712}$

Thus, Spalding's efforts at maintaining an apolitical Church failed in regards to his metropolitan. From late-1862 until the end of the war, Purcell and other clergy in the Archdiocese of Cincinnati, as well as Bishop Young of Erie, championed abolitionism, advocated the Union war effort, and supported the Lincoln administration. Spalding derided their efforts because he believed that they distorted Church teachings, disregarded the sentiments of the Vatican hierarchy, and perpetuated civil war. The bishop's dissertation demonstrated that he blamed the war on northern Protestant preachers who taught that slavery constituted an evil condemned by God. Spalding felt that, by advocating abolitionism, Purcell and his subordinates joined ranks with those who also denounced Catholicism. Overall, Spalding sought to discern the Church from Protestant denominations by promoting a plan for gradual emancipation and arguing that Catholics could resolve the dispute over slavery peacefully and justly.

${ }^{710}$ Spalding Journal, CDBL, UNDA, January 24, 1864, p. 54.

${ }_{711}^{711}$ John Baptist Purcell quoted in Ibid.

${ }^{712}$ John Baptist Purcell to Abraham Lincoln (transcribed copy of the original), October 18, 1864, II-5-b, CACI, UNDA. The original letter is located in the Lincoln Manuscripts at the Library of Congress in Washington, DC 


\section{The Second Plenary Council of 1866}

"“[F]our million of these unfortunate beings are thrown on our charity,", exclaimed Spalding, "“and they silently but eloquently appeal to us to help. We have a gold opportunity to reap a harvest of souls, which neglected, may not return.",713 In October 1866, at the Second Plenary Council in Baltimore, Spalding appealed to fellow prelates to devise a plan for the care and ministry of former slaves in the South. By that time, Spalding had been transferred to the See of Baltimore following the death of Francis Patrick Kenrick. A member of the southern hierarchy and a slaveholder himself, Spalding proposed that a special office of the Church be created to both convert freedmen and freedwomen to Catholicism and to assist in their transition out of slavery. Despite Spalding's efforts, the members of the council rejected the archbishop's plan. In fact, only one of the several chapters included in the Decrees of the Council mentioned the "Spiritual Care of Negroes."714 In the section on "The Emancipated Slave," the clergy stated that they hoped "a more gradual system of emancipation could have been adopted, so that [the former slaves] might have been in some measure prepared to make a better use of their freedom, than they are likely to do now."715 Furthermore, the council members wanted "to extend to them that Christian education and moral restraint which they so much stand in need of.", 716 According to historian William B. Kurtz, "[i]n the end, the council's appeal had no real effect in promoting Catholic relief or missionary

${ }^{713}$ Martin John Spalding quoted in quoted in Zanca, ed., American Catholics and Slavery, 255.

\footnotetext{
714 Ibid., 256

715 Ibid.

716 Ibid.
} 
efforts on behalf of African Americans in the nineteenth century." ${ }^{, 717}$ Furthermore, Kurtz argued that "[a]t the close of the war, the church made little effort on behalf of African Americans in terms of humanitarian relief or evangelization," an outcome that "perfectly mirrored most Catholic leaders' opposition to emancipation during the war itself.,"718 Kurtz portrayed the Church and American Catholics in general as apathetic toward the plight of African Americans, both enslaved and free. In short, Kurtz argued that the majority of Catholics cared little about blacks before, during, and after the war, because they supported slavery until 1865 and failed to create a plan for the care of freedmen and freedwomen during Reconstruction. The following subsection analyzes the role that clergy played in the humanitarian and missionary efforts for slaves during the war as well as explains why Spalding's plan at the Second Plenary Council failed in 1866. Overall, the subsection argues that the clergy did not abandon southern blacks because they disparaged the group. Rather, the clergy lacked the necessary resources-religious personnel and revenue - to care for both African Americans in the South and the growing immigrant Catholic population in the North.

Although many lay Catholics—particularly the Irish—viewed African Americans with disdain both during and after the war, members of the southern hierarchy tried to improve the conditions of slaves and freed blacks. ${ }^{719}$ "[Bishop William H.] Elder is most

${ }^{717}$ Kurtz, Excommunicated from the Union, 107.

${ }^{718}$ Ibid., 106-107.

${ }^{719}$ Mark A. Noll wrote: “[t]ragically, especially lower-class Catholics, often Irish, who were economic competitors with liberated slaves, found themselves pulled along when the Democratic party after the Civil War allied itself with the Ku Klux Klan and other racist movements to strip blacks of their newly won civil rights. In these circumstances, it was a short step for some Catholics to move from a religiously based ideological antiabolitionism to a racially grounded opposition to African American civil 
anxious to obtain sisters and funds from the Northern Government for Negro orphan children's support, at Vicksburg - and priests to instruct and receive into the Church adult Negroes," wrote Archbishop Purcell. ${ }^{720}$ During the summer of 1863, Elder, the bishop of Natchez, Mississippi, answered the call of Dr. Henry S. Hewit to provide clergy for African Americans who had been affected and displaced by the Battle of Vicksburg. Along with other clergy from his diocese, Elder worked in hospitals near the city and ministered to blacks. However, by the fall of 1863, Elder determined that he and his clergy could no longer care for the displaced slaves alone. Elder first contacted Purcell, who relayed his request to Spalding and Archbishop Peter Richard Kenrick of St. Louis. ${ }^{721}$ On October 22, 1863, Spalding indicated that he had received the letter from Purcell, mentioning "the poor blacks ... [who were] dying frightfully at Vicksburg \& Natchez.",722 "I feel a lively sympathy for [the displaced slaves], but after every effort, I fear I shall scarcely be able to do anything, or much in this direction," explained Spalding. ${ }^{723}$ The Louisville bishop doubted that he would be "able to find priests or religious who are able or willing to go, $\&$ at the same time suitable., ${ }^{, 724}$ Throughout the war, Spalding struggled to obtain enough chaplains and women religious to aid soldiers

rights." For more information, see: Mark Noll, review of Wahrheit, Einheit, Ordnung, $835-836$.

${ }^{720}$ John Baptist Purcell to Jean-Marie Odin, October 16, 1863, VI-2-g-13, Archdiocese of New Orleans Collection (hereafter CANO), UNDA.

${ }^{721}$ Ibid.; Kurtz, Excommunicated from the Union, 104-105.

${ }^{722}$ Martin John Spalding to Jean-Marie Odin, October 22, 1863, VI-2-g-13, CANO, UNDA.

${ }_{723}$ Ibid.

${ }^{724}$ Ibid. 
in Kentucky, so he probably did not have available clergy to send to Mississippi. ${ }^{725}$

Although Spalding's failure to support Elder proved sincere, the prelate noted that the "Metropolitan of St Louis [Peter Richard Kenrick], \& many others think that those who have sympathized \& encouraged the causes which have led to this frightful result, should consider it their duty to volunteer to aid in repairing the mischief."726 "This, of course," remarked Spalding, "refers to our brethren of Cincinnati." 727 According to Spalding, Kenrick and other clergy charged that Purcell, Rosecrans, and "those who wr[ote] for the Telegraph"" should bear the burden of caring for displaced slave because they advocated abolitionism and supported the Union war effort. ${ }^{728}$

Although some of the clergy disparagingly suggested that Purcell and his subordinates should alone deal with the situation they created, other prelates and priests continued to show their support for African Americans both during and after the war. For example, once Spalding became archbishop of Baltimore, he allocated " $\$ 3,000$ ” in a "trust . . . for the building of a chapel for the Negroes" in the nation's capital. ${ }^{729}$ In December 1864, Spalding indicated that "another church for the Negroes" would be "erected in Washington," bringing the total to "three new chapels [to] be opened in the Capital city next year [1865]."730 Spalding worked with members of the Washington, D.C. community to construct churches and other religious institutions for black Catholics

${ }^{725}$ For example entries from his official diocesan journal that describe the bishop's efforts to allocate chaplains and women religious during the war, see: Spalding Journal, CDBL, UNDA, p. 19-24, 41.

${ }^{726}$ Martin John Spalding to Jean-Marie Odin, October 22, 1863, VI-2-g-13, CANO, UNDA. ${ }^{727}$ Ibid.

${ }^{728}$ Bishop James Wood of Philadelphia, PA quoted in Kurtz, Excommunicated from the Union, 105.

${ }^{729}$ Spalding Journal, CABA, UNDA, October 21, 1864, p. 4.

${ }^{730}$ Ibid., December 20, 1864, p. 8-9. 
in the city. The writings in his journal indicate that he relished the opportunity to support the religious life of African Americans, a group which he considered an important aspect of his archdiocese. Furthermore, the prelate's August 1865 circular shows that he intended to extend these efforts throughout the Deep South during the Reconstruction period. "The cry of distress which comes to us from all parts of the South should ex[c]ite our sympathy and stimulate our charity," proclaimed Spalding. ${ }^{731}$ The archbishop "commanded a collection for the afflicted in the southern parts of the states," where "the populations [we]re reported to be threatened with nothing short of downright starvation." ${ }^{, 732}$ Considering the "affliction ... far too gigantic in its proportions to be adequately relieved by individual contributions," Spalding made the following plea to his Baltimore flock:

Can we be held blameless before God, if our brethren, whom we are solemnly commanded to love even as ourselves, should perish through our coldness and neglect? Most of the sufferers are women, children, and other non-combatants, whose hands are outstretched to us imploring succor, and whose sighs of anguish ascend to heaven, while their tears bedew the earth. Can we find it in our hearts to resist their appeal? We think not. ${ }^{733}$

Undoubtedly, many of those whom Spalding referred to and sought to aid were former slaves. Knowing that weekly collections would not suffice for the humanitarian relief and ministry of African Americans in the South, the archbishop joined fellow southern prelates - particularly Bishop Augustin Verot - and appealed to the members of the Second Plenary Council to devise a formalized plan of aid. ${ }^{734}$

\footnotetext{
${ }^{731}$ Ibid., September 2, 1865, p. 21.

${ }^{732}$ Ibid.

733 Ibid.

${ }^{734}$ Curran, Shaping American Catholicism, 109.
} 
Although the members of the council rejected the southern prelates' proposal, they "urge $[\mathrm{d}]$. . . the clergy and people of our charge the most generous cooperation with the plans which may be adopted by the bishops of the dioceses in which [the former slaves] are." ${ }^{735}$ Rather than supporting a centralized plan, the clergy delegated the responsibility to each diocesan leader. "Our only regret in regard to this matter," explained the council members, "is, that our means and opportunity of spreading over them the protecting and salutary influences of our holy religion, are so restricted."736 Ultimately, the council members determined that they did not possess the "means"personnel or revenue — required to oversee and support "Spalding's proposal to create a special office to aid local bishops in finding missionaries to work with the former slaves and to help raise funds for that ministry." ${ }^{, 737}$ Thus, the failure to provide for African Americans at the end of the war mirrored the clergy's inability to allocate the religiouspriests and sisters - to assist Bishop Elder during the war. As Catholic historian John Tracy Ellis explained, the "Church in no way escaped the strain of a war that told so heavily on the personnel and resources of every institution in the land."738 Regarding the plan proposed by Spalding at the Second Plenary Council, Ellis noted that "it was far easier to exhort than to win effective action."739 Furthermore, following the war, some religious orders tried to provide care and religious instruction to African Americans in the South, only to be castigated and threatened by the white majority. Although some clergy shared the same racial prejudices as other white southerners, many prelates, priests, and

\footnotetext{
${ }^{735}$ Zanca, ed., American Catholics and Slavery, 256.

${ }^{736}$ Ibid., 256-257.

${ }^{737}$ Ibid., 256.

${ }^{738}$ Ellis, 100.

739 Ibid., 101.
} 
women religious decided to abandon their ministry to blacks for fear of alienating the white Catholic laity or provoking white Protestants. Ellis concluded that "through a combination of racial prejudice, timidity, and scarcity of manpower and resources, the chance for large-scale conversion" of African Americans "after the Civil War gradually slipped away ... And yet it would be a mistake to infer that the Church had done nothing in this regard. ${ }^{, 740}$ In addition, Ellis placed the Church's failed efforts to evangelize African Americans within the context of the growing immigrant Church in the North. As he explained, the Church's relationship with African Americans:

can be properly understood only in the light of the spiraling Catholic immigration ... Because of their religious faith these newcomers became the direct responsibility of the Church, a responsibility that taxed every bit of manpower and money in the parishes. These were the years - roughly from 1870-1900which fixed the American Catholic pattern as predominantly an urban one with the immigration settling for the most part in the large industrial centers.

Following the war, the American hierarchy decided to invest their resources into caring for the growing population of baptized Catholics in the North rather than devoting the personnel and revenue to a missionary effort that might fail in the South. As the Catholic population grew in the North and Midwest during the nineteenth century, the American Church's southern roots gave way to the pull of concerns for immigrant Catholics located in states north of the Ohio River. ${ }^{741}$ By 1866 , the northern hierarchy dominated the American Church; therefore, their interests rather than those of the southern clergy received the attention of the Second Plenary Council. Nevertheless, the southern clergy did not cease efforts to provide for former slaves. As Ellis explained, "the southern bishops tried again and again by appeals for workers and funds" to minister to African

${ }^{740}$ Ibid., 102.

${ }^{741}$ For a work that analyzes the shift in leadership of the American Church from Maryland to New York, see: Curran, Shaping American Catholicism, (2012). 
Americans. ${ }^{742}$ In the end, the Church's failed plans to provide humanitarian relief and religious education to former slavers derived not from a lack of compassion for African Americans but from a lack of resources and the changing composition of the American Church during the nineteenth century.

\section{Conclusion}

Overall, the chapter argued that Border State clergy offered an alternative voice in the debate over slavery, abolitionism, and wartime emancipation. Due to the Vatican's prolonged silence on the issue, American clergy turned to works like Kenrick's

Theologia moralis, which justified slavery based on Catholic teachings and Church history. Most importantly, Kenrick's moral theology argued that Catholics should adhere to all state and national laws in order to preserve order and stability in society. Several scholars have demonstrated how economics, racism, concerns about immigrant Catholics, and political partisanship shaped the Church's defense of the institution. Although these factors influenced some Catholics, this chapter underscored how the clergy's faith and their shared religious principles proved the more significant factors regarding their rationalization of human bondage. In particular, the rise of devotional Catholicism and its emphasis on personal suffering as a pious experience colored the clergy's interpretations of slavery. Moreover, the Catholic apologist movement or antiProtestantism influenced the clergy's justification of slavery. Prelates and priests derided the free market system promoted by most northern Protestants because they believed that it remained unjust and immoral. By denouncing capitalism as a system that created too much individualism and avarice, clergy argued that the slaves' best interests remained in

\footnotetext{
${ }^{742}$ Ibid.
} 
bondage in the South. Clergy viewed slavery as synonymous with their corporate ideal of the economy, which they believed offered greater protections for the public good. Furthermore, most prelates and priests rejected liberal reform movements, such as abolitionism, and vowed to uphold the law so as to preserve order and stability in society. In particular, Spalding defended slavery by criticizing northern Protestants, whom the prelate blamed for the national crisis, the secession movement, the war, and the plight of African Americans. The Louisville prelate argued that the Church offered an alternative resolution — specifically a plan for gradual emancipation — that would have prevented civil war. Following the war, clergy continued to adhere to national law by accepting the passage of the Thirteenth Amendment. In fact, many of the southern clergy who formerly held blacks in bondage appealed to the American Church to devise a plan to minister to freedmen and freedwomen as well as assist in their transition out of slavery. Although the majority of clergy rejected the plan, its failure should not be interpreted as widespread Catholic disdain for African Americans. On the contrary, the plan's failure reflected the changing composition of the American Church, as resources, the lay population, and ecclesiastical power became concentrated in the urban North. 


\section{CHAPTER V}

\section{THE “OBVIOUS INFRINGEMENT OF RELIGIOUS LIBERTY”: ROMAN CATHOLIC UNDERSTANDINGS OF THE SEPARATION OF CHURCH AND STATE IN THE CIVIL WAR BORDER SOUTH ${ }^{73}$}

In March 1866, counsel for the state of Missouri and attorneys representing Father John A. Cummings, Roman Catholic priest from the Archdiocese of St. Louis, presented their arguments before the Supreme Court of the United States in the case of Cummings v. Missouri. Six months earlier, the Missouri Supreme Court had upheld the test oath required for all practicing clergy in the state, a law that Cummings refused to obey. The nation's highest court, however, ruled the test oath unconstitutional, stating that the "the oath requirement was ex post facto" and that "Missouri's constitution violated federal safeguards." ${ }^{744}$ To Father Cummings and other Catholic clergy, the ruling in Cummings v. Missouri represented a triumph for religious liberty. Border State prelates and priests considered required loyalty oaths, the confiscation and destruction of Church property, and forced conscription of clergy in their diocese to be actions that violated the separation of church and state, a concept the clergy valued for the protection of their religion in a Protestant-dominated society. Because Catholic clergy viewed the Civil War through a religious lens, actions or policies that pushed the limits of the separation of church and

${ }^{743}$ The Baltimore Catholic Mirror (September 9, 1865) quoted in Judith Conrad Wimmer, "American Catholic Interpretations of the Civil War," PhD dissertation, Drew University, 1979, 318.

${ }^{744}$ Harold Melvin Hyman, Era of the Oath: Northern Loyalty Tests during the Civil War and Reconstruction (Philadelphia: University of Pennsylvania Press, 1954), 112. 
state during the war were resisted by Church officials. Thus, clergy in the Archdioceses of St. Louis and Baltimore and the Diocese of Louisville opposed many of the actions or policies enacted by their local state governments, the Lincoln administration, and the Union war effort because they considered them " the obvious infringement of religious liberty.",

Border State Catholic opposition to loyalty oaths should not be interpreted as having constituted a political alliance with either the northern Copperheads-Peace Democrats - or the Confederacy. ${ }^{746}$ Although much of the Catholic opposition aligned with the anti-Lincoln or anti-Republican invectives authored by leading Copperheads and Confederate politicians, Church clergy attacked the civil liberties issues foremost from a religious perspective, arguing that the actions or policies violated religious freedom or infringed on the separation of church and state. Nonetheless, most of the secondary literature available to scholars about Civil War-era opposition has focused on Protestant Americans or the immigrant Catholic laity, the majority of whom joined the Democratic Party and resided in the North or Midwest. ${ }^{747}$ More recently, Timothy Wesley's The

745 The Baltimore Catholic Mirror (September 9, 1865) quoted in Wimmer, 318.

${ }^{746}$ Undoubtedly, many Catholics supported the Copperhead movement and the Confederacy during the Civil War; however, this chapter focuses on how religion influenced Catholic opposition rather than identifying members of the Church by political or military affiliations.

${ }^{747}$ Frank L. Klement, The Copperheads in the Middle West (Chicago: University of Chicago Press, 1960); Frank L. Klement, The Limits of Dissent: Clement L. Vallandigham and the Civil War (Lexington: The University Press of Kentucky, 1970); Mark E. Neely, Jr., The Fate of Liberty: Abraham Lincoln and Civil Liberties (New York: Oxford University Press, 1991); Frank L. Klement, "Catholics as Copperheads during the Civil War," The Catholic Historical Review 80 (January 1994): 36-57; Jennifer L. Weber, Copperheads: The Rise and Fall of Lincoln's Opponents in the North (New York: Oxford University Press, 2006); William A. Blair, With Malice Toward Some: Treason and Loyalty in the Civil War Era (Chapel Hill: The University of North Carolina Press, 2014). 
Politics of Faith during the Civil War examined the role of political ministers-both Catholic and Protestant—and demonstrated how the conflict created a conundrum for clergy who subscribed to apolitical preaching. Pastors and priests who endorsed neutrality often drew the attention of the Union Army. This remained a problem throughout the war in the Border States, where loyalties were divided and anyone who did not proclaim support for the Union was often perceived to be a Confederate sympathizer. ${ }^{748}$ In addition to Wesley, Marcus J. McArthur's recent dissertation about clergy in Civil War-era Missouri underscored the issues that prevented a strict adherence to the separation of church and state during the war, as well as described the various understandings of what constituted religious liberty in the United States. In particular, McArthur focused on the discrepancy that developed between clergy and Union officials regarding the clergy's adherence to "“apolitical theology."”749 Most clergy in Missouri "viewed a public endorsement of the North (or South) as a violation of their belief in the strictly spiritual nature of the church and ministry." ${ }^{, 750}$ On the other hand, Union officers and other federal officials strove to silence or remove any Confederate sympathizers or guerrillas from the state by enacting martial law in the region. However, as McArthur explained, "martial law provided the permissive setting" for an "erratic federal campaign against suspected disloyal clergy" in the state "where rumor and speculation ... often

${ }^{748}$ Timothy L. Wesley, The Politics of Faith during the Civil War (Baton Rouge: Louisiana State University Press, 2013).

${ }^{749}$ Marcus J. McArthur, "Treason in the Pulpit: Disloyal Clergy in Civil War Missouri," PhD dissertation, Saint Louis University, 2012, 1

${ }^{750}$ Ibid. 
supplanted specific evidence of disloyalty, resulting in widespread violations of the ministers' civil and religious liberties." ${ }^{, 751}$

Several clerics in the Border States subscribed to apolitical theology because many of their congregations consisted of individuals who supported both sides during the war. Apolitical theology paralleled the political neutrality endorsed by several statesmen in the region. Once the war began, however, the Lincoln administration refused to tolerate neutrality, forcing state governments in the Border South to endorse the Union. As a result, by the end of 1861, all the state governments in the region had officially abandoned their declarations of neutrality and proclaimed support for the federal government. Although the majority of political leaders endorsed unionism, religious leaders in the Border South believed that they could maintain their apolitical stance because they "remained committed to a strictly spiritual church throughout the course of the war." ${ }^{, 752}$ Nonetheless, federal officials expected pastors and priests to publicly support the war in order to garner the cooperation of the local citizenry for the Union cause. By adhering to a neutral stance, clergy raised the suspicions of federal provost marshals and military officers who suspected the apolitical ministers of being disloyal. They argued that the clergy hid behind a façade constructed of false concepts about neutrality and a strict separation of the spiritual and political only to cloak their "true" Confederate sympathies. Therefore, in order to guarantee the loyalty of the clergy, "federal leaders imposed a series of increasingly demanding oaths" upon pastors and

751 Ibid.

752 Ibid., 3. For more information about the course of the Civil War in the Border States or Border South, see: William C. Harris, Lincoln and the Border States: Preserving the Union (Lawrence: University Press of Kansas, 2011); Christopher Phillips, The Civil War in the Border South (Santa Barbara, CA: Praeger, 2013). 
priests in the region that required the ministers "to vow to support the national and state constitutions and refrain from aiding the enemy." 753

Catholics regarded religious tolerance and the separation of church and state as concepts integral to the Church's protection and survival as a minority religion in the United States. Once the war began, Catholic clergy_-particularly in areas such as the Border States—sought to protect religious liberty and defend the notion of a strict separation of the spiritual and political spheres in order to adhere to apolitical theology and to prevent any encroachment from the federal government that might undermine the affairs of the Church. Due to the interconnectedness of the antislavery and anti-Catholic movements before the war, many Church officials feared that once the Civil War ended the federal government would move against the Church in order to fulfill the perceived objective of many northern Protestants: the elimination of both slavery and Catholicism from the United States. ${ }^{754}$ Furthermore, remaining apolitical or adhering to a neutral stance during the war allowed the clergy to carry out their responsibilities as religious leaders and refrain from abandoning a portion of their flocks. Generally, clergy in the North or the South were not plagued with congregations or dioceses containing both Unionists and Confederates; therefore, Catholic officials outside of the Border South often endorsed their respective wartime governments. ${ }^{755}$ Although endorsing a particular

${ }^{753}$ McArthur, 6.

${ }^{754}$ For more information about the interconnectedness of the antislavery and antiCatholic movements during the antebellum period, see: W. Jason Wallace, Catholics, Slaveholders, and the Dilemma of American Evangelicalism, 1835-1860 (Notre Dame, IN: University of Notre Dame Press, 2010); David Goldfield, America Aflame: How the Civil War Created a Nation (New York: Bloomsbury Press, 2011), 17-41; Jon Gjerde, Catholicism and the Shaping of Nineteenth-Century America, edited by S. Deborah Kang (New York: Cambridge University Press, 2012).

${ }^{755}$ Wimmer, 1-15, 89-137. 
cause did not threaten the religious responsibilities of clergy in the North or the South, prelates and priests in the Border States strove to remain neutral thereby maintaining a strict separation of church and state. Throughout the war, Catholic officials in the Border States expressed concern about martial law, the conscription of clergy, confiscation of Church property, and the suppression of civil and religious liberties. The following chapter examines the clergy's responses to these issues and sheds light on the ways in which American Catholics interpreted the conflict, underscores the limitations of religious liberty in a time of civil war, and illustrates the various and fluid understandings of the separation of church and state in American history.

\section{The Effects of Martial Law on the Ministry of the Church}

Following the bombardment of Fort Sumter, the next major event of the Civil War occurred within Archbishop Francis Patrick Kenrick's episcopal see. On April 19, 1861, "armed Massachusetts troops and unarmed Pennsylvania militia" encountered a violent mob in Baltimore as they attempted to pass through the city to defend the nation's capital. ${ }^{756}$ In a letter to the Bishop of Louisville, Kenrick explained the event: "The attack of the troops on the $19^{\text {th }}$ threw our city into great alarm, and the expectation of a descent of other troops on the city thinned churches on the following Sunday."757 Due to the attacks by anti-war protestors and Confederate sympathizers, the Union military declared martial law on May 13, 1861 in the city. ${ }^{758}$ Although federal authority tightened in Baltimore, Kenrick informed Spalding that Catholic "institutions [had] not been

${ }^{756}$ Phillips, 13.

${ }^{757}$ Francis Patrick Kenrick to Martin John Spalding, May 4, 1861, 34-K-51, Associated Archives at St. Mary's Seminary and University, Baltimore, MD (hereafter $\mathrm{AAB})$.

${ }^{758}$ James McPherson, Battle Cry of Freedom: The Civil War Era (New York: Oxford University Press, 1988), 284-288. 
molested" and that there no been "no religious bigotry mixed up with the unfortunate strife." ${ }^{, 759}$ Nonetheless, the archbishop worried about the blending of political and religious spheres during the war. He informed Spalding that in Pittsburgh "the churches were threatened, unless the U.S. flag w[as] raised, and an address w[as] read" in support of the Union. ${ }^{760}$ Although Kenrick stated that he remained "averse to the practice," he noted that "necessity might determine" him to act in support of the federal government so that the Church would be safeguarded. ${ }^{761}$ Evidently, Kenrick felt that he needed to act later that spring, so he prayed for Union officials from his pulpit at the Baltimore cathedral. His actions offended many of the priests at the cathedral as well as members of the congregation, who walked out while Kenrick recited the prayer or "made noises as if to obscure the objectionable words. ${ }^{, 762}$ For Kenrick, Spalding, and other Border State clerics who ministered in divided dioceses, maintaining a separation of church and state in areas governed by martial law proved a particular dilemma throughout the war. Clergy sought to protect the religious liberty of Catholics by preventing any unwarranted interference from the federal government into Church affairs; at the same time, federal officials remained suspicious of Catholic loyalty and pressed bishops and priests to publicly endorse the Union cause.

Several of the Border South clergy believed that the Church could and should maintain a neutral position, despite the individual opinions of its leaders or laity. During the first month of the war, Bishop Richard V. Whelan of Wheeling, Virginia opined that

${ }^{759}$ Francis Patrick Kenrick to Martin John Spalding, May 4, 1861, 34-K-51, $\mathrm{AAB}$.

${ }^{760}$ Ibid.

761 Ibid.

${ }^{762}$ Max Longley, For the Union and the Catholic Church: Four Converts in the Civil War (Jefferson, NC: McFarland Publishing, 2015), 144. 
"our pulpit is not the place for party declarations. The raising too of flags at such a time on our churches is in my opinion, without strong reasons, a most impolitic \& fatal course."763 In his letter to Kenrick, Whelan-one of Kenrick's suffragan bishopschided Catholic bishops in the North for supporting the war; he also referred to the flying of patriotic banners from churches as "a most dastardly act." government demands for the clergy to publicly endorse the Union, Whelan argued that "we [Catholic clergy] could simply have stood upon our rights to hold our church edifices neutral," a clear reference to the separation of church and state. ${ }^{765}$ Whelan sought to maintain a neutral position because, as he explained to Kenrick, "we are a divided people" in Wheeling "uncertain at what hour some exciting event may produce an outbreak."766 Although he sought to maintain a neutral Church for his divided congregation, Whelan admitted to Kenrick that he "fully concur[red]" in the "Virginia ordinance of secession" and vowed to "privately ... stand by it."767 Yet, Whelan was also anguished by his political sentiments because he thought they prevented him from living up to his ideal perception of a religious leader. Whelan's letter suggests that he grappled with keeping his political sympathies private and separate from his duties as a Catholic bishop, admitting to Kenirck: "Indeed I wish I could banish every thought of the kind from my own mind."768

${ }^{763}$ Richard V. Whelan to Francis Patrick Kenrick, April 28, 1861, 32-L-6, AAB. The city of Wheeling is in present-day West Virginia. At the start of the war, Wheeling was located within the boundaries of the Archdiocese of Baltimore.

${ }^{764}$ Ibid.

765 Ibid.

766 Ibid.

${ }^{767}$ Ibid.

768 Ibid. 
Unfortunately for Whelan, Union authorities learned of his true sympathies, so that by May 1862 "an order ha[d] been issued for [his] arrest." ${ }^{769}$ Whelan refused to fly the United States flag from the churches in his diocese, arguing that "only the flag of God should be placed there." 770 Furthermore, he recommended to Archbishop John Hughes of New York that members of the northern Church should recognize Confederate independence. Whelan also published protests against the Lincoln administration in the New York Freeman's Journal. ${ }^{771}$ Although the federal government deemed his actions egregious enough to order his arrest, Whelan considered them "only what as an American I had the right to think \& express. ${ }^{, 772}$ In fact, he informed his metropolitan that he did "not remember a single letter penned in reference solely or chiefly to political matters," nor did he feel any "desire to forsake the sanctuary for the arena of politics.",773 Evidently, Kenrick had encouraged Whelan to demonstrate his loyalty to the Union by raising the flag over his cathedral, taking an oath of allegiance, or performing some formal declaration of his support for the federal government. "Your suggestions that I should furthermore take steps to exonerate myself of the charges made against me,” wrote Whelan, "I must respectfully \& with the truest appreciation of your kind feelings decline to adopt." ${ }^{774}$ Although both Catholic clerics sought to uphold the sanctity of the Church by adhering to a separation of church and state during the war, Kenrick and Whelan demonstrated two different understandings of what constituted a violation of that principle. In order to protect the Church in Baltimore, a city under martial law, Kenrick

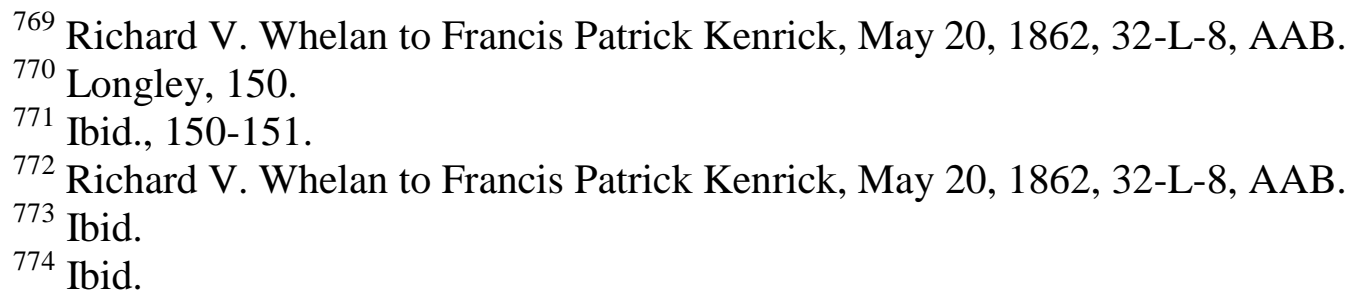


agreed to pray for the Union cause in the cathedral and alluded to the possibility of raising flags over all the city's churches. However, Whelan vowed to uphold a strict separation of church and state, refusing to allow any flags to be flown over churches in the Diocese of Wheeling. The cleric also opposed the policies enacted by the federal government, which he thought had descended into "an avowed despotism" during the war. ${ }^{775}$ Ultimately, Kenrick demonstrated a willingness to blur the lines of the separation of church and state in order to adapt to the contexts of civil war and martial law in his archdiocese; however, Whelan proved unwilling to concede to demands by the federal government, even if that meant risking incarceration during the war.

Although Whelan suggested that the raising of flags on religious institutions proved detrimental to the American Church, the Bishop of Pittsburgh noted that it helped alleviate some of the anti-Catholic prejudices prevalent in the North. Bishop Michael Domenec informed Kenrick that the "effects produced by the expression of our sentiments in favor of the union have been very surprising," noting that the "most bigoted protestants have been softened down.", enemies of our church," wrote Domenec, "have asked our pardon \& they have showed their regret that they ever had said or done anything against the Catholic church.",777 Other northern Catholics wrote to Kenrick to inform him that treasonous activity should not and would not be accepted during the war. After expressing his disdain for those who sought "to cut off the passage of loyal troops through [Baltimore]," George Allen argued that the "Government should show, by their treatment of traitors, that they really believe

\footnotetext{
775 Ibid.

${ }^{776}$ Michael Domenec to Francis Patrick Kenrick, May 16, 1861, 29-C-3, AAB. ${ }^{777}$ Ibid.
} 
we have a Government and that there can be such a crime as $\underline{\text { Treason }}$ - the greatest of crimes."778 A professor at the University of Pennsylvania, Allen told Kenrick that he was "heartily glad to find so very many of our Catholic and Democratic Irish so forward in offering their lives [for] defense of the Union." letters that underscored the positive effects of Catholic support for the Union. Domenec claimed that it alleviated much of the anti-Catholic sentiment that had plagued Pittsburgh during the antebellum period, and Allen highlighted the patriotism of the Irish laity in Philadelphia. Allen also informed Kenrick that anything but unconditional support for the government constituted treason, thereby implying that the Archbishop of Baltimore should make certain that he possessed the appropriate sympathies during the war.

Despite the advice and opinions of Domenec and Allen, as well as the archbishop's "attach[ment] to the Union," Kenrick questioned the policies of the federal government and the actions of Union officials in his archdiocese throughout the war. ${ }^{780}$ In a letter to Spalding, Kenrick noted that he had "always viewed unfavorably the inroads of the Constitution."781 The comment followed his mentioning that several inmates had been released from Fort Warren prison in Boston, Massachusetts. Those whom Kenrick listed in his letter had been city and state officials in Maryland before being arrested by Union officers during the first months of the war. According to Kenrick, the release of Parkin Scott and George Kane, among others, had "given joy to many hearts" in

\footnotetext{
${ }^{778}$ George Allen to Francis Patrick Kenrick, June 2, 1861, 28-C-12, AAB.

779 Ibid.

${ }^{780}$ Francis Patrick Kenrick to Martin John Spalding, December 2, 1862, 34-L-58,

781 Ibid.
} AAB. 
Baltimore. ${ }^{782}$ Not only the incarceration of civil leaders but, more importantly, the arrests of clergy during the war drew the concern of Kenrick. On April 9, 1863, Kenrick claimed that the "Provost Marshall in the neighborhood of Martinsburg ordered all ministers to pray for the federal authorities under penalty of imprisonment and the closing of churches." ${ }^{, 783}$ According to Kenrick, at least one clergyman refused to obey the policy; thus, Union forces arrested him and "compelled [him] to give bail to answer for treasonable practices, and his church was closed by a military force.. ${ }^{, 784}$ Perceiving the event to be a violation of the separation of church and state, Kenrick "wrote forthwith to the President of the U. States, and remonstrated against th[e] violation of ecclesiastical liberty." ${ }^{, 785}$ Kenrick informed Spalding that his letter was forwarded to Secretary of State William H. Seward, who issued the following order to the provost marshal in Baltimore: "[?] no interference with Catholic worship within your district. Release or discharge Revd Dr. Becker."786

During the spring of 1862 , Spalding encountered a similar situation in his diocese. Union officials arrested a priest named Father Jarboe while attending to wounded soldiers near the Tennessee River in Kentucky. According to Spalding, Jarboe attended first to the Confederate wounded and then "thought he would extend his zeal to the Federal" soldiers. ${ }^{787}$ Jarboe adhered to proper protocol, crossing enemy lines "under a flag of

${ }^{782}$ Ibid.

${ }^{783}$ Francis Patrick Kenrick to Martin John Spalding, April 9, 1863, 34-L-61, $\mathrm{AAB}$.

${ }^{784}$ Ibid.

${ }^{785}$ Ibid.

${ }^{786}$ Ibid.

${ }^{787}$ Martin John Spalding to John Baptist Purcell, April 25, 1862, II-5-b, Archdiocese of Cincinnati Collection (hereafter CACI), University of Notre Dame Archives, Notre Dame, IN (hereafter UNDA). 
truce"; nonetheless, when he attempted to return Jarboe "was arrested by the Federal pickets."788 After being detained, Jarboe was "carried before Genl. [William] Nelson" for questioning. ${ }^{789}$ According to Spalding, Nelson "swore at him [Jarboe] like a trooper, or a sailor as he is, \& threatened to hang him high . . . as a rebel spy!",790 Nelson's men detained Jarboe "for a few days" and then "carried him before the Provost Marshall.,"791 “[L]uckily for him,” wrote Spalding, the provost marshal "turned out to be . . a good Catholic convert who knew Father Jarboe" and "gave him a free permit to visit the Federal camps, \& afterwards to go whether [wherever] he pleased.",792 Although the provost marshal had released Jarboe and granted him authorization to minister to soldiers in the Union Army, Spalding worried that the priest would not be able to "get back to the rebels."

For Kenrick and Spalding, the context of the war within the Border Southparticularly the policies enacted by Union officials to preserve loyalty-inhibited or disrupted the Church's ministry in the region. The provost marshal in Martinsburg - a city within the Archdiocese of Baltimore — arrested a clergyman and closed his parish church for refusing to display a United States flag. In writing to Lincoln, Kenrick claimed that the policy violated the religious liberty of Catholic clergy and interfered with Catholic services in the region. Similarly, Union officials in Kentucky seized Father Jarboe and accused him of being a Confederate spy for offering prayers to the wounded of both armies. Despite the fact that the provost marshal in Louisville freed the priest and ${ }^{788}$ Ibid.
${ }^{789}$ Ibid.
${ }^{790}$ Ibid.
${ }^{791}$ Ibid.
${ }^{792}$ Ibid.
${ }^{793}$ Ibid. 
allowed him to minister to Union troops in the area, Spalding doubted that Jarboe would be permitted to return to the Confederate soldiers. Kenrick and Spalding believed that there could be a clear separation of church and state during the war, allowing priests to continue their duties as religious leaders without endorsing a particular cause. During the war, the clerics' foremost concern remained the continuation of Catholic services-for both the civilian and military populations, regardless of their political sympathies—and they interpreted the policies of martial law as impeding the Church's ministry, thereby violating the separation of church and state.

\section{The Conscription of Border State Clergy}

On October 12, 1864, M. Chazal of St. Thomas's Seminary in Bardstown wrote to Father Michael Bouchet, asking him if he had "been drafted for Lincoln's army.",794 "What is the matter, with you," inquired Chazal, for Bouchet had failed to write or visit the seminary. ${ }^{795}$ Chazal assumed that if he had not been drafted then the priest must have at least "engaged [him]self as a substitute," entreating Bouchet to "answer either in person or by letter" so that the clergy at St. Thomas's would be relieved of their worry. ${ }^{796}$ Although Chazal had not been informed, Bouchet received an exemption from military service in December 1863. The "Certificate of Non-Liability" stated that "Michael Bouchet" had "given satisfactory evidence that he [was] not properly subject to do military duty . . by reason of Alienage." ${ }^{, 797}$ Although the Kentucky Board of Enrollment exempted Bouchet, the conscription of clergy proved a particular concern for Catholic

${ }^{794}$ M. Chazal to Michael Bouchet, October 12, 1864, Box 5, Folder 19, Archdiocese of Louisville Records (hereafter CDBL), UNDA.

${ }^{795}$ Ibid.

796 Ibid.

${ }^{797}$ Certificate of exemption from military duty for Michael Bouchet, December 13, 1863, Box 10, Folder 18, CDBL, UNDA. 
officials in the Border States throughout the final two years of the war. In particular, the clergy argued that the forced enrollment of priests into the Union Army violated the separation of church and state.

On March 3, 1863, Congress passed the national conscription act, which according to historian James McPherson, "was designed mainly as a device to stimulate volunteering by the threat of a draft.",798 Although McPherson argued that "[a]s such it worked," the process of conscription proved inefficient and corrupt, and was considered an "injustice" by many citizens in the North and Border States. ${ }^{799}$ As much of the historiography has explained, Catholics — particularly the Irish and German laityopposed conscription, protesting against the draft in several northern and Midwestern cities. The issue also created divisions within the American hierarchy during the war. For example, Archbishop John Hughes of New York proved a devout Unionist and supporter of the Lincoln administration; therefore, he publicly endorsed the draft. Hughes's sentiments were published widely in the North, including a pamphlet that documented a conversation between Hughes and Pope Pius IX about conscription. Hughes informed Pius IX that he would "let volunteering continue," and if not enough men agreed to fight, he suggested that the government "make a draft of three hundred thousand more."800 "It is not cruel," explained Hughes, “This is mercy-it is humanity. This is the way to put an end to this drenching with human blood."801 Nonetheless,

\footnotetext{
${ }^{798}$ McPherson, 600.

${ }^{799}$ Ibid.

800 "Correspondence between Archbishop John, of New York, and Pio Nono, of Rome, on American Affairs," no date of publication, Box 11, Folder 46, CDBL, UNDA, 2. The pamphlet was located within a manuscript containing Martin John Spalding's

801 Ibid.
} handwritten notes and lectures. 
Hughes told the pope that he had "been attacked as if [he] were a man of war," for approving " $a$ thousand conscriptions openly appointed by the Government." 802 Some of those who chided Hughes for supporting conscription included fellow members of the American hierarchy, particularly Bishop Spalding of Louisville. Spalding and other clergy in the Archdiocese of Louisville feared not only the conscription of lay Catholics but more importantly the forced enrollment of Church officials from the Border South. As Spalding explained, the clergy, "being unmarried," had a "double chance of being drafted., 803

Following the passage of the Enrollment Act of 1863, Union officials in Kentucky moved to secure new volunteers. As Spalding feared, the Union officers targeted Catholic seminaries, institutions with concentrated populations of single men. According to a July 1863 letter written by Father Peter Joseph Lavialle, an "enrolling officer ha[d] been around" St. Mary's College_-located five miles west of Lebanon, Kentucky_ looking for recruits. ${ }^{804}$ The arrival of the officer provoked one of the resident priests at St. Mary's, who confronted the Union official. As Lavialle's letter explained, the enrolling officer and "Fr. Peythieu had a regular encounter (only in words, however)," in which the priest referred to "the prohibitions of Canon Law \& the practice of Christian nations in behalf of clergy in general" to explain why the religious men at St. Mary's should be exempted from the draft. ${ }^{805}$ However, the Union official countered by

${ }^{802}$ Ibid.

${ }^{803}$ Martin John Spalding to John Baptist Purcell, January 4, 1864, II-5-b, CACI, UNDA.

${ }^{804}$ Peter Joseph Lavialle to Michael Bouchet, July 29, [1863], Box 4, Folder 10, CDBL, UNDA. ${ }^{805}$ Ibid. 
"doggedly pointing to his written regulations," which undoubtedly, authorized the conscription of members of the religious community. ${ }^{806}$

In order to avoid similar confrontations between enrolling officers and Catholic clergy, Bishop Spalding endeavored to "procure the passage of an amendment to the ... Conscription bill, exempting all clergymen "who have no other occupation or profession, $\&$ who devote their whole time to the holy ministry or to teaching." $" 807$ Although Spalding feared that the amendment would "scarcely pass," he informed his metropolitan that members of his diocese sought to "stem the torrent of fanaticism in this onslaught on the rights of our clergy." ${ }^{\prime 808}$ In particular, Spalding considered conscription "a deep[1y] un-Catholic scheme" concocted by the federal government to privilege Protestant preachers because exemptions were given to those clergy who could marry. ${ }^{809}$ However, Spalding's primary argument against the conscription of clergy involved his belief that it violated the separation of church and state. As he explained in his diocesan journal: "It is the duty of each priest and even more the duty of Bishops not to strive by arms but to offer our prayers before the altar ... since the church abhors bloodshed." ${ }^{\prime 810}$ In Spalding's opinion, the conscription of clergy violated the separation of church and state because he considered it the Church's responsibility to "direct the souls of [the] hearers and readers towards heavenly things," rather than meddle "in the political agitations

\footnotetext{
806 Ibid.

${ }^{807}$ Martin John Spalding to John Baptist Purcell, January 4, 1864, II-5-b, CACI, UNDA ${ }^{808}$ Ibid.

809 Ibid.

${ }^{810}$ Baltimore Journal of Martin John Spalding (transcript), Box 3, Folder 14, Archdiocese of Baltimore Collection (hereafter CABA), UNDA, December 1, 1864, p. 7.
} 
which came before the war and concommitent [sic] with the war." ${ }^{811}$ As the bishop explained, "the Catholic church is not a human but a fully divine society, founded by God himself, and elevated above all human agitations. In this way, indeed, they [the federal government] are obviously able to distinguish the church of Christ from human sects." Although many members of the American Church opposed conscription for political or economic reasons, clergy within the Archdiocese of Louisville utilized arguments about religious liberty and the separation of church and state to attack the federal policy. The confrontation between Father Peythieu and the enrolling officer at St. Mary's College revealed the problems related to the contrasting viewpoints of the Church and the federal government during the war. Peythieu referred to religious doctrine and underscored the rights of clergy to argue that Catholic clergy should be exempted from enrollment in the army. At the same time, however, the Union official referenced his authorization papers, noting that federal law required the enlistment of clergy. Spalding parroted the arguments of Father Peythieu, claiming that Church officials should answer only to spiritual authority and not be forced to adhere to the federal policy. Spalding also argued that the conscription bill reflected the anti-Catholic sentiments associated with the Lincoln administration and the Republican Party. In his opinion, Union officials breached the separation of church and state by enacting a bill that required the enrollment of clergy because they abhorred the Catholic Church.

The Use, Confiscation, and Destruction of Church Property during the War

During the first half of the nineteenth century, Catholics established institutions of higher education-including seminaries and colleges—-throughout central Kentucky. In

811 Ibid.
${ }^{812}$ Ibid. 
particular, Catholic officials in the state considered the seminaries essential to the growth of the Church in the Ohio Valley because they educated new clergy. ${ }^{813}$ Unfortunately, however, the start of the Civil War disrupted the activities at many of the Catholic colleges and seminaries in the state. According to Bishop Martin John Spalding, the number of scholars at St. Joseph's College in Bardstown, Kentucky dropped from 175 to 40 during the first year of the war. He attributed the loss of students to "the fruit of the miserable civil war which is [now] raging" in Kentucky. ${ }^{814}$ The war not only affected the school's enrollment but the institution also fell into the hands of Union forces stationed in the state. According to Spalding, instructors at the college suspended classes on December 25, 1861 because the "military occupi[ed] a portion of [it] through 'military necessity,' and requisition. ${ }^{815}$ The actions of the commanding officer angered Spalding because he ordered the occupation of the college "without waiting for the approbation of [himself or the] Moderator of the Board of Trustees," despite what the "Faculty requested!" ${ }^{816}$ According to Spalding, the "hard times of military necessity" had taken "the place of law." 817 Certainly, Spalding perceived the occupation of St. Joseph's College to constitute a violation of a law that prevented state interference with Catholic

${ }^{813}$ For more information about Catholic education in Kentucky, see: Andrew H. M. Stern, Southern Cross, Southern Crucifix: Catholic-Protestant Relations in the Old South (Tuscaloosa: The University of Alabama Press, 2012), 70-107.

${ }^{814}$ Journal of Martin John Spalding, Bishop of Louisville, April 8, 1860-March 27, 1864 (transcript), Box 10, Folder 9, Archdiocese of Louisville Records (hereafter CDBL), University of Notre Dame Archives, Notre Dame, IN (hereafter UNDA), December 1861, p. 21. Peter E. Hogan transcribed the journal in April 1950 and provided a copy to the University of Notre Dame Archives. The original diocesan journal is located in the Department of Archives and Manuscripts, Mullen Memorial Library, Catholic University of America, Washington, DC. The transcript will be cited hereafter as (Spalding Journal, CDBL, UNDA).

${ }^{815}$ Ibid.
${ }^{816}$ Ibid.
${ }^{817}$ Ibid. 
property. Indeed, for the duration of the war, Spalding and other Catholic officials in the Border States encountered situations that involved the use of Church property to support the Union war effort. During each incident, the clergy expressed concern about maintaining a strict separation of church and state and protecting the religious liberty of Border State Catholics.

However, not all episodes proved as confrontational as the occupation of St. Joseph's College. After learning about the incident, Spalding wrote to "Gen'l Wood," the commander of the Union forces at St. Joseph's, to demand that the "Nazareth Academy" - the religious institution for females near Bardstown—not "be molested." 818 After receiving Spalding's letter, Wood "answered politely" and proceeded to Nazareth to "assure the Sisters of his protection," behaving "well and like a Kentucky gentleman." ${ }^{819}$ Similarly, Father Peter Joseph Lavialle reported from St. Mary’s College that "no interruption from the troops" had occurred, an evasion that he attributed to the work of "a protecting Providence." ${ }^{, 20}$ Furthermore, some Union troops who occupied institutions during the war offered a monetary recompense for Catholic hospitability. Father P. P. Cooney, chaplain of the $35^{\text {th }}$ Indiana, sent " $\$ 25$ from the men of our regiment" to Father Chambige for the "kindness" shown to the Union troops while they were stationed at St. Thomas's, a seminary near Bardstown. ${ }^{821}$ Cooney suggested that the money be used for "whatever charitable purpose" Chambige chose, indicating that the regiment hoped to send "more material aid to St. Thomas' \& the Asylum-institutions so

${ }^{818}$ Ibid., January 16, 1862, p. 23.

819 Ibid.

${ }^{820}$ Peter Joseph Lavialle to Michael Bouchet, June 13, 186[?], Box 4, Folder 10, CDBL, UNDA. UNDA.

${ }^{821}$ Chambige to P. P. Cooney, December 22, 1862, Box 5, Folder 24, CDBL, 
dear to God." ${ }^{822}$ Other Catholic institutions suffered from the activities of guerrillas. Similar to their concerns about Union forces interfering with Church activities, clergy mentioned the material destruction caused by Confederate raiders. In September 1864, Father Lavialle noted that the "late capture of the train by guerillas" cost St. Mary's College " $\$ 300$ worth of goods." 823 Ultimately, the raid proved a "heavy loss" on the Catholic community near Lebanon. ${ }^{824}$

Nevertheless, Catholic clergy argued that the Union Army was responsible for the majority of the confiscation and destruction of Church property during the war. In particular, Bishop Spalding's "Dissertation on the American Civil War" included several references to the destruction of Catholic institutions at the hands of federal troops. ${ }^{825}$ Completed during the spring of 1863, Spalding's dissertation arrived in Rome, where it was "presented ... to the Holy Father" and subsequently published during the fall of 1863 in Osservatore Romano, an official Vatican periodical. ${ }^{826}$ Published under the subtitle "What is the Relation of the War with the Catholic Religion," Spalding offered the following as evidence of the wartime damages against the Church:

According to what has been published in their newspapers without contradiction, the troops of the North have already burned at least three Catholic churches in their invasion of the South . . . Moreover, in Missouri and elsewhere, they have already perpetrated great sacrileges in other Catholic churches. ${ }^{827}$

822 Ibid.

${ }^{823}$ Peter Joseph Lavialle to Michael Bouchet, September 6, 1864, Box 2, Folder 3, CDBL, UNDA.

${ }^{824}$ Ibid.

${ }^{825}$ David Spalding, editor, "Martin John Spalding's 'Dissertation on the American Civil War,"' The Catholic Historical Review 52 (April 1966): 66-85.

${ }^{826}$ Ibid., 68.

${ }^{827}$ Ibid., 84. 
Although the depredations may have occurred due to "the license of badly disciplined soldiers," Spalding was abhorred that "no one ha[d] been punished ... for such sacrileges and burnings." ${ }^{828}$ According to the bishop, the Union troops received no chastisement because "all, or nearly all, the leaders (chiefs) of the movement of the North, hate the Catholic religion with an almost satanic hate." ${ }^{829}$ He described the destruction of Church property as acts conducted "in hatred of religion," and feared that "as soon as the revolt of the South [was] over" the federal government would lead a campaign "to attack the Catholic religion.. ${ }^{830}$ Thus, in Spalding's opinion, members of the Union war effort confiscated or destroyed Church property because they maintained anti-Catholic sentiments. In addition, federal troops targeted religious sites and performed sacrilegious acts in a war that the bishop considered solely a political contest. As a result, Spalding indicated in his dissertation that the Union war effort had violated the separation of church and state and infringed on the religious liberty of American Catholics.

In addition to the use, occupation, or destruction (depending on the perspective) of physical property during the war, Union officials also sought to acquire the services of Catholic sisters and nuns. Throughout the war, Catholic women religious offered their services as caregivers and nurses for the Union Army. ${ }^{831}$ Although members of the Church hierarchy deemed it their duty to care for the wounded, they worried about providing women religious to the Union Army because they feared that the government

${ }^{828}$ Ibid.

${ }^{829}$ Ibid.

${ }^{830}$ Ibid.

${ }^{831}$ For more information on the service of Catholic women religious during the war, see: Benjamin J. Blied, Catholics and the Civil War (Milwaukee, WI: privately published, 1945), 108-123; William B. Kurtz, "Roman-Catholic Americans in the North and Border States during the Era of the American Civil War," PhD dissertation, University of Virginia, 2012, 128-202. 
would assert too much authority over the sisters. In September 1861, Bishop Spalding drafted an agreement with Union General Robert Anderson concerning the use of the Sisters of Charity in military hospitals in Louisville. Spalding included a copy of the agreement in a letter to the Archbishop of Cincinnati:

1. The Sisters of Charity will nurse the wounded under the direction of the army surgeons, without any intermediate authority or interference whatsoever.

2. Every thing necessary for the lodging \& nursing of the wounded \& sick will be supplied to them without putting them to expense, they giving their services gratuitously.

3. So far as circumstances will allow, they shall have every facility for attending to their religious \& devotional exercises. ${ }^{832}$

In particular, Spalding sought to restrict the authority of the Union Army because he associated members of the federal government with anti-Catholicism. "I am not at all surprised by the bigots," wrote Spalding, "It is precisely what I expected from those who now flatter Catholics because they need them." ${ }^{\text {,33 }}$ Yet, Spalding believed that the federal officers would "kick them so soon as they [could] dispense with their services.",834

The anti-Catholic sentiment associated with the Union Army also plagued the relationship between the Archbishop of Baltimore and the commanding officer of federal troops in his archdiocese. On December 17, 1861, Francis P. Kenrick wrote to "Major General [John Adams] Dix" about a charge made by "the Government" regarding "ladies" dressed "in the costume of Sisters of Charity, furnished at the Convent at Emmitsburg[, Maryland]." 835 According to members of the federal government, the sisters had "passed the lines into Virginia ... for the purpose of keeping up

${ }^{832}$ Martin John Spalding to John Baptist Purcell, October 29, 1861, II-5-a, CACI, UNDA.

833 Ibid.

834 Ibid.

${ }^{835}$ Literarum Registrum (Letter Register) of Francis Patrick Kenrick, 1851-1862, 32-B-Z1, AAB, 235. 
communication with the Confederate States. ${ }^{\Perp 836}$ During the antebellum period, several popular anti-Catholic tales portrayed Church priests and nuns as secretive and conspiratorial. Certainly, the perception of the Catholic Church as a devious regime-a belief that permeated much of nineteenth-century American culture-influenced the federal government's accusation about the supposed "sister spies" and shaped Kenrick's response to Dix. ${ }^{837}$ According to Kenrick, the "Sisters of Charity were employed in the works of their institute . . long before the formation of the S. Confederacy"; furthermore, the women religious had "occasionally passed to their home [in Emmitsburg], and returned to the work of charity, but [had] always openly, and without concealment, [and] with the permission of the authorities." ${ }^{838}$ Above all, Kenrick informed Dix that the sisters had "not at any time lent themselves to any object of a political or treasonable character, or in the slightest degree departed from the objects of their calling." " 839 "If any illicit correspondence has been carried on by any persons wearing the costume of the Sisters of Charity," stated Kenrick, "it has certainly not been by members of their Institute, or with means furnished by the Community of Emmitsburg." ${ }^{" 840}$ In addition, Kenrick assured Dix that the "Superior of that Institution

${ }^{836}$ Ibid.

${ }^{837}$ For more information about popular anti-Catholic tales in antebellum America, see: Jenny Franchot, Roads to Rome: The Antebellum Protestant Encounter with Catholicism (Berkeley: University of California Press, 1994); Susan M. Griffin, AntiCatholicism and Nineteenth-Century Fiction (New York: Cambridge University Press, 2004); Tracy Fessenden, Culture and Redemption: Religion, the Secular, and American Literature (Princeton, NJ: Princeton University Press, 2007); Elizabeth Fenton, Religious Liberties: Anti-Catholicism and Liberal Democracy in Nineteenth-Century U.S.

Literature and Culture (New York: Oxford University Press, 2011).

${ }^{838}$ Literarum Registrum (Letter Register) of Francis Patrick Kenrick, 1851-1862, 32-B-Z1, AAB, 235-236.

${ }^{839}$ Ibid., 236.

${ }^{840}$ Ibid. 
will cheerfully afford the Government any particulars in their power, and satisfy them that they have given no countenance or aid to any movement of an unlawful character." 841

Clearly, issues regarding Church property and the use of Catholic women religious for the Union war effort concerned clergy in the Border States. As Spalding explained, the war itself disrupted the ministry of the Church by negatively affecting enrollment at Catholic religious and educational institutions in the region. For Church officials, the institutions proved vital for the preservation and growth of their religion in the Border South and nation. Despite the need for Union officials to procure institutions to serve as hospitals and military headquarters, Catholic clerics deemed the confiscation of Church property to be unlawful acts that violated the separation of church and state. Furthermore, the pervasiveness of antebellum anti-Catholicism colored the relationship between Church and federal officials. Spalding attributed the destruction of Church property, as well as the lack of punishment for such destruction, the products of religious prejudice among northern politicians and preachers. Similarly, anti-Catholicism impacted the use of women religious during the war, as Spalding sought to safeguard their religious liberty from Union officials in Louisville and Kenrick dealt with accusations about treasonous activity among the Sisters of Charity in Maryland. Overall, the evidence indicates that Catholic officials in the Border South worried foremost about protecting the Church in the region, while members of the Union war effort considered a Confederate defeat more important than upholding a strict separation of church and state. Opposition to Loyalty Oaths and the "union of church \& state"

${ }^{841}$ Ibid. 
For Catholic clergy in the Border South, test oath requirements represented the obvious violation of the separation of church and state. Most of the clergy, whether at the congregational or diocesan level, ministered to a divided populace. As Wesley and McArthur explained in their works on the political sympathies of clerics during the war, most Border State clergy sought to avoid entering into the political sphere or publicly endorsing either the Union or the Confederacy. Remaining apolitical or adhering to a neutral stance during the war allowed the clergy to carry out their responsibilities as religious leaders and refrain from abandoning a portion of their flocks. Generally, clergy in the North or the South were not plagued with congregations or dioceses containing both Unionists and Confederates; therefore, Catholic officials outside of the Border South often endorsed their respective wartime governments. Although endorsing a particular cause did not threaten the religious responsibilities of clergy in the North or the South, priests and bishops in Missouri, Kentucky, and Maryland strove to remain neutral and avoid subscribing to an oath of allegiance, thereby maintaining a strict separation of church and state.

Ministering in a diocese that witnessed several anti-Catholic demonstrations during the mid-1850s, Bishop Martin John Spalding promoted a strict separation of church and state before the Civil War began. Events such as the Louisville "Bloody Monday" Riot of 1855 demonstrated to Spalding the need to protect the Church from a hostile Protestant populace. ${ }^{843}$ In the decades before the war, Spalding and other Catholic UNDA.

${ }^{842}$ Martin John Spalding to John Baptist Purcell, April 23, 1864, II-5-b, CACI,

${ }^{843}$ For more information about the Louisville "Bloody Monday" Riot, see: Agnes Geraldine McGann, Nativism in Kentucky to 1860 (Washington, DC: The Catholic University of America, 1944); Emmet V. Mittlebeeler, “The Aftermath of Louisville's 
clerics utilized the concept of the separation of church and state to argue that the use of the King James Bible and required readings of the Protestant Ten Commandments in public schools violated the religious liberty of Catholics. ${ }^{844}$ As Spalding explained, "the state [should] have nothing whatever to do with religious [education], leaving this where the constitution leaves it—in the hands of pastors and priests." ${ }^{845}$ Spalding and other Border State clergy considered the separation of church and state vital to the protection of Catholic traditions from encroachments by members of state and federal governments, who sought to impose Protestant teachings on all Americans. Thus, a tradition of upholding the separation of church and state developed among Catholic clergy during the antebellum years which shaped their interpretations of Union policies during the Civil War. In particular, bishops and priests considered required loyalty oaths direct violations of their religious liberty and a violation of the separation of church and state.

On March 16, 1862, Spalding reported in his diocesan journal that he had "[r]eceived news of [a] law passed by [the state] Legislature requiring [an] oath from all ministers \& priests before solemn[izing] marriage." ${ }^{846}$ After learning about the required oath, Spalding "wrote to Governor [Beriah] Magoffin protesting against it." 847 Spalding listed a number of reasons why he thought the test oath law should be "annulled or

Bloody Monday Election Riot of 1855," Filson History Quarterly 66 (April 1992): 197219; Luke J. Ritter, "Anti-Catholic America: Nativism and Religious Freedom in the Antebellum West," PhD dissertation, Saint Louis University, 2014.

${ }^{844}$ For more information about the contestation between Protestants and Catholics over public education during the nineteenth century, see: John T. McGreevy, Catholicism and American Freedom (New York: W.W. Norton \& Company, 2003), 19-40; Gjerde, 140-174.

${ }^{845}$ Lecture notes of Martin John Spalding, November 22, 1858, Box 10, Folder 45, CDBL, UNDA.

${ }_{847}^{846}$ Spalding Journal, CDBL, UNDA, March 16, 1862, p. 29. ${ }^{847}$ Ibid. 
quietly dropped," which according to the bishop, Magoffin included in his "veto message" to the Kentucky legislature. ${ }^{848}$ Influencing and in concordance with the opinions of the Democratic governor, Spalding included a copy of Magoffin's veto message in his official diocesan journal. Magoffin outlined eight points of rebuttal in his statement, concluding overall that the law proved "an unnecessary annoyance to the clergy, who [did] not need such a test of loyalty." ${ }^{\prime 849}$ An analysis of the message shows that Spalding's influence and concerns about the Catholic Church shaped much of Magoffin's message. "It was the design of the framers," wrote Magoffin, "to prevent a union of Church and State; to prevent the interference of politics with religion, or religion with politics; to define and separate secular from spiritual duties and, in my judgement, to ignore and discountenance all test $\underline{\text { oaths }}$ in the performance of religious ceremonies." Furthermore, the governor's statement noted that "[s]olemnizing marriage is a religious duty ... The Catholics hold the rite of marriage a sacrament . . . instituted by Christ, and by Him invested with all the sacredness in its order."

Magoffin also suggested that the oaths could be used to persecute religious minorities, like Catholics. Reminding members of the Kentucky Congress that "not many years ago, the spirit of intolerance and religious persecution was so rife in our country that a powerful party was formed [Know-Nothings] ... which threatened for a time the destruction of their church [Catholics]," Magoffin argued that the oaths might be used to "discriminate between the various denominations of Christians." 852 "[M]ay not
${ }^{848}$ Ibid.
${ }^{849}$ Ibid., p. 33.
${ }^{850}$ Ibid., p. 31.
${ }^{851}$ Ibid.
852 Ibid. 
the Protestants impose test oaths on Catholics," asked Magoffin, or perhaps "Catholics upon Protestants, if they happen to have political power, or the Protestants, as they widely differ in their political opinions, impose them upon each other [?]"853 Finally, Magoffin opposed the oath because he considered it compatible to the work of New England ministers who commonly mixed "civil and religious ideas" and promulgated "abolition preaching." $" 854$ Despite the contestations of Spalding, Magoffin, and other Kentuckians, the state legislature overrode the governor's veto and enacted the loyalty oath law. On September 8, 1862, Spalding "[t]ook the oath demanded by the vexatious and unnecessary act of [the] last Legislature." ${ }^{855}$ Although he complied with the law, Spalding included the following protest:

I, the undersigned as a law-abiding citizen, take the following oath, deeming it my duty, however, to protect against the same as a precedent chiefly on the ground, among other reasons, that it requires a civil act as an essential preliminary to the performance of a spiritual office, marriage being solemnly regarded by the Catholic \& by all the old Churches - embracing about or nearly five-sixths of Christendom to be a holy Sacrament belonging to the spiritual order, \& therefore according to the ... spirit of our Constitution, not subject for its performance by a Christian minister to merely local or civil laws. ${ }^{856}$

Spalding's protest indicates that the prelate opposed the oath because he believed that it violated the separation of church and state. In his opinion, the Kentucky legislature had enacted a secular requirement for the administration of a holy sacrament. Although he did not state specifically, Spalding probably complied with the oath to avoid unwarranted confrontation with Union officials in the state. By swearing his allegiance to the Union, Spalding could continue his ministry as leader of the Diocese of Louisville; nonetheless,

853 Ibid.

${ }^{854}$ Ibid., p. 33.

${ }^{855}$ Ibid., September 8, 1862, p. 39. According to the transcription, Spalding crossed out "tyrannical" and replaced it with "vexatious and unnecessary." ${ }^{856}$ Ibid. 
he made known his concern for a perceived encroachment of the state into the religious sphere.

Similar to Spalding, other clergy in the Diocese of Louisville opposed the required loyalty oaths. In September 1863, Reverend Michael Bouchet wrote that he hoped to participate in a "charitable mission ... [for] the poor dying negroes" impacted by the war. ${ }^{857}$ "At first I offered my services," wrote Bouchet, but later he discovered "serious obstacles" to his mission. ${ }^{858}$ In order to continue his services in the care of displaced slaves, Bouchet was required "to take an oath of allegiance"; however, he refused to comply because he was "a subject of France" and not "prepaired [sic]" to support "either side" during the war. ${ }^{859}$ Instead, Bouchet suggested to John Baptist Purcell, the Archbishop of Cincinnati, that the "colonel priests" of the North, "who came so near suffering martyrdom, in trying to raise recruits," should "make the same sacrifice" in carrying for African Americans in the South. ${ }^{860}$ Although he hoped "to put the negroes under Catholic influence," Bouchet refused to subscribe to the oath, noting the inconvenience it caused for ministers of the Church. ${ }^{861}$

Other clergy in Kentucky simply refused to adhere to the policies enacted by the state government, choosing instead to perform religious services without subscribing to the oath. In an April 1864 letter, Bishop George A. Carrell informed Purcell that when he visited Kentucky he could "perform any function \& exercise all faculties" in the

${ }^{857}$ Michael Bouchet to John Baptist Purcell, September 23, 1863, Box 4, Folder 39, CDBL, UNDA.

${ }^{858}$ Ibid.

${ }^{859}$ Ibid.

${ }^{860}$ Ibid.

${ }^{861}$ Ibid. 
Diocese of Covington. ${ }^{862}$ Although Carrell noted that clergy required "an oath" in order "perform a marriage ceremony in the state," he reminded Purcell that he insisted on performing the sacraments regardless of the law. ${ }^{863}$ Other clergy argued that Catholic officials should subscribe to the oath of allegiance to avoid disruption of the Church's ministry. Bishop John Timon of Buffalo, New York directed Archbishop Francis Patrick Kenrick to "persuade" one of his bishops to "take the oath of allegiance," because Timon believed that "His Holiness would also advise [the prelate] to take it" given "the circumstances" of the war. ${ }^{864}$ According to Timon, the bishop had been "harshly treated, and ever [?] with confiscation because he would not take the oath"; therefore, Timon recommended that clergy in politically divided archdioceses like Baltimore adhere to the test oath laws in order to avoid confrontation with the federal government. ${ }^{865}$

In addition to opposing loyalty oaths, Bishop Spalding also attested the interference of the federal government in American Church affairs. In July 1863, Francis Patrick Kenrick died, leaving the episcopal see open in Baltimore. During the spring of 1864, Pope Pius IX appointed Spalding to fill the position. News of his transfer concerned both the Church hierarchy and members of the federal government. In an April 1864 letter to the Archbishop of Cincinnati, Spalding wrote: "I have just learned ... that one of our prelates has already declared his intention ... to sound the government as to whether its officers will be willing for me to go to Balt.!!"866 The clergyman's actions

${ }^{862}$ George A. Carrell to John Baptist Purcell, April 22, 1864, II-5-b, CACI, UNDA. ${ }^{863}$ Ibid.

${ }^{864}$ John Timon to Francis Patrick Kenrick, June 11, 1863, 31-T-68, AAB. 865 Ibid. UNDA.

${ }^{866}$ Martin John Spalding to John Baptist Purcell, April 23, 1864, II-5-b, CACI, 
worried Spalding, for the bishop considered communication with the government about his appointment "ill-advised" and representative of a "union of church \& state." 867 A month later, Spalding informed Purcell that the prelate, "who declared his intention of conferring with the government officials," had written him and offered his version of the exchange. ${ }^{868}$ Bishop Michael Domenec of Pittsburgh had spoken “"with Gov. Seward [who] asked if it was true" about Spalding "being appointed for the See of Baltimore.",869 Domenec confirmed the information and informed the secretary of state that Spalding “"never wished to speak on politics, much less to meddle with them.",870 Although Spalding believed that Domenec had "acted from good motives," the newly appointed Archbishop of Baltimore sought to maintain a strict separation of church and state, and in his opinion, the communication between Domenec and Seward represented a federal infringement into Catholic affairs. ${ }^{871}$

Arguably, the most well-known incident involving the American Church and loyalty oaths or the separation of church and state during the war occurred in the Archdiocese of St. Louis, Missouri, where Peter Richard Kenrick served as the archbishop. Early on during the war, Kenrick declared his opposition to required loyalty oaths in the state. By the summer of 1861, Unionists had taken control of Missouri, establishing a provisional state government. In order to secure the loyalty of Missourians, the provisional government enacted a test oath requirement for all public officials, including clergy. However, Kenrick and other Catholic clergy in the state

${ }^{867}$ Ibid.

${ }^{868}$ Martin John Spalding to John Baptist Purcell, May 19, 1864, II-5-b, CACI, UNDA.

${ }^{869}$ Ibid.

870 Ibid.

871 Ibid. 
refused to take the oath, considering " "the de facto government to be revolutionary and illegal. ${ }^{\prime 872}$ Although the provisional government enacted the oath in October 1861 and passed an ordinance outlining three forms of test oaths in June 1862, state authorities made "no serious effort ... to enforce either [the] ordinance or [the law] passed" in the fall of $1861 .{ }^{873}$ Nonetheless, by the final year of the war, Missouri had come under the control of Radical Republicans, who won a majority of state offices in the November 1864 election. Once in control, the Radical Republicans held a constitutional convention, which began on January 1, 1865 and concluded three months later with the adoption of a new state constitution, commonly referred to as the Drake Constitution. In addition to ordering the "immediate and unconditional emancipation of all slaves in Missouri," the Drake Constitution put forward an “'iron-clad' test oath," required for “"any person ... competent as a bishop, priest, deacon, minister, elder, or other clergyman of any religious persuasion, sect, or denomination, to teach, or preach, or solemnize marriages." ${ }^{\text {874 }}$

Although the oath requirement did not go into effect until September 2, 1865, Kenrick declared early on that clergy within his archdiocese would not adhere to the policy. On July 25,1865 , he issued the following circular to the clergy of the Archdiocese of St. Louis:

Since under the new Constitution a certain oath is to be exacted of priests, that they may have leave to announce God's word, and officiate at marriages, which oath they can in nowise take without a sacrifice of ecclesiastical liberty, I have judged it expedient to indicate to you my opinion in the matter, that you may have before your eyes a rule to be followed in a case of this delicacy. I hope that the civil power will abstain from exacting such an oath. But should it happen

${ }^{872}$ Mary Emmanuel White, "Archbishop Peter Richard Kenrick and the Civil War," MA thesis, Saint Louis University, 1948, 83.

${ }^{873}$ Ibid., 85 .

${ }^{874}$ Ibid., 87-89. 
otherwise, I wish you to inform me of the particular circumstances of your position, that I may be able to give you counsel and assistance. ${ }^{875}$

As his circular explained, Kenrick vowed to offer advice to each cleric about whether or not the priest should subscribe to the loyalty oath. The evidence suggests that Kenrick advised against taking the oath, for as Father Pierre De Smet explained “"our [the clergy's] authority does not emanate from the State, and we cannot, without compromising the ecclesiastical state, consent to such an oath. [Therefore,] No Catholic priest in Missouri will take it." ${ }^{\prime 876}$ Furthermore, a month after distributing his circular within the archdiocese, Kenrick explained his position against the oath in a private correspondence to Spalding. Writing in August 1865, Kenrick charged that the oath proved "so glaring an assumption of the power to prescribe conditions for our competency to discharge the duties imposed on us by the Church" that the archbishop was left with "no alternative but to direct the clergy to refuse [the] oath." ${ }^{877}$ Furthermore, he considered the oath and the Drake Constitution products of "one of the most tyrannous systems of misgovernment ever imposed on a conquered people." ${ }^{878}$ Although Kenrick knew that he put his clergy at risk of "six months imprisonment," he reassured Spalding that "[e]very priest in Missouri will preach and marry after the $4^{\text {th }}$ [of September] just as before," thereby ensuring that the Church's ministry would continue. ${ }^{879}$

Ultimately, the clergy and Union officials in Missouri refused to concede their positions regarding the oath; therefore, arrests of clergy commenced in the fall of 1865 .

875 Ibid., 90.

876 Ibid., 91.

${ }^{877}$ Peter Richard Kenrick to Martin John Spalding, August 30, 1865, 34-M-15, AAB.

878 Ibid.

${ }^{879}$ Ibid. 
A month after the oath law went into effect, Kenrick informed Spalding that "seven, at least, of our priests have been arrested or indicted," due to the policies of the "point of bayonet' Governor" of Missouri. ${ }^{880}$ Arrests continued throughout November and December of 1865, for on January 6, 1866, Kenrick opened his letter to Spalding with the following statement: "I cannot say that our prospects at the commencement of the year are very encouraging. Arrests of priests continue to be made out of St. Louis County. In Cape Girardeau five Lazarists ${ }^{881}$ were indicted, four of whom were arrested and held to bail for the violation of the ... enactment [for] preaching and and marrying without having taken the oath." ${ }^{, 82}$ Fortunately for the priests, the grand jury of St. Louis County had "hitherto refused to indict any clergymen"; nonetheless, "a new Grand Jury ha[d] been called" and Kenrick feared that the new jurists would not "follow the example of the former." 883 In addition to the policies of the Radical Republicans, Kenrick attributed the dire conditions of his archdiocese to the effects of the "days of Military Rule" in Missouri under the direction of Union General William Starke Rosecrans. ${ }^{884}$ Due to the policies of martial law, clergy in the Archdiocese of St. Louis could "neither hold a council, nor assemble ... for [a] conference or Retreat, without infringing an order of Genl Rosecranz [sic]." ${ }^{885}$ If the clergy assembled without taking "one of the many oaths," the Catholic

${ }^{880}$ Peter Richard Kenrick to Martin John Spalding, November 6, 1865, 34-M-17, AAB.

${ }^{881}$ Term used to denote members of the Congregation of the Mission.

${ }^{882}$ Peter Richard Kenrick to Martin John Spalding, January 6, 186[6], 34-M-10, AAB. Although Kenrick dated the letter " 6 " Jan 1865," he mentioned the "case of Rev J. Cummings brought by appeal to the S. Court of the U.S."; therefore, he misdated the letter.

${ }^{883}$ Ibid.

${ }^{884}$ Peter Richard Kenrick to Martin John Spalding, June 27, 1865, 34-M-14,

AAB.

${ }^{885}$ Ibid. 
officials faced a "penalty of arrest and incarceration!" $" 886$ Thus, the combination of state laws enacted by the Radical Republican majority and the policies of martial law in Missouri created an environment in the Archdiocese of St. Louis that inhibited the activities of the Church. To Catholic clergy, the policies represented a violation of the separation of church and state by both the state and federal governments.

According to historian Marcus J. McArthur, the clergy's decision to continue practicing in the state — holding mass and administering the sacrament of marriagewithout taking the oath of allegiance represented acts of "civil disobedience," because they sought to keep the state's power subordinate to "God's higher law." ${ }^{887}$ As McArthur explained, "[t]o take the oath would have been to acknowledge the state's power to determine who could preach in God's churches." ${ }^{888}$ In particular, the decision made by Father John A. Cummings to continue his ministry without adhering to Missouri law garnered national attention, including the action of the Supreme Court of the United States. In early September 1865, Union officials arrested Cummings for continuing to hold services at his Irish Catholic parish in Louisiana, Missouri without signing the oath of allegiance. Shortly after his arrest, a grand jury convened and indicted Cummings for violating the test oath law. At his arraignment, Cummings pled guilty; nevertheless, he declared that he "was guilty of an unjust law" and "accused the Radical state regime of attempting to persecute the Roman Catholic Church." ${ }^{1899}$ According to Kenrick, Cummings "was for six days incarcerated, but liberated on appeal to the Supreme Court
${ }^{886}$ Ibid.
${ }^{887}$ McArthur, 211.
888 Ibid.
${ }^{889}$ Ibid., 219. 
of the State." ${ }^{\circledR 90}$ Nevertheless, the Supreme Court of Missouri upheld the original "sentence of the lower court," which did not surprise Kenrick, for he noted that the state judges served only the "party which ha[d] thrust them into office." ${ }^{891}$ As a result, Kenrick informed Spalding that "we have been obliged to appeal to the Supreme Court of the U. States." 892 According to a biography of Kenrick, the prelate chose Cummings "to be the victim of the test" against the required loyalty oath, and once Cummings was arrested, his case "formed the nucleus of the Archbishop's fight against the meddling of the State in Church affairs."

Although Cummings appealed the ruling in late 1865, the Supreme Court of the United States did not begin to hear opposing counsels in the case of Cummings $v$. Missouri until March 1866. Kenrick "hoped that the case ... would have an early hearing," so he sought assistance from members of the federal government. ${ }^{894}$ Although "Attny Genl. [James] Speed, by direction of the President, moved that the case be called up ... on the list," members of the Supreme Court "refused to do so." ${ }^{\text {"95 }}$ Nonetheless, Kenrick informed Spalding that "We [the Catholic Church] have retained Attny Genl. Speed \& Reverdy Johnson on our side at very great expense. ${ }^{\text {896 }}$ Ultimately, the support of Reverdy Johnson — a Democrat and United States senator from Maryland—proved critical to the final ruling in the case. As historian Harold Hyman explained:

${ }^{890}$ Peter Richard Kenrick to Martin John Spalding, November 6, 1865, 34-M-17, AAB.

891 Ibid.

892 Ibid.

${ }^{893}$ White, 94.

${ }^{894}$ Peter Richard Kenrick to Martin John Spalding, January 6, 186[6], 34-M-10, AAB.

895 Ibid.

896 Ibid. 
Reverdy Johnson offered the final argument for Cummings. Missouri's constitution was not exempt from the national prohibition against ex post facto laws and bills of attainder. Treason had but one definition, and minimum standards for proof. Missouri's oath substituted nonjuring for a confession of treason, and automatically adjudged an unalterable penalty. Religious freedom was basic to the liberties of all Americans, and needed no Constitutional injunction against state infringement. ${ }^{897}$

On January 14, 1867, the Supreme Court decided the case in favor of Cummings, "declaring the ironclad oath to be unconstitutional." $" 898$ Undoubtedly, Cummings, Kenrick, Spalding, and other Catholic clergy in the Border States considered the verdict a triumph for religious liberty and an indication that the nation's highest court would uphold the concept of the separation of church and state. As one historian explained, "the Cummings case represent[ed] the final episode in the clerical struggle for neutrality and their liberties for which they had contended" during the war. ${ }^{899}$

\section{$\underline{\text { Conclusion }}$}

Members of the American Catholic hierarchy in the Border South opposed many of the policies enacted by the Union war effort, the Lincoln administration, and the Republican Party during the war. However, the degree of opposition depended on the individual beliefs and attitudes of the clergy as well as the context of the war within their dioceses. For example, Francis Patrick Kenrick proved one of the most loyal clerics from the Border States. Despite the sympathies of other priests in Baltimore, who refused to offer prayers for the Union, Kenrick supported the federal government from his pulpit. Nonetheless, he refused to tolerate the arrest of a Catholic priest and the closing of his church in Martinsburg, arguing that the actions violated the religious liberty of clergy.

\footnotetext{
${ }^{897}$ Hyman, 112.

${ }^{898}$ McArthur, 194.

${ }^{899}$ Ibid., 239.
} 
Martin John Spalding opposed the oath requirement in Kentucky, but the bishop complied with the law so that the Church's ministry could continue in the state. However, Spalding remained suspicious of federal encroachments into the affairs of the Church during the war. He opposed the conscription of clergy and the confiscation or destruction of Church property, informing Vatican officials about federal policies that he believed violated the separation of church. Finally, Peter Richard Kenrick proved one of the most confrontational Catholic leaders from the region. The archbishop blatantly opposed state and federal laws in Missouri and advised his clergy to do the same. In his opinion, the policies enacted by state officials and the Union Army represented such obvious violations of religious liberty that the prelate could not condone any compliance from the priests within his archdiocese.

In addition to the varied degrees of opposition among the Border State clergy, their private correspondences indicate that they interpreted much of the Civil War through a religious lens. Many of the Catholic bishops and priest considered the policies of martial law, the confiscation of Church property, conscription of clergy, and required loyalty oaths to be violations of the separation of church and state. Compared to the laity — who resisted many of the policies of the federal government based on political, legal, or economic motives - the clergy opposed many of the Union policies because they believed they violated religious liberty and constituted state encroachments into the religious sphere. Many of the clergy, especially Spalding, argued that the actions or policies that violated the separation of church and state evolved from a perceived antiCatholic sentiment associated with members of the Union war effort. Clearly, the religious contestation between Protestants and Catholics that occurred during the 
antebellum period shaped the ways in which Church clergy interpreted many of the policies and laws enacted during the war.

Finally, the study of Catholic clergy in the Border South underscored the problems associated with and the limitations of religious liberty and the separation of church and state during the Civil War. For leaders of a religious minority who experienced prejudice throughout the prewar period, protecting religious liberty and upholding the concept of the separation of church and state proved one of the clergy's foremost concerns during the war. This concern was contrasted by the principal objective of the federal government and members of the Union Army, who sought to maintain order in their military districts and suppress the rebellion as quickly as possible. As a result, policies enacted by the federal government to procure a victory were often interpreted by members of the American hierarchy to be the " "obvious infringement of religious liberty." "900 Such a contrast in perception underscores the complexity of concepts like the separation of church and state, particularly during times of civil war and in regions such as the Border South, where questions of loyalty remained a primary concern throughout the conflict.

${ }^{900}$ The Baltimore Catholic Mirror (September 9, 1865) quoted in Wimmer, 318. 


\section{CONCLUSION}

This thesis argues that Border State clergy interpreted the Civil War through a religious lens informed by their Catholic worldview. In doing so, prelates and priests from Missouri, Kentucky, and Maryland promoted and defended Catholicism, while simultaneously deriding Protestantism as the cause of secession, the war, and other national problems. Most important, the interconnectedness of the antislavery and antiCatholic movements of the antebellum period influenced how clergy viewed the conflict. Having experienced a period of intense nativism and religious prejudice during the $1840 \mathrm{~s}$ and 1850s, Catholics became critical of the Republican Party. They believed the party of Abraham Lincoln was anti-Catholic because of its association with the former Know Nothing Party and its connection to northern evangelical Protestantism. Shaped by the arguments of the nineteenth-century Catholic apologist movement, clergy denounced Republicans as anti-Catholic reformers who disregarded the law and threatened the order and stability of society. At the same time, the Church developed a symbiotic relationship with the Democratic Party. Lay Catholics voted for the Democrats because the party opposed the Know-Nothings (and later Republicans), vowed to protect the interests of immigrants, and denounced liberal reform movements such as temperance and abolitionism.

However, by 1860, most Border State Catholics supported the Stephen Douglas Democrats because the Illinois senator's platform of unionism, upholding the Constitution, and maintaining the status quo harmonized with the Church's tenets and 
principles. Prelates and priests in the region denounced both Lincoln and John C. Breckinridge because they believed that the Republicans and southern Democrats constituted regional variations of radical Protestant political parties. Denouncing both the secession movement and any military efforts to force the Confederate states back into the Union, Border State clergy endorsed the policy of neutrality. Neutrality complemented many of the clergy's religious teachings as well as their attempts to maintain an apolitical Church. Once fighting began in the Border States, clergy promoted peace and sought chaplains and women religious to minister to troops on both sides of the war. Furthermore, they maintained that Protestantism was the root cause of the conflict and argued that Catholicism offered a resolution to disunion and civil war. However, by the end of 1862, the clergy began to direct their invectives at northern Protestants and Republicans. Lincoln's 1863 Emancipation Proclamation signaled to clergy that the president had converted the war into an abolitionist crusade. Before Lincoln issued his executive order, clergy argued that radical Protestants - in both the North and the South—had led the nation to disunion. However, after January 1863, the Border State clergy directed most of their invectives at northern Protestants and members of the Archdiocese of Cincinnati who supported abolitionism and wartime emancipation. Lincoln's executive order incensed Border State clergy because they viewed it as a radical policy that would create more harm than good for the country and African Americans. The Church had developed a rationalization or justification for slavery based on Catholic teachings and Church history. Inspired by Kenrick's Theologia moralis, prelates and priests sought to adhere to the laws that protected slavery while also ensuring that Catholics remained moral and just masters. Furthermore, slavery complemented the 
clergy's corporate ideal of the economy because they viewed it as superior to the Republicans' free labor system. While clergy did not support the expansion of the institution, prelates and priests believed that, given the choice between their ideal form of slavery and an unrestricted capitalist society, the country's and the slaves' best interests lay in a corporate ideal of the economy that included slavery. Clergy also derided federal policies they perceived as infringements on their religious and civil liberties. Prelates and priests considered the confiscation and destruction of Church property, forced conscription of the religious, and required loyalty oaths for clergy to be federal actions that violated the separation of church and state, a concept the clergy valued for the protection of their religion in a Protestant-controlled country. Above all, many of the clergy argued that the violations of the separation of church and state during the war derived from the anti-Catholic sentiments of those who supported the Union war effort.

During the Civil War, Border State clergy compared their religious principles with those of Protestantism. Throughout the antebellum period, the Protestant majority had criticized Catholicism as a repressive religion, the antithesis to American values, and a threat to the future of the country. Catholics responded with their own apologist movement that defended their faith and attacked Protestantism. In the clergy's opinion, the Civil War constituted the greatest criticism of their religious adversaries because they believed that secession, the war, and the misery and death caused by the conflict resulted from Protestantism's divisiveness, wickedness, individualism, and fanaticism. The clergy concluded that if a majority of Americans had embraced Catholicism then the war could have been avoided and law, order, and morality preserved in society. 


\section{REFERENCES}

\section{$\underline{\text { Archival Sources }}$}

Associated Archives at St. Mary's Seminary and University (Baltimore, MD) Francis Patrick Kenrick Papers Martin John Spalding Papers

Kentucky Historical Society (Frankfort, KY) Jacob Ditzler Journal, 1860-1866 John L. Verdin Letter, 1864

Sisters of Loretto Archives (Nerinx, KY) Joseph P. Machebeuf Papers

University of Notre Dame Archives (Notre Dame, IN) Archdiocese of Baltimore Collection (CABA) Archdiocese of Cincinnati Records (CACI Archdiocese of Louisville Records (CDBL) Archdiocese of New Orleans Collection (CANO) Benedict Joseph Spalding Papers (CBJS)

\section{$\underline{\text { Published Primary Sources }}$}

Beecher, Lyman. A Plea for the West. Cincinnati, OH: Truman and Smith, 1835.

Carroll, Anna Ella. The Great American Battle: Or the Contest Between Christianity and Political Romanism. New York: Miller, Orton, \& Mulligan, 1856.

F. E. T., Editor. The Kenrick-Frenaye Correspondence: Letters Chiefly of Francis Patrick Kenrick and Marc Antony Frenaye, 1830-1862. Philadelphia, PA: Wickersham Publishing Company, 1920.

Fehrenbacher, Don E., Editor. Lincoln: Selected Speeches and Writings. New York: Vintage Books/The Library of America, 1992.

Kenrick, Peter Richard. The Validity of Anglican Ordinations and Anglican Claims to Apostolical Succession Examined. Second edition. Philadelphia, PA: Eugene Cummiskey, 1848. 
Mackey, Thomas C., Editor. A Documentary History of the American Civil War Era. Volume 2, Political Arguments. Knoxville: The University of Tennessee Press, 2013.

Rowan, Steven, Translator and Editor. Germans for a Free Missouri: Translations from the St. Louis Radical Press, 1857-1862. Columbia: University of Missouri Press, 1983.

Spalding, David, Editor. "Martin John Spalding's 'Dissertation on the American Civil War.'” The Catholic Historical Review 52 (April 1966): 6685.

Spalding, Martin John. D'Aubigné's "History of the Great Reformation in Germany and Switzerland" Reviewed. Baltimore, MD: John Murphy Co., 1844.

-------. General Evidences of Catholicity: Being the Substance of a Course of Lectures Lately Delivered in the Cathedral of St. Louis, Louisville. Louisville, KY: B. J. Webb and Brother, 1847.

------. Miscellanea: Comprising Reviews, Lectures, and Essays, on Historical, Theological, and Miscellaneous Subjects. Louisville, KY: Webb, Gill, \& Levering, 1855.

-------. Sketches of the Early Catholic Missions of Kentucky; From Their Commencement in 1787, to the Jubilee of 1826-7. Louisville, KY: B. J. Webb \& Brother, 1844.

-------. The History of the Protestant Reformation, in Germany and Switzerland: and in England, Ireland, Scotland, the Netherlands, France, and Northern Europe. Louisville, KY: Webb and Levering, 1860.

Turner, Justin G. and Linda Levitt Turner, Editors. Mary Todd Lincoln: Her Life and Letters. New York: Alfred A. Knopf, Inc., 1972.

Verot, Augustin. A Tract for the Times: Slavery \& Abolitionism, Being the Substance of a Sermon, Preached in the Church of St. Augustine, Florida, on the $4^{\text {th }}$ Day of January, 1861. New Orleans, LA: Catholic Propagator Office, 1861.

Zanca, Kenneth J., Editor. American Catholics and Slavery: 1789-1866, An Anthology of Primary Documents. Lanham, MD: University Press of America, 1994.

\section{$\underline{\text { Books }}$}

Adler, Jeffery S. Yankee Merchants and the Making of the Urban West: The Rise and Fall of Antebellum St. Louis. New York: Cambridge University Press, 1991. 
Anbinder, Tyler. Nativism and Slavery: The Northern Know Nothings and the Politics of the 1850s. New York: Oxford University Press, 1992.

Astor, Aaron. Rebels on the Border: Civil War, Emancipation, and the Reconstruction of Kentucky and Missouri. Baton Rouge: Louisiana State University Press, 2012.

Billington, Ray Allen. The Protestant Crusade, 1800-1860: A Study of the Origins of American Nativism. New York: Macmillan Company, 1938.

Blair, William A. With Malice Toward Some: Treason and Loyalty in the Civil War Era. Chapel Hill: The University of North Carolina Press, 2014.

Blied, Benjamin J. Catholics and the Civil War. Milwaukee: privately published, 1945.

Brokhage, Jospeh D. Francis Patrick Kenrick's Opinion on Slavery. Washington, DC: Catholic University of America, 1955.

Caravaglios, Maria. The American Catholic Church and the Negro Problem in the XVIIIXIX Centuries. Charleston, SC: Unterkoefler, 1974.

Carey, Patrick W. Catholics in America: A History. Westport, CT: Praeger, 2004.

Carwardine, Richard. Lincoln: A Life of Purpose and Power. New York: Alfred A. Knopf, 2006.

Crews, Clyde F. An American Holy Land: A History of the Archdiocese of Louisville. Wilmington, DE: Michael Glazier, Inc., 1987.

Curran, Charles E. The Origins of Moral Theology in the United States: Three Different Approaches. Washington, DC: Georgetown University Press, 1997.

Curran, Robert Emmett. Shaping American Catholicism: Maryland and New York, 18051915. Washington, DC: Catholic University of America Press, 2012.

DePalma, Margaret C. Dialogue on the Frontier: Catholic and Protestant Relations, 1793-1883. Kent, OH: The Kent State University Press, 2004.

Dichtl, John R. Frontiers of Faith: Brining Catholicism to the West in the Early Republic. Lexington: The University Press of Kentucky, 2008.

Dolan, Jay P. In Search of an American Catholicism: A History of Religion and Culture in Tension. New York: Oxford University Press, 2002.

-------. The American Catholic Experience: A History from Colonial Times to the Present. New York: Doubleday \& Company, 1985. 
Egerton, Douglas R. Year of Meteors: Stephen Douglas, Abraham Lincoln, and the Election that Brought on the Civil War. Second edition. New York: Bloomsbury Press, 2013.

Ellis, John Tracy. American Catholicism. Second Edition. Chicago: The University of Chicago Press, 1969.

Faherty, William Barnaby. Exile in Erin: A Confederate Chaplain's Story, The Life of Father John B. Bannon. Saint Louis: Missouri Historical Society Press, 2002.

-------. The St. Louis German Catholics. St. Louis, MO: Reedy Press of the University of Nebraska Press, 2004.

Fenton, Elizabeth. Religious Liberties: Anti-Catholicism and Liberal Democracy in Nineteenth-Century U.S. Literature and Culture. New York: Oxford University Press, 2011.

Fessenden, Tracy. Culture and Redemption: Religion, the Secular, and American Literature. Princeton, NJ: Princeton University Press, 2007.

Foner, Eric. Free Soil, Free Labor, Free Men: The Ideology of the Republican Party before the Civil War. Second Edition. New York: Oxford University Press, 1995.

-------. The Fiery Trial: Abraham Lincoln and American Slavery. New York: W. W. Norton, 2010.

Franchot, Jenny. Roads to Rome: The Antebellum Protestant Encounter with Catholicism. Oakland: University of California Press, 1994.

Freehling, William W. The South vs. The South: How Anti-Confederate Southerners Shaped the Course of the Civil War. New York: Oxford University Press, 2001.

-------. The Road to Disunion: Secessionists Triumphant, 1854-1861. New York: Oxford University Press, 2007.

Gannon, Michael. Rebel Bishop: Augustin Verot, Florida's Civil War Prelate. Gainesville: University Press of Florida, 1964.

Gerteis, Louis S. The Civil War in Missouri: A Military History. Columbia: University of Missouri Press, 2012.

Gjerde, Jon and S. Deborah King. Catholicism and the Shaping of Nineteenth-Century America. New York: Cambridge University Press, 2012. 
Gleeson, David T. The Green and the Gray: The Irish in the Confederate States of America. Chapel Hill: The University of North Carolina Press, 2013.

Goen, C. C. Broken Churches, Broken Nation: Denominational Schisms and the Coming of the American Civil War. Macon, GA: Mercer University Press, 1985.

Goldfield, David. America Aflame: How the Civil War Created a Nation. New York: Bloomsbury Press, 2011.

Griffin, Susan M. Anti-Catholicism and Nineteenth-Century Fiction. New York: Cambridge University Press, 2004.

Guelzo, Allen C. Lincoln's Emancipation Proclamation: The End of Slavery in America. New York: Simon \& Schuster, 2004.

Harlow, Luke E. Religion, Race, and the Making of Confederate Kentucky, 1830-1880. New York: Cambridge University Press, 2014.

Harris, William C. Lincoln and the Border States: Preserving the Union. Lawrence: University of Kansas Press, 2011.

Harrison, Lowell H. and James C. Klotter. A New History of Kentucky. Lexington: The University Press of Kentucky, 1997.

Hatch, Nathan O. The Democratization of American Christianity. New Haven, CT: Yale University Press, 1989.

Hennesey, James. American Catholics: A History of the Roman Catholic Community in the United States. New York: Oxford University Press, 1981.

Hernon, Jr., Joseph M. Celts, Catholics, and Copperheads: Ireland Views the American Civil War. Columbus: Ohio State University Press, 1968.

Hochgeschwender, Michael. Wahrheit, Einheit, Ordnung: Die Sklavenfrage und der americkanische Katholizismus, 1835-1870. Paderborn: Ferdinand Schöningen, 2006.

Honeck, Mischa. We Are the Revolutionists: German-Speaking Immigrants \& American Abolitionists after 1848. Athens: University of Georgia Press, 2011.

Howe, David Walker. What Hath God Wrought: The Transformation of America, 18151848. New York: Oxford University Press, 2007.

Hyman, Harold Melvin. Era of the Oath: Northern Loyalty Tests during the Civil War and Reconstruction. Philadelphia: University of Pennsylvania Press, 1954. 
Klement, Frank L. The Copperheads in the Middle West. Chicago: University of Chicago Press, 1960.

------. The Limits of Dissent: Clement L. Vallandigham and the Civil War. Lexington: The University Press of Kentucky, 1970.

Kurtz, William B. Excommunicated from the Union: How the Civil War Created a Separate Catholic America. New York: Fordham University Press, 2016.

Longley, Max. For the Union and the Catholic Church: Four Converts in the Civil War. Jefferson, NC: McFarland Publishing, 2015.

Marshall, Anne E. Creating a Confederate Kentucky: The Lost Cause and Civil War Memory in a Border State. Chapel Hill: The University of North Carolina Press, 2010.

Marty, Martin E. Pilgrims in Their Own Land: 500 Years of Religion in America. New York: Little, Brown and Company, 1984.

Masur, Louis P. Lincoln's Hundred Days: The Emancipation Proclamation and the War for the Union. Cambridge, MA: The Belknap Press of Harvard University Press, 2012.

Matthews, Gary R. More American than Southern: Kentucky, Slavery, and the War for an American Ideology, 1828-1861. Knoxville: The University of Tennessee Press, 2014.

McClintock, Russell. Lincoln and the Decision for War: The Northern Response to Secession. Chapel Hill: The University of North Carolina Press, 2008.

McGann, Agnes Geraldine. Nativism in Kentucky to 1860. Washington, DC: The Catholic University of America, 1944.

McGreevy, John T. Catholicism and American Freedom. New York: W. W. Norton and Company, 2003.

McPherson, James M. Battle Cry of Freedom: The Civil War Era. New York: Oxford University Press, 1988.

Miller, Randall M. and Harry S. Stout, Editors. Religion and the American Civil War. New York: Oxford University Press, 1998.

Miller, Randall M. and Jon L. Wakelyn, Editors. Catholics in the Old South. Macon, GA: Mercer University Press, 1983.

Miller, Robert J. Both Prayed to the Same God: Religion and Faith in the American Civil 
War. Lanham, MD: Lexington Books, 2007.

Murphy, Angela F. American Slavery, Irish Freedom: Abolition, Immigrant Citizenship, and the Transatlantic Movement for Irish Repeal. Baton Rouge: Louisiana State University Press, 2010.

Nash, Gary B. and Jean R. Soderlund. Freedom by Degrees: Emancipation in Pennsylvania and its Aftermath. New York: Oxford University Press, 1991.

Neely, Jr., Mark E. The Fate of Liberty: Abraham Lincoln and Civil Liberties. New York: Oxford University Press, 1991.

Noll, Mark A. The Civil War as a Theological Crisis. Chapel Hill: The University of North Carolina Press, 2006.

O'Shea, John J. The Two Kenricks: Baltimore and St. Louis. Philadelphia, PA: John J. McVey, 1904.

O’Toole, James M. The Faithful: A History of Catholics in America. Cambridge, MA: Belknap Press, 2008.

Panzer, Joel S. The Popes and Slavery. Staten Island, NY: Alba House, 1996.

Pasquier, Michael. Fathers on the Frontier: French Missionaries and the Roman Catholic Priesthood in the United States, 1789-1870. New York: Oxford University Press, 2010.

Phillips, Christopher. The Civil War in the Border South. Santa Barbara, CA: Praeger, 2013.

Pinheiro, John C. Missionaries of Republicanism: A Religious History of the MexicanAmerican War. New York: Oxford University Press, 2014.

Rable, George C. God's Almost Chosen People: A Religious History of the American Civil War. Chapel Hill: The University of North Carolina, 2010.

Rice, Madeleine Hooke. American Catholic Opinion in the Slave Controversy. New York: Columbia University Press, 1944.

Rothensteiner, John. History of the Archdiocese of St. Louis: In Its Various Stages of Development from A.D. 1673 to A.D. 1928. 2 volumes. St. Louis, MO: Blackwell Wielandly Co., 1928.

Samito, Christian G. Becoming American Under Fire: Irish Americans, African Americans, and the Politics of Citizenship during the Civil War Era. Ithaca, NY: Cornell University Press, 2009. 
Shattuck, Jr., Gardiner. A Shield and a Hiding Place: The Religious Life of the Civil War Armies. Macon, GA: Mercer University Press, 1987.

Shea, John Gilmary. History of the Catholic Church in the United States from the Fifth Provincial Council of Baltimore, 1843, to the Second Plenary Council of Baltimore, 1866. Rahway, NJ: The Mershon Company Press, 1892.

Silverman, John H. Lincoln and the Immigrant. Carbondale: Southern Illinois University Press, 2015.

Spalding, Thomas W. Martin John Spalding: American Churchman. Washington, DC: The Catholic University of America Press, 1973.

------. The Premier See: A History of the Archdiocese of Baltimore, 1789-1994. Baltimore, MD: The John Hopkins University Press, 1995.

Stern, Andrew Henry. Southern Crucifix, Southern Cross: Catholic-Protestant Relations in the Old South. Tuscaloosa: The University of Alabama Press, 2012.

Thomas, Hugh. The Slave Trade: The Story of the Atlantic Slave Trade, 1440-1870. New York: Simon \& Schuster, 1997.

Vorenberg, Michael. Final Freedom: The Civil War, the Abolition of Slavery, and the Thirteenth Amendment. New York: Cambridge University Press, 2001.

Wallace, W. Jason. Catholics, Slaveholders, and the Dilemma of American Evangelicalism,1835-1860. Notre Dame, IN: University of Notre Dame Press, 2010.

Warner, William. At Peace with All Their Neighbors: Catholics and Catholicism in the National Capital, 1787-1860. Washington, DC: Georgetown University Press, 1994.

Weber, Jennifer L. Copperheads: The Rise and Fall of Lincoln's Opponents in the North. New York: Oxford University Press, 2006.

Wesley, Timothy L. The Politics of Faith during the Civil War. Baton Rouge: Louisiana State University Press, 2013.

Woods, James M. A History of the Catholic Church in the American South. Gainesville: University Press of Florida, 2011.

Woodworth, Steven E. While God is Marching On: The Religious World of Civil War Soldiers. Lawrence: University of Kansas Press, 2001.

Zanca, Kenneth J. The Catholics and Mrs. Mary Surratt: How They Responded to the 
Trial and Execution of the Lincoln Conspirator. Lanham, MD: University Press of America, 2008.

Articles, Book Reviews, Book Chapters, Dissertations, and Theses

Alvarez, David J. "The Papacy in the Diplomacy of the American Civil War." Catholic Historical Review 69 (April 1983): 227-248.

Anderson, Kristen L. "German Americans, African Americans, and the Republican Party in St. Louis, 1865-1872." Journal of American Ethnical History 28 (Fall 2008): 34-51.

Boyd, John A. "Neutrality and Peace: Kentucky and the Secession Crisis of 1861." PhD dissertation, University of Kentucky, 1999.

Danver, Brian. "The Fight for the American Dream: Irish-Americans and the Civil War." MA thesis, Georgetown University, 2014.

George, Jr., Joseph. “'A Catholic Family Newspaper' Views the Lincoln Administration: John Mullaly’s Copperhead Weekly." Civil War History 24 (June 1978): 112132.

Gollar, C. Walker. "Catholic Slaves and Slaveholders in Kentucky." The Catholic Historical Review 84 (January 1998): 42-62.

-------. "Jesuit Education and Slavery in Kentucky, 1832-1868." Register of the Kentucky Historical Society 108 (Summer 2010): 213-249.

Heisser, David C. R. "Bishop Lynch's People: Slaveholding by a South Carolina Prelate." The South Carolina Historical Magazine 102 (July 2001): 238-262.

Hitchcock, James. "Race, Religion, and Rebellion: Hilary Tucker and the Civil War." The Catholic Historical Review 80 (July 1994): 497-517.

Kennedy, Philip Wayne. "Bishop M. J. Spalding and the Know-Nothing Movement in Kentucky." MA thesis, Marquette University, 1957.

Klement, Frank L. "Catholics as Copperheads during the Civil War." The Catholic Historical Review 80 (January 1994): 36-57.

Kurtz, William B. "Roman-Catholic Americans in the North and Border States during the Era of the American Civil War." PhD dissertation, University of Virginia, 2012.

-------. “This Most Unholy and Destructive War': Catholic Intellectuals and the Limits 
of Catholic Patriotism." In So Conceived and So Dedicated: Intellectual Life in the Civil-War Era North, edited by Lorien Foote and Kanisorn Wongsrichanalai. New York: Fordham University Press, 2015, 217-235.

LeBuffe, Leon A. "Tensions in American Catholicism, 1820-1870: An Intellectual History." PhD dissertation, The Catholic University of America, 1973.

Mach, Andrew. "“The Name of Freeman is Better Than Jesuit': Anti-Catholicism, Republican Ideology, and Cincinnati Political Culture, 1853-1854." Ohio Valley History 15 (Winter 2015): 3-21.

Mackey, Thomas C. "Not a Pariah, But a Keystone: Kentucky and Secession." In Sister States, Enemy States: The Civil War in Kentucky and Tennessee, edited by Kent T. Dollar, Larry H. Whiteaker, and W. Calvin Dickinson. Lexington: The University Press of Kentucky, 2009, 25-45.

McArthur, Marcus J. "Treason in the Pulpit: Disloyal Clergy in Civil War Missouri." PhD dissertation, Saint Louis University, 2012.

Mengel, Jennie Angell. “The Neutrality of Kentucky in 1861.” MA thesis, University of Louisville, 1925.

Mittlebeeler, Emmet V. "The Aftermath of Louisville's Bloody Monday Election Riot of 1855." Filson History Quarterly 66 (April 1992): 197-219.

Murphy, Robert Joseph. "The Catholic Church in the United States during the Civil War Period." Records of the American Catholic Historical Society 39 (December 1928): 271-346.

Noll, Mark A. Review of Wahrheit, Einheit, Ordnung: Die Sklavenfrage und der americkanische Katholizismus, 1835-1870, by Michael Hochgeschwender. Theologische Literaturzeitung 133 (2008): 834-836.

Paine, Christopher M. “'Kentucky Will Be the Last to Give Up the Union': Kentucky Politics, 1844-1861.” PhD dissertation, University of Kentucky, 1998.

Quinn, John F. “'Three Cheers for the Abolitionist Pope!': American Reaction to Gregory XVI's Condemnation of the Slave Trade, 1840-1860." The Catholic Historical Review 90 (January 2004): 67-93.

Ritter, Luke J. "Anti-Catholic America: Nativism and Religious Freedom in the Antebellum West." PhD dissertation, Saint Louis University, 2014.

Rockenbach, Stephen I. "A Border City at War: Louisville and the 1862 Confederate Invasion of Kentucky." Ohio Valley History 3 (Winter 2003): 35-52. 
Spalding, Thomas W. "The Maryland Catholic Diaspora." U. S. Catholic Historian 8 (Summer 1989): 163-171.

White, Mary Emmanuel. "Archbishop Peter Richard Kenrick and the Civil War.” MA thesis, Saint Louis University, 1948.

Wimmer, Judith Conrad. "American Catholic Interpretations of the Civil War." PhD dissertation, Drew University, 1979. 


\title{
CURRICULUM VITA
}

\author{
NAME: \\ Carl C. Creason \\ ADDRESS: $\quad 208$ Charlotte Drive \\ Clinton, KY 42031 \\ DOB: $\quad$ Union City, TN - July 9, 1987 \\ EDUCATION: $\quad$ M.A., United States History \\ University of Louisville \\ 2014-2016 \\ B.A., History/Social Studies Education \\ Murray State University \\ 2009-2011 \\ A.A., History \\ West Kentucky Community and Technical College \\ 2007-2009 \\ AWARDS: \\ Dean's Citation Award, University of Louisville (April 2016) \\ Best Graduate Paper, Regional Phi Alpha Theta Conference, \\ Dayton University (March 2016) \\ Department of History Graduate Fellowship, Northwestern \\ University (February 2016) \\ Graduate Student Spotlight, University of Louisville (January \\ 2016) \\ Department of History Research Scholarship, University of \\ Louisville (Fall 2015) \\ Graduate Network of Arts and Sciences Research Scholarship, \\ University of Louisville (Fall 2015) \\ Graduate Teaching Assistantship, Department of History, \\ University of Louisville (2014-2016)
}


PROFESSIONAL SOCIETIES:

Phi Alpha Theta

Society of Civil War Historians

Southern Historical Society

PUBLICATIONS: "Shedding Light on Kentucky’s Jackson Purchase Region during the Civil War." Ohio Valley History, Vol. 15, No. 1 (Spring 2015): 74-77.

"United, Yet Divided: An Analysis of Bishops Martin John Spalding and John Baptist Purcell during the Civil War Era." American Catholic Studies, Vol. 124, No. 2 (2013): 49-69.

"Christopher Ludwig." Immigrant Entrepreneurship: GermanAmerican Business Biographies, 1720 to the Present, Vol. 1, edited by Marianne S. Wokeck. German Historical Institute (October 2013).

"Hardening Hearts in Virginia: The Crown's Great Race Gamble." Patriots of the American Revolution, Vol. 5, No. 4 (July/August 2012): 20-24.

PRESENTATIONS: “The 'obvious infringement of religious liberty': Roman Catholic Understandings of the Separation of Church and State in the Civil War Border South.” 2016 Regional Phi Alpha Theta Conference at Dayton University (March 2016).

"Converted Confederate: Alfred Zeler Boyer and Loyalty in Kentucky during the Civil War." 2015 Ohio Valley History Conference at Eastern Kentucky University (October 2015).

"Broken Families, Severed Sisterhoods, Complicated Courtships: Women and Wartime Sympathies in Kentucky, 1861-1862.” 2015 Queen City Colloquium at the University of Cincinnati (April 2015).

"United, Yet Divided: An Analysis of Catholic Bishops Martin John Spalding and John Baptist Purcell during the American Civil War Era." 2013 Bluegrass Symposium at the University of Kentucky (February 2013).

"The 'Squirrel Hunting' of the Civil War: Confederate Sharpshooters and Federal High-Value Targets." SHUR (Symposium for History Undergraduate Research) at Mississippi State University (May 2011). 